Ph.D. Thesis

\title{
INVESTIGATION OF THE TRANSIENT RECEPTOR POTENTIAL VANILLOID 1 (TRPV1) ION CHANNEL
}

\author{
Zoltán Winter
}

Szeged

2013 


\author{
Ph.D. Thesis
}

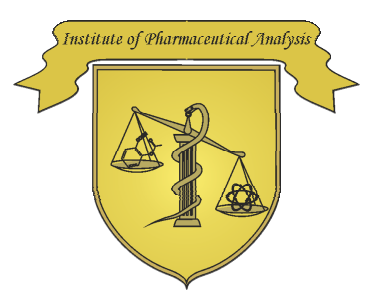

\title{
INVESTIGATION OF THE TRANSIENT RECEPTOR POTENTIAL VANILLOID 1 (TRPV1) ION CHANNEL
}

\author{
Zoltán Winter
}

\author{
Supervisors \\ Prof. György Dombi, Ph.D. C.Sc. \\ Gerda Szakonyi, Ph.D., Pharm.D. \\ Zoltán Oláh, Ph.D.
}

\begin{abstract}
University of Szeged
Faculty of Pharmacy

Institute of Pharmaceutical Analysis

Biological Research Centre of the Hungarian Academy of Sciences Institute of Biochemistry
\end{abstract}

Szeged

2013 


\section{Publications}

I. Pecze L, Pelsőczi P, Kecskés M, Winter Z, Papp A, Kaszás K, Letoha T, Vizler C, Oláh Z, Resiniferatoxin mediated ablation of TRPV1+ neurons removes TRPA1 as well, Can J Neurol Sci. 2009 Mar;36(2):234-41.

II. Pecze L, Winter Z, Jósvay K, Ötvös F, Kolozsi C, Vizler C, Budai D, Letoha T, Dombi G, Szakonyi G, Oláh Z., Divalent heavy metal cations block the TRPV1 Ca(2+) channel, Biol Trace Elem Res. 2013 Mar;151(3):451-61. doi: 10.1007/s12011-012-9570-y.

III. Winter Z, Buhala A, Ötvös F, Jósvay K, Vizler C, Dombi G, Szakonyi G, Oláh Z, Functionally important amino acid residues in the transient receptor potential vanilloid 1 (TRPV1) ion channel - an overview of the current mutational data, Mol Pain. 2013 Jun $22 ; 9(1): 30$.

(IF: 3.526)

\section{Presentations}

I. Winter Z, Jósvay K, A TRPV1 csatorna szerkezetének vizsgálata, 41. Membrán-Transzport Konferencia, Sümeg, May 2011.

II. Winter Z, Pecze L, Ötvös F, Jósvay K, Budai D, Vizler C, Letoha T, Szakonyi G, Dombi G, Oláh Z, Heavy metals especially cobalt inhibit TRPV1 channel, 3rd International Student Medical Congress in Košice, June 2011.

III. Winter Z, Nehézfém ionok hatása a TRPV1 ioncsatornára, X. Clauder Ottó Emlékverseny, Budapest, October 2011. 
IV. Winter Z, Nehézfémek hatása a vanilloid receptor müködésére, Életfolyamatok és szabályozásuk tudományos konferencia, Szeged, November 2011.

V. Winter Z, Pecze L, Ötvös F, Jósvay K, Kolozsi C, Budai D, Vizler C, Letoha T, Dombi G, Szakonyi G, Oláh Z, TRPV1 ioncsatorna vizsgálata nehézfém ionok jelenlétében, 42. Membrán-Transzport Konferencia, Sümeg, May 2012.

VI. Kolozsi C, Winter Z, Kusz E, Jósvay K, Vizler C, Dombi G, Oláh Z, Szakonyi G, A tranziens receptor potenciál vanilloid-1 (TRPV1) receptor szerepe a B16 melanóma növekedésében, 42. Membrán-Transzport Konferencia, Sümeg, May 2012.

VII. Buhala A, Jósvay K, Winter Z, Dombi G, Oláh Z, Szakonyi G, A humán TRPV1 receptor szerkezetének vizsgálata, 42. Membrán-Transzport Konferencia, Sümeg, May 2012.

VIII. Winter Z, Buhala A, Kalmár É, Structural analysis of human TRPV1 channel, 4th International Student Medical Congress in Košice, June 2012.

IX. Buhala A, Jósvay K, Winter Z, Pecze L, Kalmár É, Dombi G, Oláh Z, Szakonyi G, Structural analysis of the human TRPV1 channel, Hungarian Molecular Life Sciences, Siófok, April 2013. 


\section{Contents}

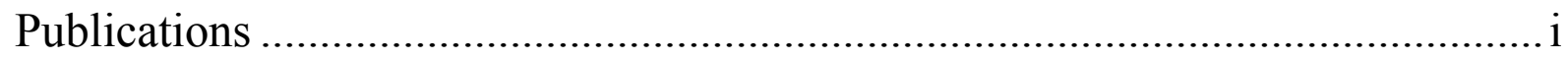

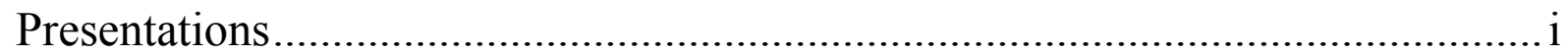

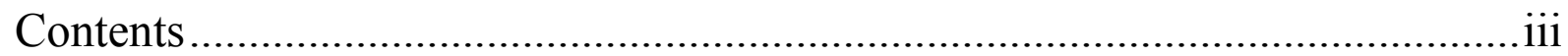

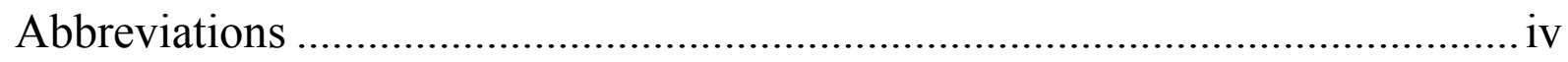

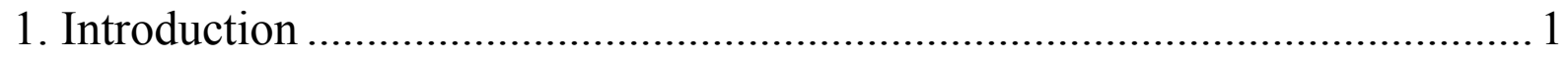

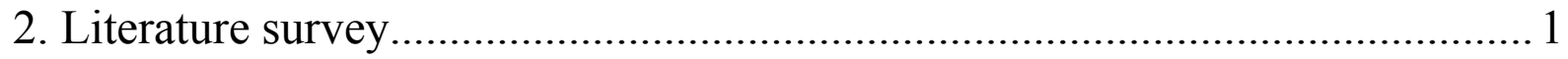

2. 1. Transient receptor potential channels........................................................ 1

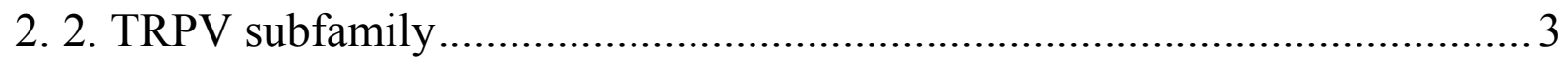

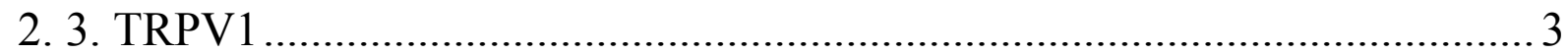

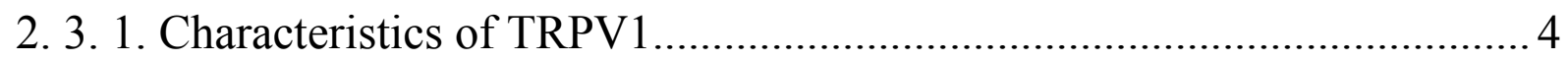

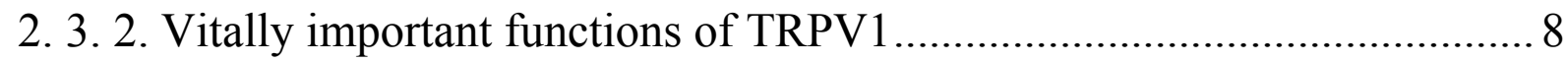

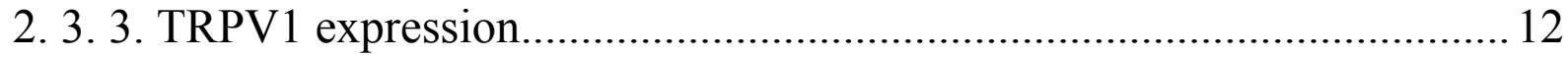

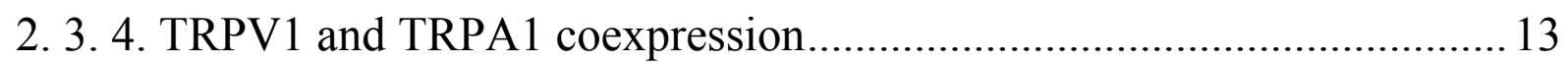

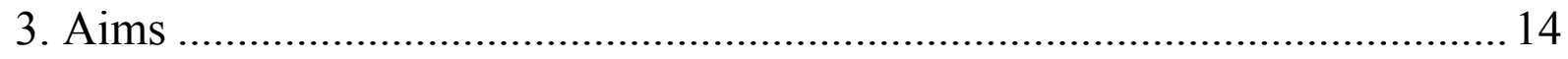

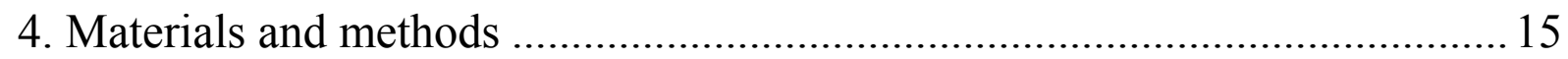

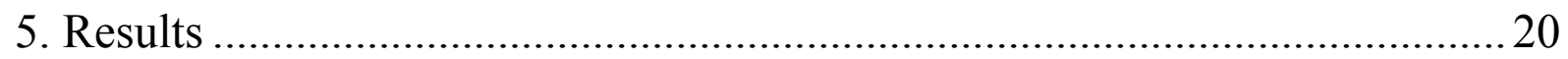

5. 1. The effects of RTX-mediated molecular neurosurgery ….........................20

5. 2. The effects of divalent heavy metal cations on the TRPV1 receptor .........23

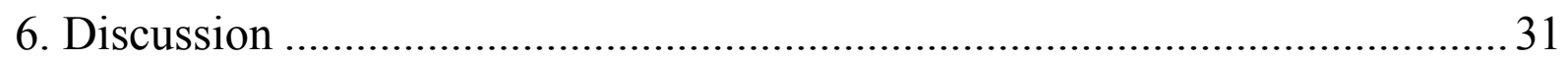

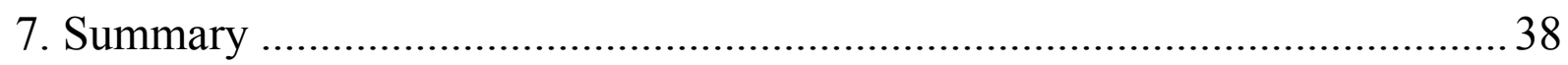

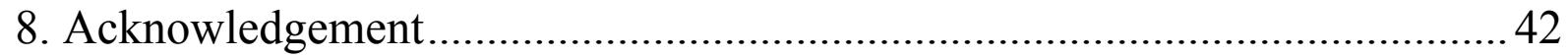

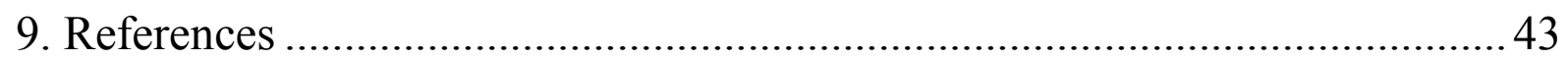

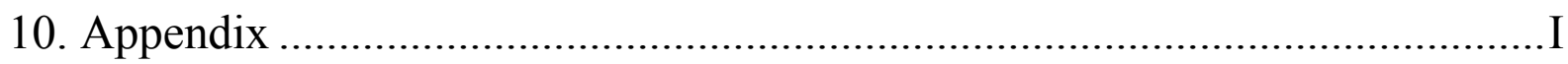




\section{Abbreviations}

AITC - allyl isothiocyanate

AMI - amitriptyline

ARD - ankyrin repeat domain

BCA - bicinchonic acid

CaM - calmodulin

CaMKII - $\mathrm{Ca}^{2+}$ calmodulin-dependent kinase II

CAPS - capsaicin

CapZ - capsazepine

CGRP - calcitonin gene related peptide

CNS - central nervous system

DMEM - Dulbecco's Modified Eagle Medium

DMSO - dimethyl sulfoxide

DRG - dorsal root ganglion

DTT - dithiothreitol

$\mathrm{EC}_{100}$ - maximum effective concentration

$\mathrm{EC}_{50}$ - half maximal effective concentration

$E_{\max }$ - maximal response of efficacy

HEPES - 4-(2-hydroxyethyl)-1piperazineethanesulfonic acid

I-RTX - iodoresiniferatoxin
$\mathrm{M}^{2+}$ - divalent metal cation

NADA - N-arachidonoyl dopamine

NGF - nerve growth factor

PBMC - peripheral blood mononuclear cell

PIP2 - phosphatidylinositol-4,5-

bisphosphate

PKA - protein kinase A

$\mathrm{PKC}$ - protein kinase $\mathrm{C}$

PNS - peripheral nervous system

RTX - resiniferatoxin

RuRed - ruthenium red

$\mathrm{R}_{4} \mathrm{~W}_{2}$ - hexapeptide RRRRWW-NH

S.D. - standard deviation(s)

TG - trigeminal ganglion

TGs - trigeminal ganglia

TM - transmembrane / transmembrane segment

TRPV1 - transient receptor potential vanilloid 1

VGCC - voltage-gated calcium channel

12-HPETE - 12-hydroperoxyeicosatetraenoic acid

2-APB - 2-aminoethoxydiphenyl borate 


\section{Introduction}

The goal of pharmaceutical research is to find solutions for intervention into disease- or pain-causing processes through the specific and effective manipulation of the target. Throughout history, mankind has strived to find ways to cure diseases or relieve pain. From chewing on willow bark to modern pharmaceuticals, the history of painkillers is long and filled with many technological advances. The development of small-molecule therapeutic agents for the treatment and prevention of diseases has also played a critical role in the practice of medicine for many years. Over the past half-century, a progression of drug discovery has been observed. Still, there were many diseases for which there were no effective therapeutic interventions. Thanks to the rapid advancements, synthetic organic chemistry offered the promise that, if a drug could be envisioned, it could be made. The rapid development of biology, providing more detailed information at the molecular level, had the possibility to catch up with synthetic chemistry.

Developing the therapeutic agents of the future will clearly involve the same basic science disciplines that have always been at the core of drug discovery: structural biology to provide information about the target biomacromolecules; chemistry to design and synthesize the drug candidates; and pharmacology to determine the effects of the interaction between drug and target.

The discovery of novel opportunities for therapeutic interventions requires a better understanding of the target, in our case, the structure-function relationship of the TRPV1 ion channel.

\section{Literature survey}

\section{1. Transient receptor potential channels}

The first TRP channel was discovered in 1969 by Cosens and Manning, who isolated a mutant photoreceptor from Drosophila melanogaster which caused the specimen to become temporally blind upon exposure to bright light $[4,5]$. TRP channels are one of the largest families of ion channels. The mammalian TRP superfamily, consisting of 28 TRP cation channels, can be subdivided into six subfamilies: the TRPC ("Canonical"), TRPV 
("Vanilloid"), TRPM (“Melastatin"), TRPP ("Polycystin”), TRPML ("MucoLipin") and TRPA ("Ankyrin") groups [6, 7] (Figure 1). All TRP channels are tetramers assembled with fourfold symmetry from the individual subunits containing six putative transmembrane

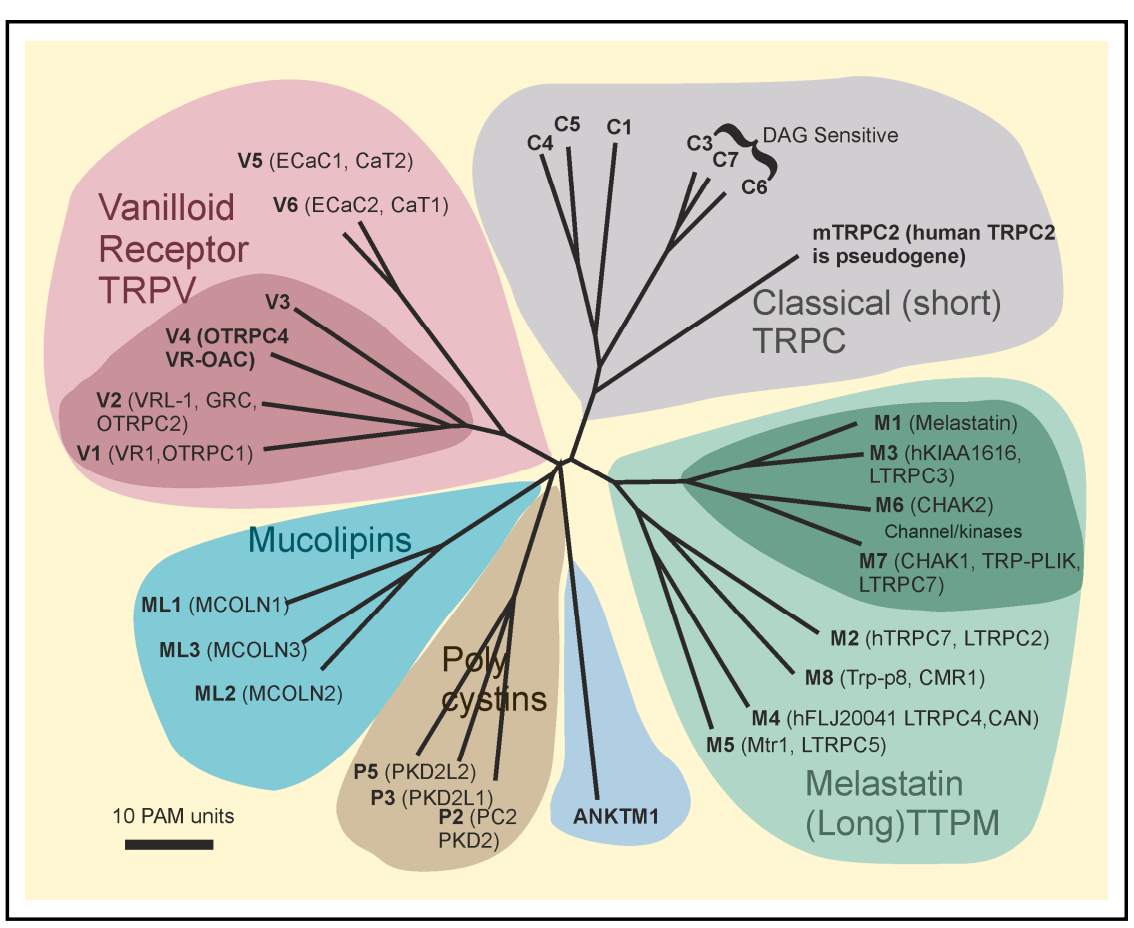

Figure 1: Mammalian TRP family tree

The evolutionary distance is shown by the total branch lengths in point accepted mutations (PAM) units, which is the mean number of substitutions per 100 residues [1]. segments (TMs). The region between the fifth and the sixth TMs, including a putative pore loop, forms the ion permeation pathway [8]. The amino and carboxyl $(\mathrm{N}-$ and $\mathrm{C}-)$ termini are located intracellularly and vary vastly in length and amino acid sequence. These cytoplasmic regions contain diverse wellrecognized domains and motifs that are likely to be involved in channel assembly, activation and regulation through protein-protein and/or protein-ligand interactions. Most TRP channels are cation-selective, and some are highly selective for $\mathrm{Ca}^{2+}$ or $\mathrm{Mg}^{2+}$ [7]. In accordance with their amino acid sequence diversity, TRP channels exhibit various activation and modulatory mechanisms, such as those involved in stimulation by G-proteincoupled receptors, extracellular and intracellular ligands (including $\mathrm{H}^{+}, \mathrm{Ca}^{2+}$ and $\mathrm{Mg}^{2+}$ ), phosphatidylinositol-4,5-bisphosphate (PIP2), temperature and mechanical stretch [9].

The accumulating evidence demonstrating that TRP channels are important components of several human diseases has created huge interest for these channels as novel potential drug targets. Comprehensive reviews have been published on the modulation and potential pharmaceutical application of TRP channels [2, 10-13]. 


\section{2. TRPV subfamily}

The TRPV family includes six mammalian ion channels, TRPV1-TRPV6, with a large Cand an even larger N-terminal cytoplasmatic domain containing ankyrin repeat domains (ARD) $[14,15]$. Ankyrin repeats, the 33-residue sequence motifs, are essential in channel function, ATP, PIP2 and calmodulin (CaM) binding [16] and protein-protein interactions $[17,18]$. They are present in many proteins, with functions including signalling, cytoskeleton integrity, transcription and cellular localization $[19,20]$.

As polymodal thermo- and chemosensitive channels, TRPV1-TRPV4 are non-selective for cations and modestly permeable to $\mathrm{Ca}^{2+}$. In contrast, TRPV5 and TRPV6 are the only highly $\mathrm{Ca}^{2+}$-selective channels in the TRP family, and both channels are tightly regulated by the intracellular $\mathrm{Ca}^{2+}$ concentration [12, 21, 22].

TRPV channels can be activated through a variety of mechanisms. TRPV1-TRPV4 can act as thermosensors at a molecular level. Interestingly, each of these channels has a different thermal threshold for activation. When expressed in transfected permanent cell lines (HEK293 and CHO cells) and in frog oocytes [7, 23, 24], TRPV2, TRPV1, TRPV3 and TRPV4 are activated at $52{ }^{\circ} \mathrm{C}, 43{ }^{\circ} \mathrm{C}, 33{ }^{\circ} \mathrm{C}$ and below $33{ }^{\circ} \mathrm{C}$, respectively. The TRPV family members, except for TRPV1, are insensitive to vanilloid compounds [7]. TRPV3 can be activated by essential oils from clove (eugenol), thyme (thymol) and oregano (carvacrol) [25]. Like TRPV1, TRPV3 is also activated by camphor [26]. TRPV4 can be activated by cell swelling caused by 5',6'-epoxyeicosatrienoic acid [27]. TRPV5 and TRPV6, originally named $\mathrm{ECaC}$ [28] and CAT1 [29], are $\mathrm{Ca}^{2+}$ entry channels responsible for $\mathrm{Ca}^{2+}$ absorption in the kidney and intestine, respectively.

\subsection{TRPV1}

In 1997, the breakthrough work of Michael Caterina and colleagues in the field of somatic sensory biology and pain research led to the cloning of the vanilloid (capsaicin) receptor, TRPV1 [30]. The cloning of TRPV1 proved to be a significant step in the understanding of the molecular mechanisms that underlie the transduction of noxious thermal and chemical stimuli by sensory neurons [2]. 


\section{3. 1. Characteristics of TRPV1}

As a TRPV subfamily member, TRPV1 can be characterized by some key properties that are common among the members of the family. It is built from four individual subunits containing six TMs [31], and it is believed to exist as a homo- or heteromeric complex form [30-32]. TRPV1 has a hydrophobic stretch between TM5 and TM6 forming the pore- and an ion selectivity filter region (Figure 2).

The TRPV1 receptor is a non-selective ligand-gated cation channel with a ninefold higher permeability for $\mathrm{Ca}^{2+}$ than for $\mathrm{Na}^{+}$. It is an integrator of a wide variety of exogenous and endogenous physical and chemical stimuli, including capsaicin (CAPS), noxious heat $\left(>43^{\circ} \mathrm{C}\right)$ and protons $(\mathrm{pH}<5.2)$. Strictly speaking, CAPS and its biological analogues isolated from plants and animals are essentially sensitizers, because they act by lowering the thermal

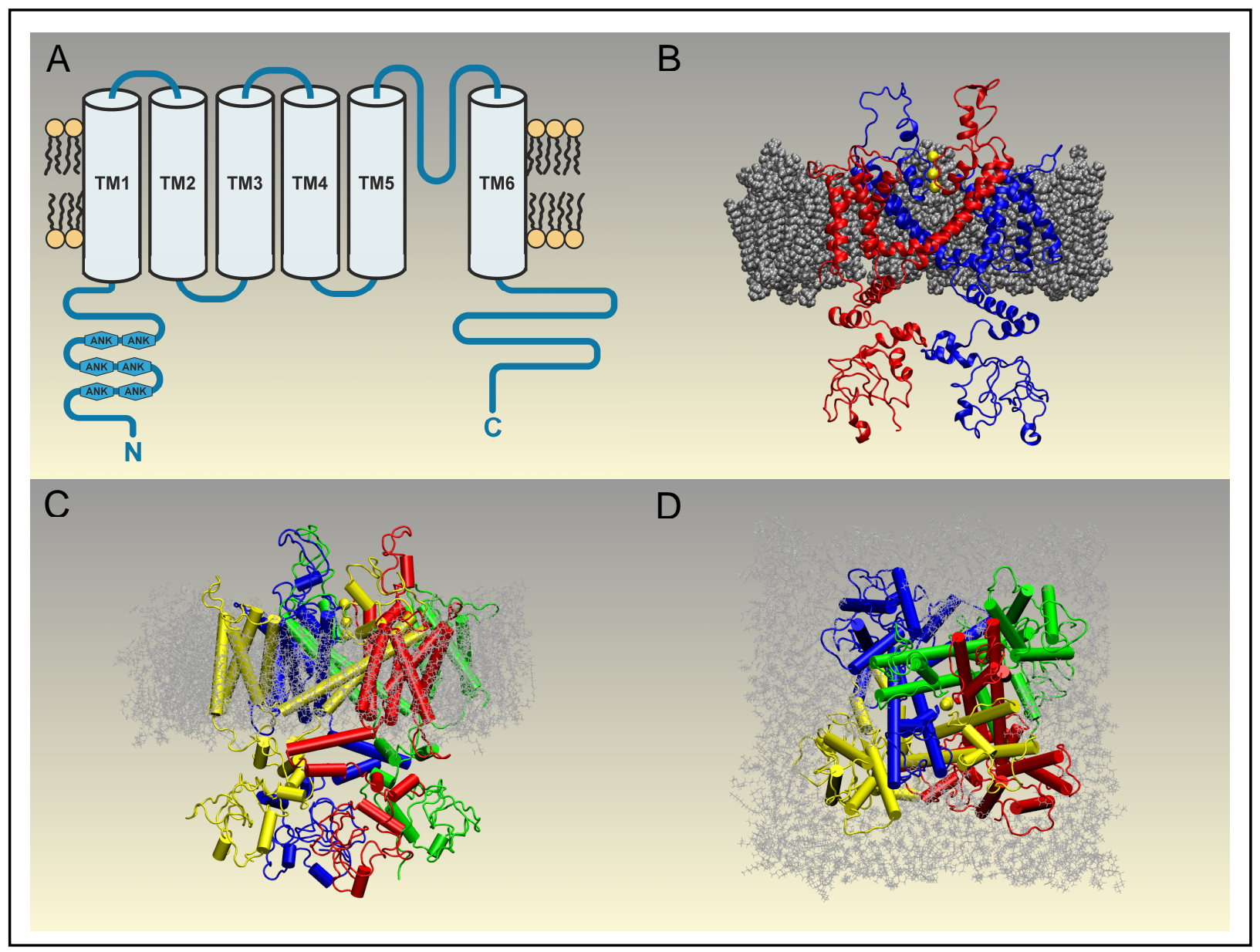

Figure 2: Putative structure of the TRPV1 receptor

A - Schematic structure of a TRPV1 monomer based on the figure of Szállási et al. [2]. B - Homology model structure of two TRPV1 monomers facing each other. C-Homology model structure of the tetrameric TRPV1, side view. D - Homology model structure of the tetrameric TRPV1, top view The figure is based on the PDB file of Fernández-Ballester and Ferrer-Montiel [3]. 
"physiological" activation threshold of TRPV1. Nevertheless, because these compounds bind directly to TRPV1, they are conveniently considered as direct activators, in contrast with compounds that do not bind TRPV1 and affect its functioning indirectly, which are referred to as sensitizers [33]. Besides CAPS, many complex amphiphilic molecules have been shown to activate or inhibit TRPV1. These include polyring compounds such as resiniferatoxin (RTX).

RTX, a highly irritant diterpene related to the phorbol esters [34], the most potent natural diterpene agonist of TRPV1, is present in latexes of various Euphorbia species, such as E. resinifera, E. poissoni and E. unispina [35]. Bioassays rank RTX as a 3-4 orders of magnitude more potent agonist of TRPV1 than CAPS. Species-specific differences in RTX potency have also been described, e.g., RTX is a more potent agonist on rTRPV1 than its human ortholog (hTRPV1) [36, 37].

Further molecules with similar structures, such as quinazolinone [38], evodiamine [39] and 17- $\beta$-estradiol [40], as well as molecules with long acyl and amide chains, such as anandamide [41-47], olvanil and omega-3 polyunsaturated fatty acids, can also activate the channel [48]. Other natural TRPV1 agonists are 12-hydroperoxyeicosatetraenoic acid (12-HPETE) and N-arachidonoyl dopamine (NADA) [44, 49-51]. Piperine from black pepper, eugenol from cloves and zingerone from ginger have also been shown to activate TRPV1 $[52,53]$. Additionally, gingerols, present in raw ginger, and shogaols, which are dehydration products of gingerols present in steamed ginger, both of which possess a vanillyl moiety, also activate TRPV1 [37, 47, 54, 55]. Since both CAPS and its analogues are lipophilic, they are able to cross the cell membrane and act on binding sites present on the intracellular surface of TRPV1 [56]. TRPV1 can also be activated by 2-aminoethoxydiphenyl borate (2-APB). 2-APB inhibits both IP3 receptors and the majority of TRP channels, though at higher concentrations it activates TRPV1, TRPV2 and TRPV3 [13, 57]. Allicin, one of the constituents of garlic, is also able to activate both TRPA1 and TRPV1 [58, 59]. Stimuli are detected and transduced through opening of the ion channel, which results in the entry of cations such as $\mathrm{Ca}^{2+}$ and $\mathrm{Na}^{+}$to the neuron [30]. With regard to its uniqueness in its diverse operational features, which differ from the classical, more restrained proteins of voltage-gated and ligand-gated channels, as well as from the G-protein-coupled receptors, TRPV1 was dubbed a "multisteric nocisensor" in the recent review paper by Szolcsányi and Sándor [60]. 
The inorganic dye Ruthenium Red (RuRed), is used in histology to stain aldehyde-fixed mucopolysaccharides. Long before the cloning of TRPV1, RuRed was demonstrated to be able to inhibit CAPS-induced responses in sensory neurons [61]. Later it was shown that RuRed is a non-competitive antagonist not only for TRPV1, but for most other TRP channels, functioning as a pore blocker [33]. The first competitive antagonist identified for TRPV1 was the CAPS analogue capsazepine (CapZ). CapZ is a relative potent antagonist on hTRPV1, but demonstrated much less potency on rTRPV1 [62, 63], illustrating the differences between species, a feature common for many TRPV1 antagonists. Since the discovery of CapZ, the number of TRPV1 patents has exceeded 1,000. Most of these antagonists show high affinity to TRPV1 and are competitive antagonists, binding to the same site as CAPS, and many of them have also demonstrated in vivo effects in various pain models [64]. The halogenated version of RTX, iodoresiniferatoxin (I-RTX) has been identified as a high-affinity antagonist of the TRPV1 channel and, similarly to RTX, it exerts different potency on hTRPV1 and rTRPV1 [65]. $\mathrm{R}_{4} \mathrm{~W}_{2}$, a small positively charged hexapeptide, was identified to be a noncompetitive antagonist blocker of recombinant TRPV1 channels expressed in Xenopus oocytes [66], blocking CAPS-operated ionic currents with micromolar efficacy in a weakly voltage-dependent manner. $\mathrm{R}_{4} \mathrm{~W}_{2}$ was later found to be a competitive antagonist of TRPV1 also in primary cultures of adult rat dorsal root ganglion neurons (DRGs) [67].

Besides its involvement in pain sensation, TRPV1 displays a low level of activity at normal body temperature [68, 69]. Constitutive activity of TRPV1 is essential for regulation of body temperature, as evidenced by high fever as an adverse side-effect of many TRPV1 blockers during clinical trials for their efficacy in the management or prophylaxis of pain $[70,71]$. Moreover, at room temperature $\left(24^{\circ} \mathrm{C}\right)$ and $\mathrm{pH} 7.3$, TRPV1 behaves as a voltagegated outwardly rectifying channel, since it can be activated, in the absence of any agonist, by depolarizing voltages $(>+60 \mathrm{mV})$ [72].

One striking feature of TRPV1 is that the receptor can be sensitized and desensitized. This fact suggests that the TRPV1 function is subject to extensive modulation, which has significant implications for the involvement of TRPV1 in physiological and pathophysiological conditions. Some inflammatory mediators in damaged tissues, including growth factors, neurotransmitters, peptides or small proteins, lipids, chemokines and cytokines, sensitize TRPV1 to its agonists [73]. Even in concentrations that fail to activate a 
current, CAPS can sensitize TRPV1 channels to protons and heat. Similarly, protons can sensitize TRPV1 channels to CAPS and heat $[74,75]$. The elevation of temperature or local acidity can in principle augment the efficacies of partial agonists, transforming them from weakly or non-pain-producing ligands into noxious chemicals [76, 77]. Whereas protons sensitize TRPV1 directly, most of the mediators work through receptor pathways, which include receptor tyrosine kinases and G-protein-coupled receptors. It has been reported that phosphorylation by protein kinase A (PKA) [78-80] and protein kinase C (PKC) can sensitize TRPV1 to CAPS, protons or heat [49, 74, 81-84]. The phosphorylation of TRPV1 by PKC acts to potentiate CAPS- or proton-evoked responses and reduces the temperature threshold for TRPV1 activation. Others have suggested that isoforms of $\mathrm{PKC} \alpha$ [85] or $\mathrm{PKC} \mu$ [86] are responsible for the effects described above. Protein kinase $\mathrm{D} / \mathrm{PKC} \mu$ is a member of the protein kinase D serine/threonine kinase family that exhibits structural, enzymological and regulatory features distinct from those of the PKCs, with which they are related. TRPV1 can also be phosphorylated by $\mathrm{Ca}^{2+}$ calmodulin-dependent kinase II (CaMKII) [87], or Src kinase [88], whilst the phosphatase calcineurin produces desensitization of the TRPV1 receptor [89]. TRPV1 undergoes two types of desensitization on activation by CAPS or protons: acute (short-term) desensitization and tachyphylaxis or loss of sensitivity to repeated stimulations $[16,90]$. Physiologically, TRPV1 desensitization can lead to the adaptation of peripheral neurons to pain perception. The regulatory lipid PIP2 is a putative intracellular modulator of TRPV1, although there is some debate as to whether it sensitizes or desensitizes the channel. Mutations in a C-terminal cytosolic region of TRPV1 indicate an inhibitory role for PIP2 [91]. However, others have found that PIP2 sensitizes TRPV1 and that depletion leads to desensitization [16, 92-95]. Another important membrane lipid in terms of TRPV1 activity is cholesterol. Cholesterol is a major component of plasma membranes and is enriched in lipid rafts. It has been shown to modify the function of many classes of ion channels [96]. Cholesterol can modify channel activity indirectly by altering the physical properties of the surrounding lipid bilayer, and the highly ordered lipid rafts can serve as organizing centers for many signalling processes [97]. In recent years, compelling evidence has emerged of a specific interaction between cholesterol and several channels [96, 98, 99]. A supporting role of sphingomyelin and gangliosides has also been demonstrated [100]. Sántha et al. demonstrated that inhibition of neuronal ganglioside synthesis by inhibition of 
glucosylceramide synthase reversibly decreased the CAPS-induced activation and TRPV1 expression of cultured DRG neurons, apparently leaving other markers of nociceptive neurons, such as calcitonin gene related peptide (CGRP) and IB4, unaffected [101]. Intracellular ATP can also sensitize TRPV1.

TRPV1 binds and is modulated by $\mathrm{Ca}^{2+} / \mathrm{CaM}$, a ubiquitous $\mathrm{Ca}^{2+}$ sensor $[102,103]$. An increase in intracellular $\mathrm{Ca}^{2+}$ concentration causes TRPV1 desensitization, and CaM plays a role in mediating this effect [102-104]. CaM interacts in vitro with isolated peptides from the TRPV1 N-terminal region in a $\mathrm{Ca}^{2+}$-dependent manner [103], and also binds to the TRPV1 C-terminal region in a $\mathrm{Ca}^{2+}$-independent manner [102]. The response of TRPV1 to heat can be modified by tyrosine kinases or G-protein-coupled receptors. Channel activation can occur even at normal body temperatures [74, 83, 105]. Reducing agents such as dithiothreitol (DTT) strongly increase the thermally induced activity of the TRPV1 channel. Moreover, the oxidizing agents diamide and chloramine- $\mathrm{T}$ facilitate thermally induced TRPV1-mediated currents [106]. Alkylating agents, such as N-ethylmaleimide, strongly and irreversibly affect heat-evoked responses from TRPV1, lowering the thermal activation threshold in a DTT-dependent manner [106]. It follows from these data that TRPV1 is targeted by redox-active substances that directly modulate the channel activity, and that channel potentiation may occur under altered redox states in a tissue, e.g., during ischaemia and/or inflammation, presumably leading to hyperalgesia.

Inflammatory agents such as bradykinin, serotonin, histamine or prostaglandins can further stimulate TRPV1 activity, either by PKC-dependent pathways [105, 107, 108], by releasing the channel from PIP2-dependent inhibition [91, 109], by a PKA-mediated recovery from inactivation [110], or by the formation of 12-HPETE [74, 111].

\section{3. 2. Vitally important functions of TRPV1}

The role of the TRP channels in pain and neurogenic inflammation have been very well covered by previous authors (e.g. [112-115]), reflecting the enormity of the role that these channels play in sensory nerve function at both central and peripheral levels [116]. Thus, TRPV1 plays a key role in the development of the burning pain sensation associated with acute exposure to heat or CAPS, and with inflammation in peripheral tissues $[30,87]$. The receptor seems to play an important role in certain chronic pain conditions, such as 
neuropathic pain, osteoarthritis, bone cancer pain, inflammatory bowel disease and migraine $[2,117,118]$.

Its involvement in these painful disorders, TRPV1 enables a new way of painkilling in certain otherwise intractable pain conditions. RTX, being an ultra-potent TRPV1 agonist, can induce $\mathrm{Ca}^{2+}$-cytotoxicity and eventually ablates these neurons by rapid necrosis, followed by removal of the cell debris [76, 119-121]. Exploitation of the $\mathrm{Ca}^{2+}$-excytotoxic potential of RTX has been proposed for pain management, through its use as an ablative agent specific for TRPV1-expressing cells. In vivo RTX treatment eliminates TRPV1+ nociceptors in the peripheral nervous system (PNS) while bystander neurons and their functions are spared $[76,122]$. Indeed, determination of specificity in vitro and in vivo in different animal models and human DRG cultures validated RTX as a "nano-scalpel" capable of "molecular neurosurgery" of specific inflammatory pain cells without affecting the other functionalities of the PNS and central nervous system (CNS) [76, 119, 121]. "RTX to treat severe pain associated with advanced cancer" is currently undergoing Phase II clinical trials [123].

TRPV1's role in the CNS is known to involve pain processing and modulation, neurogenesis [124] and thermoregulation [125], amongst others, but is currently less well understood.

Jancsó and Wollemann [126] have reported that CAPS stimulates adenylate cyclase activity in the rat cerebral cortex in vitro. Furthermore, direct injection of CAPS into the preoptic area of the anterior hypothalamus [125] or intracerebroventricular region [127] of the rat brain causes hypothermia, suggesting a role for this channel in thermoregulation. Similarly, systemic administration of TRPV1 antagonists such as AMG517 [69], AMG0347 [128] and A-425619 [129] causes an increase in body temperature within approximately 1 hour of treatment [116]. However, antagonist-induced hyperthermia may not be mediated by hypothalamic TRPV1 as peripherally-restricted antagonists still have the capacity to cause an increase in body temperature [130].

Within the periphery, recent evidence has located TRPV1 on a variety of non-neuronal tissues (for more details, see Table 2 in the paper of Fernandes et al. [116]). Although TRPV1 channel expression has been demonstrated in a wide variety of tissues, evidence of functionality has not yet been revealed for all of them. 
One of the first cell types in which functionality was identified was the epidermal keratinocytes. Inoue et al. [131] demonstrated that both CAPS and acidification produced elevations in the intracellular $\mathrm{Ca}^{2+}$ concentration in cultured human epidermal keratinocytes that could be inhibited by the TRPV1 antagonist, CapZ [116]. Similarly, treatment of human skin fibroblasts with CAPS induced significant changes in the membrane current and the intracellular $\mathrm{Ca}^{2+}$ level that were antagonized by CapZ [132]. It is therefore clear that TRPV1 is expressed and functional away from sensory nerves.

Physiological or pathophysiological effects of non-neuronal TRPV1 have been implicated in inflammation, infection and immunity, the cardiovascular system and conditions such as obesity [116].

A physiological/pathophysiological role for non-neuronal TRPV1 is perhaps nowhere more apparent than in the case of inflammation, infection and immunity. Although the effects of these TRPV1 channels are non-neuronal, it is evident that they may well impact indirectly upon pain and/or neurogenic inflammation [116]. Keratinocytes functionally express TRPV1. These cells play an important role in maintaining the integrity of the immune response in skin as well as stimulating cutaneous inflammation via prostanoid and cytokine release [133]. TRPV1 activation by CAPS causes an increase in COX-2 expression in human keratinocytes, with a concomitant increase in $\mathrm{PGE}_{2}$ levels in vitro [134]. An increase in IL-8 is also observed [134] Stimulation of inflammatory mediator release by TRPV1 agonists from keratinocytes could well have a significant effect upon sensory nerves that have a high density in the skin [116].

However, there is accumulating evidence that TRPV1 has functional roles apart from sensory nerve activity [116]. Besides keratinocytes, peripheral blood mononuclear cells (PBMCs) are also directly affected by TRPV1 activation. For example, PBMCs undergo apoptosis when stimulated with CAPS or RTX, an effect that is reversed by the TRPV1 antagonist AM630 [135]. There are various other cells involved in immunity that respond to TRPV1 and TRPA1 activation, including bone marrow-derived dendritic cells, where CAPS leads to dendritic cell maturation and an increase in antigen presentation [136].

TRPV1 is expressed, functional and active within cells relevant to inflammation, infection and immunity. It is clear from the studies that TRPV1 plays at least a paradoxical role in inflammation in vivo, for example, exacerbating inflammation in arthritis and yet in 
experimentally induced sepsis, TRPV1-null mice demonstrate elevated levels of pathological markers in comparison with wild-type mice [117]. It cannot be ruled out that this is due to differing effects of neuronal and non-neuronal TRPV1 channels [116].

TRPV1 have been shown to control vascular responses either by the well-established neurogenic response that is mediated by sensory nerves [137] or via a direct effect on vascular tissue $[138,139]$. However, the non-neuronal mechanisms involved in mediating vasodilatation and edema formation following TRPV1 activation in vivo are unclear. TRPV1 on endothelial cells has been shown to regulate the expression and secretion of endothelial cell-derived calcitonin gene-related peptide (CGRP), which affords protective effects on endothelial cells [140]. Furthermore, CGRP is a potent vasodilator [141], and may therefore impact upon blood pressure. Indeed, TRPV1 activation on sensory nerves also causes CGRP release, leading to a profound decrease in vascular tone [142]. On the other hand, TRPV1 expressed on vascular smooth muscle appears to cause vasoconstriction [139, 143, 144]. It has also been suggested that CAPS has biphasic effects on the vasculature: at lower concentrations, CAPS (up to $10 \mathrm{nM}$ ) evokes vasodilation in the skin due to sensory nerve activation, whereas higher concentrations $(0.1-1 \mathrm{mM})$ elicit substantial constrictions in the skeletal muscle arterioles, due to non-neuronal TRPV1 stimulation [139]. It is unclear whether this difference is due to receptor sensitivity or a difference in TRPV1 receptor density in the two tissues. A similar biphasic effect of CAPS has been demonstrated also in the meningeal blood vessels [145]. TRPV1 may also play a role in vascular responses during chronic hypoxia, where upregulation of the TRPV1 gene and protein is observed [146]. Chronic hypoxia has been shown to enhance the ability of human pulmonary artery smooth muscle cells to proliferate and to increase resting levels of cytosolic $\mathrm{Ca}^{2+}$ and capacitative $\mathrm{Ca}^{2+}$ entry with both effects being inhibited in a dose-dependent manner by the TRPV1 antagonist, CapZ [146]. These results suggest that TRPV1 on smooth muscle may be a critical pathway or mediator in chronic hypoxia-induced vascular changes [116].

Obesity is one of the most significant health issues in western society, due to the morbidity associated with this condition, which is increasing in prevalence. Obesity is induced by the hypertrophy of adipocytes and the recruitment of new adipocytes from precursor cells. These processes are dependent on the regulation of adipocyte differentiation. CAPS has been shown to inhibit adipocyte differentiation in vitro by activation of 
AMP-activated protein kinase [147]. Furthermore, Hsu and Yen [148] have shown that treatment of preadipocytes with CAPS decreases the number of normal adipocytes and increases the number of early apoptotic and late apoptotic cells in a dose-dependent manner. Thus, the overall effect of TRPV1 modulation in obesity is stark. Both animal [149] and human [150] data have indicated that the consumption of CAPS- or non-pungent capsiatecontaining foods is correlated with a reduced incidence of obesity. Similarly, oral administration of CAPS alone also suppresses body fat accumulation in mice [150], and dietary CAPS can reduce obesity-induced insulin resistance and hepatic steatosis in mice fed a high fat diet $[116,151]$.

In recent years, a role for TRPV1 in thermoregulation has also been identified, which may be due, at least in part, to changes in thermogenesis (for reviews, see [68, 152, 153]). For many years, CAPS has been known to cause a centrally mediated hypothermia in mice [125]. In contrast, its intragastric administration enhances thermogenesis and heat diffusion [154]. Similarly, the jejunal administration of non-pungent CAPS analogues has been shown to increase energy expenditure via the direct activation of TRPV1 located on intestinal extrinsic nerves [155]. Interestingly, some TRPV1 antagonists cause hyperthermia, associated with increased thermogenesis [129] through a peripheral mechanism [130], whilst TRPV1 gene knockdown does not affect body temperature in mice [156]. and TRPV1 knockout mice exhibit a normal basal body temperature [116, 128].

TRPV1 in the alimentary tract has also been implicated in metabolism, hair growth regulation [157] and the development of cancer [158].

Consequently, control of the TRPV1 function may have the potential to provide exciting opportunities for therapeutic interventions. Its known functions in both health and disease have been continuously expanding, promoting an improved understanding of TRPV1.

\section{3. 3. TRPV1 expression}

TRPV1 channels are mainly expressed on primary sensory neurones. They have been detected in key areas of the pain transduction pathway: on terminals of small-to-mediumdiameter nociceptors, such as peptidergic and non-peptidergic $\mathrm{C}$ fibers, some $\mathrm{A} \delta$ fibers $[30,75]$; in skin nerve endings, DRGs, nodose ganglia, trigeminal ganglia (TGs) of the PNS, as well as laminae I and II [75] of the dorsal horn of the spinal cord. Projections may also 
extend into laminae $\mathrm{V}$ and $\mathrm{X}$ [75]. Moreover, TRPV1 has been found in different brain regions, such as in the dopaminergic neurons of the substantia nigra, the hippocampal pyramidal neurons, the hypothalamic neurons, neurons in the locus coeruleus, and in various layers of the cortex $[27,159,160]$. The channel is present to a lesser extent in the hippocampus, cortex, olfactory bulb and cerebellum in the CNS [46, 161]. However, more recently, the use of TRPV1 reporter mice has revolutionized the study of TRPV1 expression, and it has been suggested that the expression of this receptor is minimal within a few discrete brain regions, most obviously in the vicinity of the caudal hypothalamus [116, 144].

TRPV1 is additionally expressed in discrete spots in the plasma membrane and cytosol of different non-neuronal cells such as the endothelium, immune cells (lymphocytes, dendritic cells and mast cells), keratinocytes, smooth muscle cells and urothelium, thymocytes and macrophages, some of which are known to be involved in inflammation [158]. An increased level of TRPV1 expression has been demonstrated in the sensory fibers of patients with an inflamed oesophagus (gastro-oesophageal reflex disease) or an inflamed bowel (both ulcerative colitis and Crohn's disease), or with chronic breast tenderness and pain [162]. There is likewise an increased TRPV1 expression in the sensory fibers of patients with rectal hypersensitivity and fecal urgency, and this increase is directly correlated with the degree of thermal and mechanical sensitivity [163].

\section{3. 4. TRPV1 and TRPA1 coexpression}

There have been debates about whether TRPV1 can [164-166] or can not [167-169] be activated by allyl isothiocyanate (AITC), an agonist of TRPA1. Previous to discovery of TRPV1 and TRPA1, it was routine to evaluate the pharmacological effects of vanilloids by mustard oil test. Since both TRPV1 and TRPA1 can evoke sterile inflammation, visualized by Evans Blue extravasation $[119,170]$, their functional loss induced by potent vanilloids could not be easily distinguished [171]. Story et al. proposed that TRPA1 might be another cation channel co-expressed with TRPV1 [168], but no systematic study has been carried out to verify this notion and reveal the functional consequences of co-deletion. 


\section{Aims}

The primary aim of this research is to determine sensory modalities that may be lost after the RTX treatment of newborn or adult mice, and to dissect potential side-effect(s) of molecular neurosurgery, a promising new area of treatment of otherwise intractable pain conditions.

A second goal is to gather information relating to the structure and function of the channel by investigating the effects of divalent heavy metal cations on the TRPV1 and by collecting the literature data on the functionally important point mutations of the channel for prospective in silico modeling.

To accomplish the main goals, the following specific aims were identified:

- Determination of the potential effect of AITC on TRPV1.

- Testing of the sensitivity of the mice treated with RTX to vanilloids, in order to verify the effectiveness of RTX treatment in deleting TRPV1+ neurons.

- Assessment of the sensitivity of the mice treated with RTX to AITC, in order to investigate the extent of the coexpression of TRPV1 and TRPA1 in sensory neurons.

- Testing of the sensitivity of the RTX-treated mice with to heat, in order to assess the actual role of TRPV1 and coexpressed homologues in heat sensing.

- Immunohistology and Western blotting experiments in order to characterize the distribution of TRPV1, TRPA1 and TRPM8 in the DRG and TG neurons of RTX treated or untreated mice.

- Assessment of the interactions of divalent heavy metal cations with TRPV1 using vanilloid induced ${ }^{45} \mathrm{Ca}^{2+}$ uptake assays.

- Revalidation of the TRPV1 dependent $\mathrm{Co}^{2+}$ accumulation phenomenon by using $\left(\mathrm{NH}_{4}\right)_{n} \mathrm{~S}_{\mathrm{x}}$ histochemistry.

- Validation of the $\mathrm{Co}^{2+}$ inhibition phenomenon in in vivo tests.

- Collection of the mutational data of TRPV1 available in the literature and their organization in a form that facilitates in silico model building of the TRPV1. 


\section{Materials and methods}

Reagents stock solutions - $(200 \mathrm{mM})$ of $\mathrm{CoCl}_{2}, \mathrm{NiCl}_{2}, \mathrm{ZnSO}_{4}, \mathrm{CdCl}_{2}, \mathrm{CuSO}_{4}, \mathrm{CaCl}_{2}$, $\mathrm{CoCl}_{2}$ and $\mathrm{LaCl}_{3}$ were dissolved in water and diluted as required to the working concentrations. To avoid the precipitation of insoluble $\mathrm{La}(\mathrm{OH})_{3}$ and $\mathrm{La}\left(\mathrm{CO}_{3}\right)_{3}$, the formation of radiocolloids and the loss of $\mathrm{La}^{3+}$ by adsorption to container surfaces, $\mathrm{LaCl}_{3}$ solution was prepared fresh daily in polyethylene vials [172]. RuRed and CapZ (Sigma-Aldrich, St. Louis, MO) were dissolved in dimethyl sulfoxide (DMSO). CAPS was dissolved initially as a $3 \mathrm{mM}$ stock solution in $95 \%$ ethanol. The peptide $\mathrm{R}_{4} \mathrm{~W}_{2}$ was synthesized in our laboratories, then dissolved in water and used as a $25 \mathrm{mM}$ stock solution. Amitriptyline (AMI), purchased from Sigma-Aldrich, was dissolved in water. RTX (LC Laboratories, Woburn, MA) and CAPS (Sigma, St. Louis, MO) were dissolved in ethanol and further diluted in physiological saline solution. Allyl isothiocyanate (AITC) (Sigma, St. Louis, MO) was diluted in physiological salt solution and dispergated by ultrasonication before testing.

Plasmids - The C-terminally epsilon-tagged rat TRPV1e plasmid construct was prepared in the metallothionein (pMTH) plasmid vector as described earlier [31]. To avoid cell loss through the $\mathrm{Ca}^{2+}$-excytotoxic mechanism that occurs when TRPV1 is overexpressed at $37{ }^{\circ} \mathrm{C}$, only the basal activity of the pMTH promoter was used. The PKCE epitope tag allowed immunological detection of the TRPV1 $\varepsilon$ protein, as described earlier [173].

Cell lines expressing TRPV1 ectopically - The HaCaT keratinocyte cell line was a kind gift of Prof. B. Farkas (Department of Dermatology, University of Cologne, Federal Republic of Germany) [105]. The COS-7 (CRL-1651) and BALB/c-3T3 (CCL-163) cell lines were obtained from ATCC. The 3T3 and HaCaT cell lines permanently expressing the rTRPV1 channel were prepared as described earlier [174]. COS7 cells were transiently transfected with plasmid containing the wild-type TRPV1 channel by using the Fugene transfection reagent (Roche, Mannheim, Germany). The transfection efficacy was determined by flow cytofluorometry. 
Primary DRG cultures - DRG cultures were prepared from E16 embryonic rats as reported earlier [31]. DRGs were dissected and then processed in Hank's balanced salt buffer until plated in Dulbecco's Modified Eagle Medium (DMEM). The DMEM contained $20 \mathrm{mM}$ HEPES, pH 7.4, 7.5\% fetal bovine serum, 7.5\% horse serum, $5 \mathrm{mg} / \mathrm{ml}$ uridine supplemented with $2 \mathrm{mg} / \mathrm{ml} \mathrm{5-fluoro-2'-deoxyuridine} \mathrm{and} 40 \mathrm{ng} / \mathrm{ml}$ nerve growth factor (NGF) to inhibit cell division and to promote the differentiation of long neuronal processes, respectively. Cells were seeded on $25 \mathrm{~mm}$ glass coverslips.

${ }^{45} \mathbf{C a}^{2+}$ uptake assay - One day before the assay, HaCaT adherent cell lines ectopically expressing the C-terminally $\varepsilon$-tagged rTRPV1 and Cos7 cells transiently transfected with rTRPV1 were seeded in poly-D-lysine-coated 96-well flat-bottom plates (Orange Scientific, Braine-l'Alleud, Belgium) at a density of 20,000 cells/well. The plates were washed three times with assay medium $\left(\mathrm{Ca}^{2+}\right.$ - and $\mathrm{Mg}^{2+}$-free Hanks' balanced salt solution supplemented with $0.8 \mathrm{mM} \mathrm{MgCl}_{2}$ and with $25 \mathrm{mM}$ Tris- $\left.\mathrm{HCl}, \mathrm{pH}=7.4\right)$ at room temperature $\left(20-25^{\circ} \mathrm{C}\right)$. CAPS was diluted from a $3 \mathrm{mM}$ ethanol stock solution to the indicated final concentrations. Serial dilutions of reagents containing ${ }^{45} \mathrm{Ca}^{2+}$ were prepared, and the ${ }^{45} \mathrm{Ca}^{2+}$ uptake assay was performed for ten minutes at $24{ }^{\circ} \mathrm{C}$ using $1.33 \mu \mathrm{Ci} / \mathrm{ml}$ of ${ }^{45} \mathrm{Ca}^{2+}$ (Amersham Biosciences, Buckinghamshire, UK) in a final volume of $100 \mu \mathrm{l} /$ well. To stop ${ }^{45} \mathrm{Ca}^{2+}$ uptake and remove the free isotope, cells were washed three additional times and then lysed in $80 \mu$ lysis buffer/well (50 mM Tris-HCl, pH 7.5, $150 \mathrm{mM} \mathrm{NaCl,} \mathrm{1 \%} \mathrm{Triton} \mathrm{X-100,} \mathrm{0.1 \%} \mathrm{SDS,} 5 \mathrm{mM}$ EDTA) for 30 minutes. $70 \mu \mathrm{l}$ aliquots of the solubilised cell extracts were mixed with $100 \mu 1$ aliquots of Optiphase Supermix scintillation cocktail (Perkin Elmer, Wellesley, MA) and counted in a Perkin Elmer liquid scintillation counter.

To measure the effect of temperature on the TRPV1 function in the ${ }^{45} \mathrm{Ca}^{2+}$-uptake assay, TRPV1/HaCaT cells were plated on six-well plates. ${ }^{45} \mathrm{Ca}^{2+}$ uptake was evoked with $10 \mathrm{ml}$ preheated buffer. The procedure was followed as described above.

After the measurement, the data were corrected for the basal activity of TRPV1 and normalized from zero to one, where zero denotes the counts per minute in TRPV1/HaCaT cells without CAPS and one denotes the counts per minute in TRPV1/HaCaT cells with CAPS. The results of three parallel measurements were averaged and evaluated with PRISM $^{\text {TM }} 3.01$ software (GraphPad Software, Inc. San Diego, CA, USA). During curve 
fitting, the "Analyze/Nonlinear regression (curve fit)/Sigmoidal dose-response" menu of PRISM $^{\mathrm{TM}}$ software was applied.

The curve-fitting equation was: $\mathrm{Y}=\mathrm{Y}_{\min }+\left(\mathrm{Y}_{\max }-\mathrm{Y}_{\min }\right) /\left(1+10^{(\operatorname{logEC} 50-\mathrm{X})}\right)$, where $\mathrm{X}=$ logarithm of concentration and $\mathrm{Y}=$ the response.

RTX treatment - The studies were carried out on male CD/1 mice. $1 \mathrm{mg}$ RTX was dissolved in $500 \mu \mathrm{l} 96 \%$ ethanol, diluted in physiological saline and injected s.c. into the scruff of the neck in a volume of about $100 \mu \mathrm{l}$. The RTX was applied at a dosage of $50 \mu \mathrm{g} / \mathrm{kg}$ body weight under light ether anesthesia to avoid unnecessary pain. Control mice received vehicle. In the case of adult treatment, two to three months old adult mice weighing about $30 \mathrm{~g}$ at the start of the experiments were tested 10 days after RTX treatment. Mice treated on the second day of life were tested at two months of age. In the case of chronic RTX treatment, RTX was added at $20 \mu \mathrm{g} / \mathrm{kg}$ body weight daily for three days.

Eye wipe test - Eye wipe tests were performed on CD1 mice. $100 \mu \mathrm{M}$ CAPS solution, or a solution containing $100 \mu \mathrm{M}$ CAPS and $1 \mathrm{mM} \mathrm{CoCl}_{2}$, or a solution containing $100 \mu \mathrm{M}$ CAPS and $5 \mu \mathrm{M}$ CapZ, was dropped into the eye and the number of defensive wiping movements was then counted.

Cold tail-flick test - Animals were held over ice-cold water $\left(\sim 5^{\circ} \mathrm{C}\right)$ and their tails were approximately half-submerged into the bath. The time from immersion to tail removal or flicking was measured.

Cold plate test - A micro-plate thermostat set at $5{ }^{\circ} \mathrm{C}$ was used to generate a cold surface. Tested mice were placed on the plate, and the time to the first response of forelimb withdrawal and shivering was recorded.

Hot plate test - The animals were individually exposed to a hot plate maintained at $53{ }^{\circ} \mathrm{C}$. The time up to forepaw licking was taken as the response time. 
Water consumption - The daily water consumption of individually housed mice was measured. Each bottle contained tap water with AITC at a concentration of $0.1 \mathrm{mM}$.

Protein extraction and Western blotting - Tissue samples were homogenized in modified RIPA buffer (50 mM Tris-HCl, $140 \mathrm{mM} \mathrm{NaCl,} 5 \mathrm{mM}$ EDTA, 1\% TritonX-100, Protease Inhibitor Cocktail - Roche, Mannheim, Germany) and incubated on ice for 15 minutes to allow lysis to proceed. All samples were pre-cleared by centrifugation (15 minutes $12000 \mathrm{~g}$ at $4{ }^{\circ} \mathrm{C}$ ) before protein concentration determination by the bicinchonic acid (BCA) method (Sigma, St. Louis, MO). PAGE was performed as described in the Protein Electrophoresis technical manual of Amersham Biosciences (Buckinghamshire, UK). Protein samples were separated on $8 \%$ polyacrylamide gels, then transferred to Millipore Immobilon PVDF membrane using Tris-Glycine transfer buffer (0.192 M glycine, $25 \mathrm{mM}$ Tris, 20\% $\mathrm{MetOH})$. Transfer was followed by blocking of the membrane (30 minutes at room temperature (RT) in 5\% dry milk TBS-Tween), and incubation with primary antibody (overnight at $4{ }^{\circ} \mathrm{C}$, in $0.5 \%$ BSA TBS-Tween), secondary antibody ( 2 hours at RT, in $1 \%$ dry milk TBS-Tween). Results were revealed by using the ECL method (SuperSignal West Chemiluminescent Substrate (Pierce Biotechnology Inc. Rockford, IL), Hyperfilm ECL Amersham Biosciences, Buckinghamshire, UK). TBS: $50 \mathrm{mM}$ Tris, $140 \mathrm{mM} \mathrm{NaCl}, \mathrm{pH}$ 7.6; TBS-T: TBS with 0.5\%Tween-20. Antibodies used and their dilutions: TRPV1 - 1:1000, (ABR Bioreagents, PA1-747); TRPA1 - 1:1000, (Transgenic Inc. Kumamoto, Japan. \#KM120); TRPM8 - 1:1000, (Alomone Labs, Jerusalem, Israel \#ACC-049); ß-actin - 1:1000 (Sigma, St. Louis, MO \#A5060); anti-mouse and anti-rabbit HRP - 1:10000 (Sigma, St. Louis, MO \#A0168 and \#A6154, respectively).

Cobalt histochemistry - Rat DRG cells attached to coverslips were washed in buffer A (in millimolars: $\mathrm{NaCl}, 57.5 ; \mathrm{KCl}, 5 ; \mathrm{MgCl}_{2}, 2$; HEPES, 10; glucose, 12; sucrose, 139; $\mathrm{pH} 7.4$ ) for 2 minutes, and then incubated at $37{ }^{\circ} \mathrm{C}$ for 10 minutes in $\mathrm{Co}^{2+}$-uptake solution (buffer $\mathrm{A}+$ $\left.5 \mathrm{mM} \mathrm{CoCl}_{2}\right)$ containing $20 \mu \mathrm{M}$ CAPS. High $(20 \mu \mathrm{M})$ capsaicin concentration was used in order to obtain a robust and easily detectable $\mathrm{Co}^{2+}$ signal. Following a wash in buffer $\mathrm{A}$, the water-soluble $\mathrm{Co}^{2+}$ taken up by the cells was precipitated with $0.12 \%$ ammonium polysulfide (Sigma-Aldrich) in buffer A, which resulted in the formation of dark, water-insoluble CoS in 
TRPV1+ cells. Cells were fixed in $4 \%$ formaldehyde and mounted on glass slides, using Kaiser's glycerol gelatin (Merck, Darmstadt, FRG). Cells were examined under a Nikon light microscope (Melville, NY, USA) and photographed with a SPOT RT-SETM Digital Camera (Diagnostic Instruments). Pictures of the cells were analyzed by means of ImageJ 1.45s software (National Institutes of Health, USA), and the subsequent statistical analyses were performed with PRISMTM 3.01 software (GraphPad Software, Inc. San Diego, CA, USA).

Immunhistochemistry - Over-anesthetized mice were perfused intracardially with 4\% paraformaldehyde in $0.1 \mathrm{M}$ sodium phosphate buffer (PB, $\mathrm{pH}$ 7.4). TGs were dissected out, and cryoprotected in $10 \%$ glycerol / 30\% sucrose) overnight at $4{ }^{\circ} \mathrm{C}$. TGs were embedded in Tissue Tek OCT (Sakura Finetek, Torrance, CA) and frozen in dry ice. Frozen sections were cut on a Shandon Cryotome Fe (Thermo Fisher Middletown, VA) sliding microtome and collected in Superfrost slides kept at $-20{ }^{\circ} \mathrm{C}$. Sections were pre-incubated in blocking solutions (5\% goat serum, $0.1 \%$ Triton-X in PBS $\mathrm{pH}=7.4)$. The sections were next incubated in primary antibody dilutions at $4{ }^{\circ} \mathrm{C}$ for 24 hours, and then with secondary antibody. Antibodies used and their dilutions: TRPV1 1:50 (our monoclonal antibody directly labeled with Alexa Fluor 488); TRPA1 1:50 (rabbit polyclonal, Transgenic Inc. Kumamoto, Japan. \#KM120); TRPM8 1:50 (rabbit polyclonal, Alomone Labs, Jerusalem, Israel \#ACC-049); anti rabbit IgG-TRITC 1:400 (Sigma, St. Louis, MO). Sections were mounted on standard glass slides and coverslipped with Dako Faramount Aqueous Mounting Medium (Dako, Glostrup, Denmark).

Statistical analysis of the data - One-way ANOVA followed by Turkey's post tests was performed with GraphPad Prism version 3.01 software (GraphPad Software, Inc. San Diego, CA, USA) to compare the data groups of the different measurements.

All animal experimental protocols were approved by our institutional review committee and the responsible governmental agency. 


\section{Results}

\section{1. The effects of RTX-mediated molecular neurosurgery}

Although extremely specific for its target, TRPV1, RTX, can delete sensation modalities conferred by bystander sensor molecules, including other TRP channels co-expressed in the same neuron. A specific aim of this study, therefore was the determination of the potential loss/gain of sensations that RTX-mediated molecular surgery may cause. To determine the

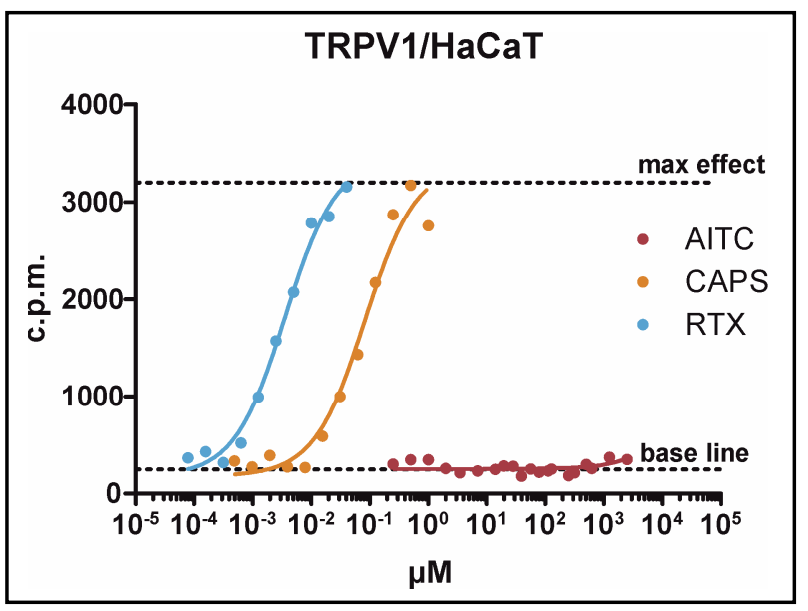

Figure 3: ${ }^{45} \mathrm{Ca}^{2+}$-influx of rTRPV1 HaCat cells

HaCaT keratinocytes expressing rTRPV1 were challenged in agonist-induced ${ }^{45} \mathrm{Ca}^{2+}$-influx assays for ten minutes. Cell-bound radioactivity was measured in a liquid scintillation counter. Only RTX and CAPS induced a $\mathrm{Ca}^{2+}$-influx, while AITC was totally ineffective. The experiment was repeated two additional times, with similar results. potential effect of AITC in vitro, we used a cell-based functional assay using a permanent cell line expressing TRPV1, but not TRPA1 ectopically. RTX and CAPS evoked a ${ }^{45} \mathrm{Ca}^{2+}$ influx with a half-maximal effective concentration $\left(\mathrm{EC}_{50}\right)$ of $2.6 \mathrm{nM}$ and $78 \mathrm{nM}$, respectively (3). In contrast to the report by Ohta et al. [83], however, we found that AITC has no effect on TRPV1expressing cells, since it did not evoke a $\mathrm{Ca}^{2+}$ influx at applied concentrations ranging from $125 \mathrm{nM}$ to $2.5 \mathrm{mM}$. The lack of an AITC effect on TRPV1 and the selectivity of this ligand for TRPA1 has recently been shown by others, too $[167,175]$. To dissect potential side-effect(s) of molecular neurosurgery in vivo, mice were treated with RTX either at birth or at adult age, the resulting changes in behavioral, cellular and molecular biomarkers (i.e. chemo, and heat sensitivity, tissue specific expression/distribution of TRPV1 and TRPA1) were systematically compared. As expected from previous studies [119], mice treated with RTX two days post-natal and tested at the age of two months had completely lost the sensitivity to vanilloids, since the CAPS-induced eye wipe, a behavioral marker of the TRPV1-conferred pain signal, was completely abrogated. We chose an RTX dose at which no mortality occurred. Under conditions applied in preliminary experiments, RTX-caused mortality was detected from $75 \mu \mathrm{g} / \mathrm{kg}$ body weight, while the maximal dose used in the subsequent experiments was $50 \mu \mathrm{g} / \mathrm{kg}$ body weight. 
We also noted that mice were unresponsive in AITC-induced eye wipe tests as well, as the AITC-induced eye wipes were completely abrogated. In accordance with that fact, these animals consumed AITC containing drinking water in a significantly higher volume overnight than untreated mice $(2.7 \pm 1.7 \mathrm{ml}$ vs. $5.5 \pm 1.5 \mathrm{ml})$, another signature of the specific loss of this sensory modality. Interestingly, they showed no change in temperature sensitivity in either the cold plate, or the hot plate assay (Figure 4).

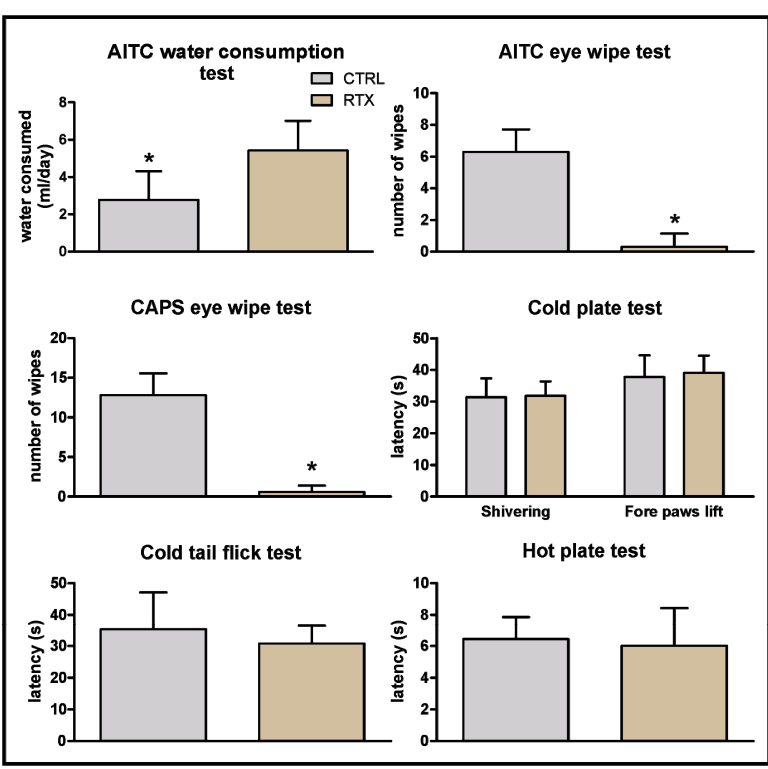

Figure 4: Changes in the chemical- and heat sensitivity of mice treated with RTX at $50 \mu \mathrm{g} / \mathrm{kg}$ body weight on the second day after birth.

Mice were tested at second month of their life. Comparisons were made using age-matched control animals treated with vehicle only. Bars represent means plus S.D. $(n=7)$. The experiments were repeated two additional times with similar results. $A$ Oral aversion to AITC. RTX-treated mice consumed significantly more AITC containing drinking water than untreated mice in a $24 \mathrm{~h}$ test. ${ }^{*} P<0.05$ vs. control B, C - Eye wipe response to corneal application of $100 \mu M$ CAPS and $10 \mathrm{mM} \mathrm{AITC.}$ Neonatal RTX administration significantly reduced the eye wipe response to corneal application of CAPS and also to AITC. ${ }^{*} P<0.05$ vs. control. D - Cold plate test. Paw withdrawal latency (left) or time to first shiver (right) were measured following placement of mice on a plate maintained at $5^{\circ} \mathrm{C}$. Responses were not significantly different. $E$ - Response latency in the tail immersion into $4^{\circ} \mathrm{C}$ cold water. No significant differences were seen between control and $R T X$ treated animals. F-Licking latencies in the hot plate assay at $53^{\circ} \mathrm{C}$. The responses were not significantly different.

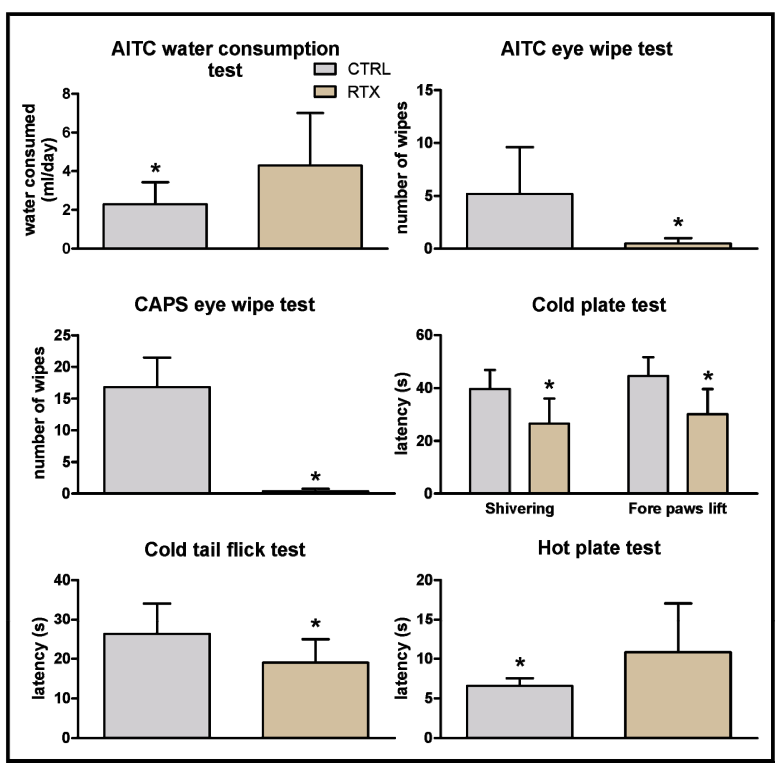

Figure 5: Changes in the chemical- and heat sensitivity of mice treated with $50 \mu \mathrm{g} / \mathrm{kg} \mathrm{RTX}$ at adult age.

Mice were tested two weeks later. Comparisons were made using age matched control animals treated with vehicle only. Bars represent means plus S.D. $(n=7)$. The experiments were repeated two additional times with similar results. A - Oral aversion to AITC. RTXtreated mice consumed significantly more AITC containing drinking water than untreated mice in $24 \mathrm{~h}$ tests. ${ }^{*} P<0.05$ vs. control $B, C-$ Eye wipe response to corneal application of $100 \mu M C A P S$ and $10 \mathrm{mM}$ AITC. RTX administration significantly reduced the eye wipe response to corneal application of CAPS and AITC. ${ }^{*} P<0.05$ vs. control. D - Cold plate test. Paw withdrawal latency (left) or time to first shiver (right) was measured following placement of mice on a plate maintained at $5^{\circ} \mathrm{C}$. Treated mice showed more sensitivity to cold. ${ }^{*} P<0.0001$ vs. control. E Response latency in the tail immersion into $4^{\circ} \mathrm{C}$ cold water. Significant differences were seen between control and RTX treated animals. ${ }^{*} P<0.05$ vs. control. F - Licking latencies in the hot plate assay at $53^{\circ} \mathrm{C}$ Responses were significantly different. RTX treated animals had longer reaction times. ${ }^{*} p<0.05$ vs. control. 
Mice treated with one dose of RTX at adult age become similarly unresponsive to chemical stimuli, i.e., they did not respond either to CAPS or AITC in the eye wipe tests, and they were also able to consume AITC-containing drinking water in high quantities. In addition, the animals that underwent RTX-mediated neurosurgery at adult age exhibited changes in heat sensitivity. As was expected from previous observations [119], the loss of TRPV1-expressing neurons resulted in decreased heat sensitivity. Surprisingly, however, the RTX-treated animals also became more sensitive to cold, showing a marked reduction in the response time (around 30\%) on cold plate as measured in cold plate tail flick and cold plate shivering tests (Figure 5). In the case of chronic RTX treatment $(3 \times 20 \mu \mathrm{g} / \mathrm{kg}$ body weight rather than $1 \times 50 \mu \mathrm{g} / \mathrm{kg}$ body weight) the mice similarly became unresponsive to CAPS. However, these mice lost their heat sensitivity to a higher extent relative to the mice which took part in acute treatment, so chronic treatment seemed to be more effective than a single treatment in this respect (Figure 6). Immunohistological staining experiments performed on adult mice treated with 1 x $50 \mu \mathrm{g} / \mathrm{kg}$ body weight RTX confirmed that TRPV1 is indeed lost after the treatment. The staining was performed with a new monoclonal antibody developed in our laboratory. Our hybridoma cell line was established from a normal BALB/c mouse immunized previously with a crude plasma membrane fraction isolated from a BALB/c 3T3 cell line permanently expressing the rat TRPV1. By employing indirect fluorescent labeling technologies, the monoclonal antibody was verified to react with an extracellular loop of both rat and mouse TRPV1. Parallel to TRPV1, TRPA1 also disappeared from the TGs of the RTX treated

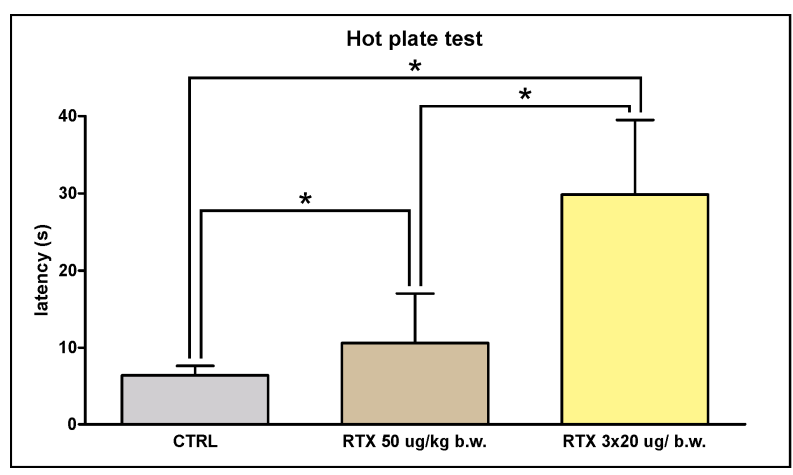

Figure 6: Comparison of acute and chronic RTX treatment

Chronic RTX (3 x $20 \mu \mathrm{g} / \mathrm{kg}$ body weight) is more effective than acute treatment (1 $x 50 \mu \mathrm{g} / \mathrm{kg}$ body weight) as measured in a hot plate assay. Bars represent means plus S.D. Statistics were made by LSD post hoc test following one-way ANOVA, *P< 0.05 vs. control.

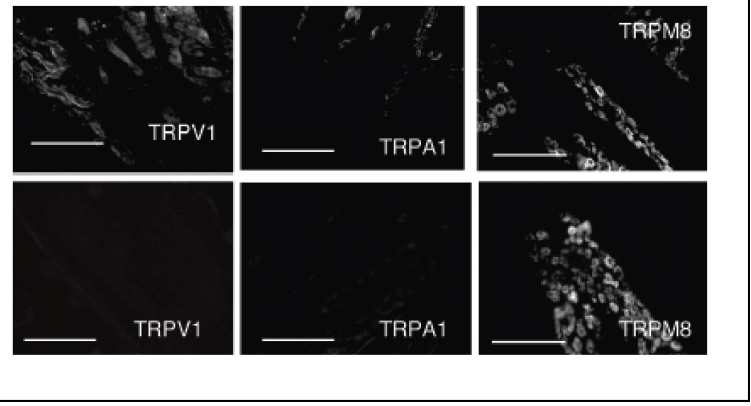

Figure 7: Microscopic images showing the effect of RTX on TRPV1+, TRPA1+ and TRPM8+ trigeminal ganglion neurons.

Unlike TRPM8, both TRPV1 and TRPA1 immunoreactivity was lost in the treated animals. Bar represents $0.2 \mathrm{~mm}$. 
animals (Figure 7), but the TRPM8-positive cells remained readily detectable. TRPA1 and TRPM8 were stained with commercially available antibodies. The correlation between TRPV1 and TRPA1 levels in the DRG and TG with the changes in chemical and heat

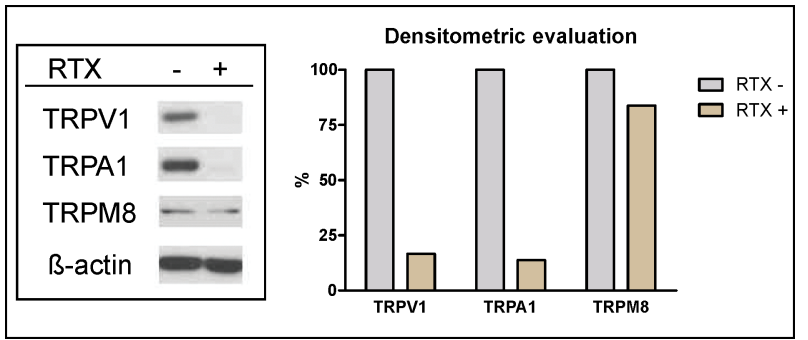

Figure 8: Western blot analysis of the trigeminal ganglions

Western blot shows the level of TRPV1, TRPA1 and TRPM8 proteins in the lysates of pooled trigeminal ganglions obtained from control and RTX treated mice. Similarly to TRPV1, TRPA1 also disappears from the trigeminal ganglions of treated animals, while TRPM8 does not change. Sigma beta-actin was used in the Western blot as an internal control. sensitivity in mice treated at adult age was tested in Western blot experiments. In this case, TRPV1, TRPA1 and TRPM8 were immunostained with commercially available polyclonal antibodies. Our Western blotting experiments confirmed that, in parallel with TRPV1, TRPA1 also disappeared from the TGs of the RTX-treated animals; the decrease was $83 \%$ in the case of TRPV1, and $86 \%$ in the case of TRPA1, while the amount of TRPM8 changed only barely, non-significantly (Figure 8).

\section{2. The effects of divalent heavy metal cations on the TRPV1 receptor}

Various studies have revealed that positively charged molecules can act as TRPV1 receptor channel blockers by plugging the pore. RuRed (a well-known but non-specific TRPV1 pore blocker) [176], $\mathrm{R}_{4} \mathrm{~W}_{2}$ (a positively charged hexapeptide) [67] and anti-calmodulins/antipsychotic tricyclics [177] have been demonstrated to be able to bind to the DXEXXEXXD domain of TRPV1, whereby they block the movement of $\mathrm{Ca}^{2+}$ through the pore region.

We assessed the effects of various metal cations on the vanilloid-induced activity of the TRPV1 channel. In the ${ }^{45} \mathrm{Ca}^{2+}$ uptake assay, the $\mathrm{EC}_{50}$ of CAPS for wild-type TRPV1 was determined to be $0.0860 \mu \mathrm{M}$. Approximately $1 \mu \mathrm{M}$ CAPS caused the full activation (maximum effective concentration - $\mathrm{EC}_{100}$ ) of TRPV1 at $\mathrm{pH}$ 7.5. Channel blocker-screening assays were therefore carried out with $2 \mu \mathrm{M}$ CAPS (an excess amount of agonist), which does not cause $\mathrm{Ca}^{2+}$ cytotoxicity during the 10-min incubation period. The interactions of the metal ions with TRPV1 were studied by using a vanilloid-induced ${ }^{45} \mathrm{Ca}^{2+}$-uptake assay. Experiments 
were carried out on the TRPV1/HaCaT permanent indicator cell line. Channel opening was induced by CAPS in the presence of progressively increasing divalent metal cation $\left(\mathrm{M}^{2+}\right)$

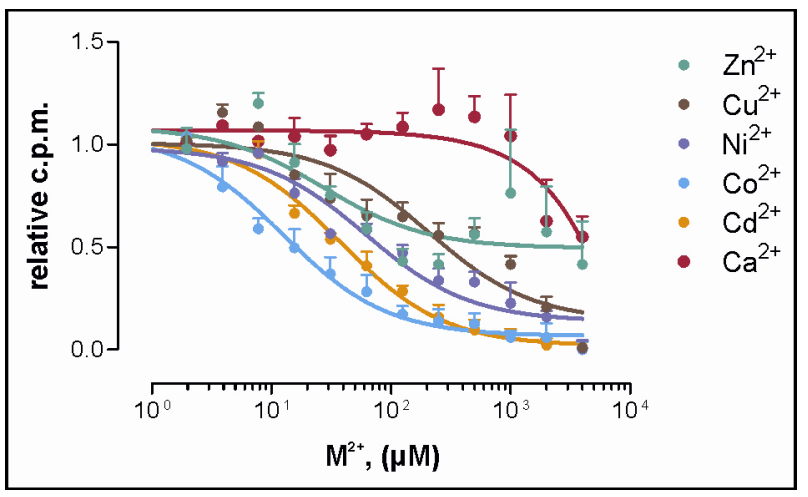

Figure 9: Ranking divalent cations as channel blockers

Efficacy of $\mathrm{M}^{2+}$ inhibitors of TRPVI ranked by vanilloid-induced ${ }^{45} \mathrm{Ca}^{2+}$ uptake. The sequence of potency is: $\mathrm{Co}^{2+}>\mathrm{Cd}^{2+}>\mathrm{Ni}^{2+}>\mathrm{Cu}^{2+}>>>\mathrm{Zn}^{2+}$ Data are mean values $\pm S$.D. of the results of three independent experiments.

concentrations in the uptake solution. Incubation of the cells in uptake solutions containing both ${ }^{45} \mathrm{Ca}^{2+}$ and $\mathrm{Mg}^{2+}, \mathrm{Mn}^{2+}$ or $\mathrm{La}^{3+}$ (data not shown) resulted in little or no effect, even at the highest concentration (4 $\mathrm{mM})$, whereas $\mathrm{Zn}^{2+}$ proved to be a weak $\left(\mathrm{IC}_{50}=27 \mu \mathrm{M}\right)$ and only partial inhibitor of the $2 \mu \mathrm{M}$ CAPS-induced ${ }^{45} \mathrm{Ca}^{2+}$ uptake. The other cations effectively blocked the vanilloid-induced $\mathrm{Ca}^{2+}$ entry into TRPV1/HaCaT cells, with the following sequence of potency: $\mathrm{Co}^{2+}\left(\mathrm{IC}_{50}=13 \mu \mathrm{M}\right)>$ $\mathrm{Cd}^{2+}\left(\mathrm{IC}_{50}=38 \mu \mathrm{M}\right)>\mathrm{Ni}^{2+}\left(\mathrm{IC}_{50}=62 \mu \mathrm{M}\right)>\mathrm{Cu}^{2+}\left(\mathrm{IC}_{50}=200 \mu \mathrm{M}\right)($ Figure 9). To assess the effect of $\mathrm{Co}^{2+}$, the most potent TRPV1 inhibitor, on the heat-activated TRPV1 channels, the activity of TRPV1 was investigated in the presence either of $2 \mu \mathrm{M}$ CAPS alone or of $2 \mu \mathrm{M}$ CAPS $+250 \mu \mathrm{M} \mathrm{Co}^{2+}$, at both $37{ }^{\circ} \mathrm{C}$ and $42{ }^{\circ} \mathrm{C}$. The negative control did not contain CAPS. In this assay, high temperature activated the TRPV1 channels and also increased the

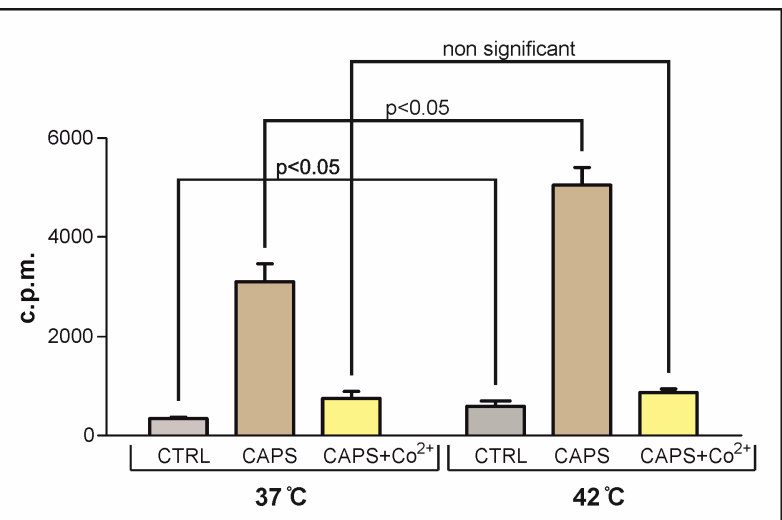

Figure 10: $\mathrm{Co}^{2+}$ effect on heat-induced TRPV1 activity

$\mathrm{Co}^{2+}$ inhibits heat-induced $\mathrm{Ca}^{2+}$ uptake at $37{ }^{\circ} \mathrm{C}$ and at $42{ }^{\circ} \mathrm{C}$ in vanilloid-induced ${ }^{45} \mathrm{Ca}^{2+}$ uptake assay. Bars represent means plus S.D. of the results of three independent experiments. Statistical significance was assessed by post hoc LSD t tests after significant one-way analysis of variance (ANOVA). $P<0.05$.

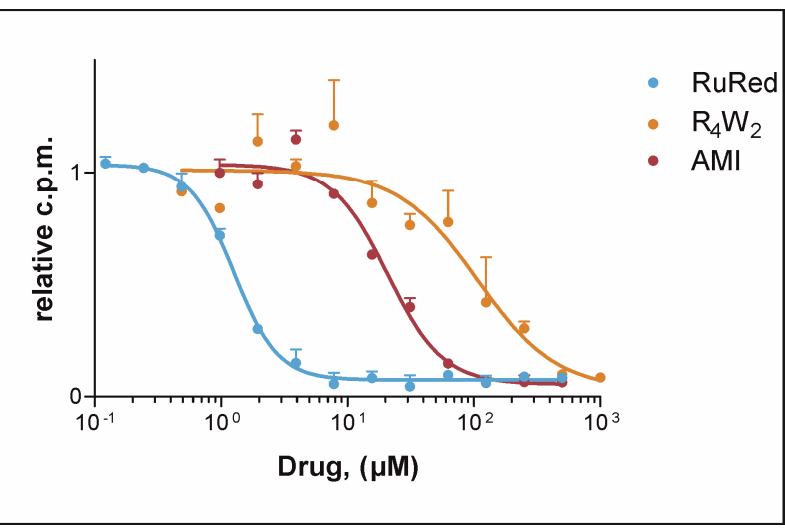

Figure 11: Effect of selective channel blockers on the TRPV1 activity

RuRed, $R_{4} W_{2}$ and AMI, selective channel blockers of TRPV1, were also tested for better comparison of inhibitors. Data are means plus S.D. of the results of three independent experiments. 
CAPS-evoked ${ }^{45} \mathrm{Ca}^{2+}$ influx. $\mathrm{Co}^{2+}$ reduced both the heat and CAPS-induced ${ }^{45} \mathrm{Ca}^{2+}$ influx (Figure 10).

To compare the potency of $\mathrm{Co}^{2+}$ with those of the other positively charged channel blockers, we measured the $\mathrm{IC}_{50}$ values of RuRed, $\mathrm{AMI}$ and $\mathrm{R}_{4} \mathrm{~W}_{2}$, which are known to have a docking site in the pore loop of TRPV1. The inhibitor potentials of these pore blockers were measured via the CAPS-induced ${ }^{45} \mathrm{Ca}^{2+}$ uptake. All of them inhibited CAPS-activated TRPV1, with the following $\mathrm{IC}_{50}$ values: $\mathrm{RuRed}=1 \mu \mathrm{M}, \mathrm{AMI}=20 \mu \mathrm{M}$ and $\mathrm{R}_{4} \mathrm{~W}_{2}=100 \mu \mathrm{M}$ (Figure 11).

For a better understanding of the inhibition kinetics of $\mathrm{Co}^{2+}$ on TRPV1, increasing concentrations of both $\mathrm{Co}^{2+}$ and CAPS were applied in the vanilloid-induced ${ }^{45} \mathrm{Ca}^{2+}$-uptake assays. The $\mathrm{Ca}^{2+}$ uptake of TRPV1/HaCaT cells was inhibited by the simultaneous presence of $\mathrm{Co}^{2+}$ in a dose-dependent manner. However, increasing concentrations of $\mathrm{Co}^{2+}$ decreased only the maximal response of efficacy $\left(\mathrm{E}_{\max }\right)$ of $\mathrm{Ca}^{2+}$ entry; the affinity of CAPS for TRPV1 did not change. The inflection point in the CAPS dose-response curves in each of the $\mathrm{Co}^{2+}$ co-incubation studies was found at $\sim 0.08 \mu \mathrm{M}$ (i.e. $\mathrm{EC}_{50}$ ), independently of the $\mathrm{Co}^{2+}$ concentration. The $\mathrm{Co}^{2+}$ inhibition patterns unequivocally indicated channel blocking kinetics (Figure 12A).

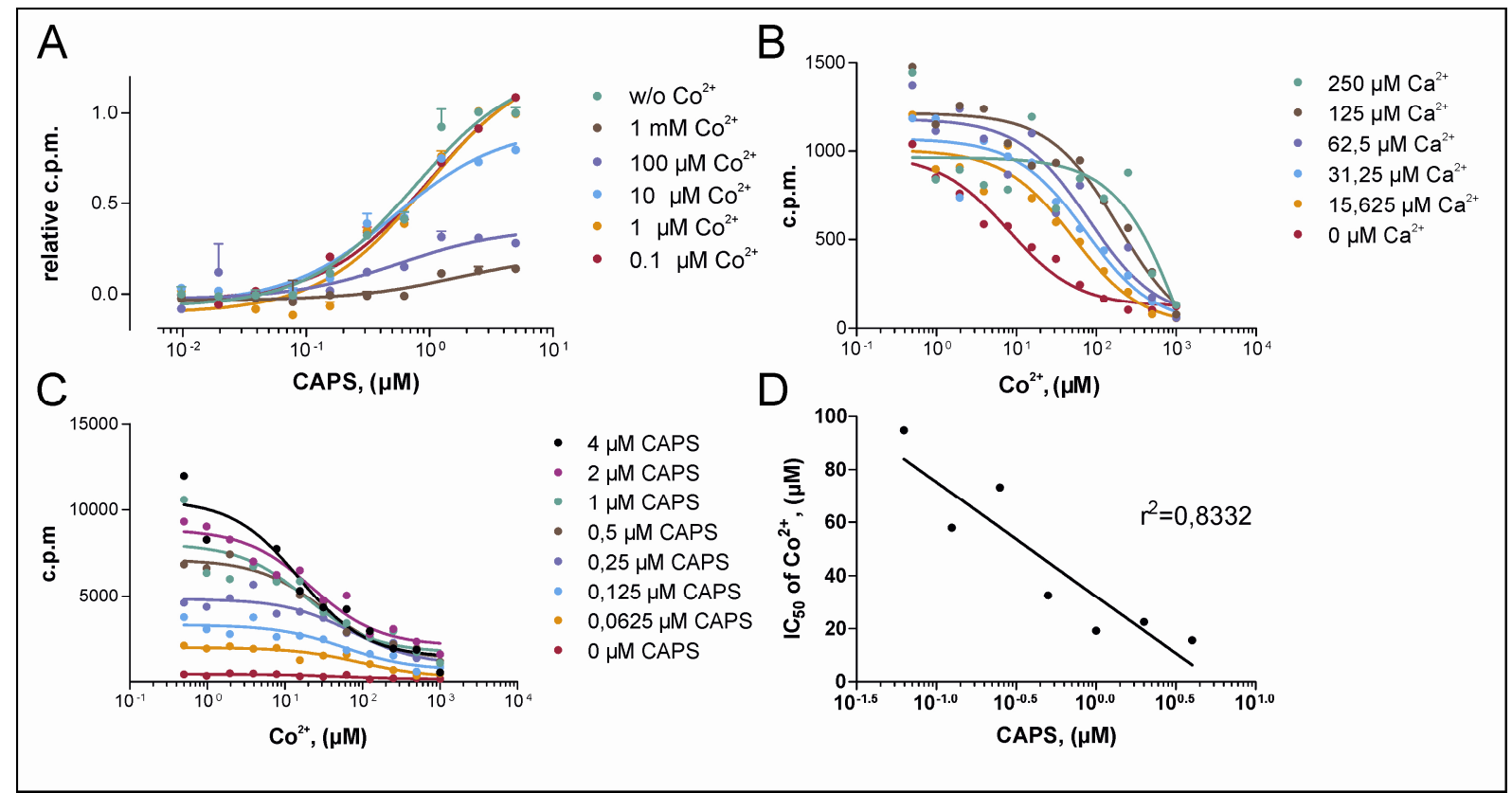

Figure 12: $\mathrm{Co}^{2+}$ inhibits $\mathrm{Ca}^{2+}$ entry through the TRPV1 channel

$A$ - Kinetics of inhibition of $\mathrm{Ca}^{2+}$ transport by $\mathrm{Co}^{2+}$ in TRPVI+ cells. Data are mean values plus S.D. of the results of three independent experiments. $B$ - Kinetics of competition between $\mathrm{Co}^{2+}$ and cold $\mathrm{Ca}^{2+}$ in $T R P V 1+$ cells. $C-C^{2+}$ blockage at different CAPS concentrations. Representative data are shown from independent experiments repeated at least three times. $D-I C_{50}$ values as a function of CAPS concentrations. $I C_{50}$ values of $\mathrm{Co}^{2+}$ in the presence of $0.0625,0.125,0.25,0.5,1,2$ or $4 \mu M$ CAPS are 94.81, 57.97, 73.17, $32.6,19.22,22.55$ and $15.62 \mu M$, respectively. 
By varying the concentrations of $\mathrm{Co}^{2+}$ and $\mathrm{Ca}^{2+}$ and measuring the radioactive ${ }^{45} \mathrm{Ca}^{2+}$ influx, we assessed whether there was a competition between $\mathrm{Co}^{2+}$ and $\mathrm{Ca}^{2+}$. The effect of dilution on the amount of accumulated ${ }^{45} \mathrm{Ca}^{2+}$ did not appear at extracellular cold $\mathrm{Ca}^{2+}$ concentrations below $1 \mathrm{mM}$ (Figure 9), indicating that TRPV1+ cells accumulate $\mathrm{Ca}^{2+}$ very effectively from the extracellular space and collect them putatively into ER or mitochondria. Increasing cold $\mathrm{Ca}^{2+}$ concentration decreased the inhibitory effect of $\mathrm{Co}^{2+}\left(\mathrm{IC}_{50}\right.$ values in the presence of $0 \mu \mathrm{M}, 15.625 \mu \mathrm{M}, 31.25 \mu \mathrm{M}, 62.5 \mu \mathrm{M}$ and $125 \mu \mathrm{M}$ cold $\mathrm{Ca}^{2+}$ : $7.944 \mu \mathrm{M}$, $51.22 \mu \mathrm{M}, 72.69 \mu \mathrm{M}, 79.09 \mu \mathrm{M}$ and $189.1 \mu \mathrm{M}$, respectively), showing that the effect of $\mathrm{Co}^{2+}$ on $\mathrm{Ca}^{2+}$ entry mainly depends on the competition for entry sites. These results suggest that the $\mathrm{Co}^{2+}$ entry through the TRPV1 channel is slower, and the $\mathrm{Co}^{2+}$ displacing the $\mathrm{Ca}^{2+}$ from the pore region of TRPV1 slows down or inhibits the $\mathrm{Ca}^{2+}$ uptake (Figure 12B).

The prolonged agonist stimulation of TRPV1 has been reported to result in an increased permeability to larger cations [178] or small molecules [179], due to conformational changes in the open state of the TRPV1. Thus, we analyzed the kinetics of the channel-blocking activity of $\mathrm{Co}^{2+}$ by employing different CAPS concentrations. An anticipated shift in the $\mathrm{IC}_{50}$ of $\mathrm{Co}^{2+}$ would be evidence supporting the idea that $\mathrm{Co}^{2+}$ entry depends on the TRPV1 open stages. We indeed observed a shift in the $\mathrm{IC}_{50}$ of $\mathrm{Co}^{2+}$, which decreased with increasing CAPS concentration (Figure 12C). Consequently, increasing agonist concentration enhances the blocking ability of $\mathrm{Co}^{2+}$. To investigate this phenomenon, we plotted the $\mathrm{IC}_{50}$ values as a function of CAPS concentration. Curve-fitting analysis confirmed a strong interrelationship between $\mathrm{IC}_{50}$ and the CAPS dose applied (Figure 12D), suggesting that the increased efficiency of inhibition correlates with the different open-state conformations of the TRPV1 channel.

We traced $\mathrm{Co}^{2+}$ upon vanilloid induction in sensory neuron cultures prepared from DRGs of rat embryos. To test $\mathrm{Co}^{2+}$-accumulation patterns, cells were co-incubated with $20 \mu \mathrm{M}$ CAPS in $\mathrm{Co}^{2+}$-containing $\mathrm{Ca}^{2+}$-uptake medium and the $\mathrm{Co}^{2+}$ was then localized by means of $\left(\mathrm{NH}_{4}\right)_{n} \mathrm{~S}_{\mathrm{x}}$ histochemistry. These experiments revealed that $\mathrm{Co}^{2+}$ not only competes with $\mathrm{Ca}^{2+}$, but also enters into the cytosol of specific PNS sensory neurons. Functionally responsive vanilloid-sensitive neurons (i.e. TRPV1+) exhibited dark-brown $\mathrm{Co}^{2+}$ precipitates inside the rounded neuronal bodies (Appendix Figure 1E). As expected from previous studies, TRPV1 is endogenously expressed in approximately one-third of the cultured neurons [180-183]. 
Without CAPS, no intracellular $\mathrm{Co}^{2+}$ accumulation was observed (data not shown). Similar experiments were carried out on rTRPV1/HaCaT and rTRPV1/3T3 cell lines. The accumulation of $\mathrm{Co}^{2+}$ was blocked by RuRed, a channel blocker of heat and vanilloid pain signalling. Moreover, the dose-dependent inhibition of the cellular entry of $\mathrm{Co}^{2+}$ was

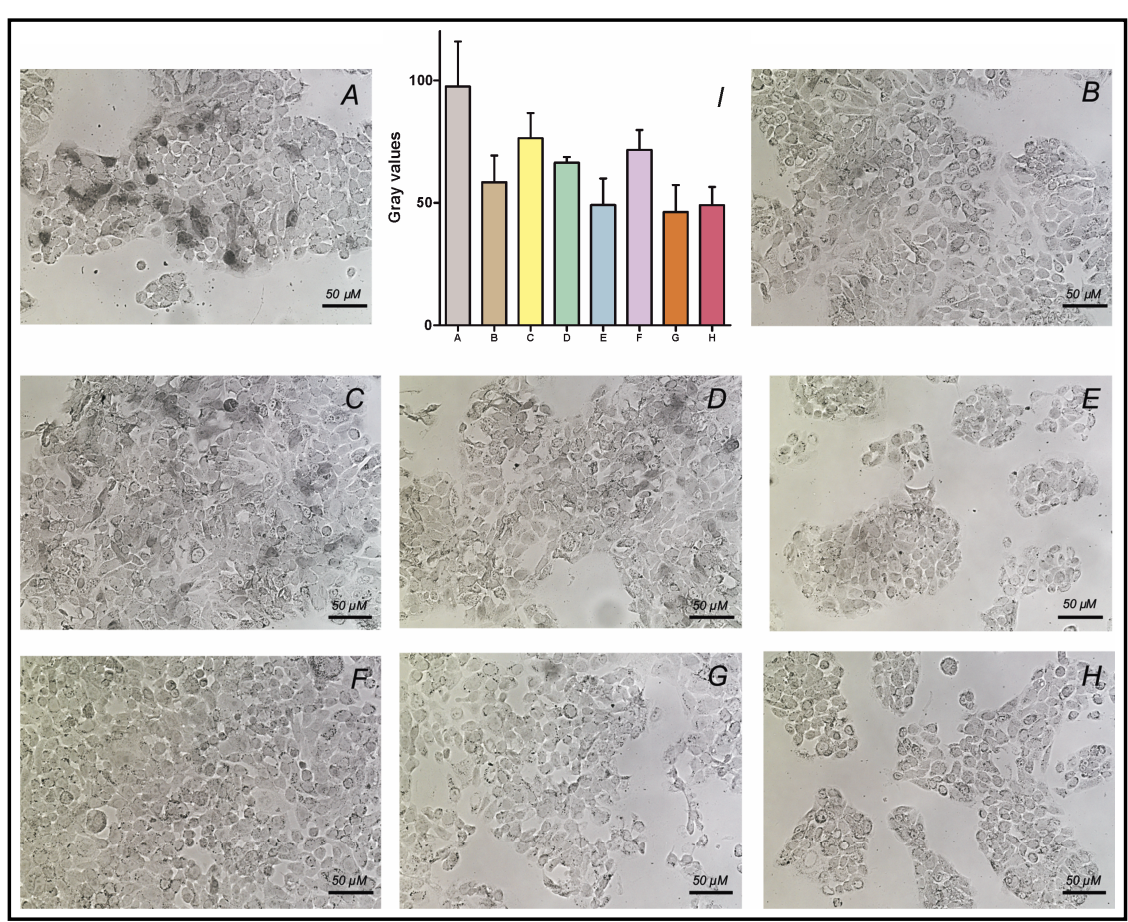

Figure 13: $\mathrm{Co}^{2+}$ histochemistry on the HaCaT cell line expressing TRPV1 ectopically.

Cells were incubated for 10 minutes in buffer A containing: A - $20 \mu M$ CAPS $+5 \mathrm{mMCO} \mathrm{Co}^{2+} ; \mathrm{B}-5 \mathrm{mMCO} \mathrm{Co}^{2+}$ without CAPS; $C-20 \mu \mathrm{MCAPS}+5 \mathrm{mMCo} \mathrm{Co}^{2+}$ +300 nM CapZ; D - $20 \mu M$ CAPS + 5mM Co ${ }^{2+}+5 \mu M$ CapZ; E $-20 \mu M$ $C A P S+5 \mathrm{mMCO}^{2+}+100 \mu \mathrm{MCapZ} ; \mathrm{F} 20 \mu \mathrm{MCAPS}+5 \mathrm{mMCO}^{2+}+500 \mathrm{nM}$ RuRed; G - $20 \mu M C A P S+5 m M \mathrm{Co}^{2+}+7 \mu M$ RuRed; $H-20 \mu M C A P S+5$ $m M \mathrm{Co}^{2+}+100 \mu \mathrm{M}$ RuRed. The dark precipitates indicate the presence of intracellular CoS that is blockable with RuRed, a channel blocker of heat and vanilloid pain signalling. Co-application of CapZ, a competitive antagonist of pungent vanilloids, also inhibited the cellular entry of $\mathrm{Co} 2+$ in a dose-dependent manner: this is a well characterized evidence-based method of localization of intracellular $\mathrm{Co}^{2+}$. I - Gray values of the HaCaT cell line expressing TRPV1 measured by means of ImageJ software. determined by the coapplication of $5 \mu \mathrm{M}$ CapZ, a long-known competitive antagonist of pungent vanilloids. After analysis of the photographs of the cells with the Image J program, statistical analysis of the data further confirmed our findings: the mean gray values of CAPS-exposed, CAPS-free, and CapZexposed cells proved to be significantly different (CAPS without $\mathrm{Co}^{2+}$ : $72.05 \pm 12.38$ (S.D.), $\mathrm{n}=146 ;$ CAPS $+\mathrm{Co}^{2+}$ : $124.4 \pm 21.51$ (S.D.), $\mathrm{n}=111 ; \mathrm{CAPS}+\mathrm{Co}^{2+}+$ CapZ: $76.92 \pm 22.21$ (S.D.), $\mathrm{n}=100 ; \mathrm{P}$ values of the $\mathrm{t}$ tests: CAPS without $\mathrm{Co}^{2+}$ vs. CAPS $+\mathrm{Co}^{2+}: \mathrm{P}<0.0001 ; \mathrm{CAPS}+\mathrm{Co}^{2+}$ vs. CAPS + $\mathrm{Co}^{2+}+\mathrm{CapZ}: \mathrm{P}<0.0001$; CAPS without $\mathrm{Co}^{2+}$ vs. CAPS $+\mathrm{Co}^{2+}+\mathrm{CapZ}: \mathrm{P}=0.0290$ ) (Appendix Figure 1). The gray values were measured on the negatives of the images: the darker the cells, the higher the gray values. Analysis of the pictures in Figure 13, showing TRPV1-expressing HaCaT cells, resulted in the same outcome. Following ANOVA, the groups were compared 
by using $\mathrm{t}$ tests. Each $\mathrm{t}$ test except that involving CAPS without $\mathrm{Co}^{2+}$ vs. CAPS $+\mathrm{Co}^{2+}+$ $100 \mu \mathrm{M}$ CapZ indicated a significant difference between the pairs of groups $(\mathrm{P}<0.05)$ (Figure 13).

No substantial staining could be observed on 3T3 cells (Appendix Figure 2A-E). Statistical analysis of the gray values of the cells indicated no significant darkening in the absence of TRPV1 in the cell membrane.

In order to rule out the possibility that $\mathrm{Co}^{2+}$ can enter the cells through voltage-gated calcium channels (VGCCs), 3T3 cells were challenged with $50 \mathrm{mM}$ extracellular $\mathrm{KCl}$. These cells did not show any VGCC activity: the high extracellular $\mathrm{KCl}$ concentrationinduced depolarization that opens the VGCC channels did not cause ${ }^{45} \mathrm{Ca}^{2+}$ accumulation in the ${ }^{45} \mathrm{Ca}^{2+}$-uptake assay.

Moreover, the VGCC blocker Nisoldipine did not decrease the CAPS induced TRPV1mediated ${ }^{45} \mathrm{Ca}^{2+}$ accumulation (data not shown). No $\mathrm{Co}^{2+}$ staining was observed in the presence of $50 \mathrm{mM}$ extracellular $\mathrm{KCl}$ (Appendix Figure 2F-J). ANOVA indicated no significant differences among the groups $(\mathrm{P}=0.9150)$. These results confirm that the CAPS-induced $\mathrm{Ca}^{2+}$ and $\mathrm{Co}^{2+}$ influx in TRPV1/3T3 cells is due exclusively to the TRPV1 channel activity.

Besides the in vitro demonstration of $\mathrm{Co}^{2+}$ antagonism, we further validated this $\mathrm{Co}^{2+}$

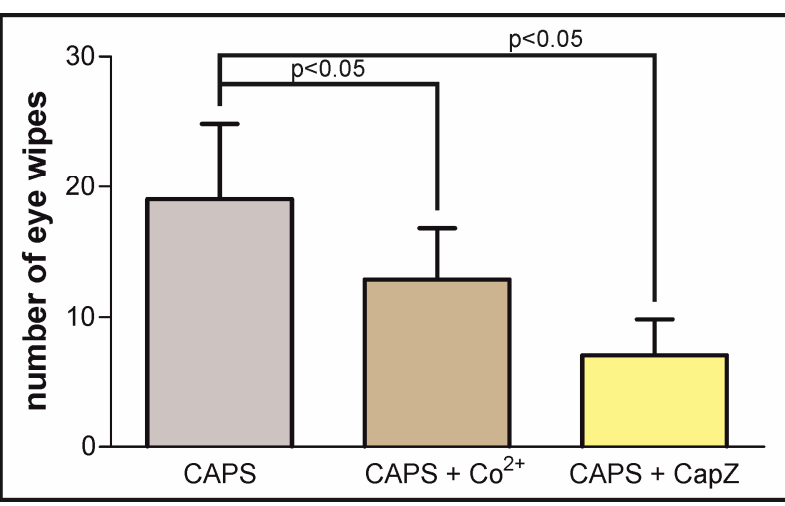

Figure 14: Eye wipe responses to the corneal application of CAPS alone or together with $\mathrm{Co}^{2+}$ or CapZ.

$\mathrm{Co}^{2+}$ decreased the frequency of vanilloid-evoked defending movements. Inhibition experiments with CapZ cross-validated and confirmed our earlier findings Statistical significance of inhibition was assessed by means of the paired t test $(P<0.05)$. Data are means plus S.D. of the results of eight independent experiments (n08). inhibition phenomenon in tests of eye wiping in response to pungent vanilloids $[184] . \mathrm{Co}^{2+}$ again decreased the frequency of vanilloid-evoked defending movements. Inhibition experiments with CapZ crossvalidated and confirmed our earlier findings (Figure 14).

To follow the line with the resolution of the structure and function of the TRPV1 channel, the next specific goal of this research was to create an overview of the currently available results of site-directed mutagenesis studies on transient receptor 
potential vanilloid type 1 (TRPV1) receptor. Systematization of the vast number of data on the functionally important amino acid mutations of TRPV1 may provide a clearer picture of this field, and may promote a deeper understanding of the relationship between the structure and function of TRPV1. We summarized information on 112 unique mutated sites along the TRPV1, exchanged to multiple different residues in many cases. These mutations influence the effect or binding of different agonists, antagonists, and channel blockers, alter the responsiveness to heat, acid, and voltage dependence, affect the channel pore characteristics, and influence the regulation of the receptor function by phosphorylation, glycosylation, calmodulin, PIP2, ATP, and lipid binding.

The above mentioned data is published in a form that facilitates in silico molecular modeling of the receptor by promoting easier establishment of boundary conditions [185], but its detailed discussion would exceed the limits of this thesis. Appendix Table 1 summarizes the information of the mutants, enabling an effective usability and easier comprehensibility of the data. Figure 15 indicates the mutated residues and the functional changes evoked by them, and also depicts the most important structural properties of TRPV1. 


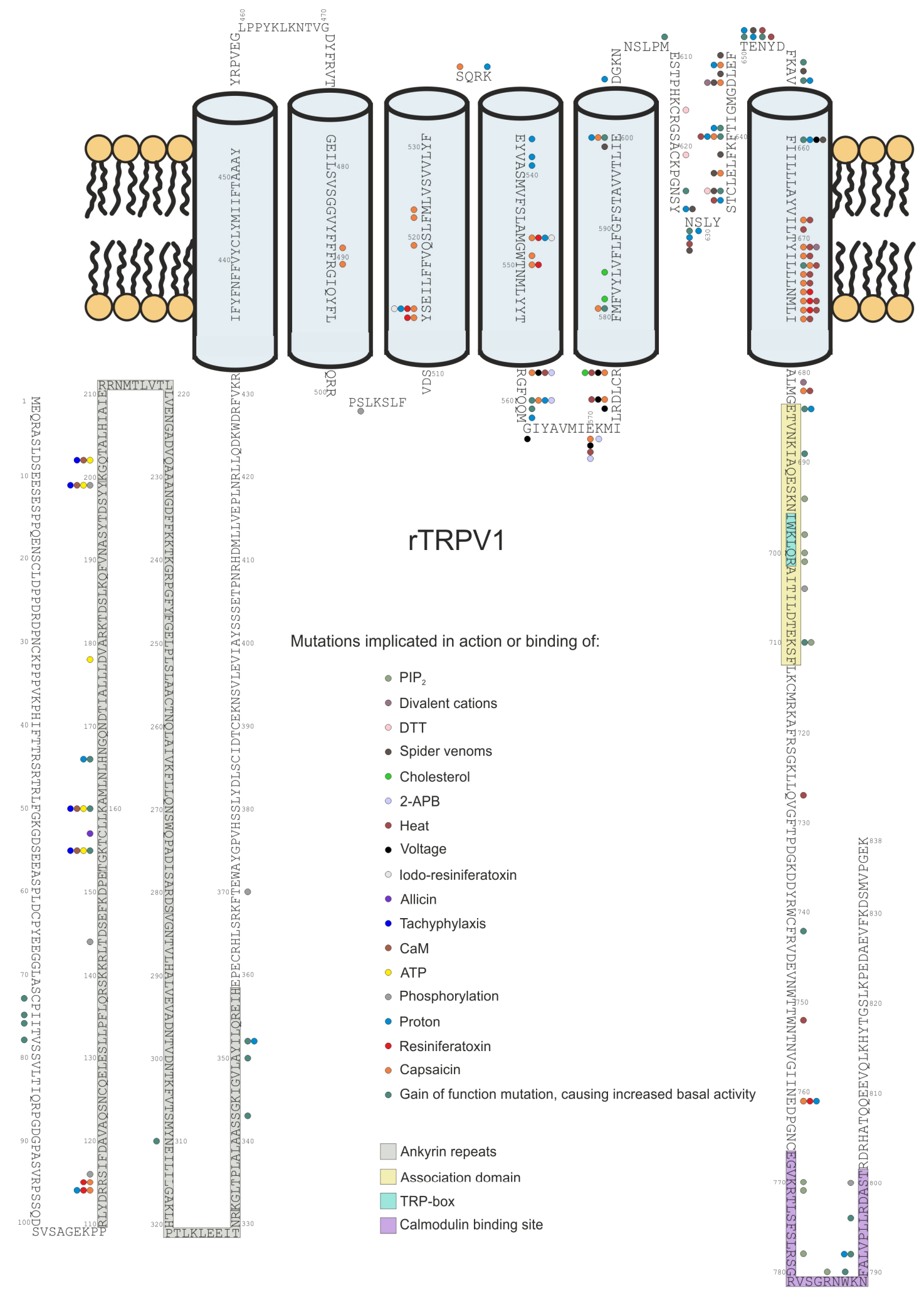

Figure 15: Summary of the mutated sites of rTRPV1

The figure summarizes the effect of 112 unique mutated sites along the rTRPV1 on the function of the channel. Coloured circles indicate the involvement of the given residue in the corresponding process. Coloured boxes show the putative location of some structural elements on the rTRPVI sequence. Sequence and region information: TRPV1_RAT (O35433) (www.uniprot.org) 


\section{Discussion}

As it is at least a thousand fold more potent analogue of CAPS, RTX applied either intrathecally or intraganglionically can execute a highly specific, TRPV1-targeted molecular neurosurgery to eliminate the cellular generator of inflammatory as well as cancer-associated pain $[76,119]$. The literature data reveal, that 24 hours after CAPS treatment a population of primary sensory neurons of both newborn [186] and adult rats [84] exhibit TUNEL staining, indicating that the neurons are killed by apoptosis. Similarly to CAPS, but with a 3-4 orders of magnitude more potent agonist activity on TRPV1, RTX can induce $\mathrm{Ca}^{2+}$ cytotoxicity and eventually ablates these neurons by rapid necrosis, followed by removal of the cell debris $[76,88,107,119]$. RTX has been shown to eliminate inflammatory pain by specific $\mathrm{Ca}^{2+}$ cytotoxicity in newborn [108] and adult rats [119], and it exerts an anti-nociceptive effect in adult mice [111], monkeys [170] and dogs [187]. A number of in vitro and in vivo experiments have validated the safety and efficacy of the molecular neurosurgery management of arthritic and cancer pain, even in large animals such as dogs and monkeys, promoting human trials and the registration of RTX as an alternative drug in pain inflammation and various neuropathy indications [170, 187]. Contrary to TRPV1 antagonists as painkillers, intraganglional or intrathecal RTX treatment provide a permanent solution to incurable chronic pain.

Moreover, we have found that RTX-treated mice also display a loss of TRPA1-dependent chemical sensitivity, confirming previous observations that TRPV1 co-expresses with TRPA1 in a number of nociceptive neurons in the PNS. The potential effect of RTX on TRPA1 is excluded by previous publications. For example, cultured DRG neurons of TRPV-/- mice did not show a stimulus-evoked rise in intracellular free $\mathrm{Ca}^{2+}$ in response to $\mathrm{RTX}$, proving that none of the remaining TRP receptors are vanilloid-sensitive [188]. Moreover, I-RTX did not interfere with DRG neuron activation in response to TRPA1 agonists [162], confirming that TRPA1 does not bind vanilloid ligands. We can conclude that RTX-mediated molecular neurosurgery additionally eliminates most or all TRPA1-containing neurons as well via TRPV1 activation, as indicated by the almost complete loss of specific immunoreactivity in sensory nociceptors. The RNA diagnostics with RT-PCR technology in DRG samples from RTX-treated and untreated rats demonstrate a significant decrease of both receptors [163]. 
The observation in these studies extend and corroborate the results of Ruparel et al. [189] that AITC can heterologously inactivate TRPV1, probably located in the same nociceptor neurons. However, Ruparel et al. interpreted their results as a consequence of TRPV1 desensitization involving signaling events. Although transient, functional desensitization based on signaling events might also be induced by low-dose vanilloids in other models [102, 110], in our case RTX treatment obviously induces the loss of both TRPV1+ and TRPA1+ neurons. As we have confirmed, the treated animals became insensitive to vanilloids for a lifetime, indicating that the mechanism is indeed deletion-, and not signaling-based. RTX-treated mice are also insensitive to AITC, which can occur only if TRPA1 expression is coincident with TRPV1 expression in the vast majority of nociceptive neurons that normally confer the pain signal to endogenous substances produced in pain and inflammation. Co-ablation of TRPV1+ neurons with TRPA1 receptors by the RTX treatment has been circumstantially verified in experiments carried out in TRPV1 knockouts. In concert with evidence here, TRPV1-/genotyped mice still express TRPA1 in their inflammatory pain sensor neurons, and therefore preserve sensitivity to AITC [190] and behave like wild-types. The neuron subtype specificity of TRPA1 was characterized in cell cultures by Story et al. [168], who noted that TRPM8 is expressed in a distinct cell population. Moreover, the vast majority of TRPA1-positive cells were co-localized with the CGRP neuropeptide, another prominent biomarker of TRPV1+ inflammatory pain-sensing neurons. With regard to these data, two markedly distinct populations of cold-responsive neurons can be distinguished: 1, TRPM8-positive neurons that lack TRPV1 and TRPA1 expression and are resistant to RTX treatment, and 2, TRPA1+ neurons that express TRPV1 as well and can be deleted with either AITC or RTX. Adult mice treated with RTX as neonates exhibited an impaired response to both CAPS and AITC in eye wipe tests and agonist-laced water consumption assays. In hot plate experiments, the response time of the treated animals was not significantly different from that of normal controls. Similar to our results, Gamse et al. have found that mice treated with CAPS as neonates demonstrated normal response times in hot plate and tail-withdrawal latency tests. In contrast, mice treated at adulthood revealed greatly prolonged latencies in both thermal sensitivity. Thus, responses to noxious chemicals in adulthood were only moderately inhibited in mice treated as newborn, but almost completely abolished if the vanilloid was administered to adults [191]. Nociceptive thresholds reported in neonatal CAPS-treated animals are 
apparently contradictory. Several groups have reported a small increase in the thermal nociceptive threshold $[171,192]$ whereas others detected little if any effect in hot plate tests [193, 194]. It has been claimed that perineural RTX selectively inhibits inflammatory hyperalgesia [195]. We have determined in serial experiments that the heat threshold increase depends on the efficacy of the RTX treatment: the heat insensitivity of the animal becomes more pronounced if RTX ablates TRPV1+ nociceptors almost completely. Chronic, repeated RTX gave the best results, while neonatal treatments were less effective. Based on comparative data collected from TRPV1-null mice (little [196] or no effect [197] in hot plate test), we can conclude that there might be additional heat receptors. The complete lack of signal transmitted by TRPV1+ neurons leads to the most complete heat insensitivity in mice lacking TRPV1+ neurons rather than the TRPV1 receptor only. Obata et al. noted that inflammation and nerve injury increase the expression of TRPA1, but not TRPM8, in DRG neurons. The occurrence of cold hyperalgesia coincided with NGF-induced up-regulation of TRPA1 in a distinct set of sensory neurons [198]. Moreover, through the intrathecal administration of an anti-sense-oligo specific for TRPA1, Katsura et al. could suppress nerveligation-induced cold hyperalgesia, but anti-TRPM8 had little or any effect [199]. In contrast with these observations, we found that not TRPA1, but TRPM8 is the main cold sensor. To explain this unexpected finding, at least two alternative hypotheses can be proposed. First, following the RTX-mediated neuronal drop-out, the intense arborization of resistant nerve endings can produce NGF, a validated exocrine transducer of gene inducer in nerve injury, which might cause the overexpression of TRPM8, a prominent cold pain signal transducer [200]. In fact, in response to inflammations and nerve injuries, the NGF expression of nociceptors and thermoceptors is known to be induced in correlation with sensitization to cold and allodynia [201, 202]. Intraplantar injection of CAPS produces a transient thermal and mechanical hyperalgesia within three to six hours, that disappears by 24 hours. Interestingly, CAPS injection upregulates proinflammatory cytokines and NGF within 1 hour, after which the cytokine levels return to the control levels [203]. However, we did not observe the upregulation of TRPM8 channel in RTX-treated mice by Western blotting or RT-PCR. In accordance with this, DRG samples from RTX-treated and untreated rats did not display a significant change at the TRPM8 level [204]. 
On the other hand, sensory stimuli are known to "compete" with each other for representation at the level of the brain. As an example, blind individuals have a better auditory ability than sighted subjects, revealing a mechanism that apparently compensates for the loss of vision [205]. Analogously, cold hypersensation might confer an imbalance in the representation of sensory stimuli signaling heat and cold at the levels of the CNS. Due to neuronal plasticity, mice treated at neonatal age can most likely compensate for the imbalance caused by that drop-out of C-type afferents neurons, while the effect of RTX treatment in adulthood can not be compensated by "fine-tuning". Importantly, our experimental data in this paper predict a shift in heat perception in humans following RTX injection, as conceptualized in the clinical trial protocol to treat severe cancer pain. Similar changes might be expected during the application of reversible, specific inhibitors of TRPV1, currently in development by different pharmaceutical companies. Such a behavioral change, however, was not obvious in cancer/arthritis patient dogs treated via the intrathecal rout of application [187], nor in monkeys targeted with this molecular neurosurgery agent at the TG [170]. Nevertheless, clinical trial of RTX in cancer pain patients may provide the answers to this question via thorough monitoring of potential changes in cold sensation, if these take place in humans at all.

After investigation of the effects caused by the deletion of the TRPV1+ neurons at the level of a whole organism, we focused on the working of the ion channel, itself.

Testing the effects of various metal cations on the vanilloid-induced activity of the TRPV1 channel, we demonstrated that $\mathrm{Mg}^{2+}, \mathrm{Mn}^{2+}$ or $\mathrm{La}^{3+}$ caused little or no decrease in channel activity, whereas $\mathrm{Zn}^{2+}$ proved to be a weak and only partial inhibitor of $2 \mu \mathrm{M}$ CAPS-induced ${ }^{45} \mathrm{Ca}^{2+}$ uptake. The other cations effectively blocked the vanilloid-induced $\mathrm{Ca}^{2+}$ entry into TRPV1/HaCaT cells, with the following sequence of potency: $\mathrm{Co}^{2+}>\mathrm{Cd}^{2+}>\mathrm{Ni}^{2+}>\mathrm{Cu}^{2+}$.

It was reported by Nilius et al. [206] that $\mathrm{Co}^{2+}$ reduced the inward $\mathrm{Ca}^{2+}$ current through ECaC1 (TRPV5), a close relative of TRPV1, sharing around 30\% homology with it. Fast and reversible recovery of the current upon washout of the inhibitor was detected during their experiments. Furthermore, they identified other $\mathrm{M}^{2+}-\mathrm{s}$ as effective inhibitors of the $\mathrm{Ca}^{2+}$ influx. Their results indicated the following overall blocking sequence: $\mathrm{Pb}^{2+}=\mathrm{Cu}^{2+}=\mathrm{Gd}^{3+}>$ $\mathrm{Cd}^{2+}>\mathrm{Zn}^{2+}>\mathrm{La}^{3+}>\mathrm{Co}^{2+}>\mathrm{Fe}^{2+}>>\mathrm{Fe}^{3+}$. Zeng et al. found $\mathrm{Cu}^{2+}$ to be a potent inhibitor of the whole-cell current evoked by intracellular ADP-ribose through TRPM2, another member of 
the TRP group. The inhibitory effect of $\mathrm{Cu}^{2+}$ was irreversible, and occurred only if $\mathrm{Cu}^{2+}$ was administered in outside-out patches, suggesting that the action site is located extracellularly. The TRPM2 current was also blocked by $\mathrm{Hg}^{2+}, \mathrm{Pb}^{2+}, \mathrm{Fe}^{2+}$ and $\mathrm{Se}^{2+}$ [207].

In accord with the above-mentioned findings, we also observed ion influx-inhibitory effects of $\mathrm{M}^{2+}$-s on the TRP channel. Depending on the TRP channel type, differences in the sequence of blocking potency could be detected. Furthermore, the blocking effects of the individual cations could be reversible or irreversible, depending on the channel type. The three channels are close relatives and share high degree of sequence and structural homology with one another, which explains the similar responses to $\mathrm{M}^{2+}$-s. Having diverged from a common ancestor, TRP channels operate on uniform principles. However, during evolution the TRP superfamily has evolved for various specialized functions. TRPV1 and TRPV5, for example, belong to different subgroups of the TRPV family; TRPV1-4 are non-ion-selective, whilst TRPV5-6 are highly $\mathrm{Ca}^{2+}$-selective. Hence, this functional adaptation may cause the differences in the $\mathrm{M}^{2+}$-evoked responses.

As concerns our own results, $\mathrm{Co}^{2+}$ reduced not only the CAPS-induced but also the heat-induced ${ }^{45} \mathrm{Ca}^{2+}$ influx. When increasing concentrations of both $\mathrm{Co}^{2+}$ and CAPS were applied, the $\mathrm{Co}^{2+}$ inhibition patterns indicated channel-blocking kinetics. Our dose-response and $\mathrm{Co}^{2+}$ accumulation experiments revealed a competition for binding sites and a co-entry mechanism. We presume that $\mathrm{Co}^{2+}$ inhibits TRPV1 through its ability to bind to the ion selectivity filter of the channel: it passes through the ion channel much more slowly than $\mathrm{Ca}^{2+} \cdot \mathrm{Ca}^{2+}$ entry is also slowed down by the binding of $\mathrm{Co}^{2+}$, which occupies the appropriate amino acid residues of the ion selectivity filter. This hypothesis seems to be further supported by the findings of Sajadi [208], who determined the stability constants of the 1:1 complexes formed between $\mathrm{M}^{2+}$ and L-tryptophan and other amino acids. The sequence obtained in the case of tryptophan was $\mathrm{Ca}^{2+}<\mathrm{Mg}^{2+}<\mathrm{Mn}^{2+}<\mathrm{Co}^{2+}<\mathrm{Ni}^{2+}<\mathrm{Cu}^{2+}>\mathrm{Zn}^{2+}$, which follows the Irving-Williams sequence [209]. The order of the stability constants was similar in the cases of methionine, alanine, leucine, valine and glycine. The amino acid sequence of the putative pore region is STSHRWRGPACRPPDSSYNSLYSTCLELFKFTIGMGD (Q8NER1, UniProt), containing all the tested amino acids but valine. The stability constants formed between $\mathrm{M}^{2+}$ and tryptophan were $\mathrm{Ca}^{2+}: 2.55 \pm 0.08 ; \mathrm{Mg}^{2+}: 2.84 \pm 0.08 ; \mathrm{Mn}^{2+}: 3.34 \pm 0.05$; $\mathrm{Co}^{2+}: 4.34 \pm 0.07 ; \mathrm{Ni}^{2+}: 5.31 \pm 0.06 ; \mathrm{Cu}^{2+}: 8.05 \pm 0.05$ and $\mathrm{Zn}^{2+}: 5.00 \pm 0.08$. The stability 
constants for $\mathrm{Mg}^{2+}$ and $\mathrm{Mn}^{2+}$ are close to that for $\mathrm{Ca}^{2+}$, so these ions can probably readily pass through the open channel of TRPV1. $\mathrm{Co}^{2+}, \mathrm{Ni}^{2+}$ and $\mathrm{Cu}^{2+}$ can be characterized by much higher complex-forming strength, shedding light on the elevated TRPV1-blocking potency. Interestingly, for these three $\mathrm{M}^{2+}$-s, an unexpected relationship can be observed between the stability constant and the TRPV1-blocking potency. The stronger the bond, the weaker the TRPV1-inhibition potency is. The ionic radii (in picometers) of these cations are $\mathrm{Ca}^{2+}: 100$; $\mathrm{Mg}^{2+}: 72 ; \mathrm{Mn}^{2+}: 67 ; \mathrm{Co}^{2+}: 65 ; \mathrm{Ni}^{2+}: 69 ; \mathrm{Cu}^{2+}: 73$ and $\mathrm{Zn}^{2+}: 74[210] . \mathrm{Ca}^{2+}$ is likely to have the ideal ionic radius and stability constant in its reactions with amino acids in order to be effectively passed along the carbonyl groups of the peptide backbone in the ion selectivity filter and the pore loop. $\mathrm{Co}^{2+}$ has a medium stability constant and the smallest ionic radius, which is probably not adequate for efficient transport. These two parameters seem to be equally involved in the appropriate ion influx. The stronger the $\mathrm{M}^{2+}$-amino acid complex and the smaller the ionic radius is, the more probable it is that $\mathrm{M}^{2+}$ will block the $\mathrm{Ca}^{2+}$ influx through the TRPV1 channel. As another interesting finding in our experiments, $\mathrm{Zn}^{2+}$ seemed to be an only weak and partial inhibitor of the ion current. Its stability constant is almost as high as that of $\mathrm{Co}^{2+}$, suggesting a strong TRPV1-blocking ability, whereas its ionic radius is much larger than that of $\mathrm{Co}^{2+}$. Interestingly, the $\mathrm{IC}_{50}$ of $\mathrm{Zn}^{2+}$ is the second lowest exceeding only that of $\mathrm{Co}^{2+}$, but $\mathrm{Zn}^{2+}$ can achieve a decrease of merely $30 \%$ of the maximal ion influx.

The TRPV1 channel is a non-selective cation channel, but still shows preference for $\mathrm{Ca}^{2+}$. The sequence of permeability is $\mathrm{Ca}^{2+}>\mathrm{Mg}^{2+}>\mathrm{Na}^{+}=\mathrm{K}^{+}=\mathrm{Cs}^{+}$[30]. In addition to all these, TRPV1 also conducts protons [211]. Following prolonged exposure to agonists, TRPV1 becomes permeable even to larger organic cations, including dyes such as YO-PRO1 and FM1-43 [178] and a lidocaine derivative QX-314 [179]. Increasing agonist concentration enhances the blocking ability of $\mathrm{Co}^{2+}$, suggesting a correlation between the increased efficacy of inhibition and the different open-state conformations of the TRPV1 channel. Further experiments (involving patch-clamp recordings) would be needed to clarify the inhibitory effect of $\mathrm{Co}^{2+}$ on the fluxes of the other cations or molecules mentioned above. However, no channel blocker or antagonist of TRPV1 has been reported that is able to block the flux of only one specific ion, and antagonists seem to block all these influxes. For example, CapZ blocks the influxes of both $\mathrm{Ca}^{2+}$ and $\mathrm{Na}^{+}$[212]. Overall, we presume that $\mathrm{Co}^{2+}$ can also block the ion currents mentioned above. 
Before the exploration of TRPV1 protein, $\mathrm{Co}^{2+}$ histochemistry was a very useful tool for the identification of vanilloid-sensitive primary afferent neurons with $\mathrm{C}$ - and A $\delta$ fibers after in vivo experiments. $\mathrm{Co}^{2+}$ uptake and the post mortem determination of $\mathrm{Co}^{2+}$ deposits quite accurately identified $\mathrm{C}$ - and $\mathrm{A} \delta$ afferents, the neuronal subset that can be activated by treatment with a vanilloid agonist, CAPS [213,214]. Likewise, as previously documented in a subpopulation of pseudo-unipolar neurons [215], we have now demonstrated selective vanilloid-induced $\mathrm{Co}^{2+}$ accumulation in the cytosol of DRG primary cultures and TRPV1transfected HaCaT and $3 \mathrm{~T} 3$ cells. The accumulation of $\mathrm{Co}^{2+}$ could be blocked by RuRed or CapZ in a dose-dependent manner. The CAPS-induced $\mathrm{Ca}^{2+}$ and $\mathrm{Co}^{2+}$ influxes in TRPV1/3T3 cells proved to be due exclusively to the TRPV1 channel and not to VGCC activity.

$\mathrm{Co}^{2+}$ inhibited the pain-evoked defensive movements in eye wipe tests in response to pungent vanilloids. However, not only TRPV1, but also some other $\mathrm{Ca}^{2+}$ channels of the sensory neurons, such as VGCCs, can be blocked by $\mathrm{Co}^{2+}$ [216]. VGCCs share structural homology with the TRPV1 channel. The $\alpha 1$ subunit of VGCCs is organized in four homologous domains (I-IV), with six transmembrane segments (S1-S6) in each [217]. There is an additional region (H5) between S5 and S6 which forms a part of the pore region of the channel [218]. Within each H5 region, there exist conserved glutamate residues, significantly homologous to conventional EF-hand motifs [219], acting as the selectivity filter [220]. $\mathrm{Mn}^{2+}, \mathrm{Ni}^{2+}$ and $\mathrm{Cd}^{2+}$, in contrast with $\mathrm{Co}^{2+}$, are known to be stronger blockers of the VGCCs. $\mathrm{Cu}^{2+}, \mathrm{Mn}^{2+}$ and $\mathrm{Co}^{2+}$ blocked high-voltage activated currents conducted by $\mathrm{Ba}^{2+}$ with $\mathrm{IC}_{50}$-s of $920 \mathrm{nM}, 58 \mu \mathrm{M}$ and $65 \mu \mathrm{M}$, respectively [221, 222]. All of these ions exert their effects through high-affinity docking to the cation-binding site at the IIIS5-H5 pore region of the VGCCs $[223,224]$. Since $\mathrm{Co}^{2+}$ has a higher $\mathrm{IC}_{50}$ for VGCCs $(\approx 65 \mu \mathrm{M})$ than for TRPV1 $(\approx 15 \mu \mathrm{M})$, we can conclude that decrease in the number of eye wipes might be due, at least partially, to an inhibitory effect of $\mathrm{Co}^{2+}$ on TRPV1.

Most painkiller drugs are competitive agonists and target the CAPS-binding domain [225]. As the ${ }^{646}$ DLEFTENYD acidic tetrad sequence of the TRPV1 receptor is unique among $\mathrm{Ca}^{2+}$ binding proteins, this permits the design of painkillers targeting the channel orifice of TRPV1 and acting as channel blockers. A deeper comprehension of the structural background and dynamics of the competition of $\mathrm{Ca}^{2+}$ with other $\mathrm{M}^{2+}$-s for entry may result in the discovery of novel channel blocker painkillers. Furthermore, our data can facilitate a more complete 
understanding of the structure and function of the TRPV1. The data depicted in Table 1 can provide a powerful tool for building an in silico model of the channel. Our experimental data may effectively contribute to the fine-tuning of the ion selectivity filter region of the model. Our results may additionally contribute to the resolution of the architecture of not only the TRPV1 but all TRP superfamily members. The specific effects of the selected $\mathrm{M}^{2+}$-s on the given ion channel pore region can serve as a valuable constraint during in silico modeling of the pore region. By comparing the different cation action profiles of the pore regions, the models can be fine-tuned. The information on the structure-function relationship of TRPV1 may promote the discovery of new, promising, more effective and safe drugs for the treatment of neurogenic inflammation and pain-related diseases and may offer new opportunities for therapeutic interventions.

\section{Summary}

The aims of this research were to determine sensory modalities that may be lost after the RTX treatment of newborn or adult mice, to dissect potential side-effect(s) of molecular neurosurgery, to gather information about the structure and function of the channel by investigating the effects of $\mathrm{M}^{2+}$ on the TRPV1 and by collecting the literature data on the functionally important point mutations of the channel for prospective in silico modeling.

The findings of the research work can be summarized as follows:

1 ,

- $\quad$ AITC had no effect on TRPV1-expressing cells.

2 ,

- Mice treated either with one dose of RTX two days post-natal, or one dose of RTX at adult age, or daily with a dose of RTX for three days at adult age completely lost their sensitivity to vanilloids and to AITC.

- Immunohistological staining and Western blotting experiments confirmed TRPV1 and TRPA1 loss in the DRG and TG of mice treated with one dose of RTX as neonates, or one dose of RTX at adult age, or daily with a dose of RTX for three days at adult age. 
- These data indicate that TRPA1 expression is coincident with TRPV1 expression in the vast majority of nociceptive neurons that normally confer pain signal to endogenous substances produced in pain and inflammation.

3 ,

- Mice treated with RTX two days post-natal and tested at the age of two months interestingly showed no change in temperature sensitivity either to heat or to cold. Due to neuronal plasticity, mice treated at neonatal age can most likely compensate for the imbalance caused by that drop-out of C-type afferents neurons.

- Mice treated with one dose of RTX at adult age become less sensitive to heat and, surprisingly, more sensitive to cold. Two hypotheses can be put forward to explain this finding: 1, The NGF-mediated overexpression of TRPM8 caused by TRPV1+ neuron loss. 2, The imbalance caused by the drop-out of C-type afferent neurons may cause alterations in the representation of sensory stimuli signaling heat and cold at the levels of the CNS.

- Mice treated daily with a dose of RTX for three days at adult age lost their heat sensitivity to a higher extent as compared with mice subjected to acute treatment, because the heat threshold increase depends on the efficacy of the RTX treatment. The heat insensitivity of the animal becomes more pronounced if RTX ablates TRPV1+ nociceptors almost completely. Chronic, repeated RTX treatment gave the best results, while neonatal treatments were less effective.

- Immunohistological staining and Western blotting experiments indicated that TRPM8+ cells remained intact in the DRG and TG of mice treated with one dose of RTX as neonates, or one dose of RTX at adult age, or daily with a dose of RTX for three days at adult age.

- On the basis of these data, two markedly distinct populations of cold-responsive neurons can be distinguished: 1, TRPM8+ neurons that lack TRPV1 and TRPA1 expression and are resistant to RTX treatment, and 2, TRPA1+ neurons that express TRPV1 as well and can be deleted with either AITC or RTX.

4 ,

- Neither $\mathrm{Mg}^{2+}, \mathrm{Mn}^{2+}$ nor $\mathrm{La}^{3+}$ significantly changed the function of TRPV1.

- $\mathrm{Zn}^{2+}$ proved to be a weak and only partial inhibitor of the CAPS-induced ${ }^{45} \mathrm{Ca}^{2+}$ uptake. 
- $\mathrm{Co}^{2+}, \mathrm{Cd}^{2+}, \mathrm{Ni}^{2+}$ and $\mathrm{Cu}^{2+}$ effectively blocked the vanilloid-induced $\mathrm{Ca}^{2+}$ entry into TRPV1/HaCaT cells, with the following sequence of potency: $\mathrm{Co}^{2+}>\mathrm{Cd}^{2+}>\mathrm{Ni}^{2+}>$ $\mathrm{Cu}^{2+}$.

- $\mathrm{Co}^{2+}$ reduced both the heat and CAPS-induced ${ }^{45} \mathrm{Ca}^{2+}$ influx to a similar extent as did RuRed, AMI or $\mathrm{R}_{4} \mathrm{~W}_{2}$.

- Increasing concentrations of $\mathrm{Co}^{2+}$ decreased only the $\mathrm{E}_{\max }$ of $\mathrm{Ca}^{2+}$ entry in a vanilloidinduced ${ }^{45} \mathrm{Ca}^{2+}$-uptake assay; the affinity of CAPS for TRPV1 did not change. $\mathrm{Co}^{2+}$ inhibition patterns indicated channel-blocking kinetics.

- Increasing cold $\mathrm{Ca}^{2+}$ concentration, in a vanilloid-induced ${ }^{45} \mathrm{Ca}^{2+}$-uptake assay, decreased the inhibitory effect of $\mathrm{Co}^{2+}$, showing that the effect of $\mathrm{Co}^{2+}$ on $\mathrm{Ca}^{2+}$ entry mainly depends on the competition for entry sites.

- Increasing CAPS concentration in a vanilloid-induced ${ }^{45} \mathrm{Ca}^{2+}$-uptake assay, caused a shift in the $\mathrm{IC}_{50}$ of $\mathrm{Co}^{2+}$, increasing agonist concentration enhancing the blocking ability of $\mathrm{Co}^{2+}$, suggesting that the increased efficiency of inhibition correlates with the different open-state conformations of the TRPV1 channel.

- We presume that the efficacy of the TRPV1 blocking effect caused by $\mathrm{M}^{2+}$ is determined by the combined impact of the ionic radii of the $\mathrm{M}^{2+}$ and the stability constants of the complexes formed between $\mathrm{M}^{2+}$ and amino acids. $\mathrm{Ca}^{2+}$ is likely to have the ideal ionic radius and stability constant in its reactions with amino acids in order to be effectively passed along the carbonyl groups of the peptide backbone in the ion selectivity filter and the pore loop. The stronger the $\mathrm{M}^{2+}$-amino acid complex and the smaller the ionic radius is, the more probable it is that $\mathrm{M}^{2+}$ will block the $\mathrm{Ca}^{2+}$ influx through the TRPV1 channel.

- $\left(\mathrm{NH}_{4}\right)_{\mathrm{n}} \mathrm{S}_{\mathrm{x}}$ histochemistry experiments on rTRPV1/HaCaT and rTRPV1/3T3 cell lines and sensory neuron cultures prepared from DRGs of rat embryos revealed that $\mathrm{Co}^{2+}$ not only competes with $\mathrm{Ca}^{2+}$, but also enters into the cytosol of TRPV1+ cells, through the TRPV1 channel.

- $\left(\mathrm{NH}_{4}\right)_{\mathrm{n}} \mathrm{S}_{\mathrm{x}}$ histochemistry experiments following extracellular $\mathrm{KCl}$ exposure of rTRPV1/3T3 cells ruled out the role of VGCCs in $\mathrm{Co}^{2+}$ accumulation.

- $\mathrm{Co}^{2+}$ decreased the frequency of vanilloid-evoked defending movements in tests of eye wiping. 
5 ,

- An overview of the currently available results of site-directed mutagenesis studies on TRPV1 receptor was created and published [185] containing summarized information on 112 unique mutated sites along the TRPV1. The mutations influence the effects or binding of different agonists, antagonists, and channel blockers, alter the responsiveness to heat, acid, and voltage dependence, affect the channel pore characteristics, and influence the regulation of the receptor function by phosphorylation, glycosylation, CaM, PIP2, ATP and lipid binding. 


\section{Acknowledgement}

First of all I wish to express my deep gratitude to my supervisors, Dr. Gerda Szakonyi, Prof. Dr. György Dombi and Dr. Zoltán Oláh, for their guidance and encouragement, especially during the more challenging moments of my work.

I would like to thank Katalin Jósvay and Csaba Vizler for their generous help and advice in the experimental work, and for critically reviewing the manuscript.

I express my special thanks to Erzsébet Kusz for her supportive help and useful advice in the tissue culture laboratory.

I would also like to thank all of my co-authors and colleagues in the Institute of Pharmaceutical Analysis and in the Institute of the Biochemistry of Biological Research Centre of the Hungarian Academy of Sciences for their kind collaboration.

I am deeply grateful to my family and friends for their patience and love.

\section{Financial support}

This work was supported by grants from the National Office for Research and Technology (OMFB-01630; OMFB-01703, OMFB-01576/2006, BAROSS_DA07-DA_TECH_07-20080043 and ERC_09_HU 3D_TRPV1). The Project named "TÁMOP-4.2.1/B-09/1/KONV2010-0005-Creating the Center of Excellence at the University of Szeged" was supported by the European Union and co-financed by the European Regional Development Fund. 


\section{References}

1. Clapham DE: TRP channels as cellular sensors. Nature 2003, 426:517-524.

2. Szallasi A, Cortright DN, Blum CA, Eid SR: The vanilloid receptor TRPV1: 10 years from channel cloning to antagonist proof-of-concept. Nat Rev Drug Discov 2007, 6:357-372.

3. Fernandez-Ballester G, Ferrer-Montiel A: Molecular modeling of the full-length human TRPV1 channel in closed and desensitized states. J Membr Biol 2008, 223:161-172.

4. Carlson AE, Westenbroek RE, Quill T, Ren D, Clapham DE, Hille B, Garbers DL, Babcock DF: CatSper1 required for evoked Ca2+ entry and control of flagellar function in sperm. Proc Natl Acad Sci U S A 2003, 100:14864-14868.

5. Cosens DJ, Manning A: Abnormal electroretinogram from a Drosophila mutant. Nature 1969, 224:285-287.

6. O'Neill J, Brock C, Olesen AE, Andresen T, Nilsson M, Dickenson AH: Unravelling the mystery of capsaicin: a tool to understand and treat pain. Pharmacol Rev 2012, 64:939-971.

7. Venkatachalam K, Montell C: TRP channels. Annu Rev Biochem 2007, 76:387-417.

8. Owsianik G, Talavera K, Voets T, Nilius B: Permeation and selectivity of TRP channels. Annu Rev Physiol 2006, 68:685-717.

9. Li M, Yu Y, Yang J: Structural biology of TRP channels. Adv Exp Med Biol 2011, 704:1-23.

10. Landry Y, Gies JP: Drugs and their molecular targets: an updated overview. Fundam Clin Pharmacol 2008, 22:1-18.

11. Okuhara DY, Hsia AY, Xie M: Transient receptor potential channels as drug targets. Expert Opin Ther Targets 2007, 11:391-401.

12. Nilius B, Vennekens R: TRP Channels and Human Diseases. In Vanilloid Receptor TRPV1 in Drug Discovery: Targeting Pain and Other Pathological Disorders. Edited by Gomtsyan A, Faltynek CR: John Wiley \& Sons, Inc., Hoboken, NJ, USA.; 2010

13. Xu SZ, Zeng F, Boulay G, Grimm C, Harteneck C, Beech DJ: Block of TRPC5 channels by 2-aminoethoxydiphenyl borate: a differential, extracellular and voltage-dependent effect. Br J Pharmacol 2005, 145:405-414.

14. Jin X, Touhey J, Gaudet R: Structure of the N-terminal ankyrin repeat domain of the TRPV2 ion channel. J Biol Chem 2006, 281:25006-25010.

15. McCleverty CJ, Koesema E, Patapoutian A, Lesley SA, Kreusch A: Crystal structure of the human TRPV2 channel ankyrin repeat domain. Protein Sci 2006, 15:22012206.

16. Lishko PV, Procko E, Jin X, Phelps CB, Gaudet R: The ankyrin repeats of TRPV1 bind multiple ligands and modulate channel sensitivity. Neuron 2007, 54:905-918.

17. Hellwig N, Albrecht N, Harteneck C, Schultz G, Schaefer M: Homo- and heteromeric assembly of TRPV channel subunits. $J$ Cell Sci 2005, 118:917-928.

18. Jung J, Lee SY, Hwang SW, Cho H, Shin J, Kang YS, Kim S, Oh U: Agonist recognition sites in the cytosolic tails of vanilloid receptor $1 . \mathrm{J} \mathrm{Biol} \mathrm{Chem} \mathrm{2002,}$ 277:44448-44454.

19. Mosavi LK, Cammett TJ, Desrosiers DC, Peng ZY: The ankyrin repeat as molecular architecture for protein recognition. Protein Sci 2004, 13:1435-1448. 
20. Sedgwick SG, Smerdon SJ: The ankyrin repeat: a diversity of interactions on a common structural framework. Trends Biochem Sci 1999, 24:311-316.

21. Vennekens R, Hoenderop JG, Prenen J, Stuiver M, Willems PH, Droogmans G, Nilius $\mathrm{B}$, Bindels RJ: Permeation and gating properties of the novel epithelial $\mathbf{C a}(2+)$ channel. $J$ Biol Chem 2000, 275:3963-3969.

22. Yue L, Peng JB, Hediger MA, Clapham DE: CaT1 manifests the pore properties of the calcium-release-activated calcium channel. Nature 2001, 410:705-709.

23. Dhaka A, Viswanath V, Patapoutian A: Trp ion channels and temperature sensation. Annu Rev Neurosci 2006, 29:135-161.

24. Lawson JJ, McIlwrath SL, Woodbury CJ, Davis BM, Koerber HR: TRPV1 unlike TRPV2 is restricted to a subset of mechanically insensitive cutaneous nociceptors responding to heat. $J$ Pain 2008, 9:298-308.

25. Xu H, Delling M, Jun JC, Clapham DE: Oregano, thyme and clove-derived flavors and skin sensitizers activate specific TRP channels. Nat Neurosci 2006, 9:628-635.

26. Moqrich A, Hwang SW, Earley TJ, Petrus MJ, Murray AN, Spencer KS, Andahazy M, Story GM, Patapoutian A: Impaired thermosensation in mice lacking TRPV3, a heat and camphor sensor in the skin. Science 2005, 307:1468-1472.

27. Nilius B, Owsianik G, Voets T, Peters JA: Transient receptor potential cation channels in disease. Physiol Rev 2007, 87:165-217.

28. Hoenderop JG, van der Kemp AW, Hartog A, van de Graaf SF, van Os CH, Willems PH, Bindels RJ: Molecular identification of the apical Ca2+ channel in 1, 25dihydroxyvitamin D3-responsive epithelia. J Biol Chem 1999, 274:8375-8378.

29. Peng JB, Chen XZ, Berger UV, Vassilev PM, Tsukaguchi H, Brown EM, Hediger MA: Molecular cloning and characterization of a channel-like transporter mediating intestinal calcium absorption. J Biol Chem 1999, 274:22739-22746.

30. Caterina MJ, Schumacher MA, Tominaga M, Rosen TA, Levine JD, Julius D: The capsaicin receptor: a heat-activated ion channel in the pain pathway. Nature 1997, 389:816-824.

31. Kedei N, Szabo T, Lile JD, Treanor JJ, Olah Z, Iadarola MJ, Blumberg PM: Analysis of the native quaternary structure of vanilloid receptor 1. J Biol Chem 2001, 276:28613-28619.

32. Moiseenkova-Bell VY, Stanciu LA, Serysheva, II, Tobe BJ, Wensel TG: Structure of TRPV1 channel revealed by electron cryomicroscopy. Proc Natl Acad Sci U S A 2008, 105:7451-7455.

33. Vriens J, Appendino G, Nilius B: Pharmacology of vanilloid transient receptor potential cation channels. Mol Pharmacol 2009, 75:1262-1279.

34. Szallasi A, Blumberg PM: Resiniferatoxin, a phorbol-related diterpene, acts as an ultrapotent analog of capsaicin, the irritant constituent in red pepper. Neuroscience 1989, 30:515-520.

35. Hergenhahn M, Kusumoto S, Hecker E: On the active principles of the spurge family (Euphorbiaceae). V. Extremely skin-irritant and moderately tumorpromoting diterpene esters from Euphorbia resinifera Berg. $J$ Cancer Res Clin Oncol 1984, 108:98-109.

36. Szallasi A: The vanilloid (capsaicin) receptor: receptor types and species differences. Gen Pharmacol 1994, 25:223-243. 
37. Witte DG, Cassar SC, Masters JN, Esbenshade T, Hancock AA: Use of a fluorescent imaging plate reader--based calcium assay to assess pharmacological differences between the human and rat vanilloid receptor. J Biomol Screen 2002, 7:466-475.

38. Culshaw AJ, Bevan S, Christiansen M, Copp P, Davis A, Davis C, Dyson A, Dziadulewicz EK, Edwards L, Eggelte $\mathrm{H}$, et al: Identification and biological characterization of 6-aryl-7-isopropylquinazolinones as novel TRPV1 antagonists that are effective in models of chronic pain. $J$ Med Chem 2006, 49:471-474.

39. Pearce LV, Petukhov PA, Szabo T, Kedei N, Bizik F, Kozikowski AP, Blumberg PM: Evodiamine functions as an agonist for the vanilloid receptor TRPV1. Org Biomol Chem 2004, 2:2281-2286.

40. $\mathrm{Xu} \mathrm{S}$, Cheng Y, Keast JR, Osborne PB: 17beta-estradiol activates estrogen receptor beta-signalling and inhibits transient receptor potential vanilloid receptor 1 activation by capsaicin in adult rat nociceptor neurons. Endocrinology 2008, 149:5540-5548.

41. De Petrocellis L, Bisogno T, Davis JB, Pertwee RG, Di Marzo V: Overlap between the ligand recognition properties of the anandamide transporter and the VR1 vanilloid receptor: inhibitors of anandamide uptake with negligible capsaicin-like activity. FEBS Lett 2000, 483:52-56.

42. Ross RA: Anandamide and vanilloid TRPV1 receptors. Br J Pharmacol 2003, 140:790-801.

43. Ahern GP: Activation of TRPV1 by the satiety factor oleoylethanolamide. $J$ Biol Chem 2003, 278:30429-30434.

44. Hwang SW, Cho H, Kwak J, Lee SY, Kang CJ, Jung J, Cho S, Min KH, Suh YG, Kim $\mathrm{D}$, Oh U: Direct activation of capsaicin receptors by products of lipoxygenases: endogenous capsaicin-like substances. Proc Natl Acad Sci U S A 2000, 97:61556160 .

45. Jordt SE, Tominaga M, Julius D: Acid potentiation of the capsaicin receptor determined by a key extracellular site. Proc Natl Acad Sci U S A 2000, 97:81348139.

46. Szallasi A, Blumberg PM: Vanilloid (Capsaicin) receptors and mechanisms. Pharmacol Rev 1999, 51:159-212.

47. Yang BH, Piao ZG, Kim YB, Lee CH, Lee JK, Park K, Kim JS, Oh SB: Activation of vanilloid receptor 1 (VR1) by eugenol. $J$ Dent Res 2003, 82:781-785.

48. Jara-Oseguera A, Simon SA, Rosenbaum T: TRPV1: on the road to pain relief. Curr Mol Pharmacol 2008, 1:255-269.

49. Premkumar LS, Qi ZH, Van Buren J, Raisinghani M: Enhancement of potency and efficacy of NADA by PKC-mediated phosphorylation of vanilloid receptor. $J$ Neurophysiol 2004, 91:1442-1449.

50. Price TJ, Patwardhan A, Akopian AN, Hargreaves KM, Flores CM: Modulation of trigeminal sensory neuron activity by the dual cannabinoid-vanilloid agonists anandamide, $\mathbf{N}$-arachidonoyl-dopamine and arachidonyl-2-chloroethylamide. $\mathrm{Br}$ J Pharmacol 2004, 141:1118-1130.

51. Suh YG, Oh U: Activation and activators of TRPV1 and their pharmaceutical implication. Curr Pharm Des 2005, 11:2687-2698.

52. Liu L, Simon SA: Similarities and differences in the currents activated by capsaicin, piperine, and zingerone in rat trigeminal ganglion cells. $J$ Neurophysiol 1996, 76:1858-1869. 
53. McNamara FN, Randall A, Gunthorpe MJ: Effects of piperine, the pungent component of black pepper, at the human vanilloid receptor (TRPV1). $\mathrm{Br} J$ Pharmacol 2005, 144:781-790.

54. Dedov VN, Tran VH, Duke CC, Connor M, Christie MJ, Mandadi S, Roufogalis BD: Gingerols: a novel class of vanilloid receptor (VR1) agonists. Br J Pharmacol 2002, 137:793-798.

55. Iwasaki Y, Morita A, Iwasawa T, Kobata K, Sekiwa Y, Morimitsu Y, Kubota K, Watanabe T: A nonpungent component of steamed ginger--[10]-shogaol--increases adrenaline secretion via the activation of TRPV1. Nutr Neurosci 2006, 9:169-178.

56. Jung J, Hwang SW, Kwak J, Lee SY, Kang CJ, Kim WB, Kim D, Oh U: Capsaicin binds to the intracellular domain of the capsaicin-activated ion channel. $J$ Neurosci 1999, 19:529-538.

57. Bootman MD, Collins TJ, Mackenzie L, Roderick HL, Berridge MJ, Peppiatt CM: 2aminoethoxydiphenyl borate (2-APB) is a reliable blocker of store-operated $\mathrm{Ca} 2+$ entry but an inconsistent inhibitor of InsP3-induced Ca2+ release. FASEB J 2002, 16:1145-1150.

58. Bautista DM, Jordt SE, Nikai T, Tsuruda PR, Read AJ, Poblete J, Yamoah EN, Basbaum AI, Julius D: TRPA1 mediates the inflammatory actions of environmental irritants and proalgesic agents. Cell 2006, 124:1269-1282.

59. Macpherson LJ, Geierstanger BH, Viswanath V, Bandell M, Eid SR, Hwang S, Patapoutian A: The pungency of garlic: activation of TRPA1 and TRPV1 in response to allicin. Curr Biol 2005, 15:929-934.

60. Szolcsanyi J, Sandor Z: Multisteric TRPV1 nocisensor: a target for analgesics. Trends Pharmacol Sci 2012, 33:646-655.

61. Dray A, Bettaney J, Forster P: Resiniferatoxin, a potent capsaicin-like stimulator of peripheral nociceptors in the neonatal rat tail in vitro. $\mathrm{Br} J$ Pharmacol 1990, 99:323-326.

62. Docherty RJ, Yeats JC, Piper AS: Capsazepine block of voltage-activated calcium channels in adult rat dorsal root ganglion neurones in culture. Br J Pharmacol 1997, 121:1461-1467.

63. Liu L, Simon SA: Capsazepine, a vanilloid receptor antagonist, inhibits nicotinic acetylcholine receptors in rat trigeminal ganglia. Neurosci Lett 1997, 228:29-32.

64. Xia R, Dekermendjian K, Lullau E, Dekker N: TRPV1: a therapy target that attracts the pharmaceutical interests. Adv Exp Med Biol 2011, 704:637-665.

65. Seabrook GR, Sutton KG, Jarolimek W, Hollingworth GJ, Teague S, Webb J, Clark N, Boyce S, Kerby J, Ali Z, et al: Functional properties of the high-affinity TRPV1 (VR1) vanilloid receptor antagonist (4-hydroxy-5-iodo-3-methoxyphenylacetate ester) iodo-resiniferatoxin. $J$ Pharmacol Exp Ther 2002, 303:1052-1060.

66. Planells-Cases R, Aracil A, Merino JM, Gallar J, Perez-Paya E, Belmonte C, Gonzalez-Ros JM, Ferrer-Montiel AV: Arginine-rich peptides are blockers of VR-1 channels with analgesic activity. FEBS Lett 2000, 481:131-136.

67. Himmel HM, Kiss T, Borvendeg SJ, Gillen C, Illes P: The arginine-rich hexapeptide R4W2 is a stereoselective antagonist at the vanilloid receptor 1: a $\mathrm{Ca2}+$ imaging study in adult rat dorsal root ganglion neurons. $J$ Pharmacol Exp Ther 2002, 301:981-986.

68. Gavva NR: Body-temperature maintenance as the predominant function of the vanilloid receptor TRPV1. Trends Pharmacol Sci 2008, 29:550-557. 
69. Gavva NR, Bannon AW, Surapaneni S, Hovland DN, Jr., Lehto SG, Gore A, Juan T, Deng $\mathrm{H}$, Han $\mathrm{B}$, Klionsky $\mathrm{L}$, et al: The vanilloid receptor TRPV1 is tonically activated in vivo and involved in body temperature regulation. $J$ Neurosci 2007, 27:3366-3374.

70. Gavva NR, Treanor JJ, Garami A, Fang L, Surapaneni S, Akrami A, Alvarez F, Bak A, Darling M, Gore A, et al: Pharmacological blockade of the vanilloid receptor TRPV1 elicits marked hyperthermia in humans. Pain 2008, 136:202-210.

71. Wang S, Poon K, Oswald RE, Chuang HH: Distinct modulations of human capsaicin receptor by protons and magnesium through different domains. $J$ Biol Chem 2010, 285:11547-11556.

72. Voets T, Droogmans G, Wissenbach U, Janssens A, Flockerzi V, Nilius B: The principle of temperature-dependent gating in cold- and heat-sensitive TRP channels. Nature 2004, 430:748-754.

73. Ma W, Quirion R: Inflammatory mediators modulating the transient receptor potential vanilloid 1 receptor: therapeutic targets to treat inflammatory and neuropathic pain. Expert Opin Ther Targets 2007, 11:307-320.

74. Rosenbaum T, Simon SA: TRPV1 Receptors and Signal Transduction. 2007.

75. Tominaga M, Caterina MJ, Malmberg AB, Rosen TA, Gilbert H, Skinner K, Raumann $\mathrm{BE}$, Basbaum AI, Julius D: The cloned capsaicin receptor integrates multiple painproducing stimuli. Neuron 1998, 21:531-543.

76. Olah Z, Szabo T, Karai L, Hough C, Fields RD, Caudle RM, Blumberg PM, Iadarola $\mathrm{MJ}$ : Ligand-induced dynamic membrane changes and cell deletion conferred by vanilloid receptor 1. J Biol Chem 2001, 276:11021-11030.

77. Sprague J, Harrison C, Rowbotham DJ, Smart D, Lambert DG: Temperaturedependent activation of recombinant rat vanilloid VR1 receptors expressed in HEK293 cells by capsaicin and anandamide. Eur J Pharmacol 2001, 423:121-125.

78. De Petrocellis L, Harrison S, Bisogno T, Tognetto M, Brandi I, Smith GD, Creminon C, Davis JB, Geppetti P, Di Marzo V: The vanilloid receptor (VR1)-mediated effects of anandamide are potently enhanced by the cAMP-dependent protein kinase. $J$ Neurochem 2001, 77:1660-1663.

79. Rathee PK, Distler C, Obreja O, Neuhuber W, Wang GK, Wang SY, Nau C, Kress M: PKA/AKAP/VR-1 module: A common link of Gs-mediated signaling to thermal hyperalgesia. $J$ Neurosci 2002, 22:4740-4745.

80. Vlachova V, Teisinger J, Susankova K, Lyfenko A, Ettrich R, Vyklicky L: Functional role of C-terminal cytoplasmic tail of rat vanilloid receptor 1. J Neurosci 2003, 23:1340-1350.

81. Bhave G, Hu HJ, Glauner KS, Zhu W, Wang H, Brasier DJ, Oxford GS, Gereau RWt: Protein kinase $\mathrm{C}$ phosphorylation sensitizes but does not activate the capsaicin receptor transient receptor potential vanilloid 1 (TRPV1). Proc Natl Acad Sci US A 2003, 100:12480-12485.

82. Zhang X, Du XN, Zhang GH, Jia ZF, Chen XJ, Huang DY, Liu BY, Zhang HL: Agonist-dependent potentiation of vanilloid receptor transient receptor potential vanilloid type 1 function by stilbene derivatives. Mol Pharmacol 2012, 81:689-700.

83. Tominaga M, Wada M, Masu M: Potentiation of capsaicin receptor activity by metabotropic ATP receptors as a possible mechanism for ATP-evoked pain and hyperalgesia. Proc Natl Acad Sci U S A 2001, 98:6951-6956. 
84. Varga A, Bolcskei K, Szoke E, Almasi R, Czeh G, Szolcsanyi J, Petho G: Relative roles of protein kinase $A$ and protein kinase $C$ in modulation of transient receptor potential vanilloid type 1 receptor responsiveness in rat sensory neurons in vitro and peripheral nociceptors in vivo. Neuroscience 2006, 140:645-657.

85. Olah $\mathrm{Z}$, Karai L, Iadarola MJ: Protein kinase C(alpha) is required for vanilloid receptor 1 activation. Evidence for multiple signaling pathways. $\mathrm{J}$ Biol Chem 2002, 277:35752-35759.

86. Wang Y, Kedei N, Wang M, Wang QJ, Huppler AR, Toth A, Tran R, Blumberg PM: Interaction between protein kinase $\mathrm{Cmu}$ and the vanilloid receptor type 1 . J Biol Chem 2004, 279:53674-53682.

87. Jung J, Shin JS, Lee SY, Hwang SW, Koo J, Cho H, Oh U: Phosphorylation of vanilloid receptor 1 by $\mathrm{Ca} 2+/$ calmodulin-dependent kinase II regulates its vanilloid binding. $J$ Biol Chem 2004, 279:7048-7054.

88. Jin X, Morsy N, Winston J, Pasricha PJ, Garrett K, Akbarali HI: Modulation of TRPV1 by nonreceptor tyrosine kinase, c-Src kinase. Am J Physiol Cell Physiol 2004, 287:C558-563.

89. Docherty RJ, Yeats JC, Bevan S, Boddeke HW: Inhibition of calcineurin inhibits the desensitization of capsaicin-evoked currents in cultured dorsal root ganglion neurones from adult rats. Pflugers Arch 1996, 431:828-837.

90. Koplas PA, Rosenberg RL, Oxford GS: The role of calcium in the desensitization of capsaicin responses in rat dorsal root ganglion neurons. J Neurosci 1997, 17:35253537.

91. Prescott ED, Julius D: A modular PIP2 binding site as a determinant of capsaicin receptor sensitivity. Science 2003, 300:1284-1288.

92. Liu $B$, Zhang $C$, Qin $F$ : Functional recovery from desensitization of vanilloid receptor TRPV1 requires resynthesis of phosphatidylinositol 4,5-bisphosphate. $J$ Neurosci 2005, 25:4835-4843.

93. Stein AT, Ufret-Vincenty CA, Hua L, Santana LF, Gordon SE: Phosphoinositide 3kinase binds to TRPV1 and mediates NGF-stimulated TRPV1 trafficking to the plasma membrane. J Gen Physiol 2006, 128:509-522.

94. Ufret-Vincenty CA, Klein RM, Hua L, Angueyra J, Gordon SE: Localization of the PIP2 sensor of TRPV1 ion channels. J Biol Chem 2011, 286:9688-9698.

95. Yao J, Qin F: Interaction with phosphoinositides confers adaptation onto the TRPV1 pain receptor. PLoS Biol 2009, 7:e46.

96. Levitan I, Fang Y, Rosenhouse-Dantsker A, Romanenko V: Cholesterol and ion channels. Subcell Biochem 2010, 51:509-549.

97. Levitan I, Christian AE, Tulenko TN, Rothblat GH: Membrane cholesterol content modulates activation of volume-regulated anion current in bovine endothelial cells. J Gen Physiol 2000, 115:405-416.

98. Levitan I: Cholesterol and Kir channels. IUBMB Life 2009, 61:781-790.

99. Liu M, Huang W, Wu D, Priestley JV: TRPV1, but not P2X, requires cholesterol for its function and membrane expression in rat nociceptors. Eur J Neurosci 2006, 24:1-6.

100. Szoke E, Borzsei R, Toth DM, Lengl O, Helyes Z, Sandor Z, Szolcsanyi J: Effect of lipid raft disruption on TRPV1 receptor activation of trigeminal sensory neurons and transfected cell line. Eur J Pharmacol 2010, 628:67-74. 
101. Santha P, Oszlacs O, Dux M, Dobos I, Jancso G: Inhibition of glucosylceramide synthase reversibly decreases the capsaicin-induced activation and TRPV1 expression of cultured dorsal root ganglion neurons. Pain 2010, 150:103-112.

102. Numazaki M, Tominaga T, Takeuchi K, Murayama N, Toyooka H, Tominaga M: Structural determinant of TRPV1 desensitization interacts with calmodulin. Proc Natl Acad Sci U S A 2003, 100:8002-8006.

103. Rosenbaum T, Gordon-Shaag A, Munari M, Gordon SE: Ca2+/calmodulin modulates TRPV1 activation by capsaicin. J Gen Physiol 2004, 123:53-62.

104. Vyklicky L, Novakova-Tousova K, Benedikt J, Samad A, Touska F, Vlachova V: Calcium-dependent desensitization of vanilloid receptor TRPV1: a mechanism possibly involved in analgesia induced by topical application of capsaicin. Physiol Res 2008, 57 Suppl 3:S59-68.

105. Vellani V, Mapplebeck S, Moriondo A, Davis JB, McNaughton PA: Protein kinase C activation potentiates gating of the vanilloid receptor VR1 by capsaicin, protons, heat and anandamide. $J$ Physiol 2001, 534:813-825.

106. Susankova K, Tousova K, Vyklicky L, Teisinger J, Vlachova V: Reducing and oxidizing agents sensitize heat-activated vanilloid receptor (TRPV1) current. $\mathrm{Mol}$ Pharmacol 2006, 70:383-394.

107. Cesare P, Dekker LV, Sardini A, Parker PJ, McNaughton PA: Specific involvement of PKC-epsilon in sensitization of the neuronal response to painful heat. Neuron 1999, 23:617-624.

108. Premkumar LS, Ahern GP: Induction of vanilloid receptor channel activity by protein kinase C. Nature 2000, 408:985-990.

109. Chuang HH, Prescott ED, Kong H, Shields S, Jordt SE, Basbaum AI, Chao MV, Julius D: Bradykinin and nerve growth factor release the capsaicin receptor from PtdIns(4,5)P2-mediated inhibition. Nature 2001, 411:957-962.

110. Bhave G, Zhu W, Wang H, Brasier DJ, Oxford GS, Gereau RWt: cAMP-dependent protein kinase regulates desensitization of the capsaicin receptor (VR1) by direct phosphorylation. Neuron 2002, 35:721-731.

111. Shin HJ, Gye MH, Chung KH, Yoo BS: Activity of protein kinase C modulates the apoptosis induced by polychlorinated biphenyls in human leukemic HL-60 cells. Toxicol Lett 2002, 135:25-31.

112. Bevan S, Andersson DA: TRP channel antagonists for pain--opportunities beyond TRPV1. Curr Opin Investig Drugs 2009, 10:655-663.

113. Cortright DN, Szallasi A: TRP channels and pain. Curr Pharm Des 2009, 15:17361749.

114. Stucky CL, Dubin AE, Jeske NA, Malin SA, McKemy DD, Story GM: Roles of transient receptor potential channels in pain. Brain Res Rev 2009, 60:2-23.

115. Fernandes ES, Russell FA, Spina D, McDougall JJ, Graepel R, Gentry C, Staniland AA, Mountford DM, Keeble JE, Malcangio M, et al: A distinct role for transient receptor potential ankyrin 1 , in addition to transient receptor potential vanilloid 1 , in tumor necrosis factor alpha-induced inflammatory hyperalgesia and Freund's complete adjuvant-induced monarthritis. Arthritis Rheum 2011, 63:819829.

116. Fernandes ES, Fernandes MA, Keeble JE: The functions of TRPA1 and TRPV1: moving away from sensory nerves. Br J Pharmacol 2012, 166:510-521. 
117. Alawi K, Keeble $\mathrm{J}$ : The paradoxical role of the transient receptor potential vanilloid 1 receptor in inflammation. Pharmacol Ther 2010, 125:181-195.

118. Dux M, Santha P, Jancso G: The role of chemosensitive afferent nerves and TRP ion channels in the pathomechanism of headaches. Pflugers Arch 2012, 464:239248.

119. Karai L, Brown DC, Mannes AJ, Connelly ST, Brown J, Gandal M, Wellisch OM, Neubert JK, Olah Z, Iadarola MJ: Deletion of vanilloid receptor 1-expressing primary afferent neurons for pain control. J Clin Invest 2004, 113:1344-1352.

120. Szabo T, Olah Z, Iadarola MJ, Blumberg PM: Epidural resiniferatoxin induced prolonged regional analgesia to pain. Brain Res 1999, 840:92-98.

121. Zhou HY, Zhang HM, Chen SR, Pan HL: Increased nociceptive input rapidly modulates spinal GABAergic transmission through endogenously released glutamate. J Neurophysiol 2007, 97:871-882.

122. Caudle RM, Karai L, Mena N, Cooper BY, Mannes AJ, Perez FM, Iadarola MJ, Olah $\mathrm{Z}$ : Resiniferatoxin-induced loss of plasma membrane in vanilloid receptor expressing cells. Neurotoxicology 2003, 24:895-908.

123. Resiniferatoxin to Treat Severe Pain Associated With Advanced Cancer [http://clinicaltrials.gov/ct2/show/NCT00804154?term=resiniferatoxin\&rank=1]

124. Jin K, Xie L, Kim SH, Parmentier-Batteur S, Sun Y, Mao XO, Childs J, Greenberg DA: Defective adult neurogenesis in CB1 cannabinoid receptor knockout mice. Mol Pharmacol 2004, 66:204-208.

125. Jancso-Gabor A, Szolcsanyi J, Jancso N: Stimulation and desensitization of the hypothalamic heat-sensitive structures by capsaicin in rats. $J$ Physiol 1970, 208:449-459.

126. Jancso G, Wollemann M: The effect of capsaicin on the adenylate cyclase activity of rat brain. Brain Res 1977, 123:323-329.

127. Dib B: Effects of intracerebroventricular capsaicin on thermoregulatory behavior in the rat. Pharmacol Biochem Behav 1982, 16:23-27.

128. Steiner AA, Turek VF, Almeida MC, Burmeister JJ, Oliveira DL, Roberts JL, Bannon AW, Norman MH, Louis JC, Treanor JJ, et al: Nonthermal activation of transient receptor potential vanilloid-1 channels in abdominal viscera tonically inhibits autonomic cold-defense effectors. $J$ Neurosci 2007, 27:7459-7468.

129. Gavva NR, Bannon AW, Hovland DN, Jr., Lehto SG, Klionsky L, Surapaneni S, Immke DC, Henley C, Arik L, Bak A, et al: Repeated administration of vanilloid receptor TRPV1 antagonists attenuates hyperthermia elicited by TRPV1 blockade. J Pharmacol Exp Ther 2007, 323:128-137.

130. Tamayo N, Liao H, Stec MM, Wang X, Chakrabarti P, Retz D, Doherty EM, Surapaneni S, Tamir R, Bannon AW, et al: Design and synthesis of peripherally restricted transient receptor potential vanilloid 1 (TRPV1) antagonists. $J$ Med Chem 2008, 51:2744-2757.

131. Inoue K, Koizumi S, Fuziwara S, Denda S, Denda M: Functional vanilloid receptors in cultured normal human epidermal keratinocytes. Biochem Biophys Res Commun 2002, 291:124-129.

132. Kim SJ, Lee SA, Yun SJ, Kim JK, Park JS, Jeong HS, Lee JH, Moon SJ, Won YH: Expression of vanilloid receptor 1 in cultured fibroblast. Exp Dermatol 2006, 15:362-367. 
133. Grone A, Fonfara S, Baumgartner W: Cell type-dependent cytokine expression after canine distemper virus infection. Viral Immunol 2002, 15:493-505.

134. Southall MD, Li T, Gharibova LS, Pei Y, Nicol GD, Travers JB: Activation of epidermal vanilloid receptor-1 induces release of proinflammatory mediators in human keratinocytes. $J$ Pharmacol Exp Ther 2003, 304:217-222.

135. Saunders CI, Kunde DA, Crawford A, Geraghty DP: Expression of transient receptor potential vanilloid 1 (TRPV1) and 2 (TRPV2) in human peripheral blood. Mol Immunol 2007, 44:1429-1435.

136. Basu S, Srivastava P: Immunological role of neuronal receptor vanilloid receptor 1 expressed on dendritic cells. Proc Natl Acad Sci U S A 2005, 102:5120-5125.

137. Geppetti P, Nassini R, Materazzi S, Benemei S: The concept of neurogenic inflammation. $B J U$ Int 2008, 101 Suppl 3:2-6.

138. Earley S, Gonzales AL, Crnich R: Endothelium-dependent cerebral artery dilation mediated by TRPA1 and Ca2+-Activated K+ channels. Circ Res 2009, 104:987994.

139. Kark T, Bagi Z, Lizanecz E, Pasztor ET, Erdei N, Czikora A, Papp Z, Edes I, Porszasz $\mathrm{R}$, Toth A: Tissue-specific regulation of microvascular diameter: opposite functional roles of neuronal and smooth muscle located vanilloid receptor-1. $\mathrm{Mol}$ Pharmacol 2008, 73:1405-1412.

140. Luo D, Zhang YW, Peng WJ, Peng J, Chen QQ, Li D, Deng HW, Li YJ: Transient receptor potential vanilloid 1-mediated expression and secretion of endothelial cell-derived calcitonin gene-related peptide. Regul Pept 2008, 150:66-72.

141. Brain SD, Williams TJ, Tippins JR, Morris HR, MacIntyre I: Calcitonin gene-related peptide is a potent vasodilator. Nature 1985, 313:54-56.

142. Zygmunt PM, Petersson J, Andersson DA, Chuang H, Sorgard M, Di Marzo V, Julius D, Hogestatt ED: Vanilloid receptors on sensory nerves mediate the vasodilator action of anandamide. Nature 1999, 400:452-457.

143. Keeble JE, Brain SD: Capsaicin-induced vasoconstriction in the mouse knee joint: a study using TRPV1 knockout mice. Neurosci Lett 2006, 401:55-58.

144. Cavanaugh DJ, Chesler AT, Jackson AC, Sigal YM, Yamanaka H, Grant R, O'Donnell D, Nicoll RA, Shah NM, Julius D, Basbaum AI: Trpv1 reporter mice reveal highly restricted brain distribution and functional expression in arteriolar smooth muscle cells. $J$ Neurosci 2011, 31:5067-5077.

145. Dux M, Santha P, Jancso G: Capsaicin-sensitive neurogenic sensory vasodilatation in the dura mater of the rat. $J$ Physiol 2003, 552:859-867.

146. Wang YX, Wang J, Wang C, Liu J, Shi LP, Xu M: Functional expression of transient receptor potential vanilloid-related channels in chronically hypoxic human pulmonary arterial smooth muscle cells. J Membr Biol 2008, 223:151-159.

147. Hwang JT, Park IJ, Shin JI, Lee YK, Lee SK, Baik HW, Ha J, Park OJ: Genistein, EGCG, and capsaicin inhibit adipocyte differentiation process via activating AMP-activated protein kinase. Biochem Biophys Res Commun 2005, 338:694-699.

148. Hsu CL, Yen GC: Effects of capsaicin on induction of apoptosis and inhibition of adipogenesis in 3T3-L1 cells. J Agric Food Chem 2007, 55:1730-1736.

149. Zhang LL, Yan Liu D, Ma LQ, Luo ZD, Cao TB, Zhong J, Yan ZC, Wang LJ, Zhao $\mathrm{ZG}$, $\mathrm{Zhu} \mathrm{SJ}$, et al: Activation of transient receptor potential vanilloid type-1 channel prevents adipogenesis and obesity. Circ Res 2007, 100:1063-1070. 
150. Ohnuki K, Haramizu S, Oki K, Watanabe T, Yazawa S, Fushiki T: Administration of capsiate, a non-pungent capsaicin analog, promotes energy metabolism and suppresses body fat accumulation in mice. Biosci Biotechnol Biochem 2001, 65:2735-2740.

151. Kang JH, Goto T, Han IS, Kawada T, Kim YM, Yu R: Dietary capsaicin reduces obesity-induced insulin resistance and hepatic steatosis in obese mice fed a highfat diet. Obesity (Silver Spring) 2010, 18:780-787.

152. Romanovsky AA, Almeida MC, Garami A, Steiner AA, Norman MH, Morrison SF, Nakamura K, Burmeister JJ, Nucci TB: The transient receptor potential vanilloid-1 channel in thermoregulation: a thermosensor it is not. Pharmacol Rev 2009, 61:228-261.

153. Caterina MJ: Transient receptor potential ion channels as participants in thermosensation and thermoregulation. Am J Physiol Regul Integr Comp Physiol 2007, 292:R64-76.

154. Masamoto $\mathrm{Y}$, Kawabata $\mathrm{F}$, Fushiki $\mathrm{T}$ : Intragastric administration of TRPV1, TRPV3, TRPM8, and TRPA1 agonists modulates autonomic thermoregulation in different manners in mice. Biosci Biotechnol Biochem 2009, 73:1021-1027.

155. Kawabata F, Inoue N, Masamoto Y, Matsumura S, Kimura W, Kadowaki M, Higashi $\mathrm{T}$, Tominaga $\mathrm{M}$, Inoue $\mathrm{K}$, Fushiki $\mathrm{T}$ : Non-pungent capsaicin analogs (capsinoids) increase metabolic rate and enhance thermogenesis via gastrointestinal TRPV1 in mice. Biosci Biotechnol Biochem 2009, 73:2690-2697.

156. Toth DM, Szoke E, Bolcskei K, Kvell K, Bender B, Bosze Z, Szolcsanyi J, Sandor Z: Nociception, neurogenic inflammation and thermoregulation in TRPV1 knockdown transgenic mice. Cell Mol Life Sci 2011, 68:2589-2601.

157. Bodo E, Biro T, Telek A, Czifra G, Griger Z, Toth BI, Mescalchin A, Ito T, Bettermann A, Kovacs L, Paus R: A hot new twist to hair biology: involvement of vanilloid receptor-1 (VR1/TRPV1) signaling in human hair growth control. $A m J$ Pathol 2005, 166:985-998.

158. White JP, Urban L, Nagy I: TRPV1 function in health and disease. Curr Pharm Biotechnol 2011, 12:130-144.

159. Cortright DN, Krause JE, Broom DC: TRP channels and pain. Biochim Biophys Acta 2007, 1772:978-988.

160. Gunthorpe MJ, Szallasi A: Peripheral TRPV1 receptors as targets for drug development: new molecules and mechanisms. Curr Pharm Des 2008, 14:32-41.

161. Toth A, Boczan J, Kedei N, Lizanecz E, Bagi Z, Papp Z, Edes I, Csiba L, Blumberg PM: Expression and distribution of vanilloid receptor 1 (TRPV1) in the adult rat brain. Brain Res Mol Brain Res 2005, 135:162-168.

162. Yiangou Y, Facer P, Dyer NH, Chan CL, Knowles C, Williams NS, Anand P: Vanilloid receptor 1 immunoreactivity in inflamed human bowel. Lancet 2001, 357:1338-1339.

163. Chan CL, Facer P, Davis JB, Smith GD, Egerton J, Bountra C, Williams NS, Anand P: Sensory fibres expressing capsaicin receptor TRPV1 in patients with rectal hypersensitivity and faecal urgency. Lancet 2003, 361:385-391.

164. Everaerts W, Gees M, Alpizar YA, Farre R, Leten C, Apetrei A, Dewachter I, van Leuven F, Vennekens $\mathrm{R}$, De Ridder $\mathrm{D}$, et al: The capsaicin receptor TRPV1 is a crucial mediator of the noxious effects of mustard oil. Curr Biol 2011, 21:316-321. 
165. Mori N, Kawabata F, Matsumura S, Hosokawa H, Kobayashi S, Inoue K, Fushiki T: Intragastric administration of allyl isothiocyanate increases carbohydrate oxidation via TRPV1 but not TRPA1 in mice. Am J Physiol Regul Integr Comp Physiol 2011, 300:R1494-1505.

166. Ohta $\mathrm{T}$, Imagawa $\mathrm{T}$, Ito $\mathrm{S}$ : Novel agonistic action of mustard oil on recombinant and endogenous porcine transient receptor potential V1 (pTRPV1) channels. Biochem Pharmacol 2007, 73:1646-1656.

167. Bandell M, Story GM, Hwang SW, Viswanath V, Eid SR, Petrus MJ, Earley TJ, Patapoutian A: Noxious cold ion channel TRPA1 is activated by pungent compounds and bradykinin. Neuron 2004, 41:849-857.

168. Story GM, Peier AM, Reeve AJ, Eid SR, Mosbacher J, Hricik TR, Earley TJ, Hergarden AC, Andersson DA, Hwang SW, et al: ANKTM1, a TRP-like channel expressed in nociceptive neurons, is activated by cold temperatures. Cell 2003, 112:819-829.

169. Bautista DM, Movahed P, Hinman A, Axelsson HE, Sterner O, Hogestatt ED, Julius $\mathrm{D}$, Jordt SE, Zygmunt PM: Pungent products from garlic activate the sensory ion channel TRPA1. Proc Natl Acad Sci U S A 2005, 102:12248-12252.

170. Tender GC, Walbridge S, Olah Z, Karai L, Iadarola M, Oldfield EH, Lonser RR: Selective ablation of nociceptive neurons for elimination of hyperalgesia and neurogenic inflammation. $J$ Neurosurg 2005, 102:522-525.

171. Jancso G, Jancso-Gabor A: Effect of capsaicin on morphine analgesia--possible involvement of hypothalamic structures. Naunyn Schmiedebergs Arch Pharmacol 1980, 311:285-288.

172. Enyeart JJ, Xu L, Enyeart JA: Dual actions of lanthanides on ACTH-inhibited leak K(+) channels. Am J Physiol Endocrinol Metab 2002, 282:E1255-1266.

173. Olah Z, Lehel C, Jakab G, Anderson WB: A cloning and epsilon-epitope-tagging insert for the expression of polymerase chain reaction-generated cDNA fragments in Escherichia coli and mammalian cells. Anal Biochem 1994, 221:94102.

174. Pecze L, Szabo K, Szell M, Josvay K, Kaszas K, Kusz E, Letoha T, Prorok J, Koncz I, Toth A, et al: Human keratinocytes are vanilloid resistant. PLoS ONE 2008, 3:e3419.

175. De Petrocellis L, Bisogno T, Maccarrone M, Davis JB, Finazzi-Agro A, Di Marzo V: The activity of anandamide at vanilloid VR1 receptors requires facilitated transport across the cell membrane and is limited by intracellular metabolism. $J$ Biol Chem 2001, 276:12856-12863.

176. Garcia-Martinez C, Morenilla-Palao C, Planells-Cases R, Merino JM, Ferrer-Montiel A: Identification of an aspartic residue in the $P$-loop of the vanilloid receptor that modulates pore properties. $J$ Biol Chem 2000, 275:32552-32558.

177. Olah Z, Josvay K, Pecze L, Letoha T, Babai N, Budai D, Otvos F, Szalma S, Vizler C: Anti-calmodulins and tricyclic adjuvants in pain therapy block the TRPV1 channel. PLoS ONE 2007, 2:e545.

178. Chung MK, Guler AD, Caterina MJ: TRPV1 shows dynamic ionic selectivity during agonist stimulation. Nat Neurosci 2008, 11:555-564.

179. Binshtok AM, Bean BP, Woolf CJ: Inhibition of nociceptors by TRPV1-mediated entry of impermeant sodium channel blockers. Nature 2007, 449:607-610. 
180. Fernihough J, Gentry C, Bevan S, Winter J: Regulation of calcitonin gene-related peptide and TRPV1 in a rat model of osteoarthritis. Neurosci Lett 2005, 388:7580.

181. Ji RR, Samad TA, Jin SX, Schmoll R, Woolf CJ: p38 MAPK activation by NGF in primary sensory neurons after inflammation increases TRPV1 levels and maintains heat hyperalgesia. Neuron 2002, 36:57-68.

182. Malin S, Molliver D, Christianson JA, Schwartz ES, Cornuet P, Albers KM, Davis BM: TRPV1 and TRPA1 function and modulation are target tissue dependent. $J$ Neurosci 2011, 31:10516-10528.

183. Zhang X, Huang J, McNaughton PA: NGF rapidly increases membrane expression of TRPV1 heat-gated ion channels. EMBO J 2005, 24:4211-4223.

184. Pecze L, Pelsoczi P, Kecskes M, Winter Z, Papp A, Kaszas K, Letoha T, Vizler C, Olah Z: Resiniferatoxin mediated ablation of TRPV1+ neurons removes TRPA1 as well. Can J Neurol Sci 2009, 36:234-241.

185. Winter Z, Buhala A, Otvos F, Josvay K, Vizler C, Dombi G, Szakonyi G, Olah Z: Functionally important amino acid residues in the transient receptor potential vanilloid 1 (TRPV1) ion channel -- an overview of the current mutational data. Mol Pain 2013, 9:30.

186. Jin HW, Ichikawa H, Fujita M, Yamaai T, Mukae K, Nomura K, Sugimoto T: Involvement of caspase cascade in capsaicin-induced apoptosis of dorsal root ganglion neurons. Brain Res 2005, 1056:139-144.

187. Brown DC, Iadarola MJ, Perkowski SZ, Erin H, Shofer F, Laszlo KJ, Olah Z, Mannes AJ: Physiologic and antinociceptive effects of intrathecal resiniferatoxin in a canine bone cancer model. Anesthesiology 2005, 103:1052-1059.

188. Tousova K, Susankova K, Teisinger J, Vyklicky L, Vlachova V: Oxidizing reagent copper-o-phenanthroline is an open channel blocker of the vanilloid receptor TRPV1. Neuropharmacology 2004, 47:273-285.

189. Pecze L, Winter Z, Josvay K, Otvos F, Kolozsi C, Vizler C, Budai D, Letoha T, Dombi G, Szakonyi G, Olah Z: Divalent heavy metal cations block the TRPV1 Ca(2+) channel. Biol Trace Elem Res 2013, 151:451-461.

190. Banvolgyi A, Pozsgai G, Brain SD, Helyes ZS, Szolcsanyi J, Ghosh M, Melegh B, Pinter E: Mustard oil induces a transient receptor potential vanilloid 1 receptorindependent neurogenic inflammation and a non-neurogenic cellular inflammatory component in mice. Neuroscience 2004, 125:449-459.

191. Gamse R: Capsaicin and nociception in the rat and mouse. Possible role of substance P. Naunyn Schmiedebergs Arch Pharmacol 1982, 320:205-216.

192. Holzer P, Jurna I, Gamse R, Lembeck F: Nociceptive threshold after neonatal capsaicin treatment. Eur J Pharmacol 1979, 58:511-514.

193. Cervero F, McRitchie HA: Neonatal capsaicin and thermal nociception: a paradox. Brain Res 1981, 215:414-418.

194. Hayes AG, Scadding JW, Skingle M, Tyers MB: Effects of neonatal administration of capsaicin on nociceptive thresholds in the mouse and rat. $J$ Pharm Pharmacol 1981, 33:183-185.

195. Neubert JK, Mannes AJ, Karai LJ, Jenkins AC, Zawatski L, Abu-Asab M, Iadarola MJ: Perineural resiniferatoxin selectively inhibits inflammatory hyperalgesia. Mol Pain 2008, 4:3. 
196. Caterina MJ, Leffler A, Malmberg AB, Martin WJ, Trafton J, Petersen-Zeitz KR, Koltzenburg M, Basbaum AI, Julius D: Impaired nociception and pain sensation in mice lacking the capsaicin receptor. Science 2000, 288:306-313.

197. Davis JB, Gray J, Gunthorpe MJ, Hatcher JP, Davey PT, Overend P, Harries MH, Latcham J, Clapham $\mathrm{C}$, Atkinson $\mathrm{K}$, et al: Vanilloid receptor-1 is essential for inflammatory thermal hyperalgesia. Nature 2000, 405:183-187.

198. Obata K, Katsura H, Mizushima T, Yamanaka H, Kobayashi K, Dai Y, Fukuoka T, Tokunaga A, Tominaga $M$, Noguchi $K$ : TRPA1 induced in sensory neurons contributes to cold hyperalgesia after inflammation and nerve injury. $J$ Clin Invest 2005, 115:2393-2401.

199. Katsura H, Obata K, Mizushima T, Yamanaka H, Kobayashi K, Dai Y, Fukuoka T, Tokunaga A, Sakagami M, Noguchi K: Antisense knock down of TRPA1, but not TRPM8, alleviates cold hyperalgesia after spinal nerve ligation in rats. Exp Neurol 2006, 200:112-123.

200. Reid G, Babes A, Pluteanu F: A cold- and menthol-activated current in rat dorsal root ganglion neurones: properties and role in cold transduction. $J$ Physiol 2002, 545:595-614.

201. Choi Y, Yoon YW, Na HS, Kim SH, Chung JM: Behavioral signs of ongoing pain and cold allodynia in a rat model of neuropathic pain. Pain 1994, 59:369-376.

202. Takahashi K, Sato J, Mizumura K: Responses of C-fiber low threshold mechanoreceptors and nociceptors to cold were facilitated in rats persistently inflamed and hypersensitive to cold. Neurosci Res 2003, 47:409-419.

203. Saade NE, Massaad CA, Ochoa-Chaar CI, Jabbur SJ, Safieh-Garabedian B, Atweh SF: Upregulation of proinflammatory cytokines and nerve growth factor by intraplantar injection of capsaicin in rats. $J$ Physiol 2002, 545:241-253.

204. Frederick J, Buck ME, Matson DJ, Cortright DN: Increased TRPA1, TRPM8, and TRPV2 expression in dorsal root ganglia by nerve injury. Biochem Biophys Res Commun 2007, 358:1058-1064.

205. Lessard N, Pare M, Lepore F, Lassonde M: Early-blind human subjects localize sound sources better than sighted subjects. Nature 1998, 395:278-280.

206. Nilius B, Prenen J, Vennekens R, Hoenderop JG, Bindels RJ, Droogmans G: Pharmacological modulation of monovalent cation currents through the epithelial Ca2+ channel ECaC1. Br J Pharmacol 2001, 134:453-462.

207. Zeng B, Chen GL, Xu SZ: Divalent copper is a potent extracellular blocker for TRPM2 channel. Biochem Biophys Res Commun 2012, 424:279-284.

208. Sajadi SAA: Complex Bilding Behavior of L-Tryptophan and Related Amino Acids, a Comparative Investigation. American Journal of Chemistry 2011, 1:60-64.

209. Irving H, Williams RJP: The stability of transition-metal complexes. Journal of the Chemical Society 1953:3192-3210.

210. Shannon R: Revised effective ionic radii and systematic studies of interatomic distances in halides and chalcogenides. Acta Crystallographica Section A 1976, 32:751-767.

211. Vulcu SD, Liewald JF, Gillen C, Rupp J, Nawrath H: Proton conductance of human transient receptor potential-vanilloid type-1 expressed in oocytes of Xenopus laevis and in Chinese hamster ovary cells. Neuroscience 2004, 125:861-866.

212. Grant ER, Dubin AE, Zhang SP, Zivin RA, Zhong Z: Simultaneous intracellular calcium and sodium flux imaging in human vanilloid receptor 1 (VR1)- 
transfected human embryonic kidney cells: a method to resolve ionic dependence of VR1-mediated cell death. J Pharmacol Exp Ther 2002, 300:9-17.

213. Hu-Tsai M, Winter $\mathrm{J}$, Woolf $\mathrm{CJ}$ : Regional differences in the distribution of capsaicin-sensitive target-identified adult rat dorsal root ganglion neurons. Neurosci Lett 1992, 143:251-254.

214. Winter J, Evison CJ, O'Brien C, Benowitz L, Lindsay RM, Mulderry P, Woolf C: Neurotoxic damage evokes regenerative responses from adult rat sensory neurones. Neurosci Lett 1992, 146:48-52.

215. Reichling DB, Barratt L, Levine JD: Heat-induced cobalt entry: an assay for heat transduction in cultured rat dorsal root ganglion neurons. Neuroscience 1997, 77:291-294.

216. Nishimura T, Krier J, Akasu T: Effects of vasoactive intestinal contractor on voltage-activated $\mathbf{C a 2}+$ currents in feline parasympathetic neurons. Am J Physiol 1993, 265:G1158-1168.

217. Catterall WA, Perez-Reyes E, Snutch TP, Striessnig J: International Union of Pharmacology. XLVIII. Nomenclature and structure-function relationships of voltage-gated calcium channels. Pharmacol Rev 2005, 57:411-425.

218. Guy HR, Conti F: Pursuing the structure and function of voltage-gated channels. Trends Neurosci 1990, 13:201-206.

219. Doughty SW, Blaney FE, Orlek BS, Richards WG: A molecular mechanism for toxin block in N-type calcium channels. Protein Eng 1998, 11:95-99.

220. Mikala G, Bahinski A, Yatani A, Tang S, Schwartz A: Differential contribution by conserved glutamate residues to an ion-selectivity site in the L-type Ca2+ channel pore. FEBS Lett 1993, 335:265-269.

221. Castelli L, Tanzi F, Taglietti V, Magistretti J: Cu2+, Co2+, and Mn2+ modify the gating kinetics of high-voltage-activated $\mathrm{Ca} 2+$ channels in rat palaeocortical neurons. $J$ Membr Biol 2003, 195:121-136.

222. Hagiwara S, Byerly L: Calcium channel. Annu Rev Neurosci 1981, 4:69-125.

223. Thevenod F, Jones SW: Cadmium block of calcium current in frog sympathetic neurons. Biophys $J$ 1992, 63:162-168.

224. Winegar BD, Kelly R, Lansman JB: Block of current through single calcium channels by $\mathrm{Fe}, \mathrm{Co}$, and Ni. Location of the transition metal binding site in the pore. J Gen Physiol 1991, 97:351-367.

225. Gavva NR, Tamir R, Klionsky L, Norman MH, Louis JC, Wild KD, Treanor JJ: Proton activation does not alter antagonist interaction with the capsaicin-binding pocket of TRPV1. Mol Pharmacol 2005, 68:1524-1533.

226. Myers BR, Bohlen CJ, Julius D: A yeast genetic screen reveals a critical role for the pore helix domain in TRP channel gating. Neuron 2008, 58:362-373.

227. Mohapatra DP, Nau C: Desensitization of capsaicin-activated currents in the vanilloid receptor TRPV1 is decreased by the cyclic AMP-dependent protein kinase pathway. $J$ Biol Chem 2003, 278:50080-50090.

228. Mohapatra DP, Wang SY, Wang GK, Nau C: A tyrosine residue in TM6 of the Vanilloid Receptor TRPV1 involved in desensitization and calcium permeability of capsaicin-activated currents. Mol Cell Neurosci 2003, 23:314-324.

229. Latorre R, Zaelzer C, Brauchi S: Structure-functional intimacies of transient receptor potential channels. $Q$ Rev Biophys 2009, 42:201-246. 
230. Kwak J, Wang MH, Hwang SW, Kim TY, Lee SY, Oh U: Intracellular ATP increases capsaicin-activated channel activity by interacting with nucleotidebinding domains. $J$ Neurosci 2000, 20:8298-8304.

231. Grandl J, Kim SE, Uzzell V, Bursulaya B, Petrus M, Bandell M, Patapoutian A: Temperature-induced opening of TRPV1 ion channel is stabilized by the pore domain. Nat Neurosci 2010, 13:708-714.

232. Jordt SE, Julius D: Molecular basis for species-specific sensitivity to "hot" chili peppers. Cell 2002, 108:421-430.

233. Numazaki M, Tominaga M: Nociception and TRP Channels. Curr Drug Targets CNS Neurol Disord 2004, 3:479-485.

234. Numazaki M, Tominaga T, Toyooka H, Tominaga M: Direct phosphorylation of capsaicin receptor VR1 by protein kinase Cepsilon and identification of two target serine residues. $J$ Biol Chem 2002, 277:13375-13378.

235. Ho KW, Ward NJ, Calkins DJ: TRPV1: a stress response protein in the central nervous system. Am J Neurodegener Dis 2012, 1:1-14.

236. Gavva NR, Klionsky L, Qu Y, Shi L, Tamir R, Edenson S, Zhang TJ, Viswanadhan VN, Toth A, Pearce LV, et al: Molecular determinants of vanilloid sensitivity in TRPV1. J Biol Chem 2004, 279:20283-20295.

237. Lee JH, Lee Y, Ryu H, Kang DW, Lee J, Lazar J, Pearce LV, Pavlyukovets VA, Blumberg PM, Choi S: Structural insights into transient receptor potential vanilloid type 1 (TRPV1) from homology modeling, flexible docking, and mutational studies. $J$ Comput Aided Mol Des 2011, 25:317-327.

238. Chou MZ, Mtui T, Gao YD, Kohler M, Middleton RE: Resiniferatoxin binds to the capsaicin receptor (TRPV1) near the extracellular side of the S4 transmembrane domain. Biochemistry 2004, 43:2501-2511.

239. Johnson DM, Garrett EM, Rutter R, Bonnert TP, Gao YD, Middleton RE, Sutton KG: Functional mapping of the transient receptor potential vanilloid 1 intracellular binding site. Mol Pharmacol 2006, 70:1005-1012.

240. Sutton KG, Garrett EM, Rutter AR, Bonnert TP, Jarolimek W, Seabrook GR: Functional characterisation of the S512Y mutant vanilloid human TRPV1 receptor. Br J Pharmacol 2005, 146:702-711.

241. Ryu S, Liu B, Yao J, Fu Q, Qin F: Uncoupling proton activation of vanilloid receptor TRPV1. J Neurosci 2007, 27:12797-12807.

242. Boukalova S, Marsakova L, Teisinger J, Vlachova V: Conserved residues within the putative S4-S5 region serve distinct functions among thermosensitive vanilloid transient receptor potential (TRPV) channels. J Biol Chem 2010, 285:4145541462.

243. Voets $T$, Owsianik G, Janssens A, Talavera $K$, Nilius B: TRPM8 voltage sensor mutants reveal a mechanism for integrating thermal and chemical stimuli. Nat Chem Biol 2007, 3:174-182.

244. Brauchi S, Orta G, Mascayano C, Salazar M, Raddatz N, Urbina H, Rosenmann E, Gonzalez-Nilo F, Latorre R: Dissection of the components for PIP2 activation and thermosensation in TRP channels. Proc Natl Acad Sci U S A 2007, 104:1024610251.

245. Picazo-Juarez G, Romero-Suarez S, Nieto-Posadas A, Llorente I, Jara-Oseguera A, Briggs M, McIntosh TJ, Simon SA, Ladron-de-Guevara E, Islas LD, Rosenbaum T: 
Identification of a binding motif in the S5 helix that confers cholesterol sensitivity to the TRPV1 ion channel. $J$ Biol Chem 2011, 286:24966-24976.

246. Bohlen CJ, Priel A, Zhou S, King D, Siemens J, Julius D: A bivalent tarantula toxin activates the capsaicin receptor, TRPV1, by targeting the outer pore domain. Cell 2010, 141:834-845.

247. Kitaguchi T, Swartz KJ: An inhibitor of TRPV1 channels isolated from funnel Web spider venom. Biochemistry 2005, 44:15544-15549.

248. Welch JM, Simon SA, Reinhart PH: The activation mechanism of rat vanilloid receptor 1 by capsaicin involves the pore domain and differs from the activation by either acid or heat. Proc Natl Acad Sci U S A 2000, 97:13889-13894.

249. Aneiros E, Cao L, Papakosta M, Stevens EB, Phillips S, Grimm C: The biophysical and molecular basis of TRPV1 proton gating. EMBO J 2011, 30:994-1002.

250. Grimm C, Aneiros E, de Groot M: Dissecting TRPV1: lessons to be learned? Channels (Austin) 2011, 5:201-204.

251. Siemens J, Zhou S, Piskorowski R, Nikai T, Lumpkin EA, Basbaum AI, King D, Julius D: Spider toxins activate the capsaicin receptor to produce inflammatory pain. Nature 2006, 444:208-212.

252. Susankova K, Ettrich R, Vyklicky L, Teisinger J, Vlachova V: Contribution of the putative inner-pore region to the gating of the transient receptor potential vanilloid subtype 1 channel (TRPV1). J Neurosci 2007, 27:7578-7585.

253. Salazar H, Jara-Oseguera A, Hernandez-Garcia E, Llorente I, Arias O, II, SorianoGarcia M, Islas LD, Rosenbaum T: Structural determinants of gating in the TRPV1 channel. Nat Struct Mol Biol 2009, 16:704-710.

254. Kuzhikandathil EV, Wang H, Szabo T, Morozova N, Blumberg PM, Oxford GS: Functional analysis of capsaicin receptor (vanilloid receptor subtype 1) multimerization and agonist responsiveness using a dominant negative mutation. J Neurosci 2001, 21:8697-8706.

255. Grycova L, Holendova B, Bumba L, Bily J, Jirku M, Lansky Z, Teisinger J: Integrative binding sites within intracellular termini of TRPV1 receptor. PLoS ONE 2012, 7:e48437.

256. Grycova L, Lansky Z, Friedlova E, Obsilova V, Janouskova H, Obsil T, Teisinger J: Ionic interactions are essential for TRPV1 C-terminus binding to calmodulin. Biochem Biophys Res Commun 2008, 375:680-683. 


\section{Appendix}

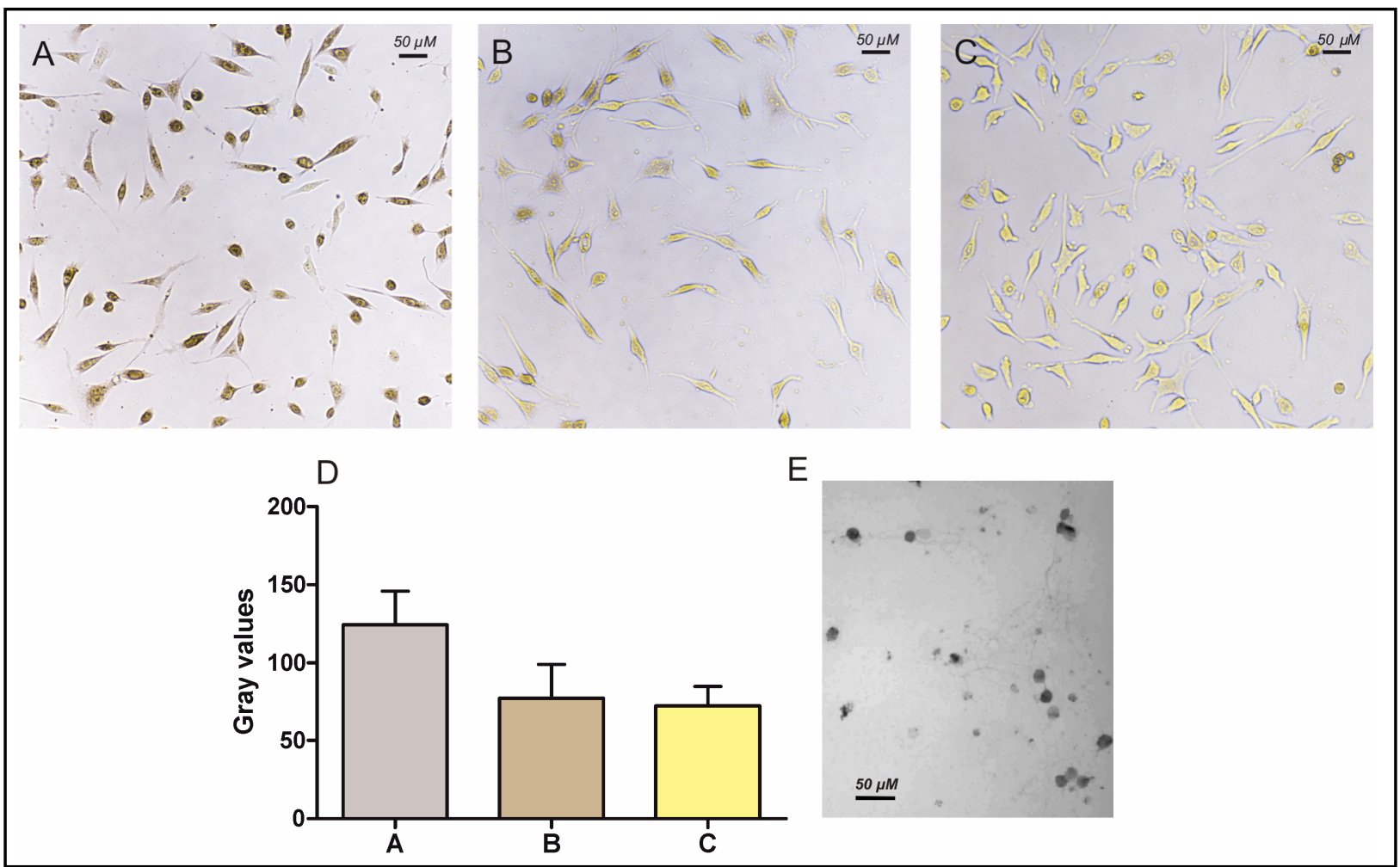

Appendix figure 1: $\mathrm{Co}^{2+}$ histochemistry on the $3 T 3$ cell line expressing TRPV1 ectopically.

Cells were incubated for 10 minutes in buffer A containing $A-20 \mu M C A P S+5 m M \mathrm{Co}^{2+} ; B-20 \mu M C A P S+5$ $\mathrm{mMCO} \mathrm{Co}^{2+}+5 \mu \mathrm{MCapZ}$; $C-5 \mathrm{mMCo} \mathrm{Co}^{2+}$ without CAPS. The dark CoS precipitate indicates the presence of intracellular $\mathrm{Co}^{2+}$ that is blockable with CapZ, a competitive antagonist of pungent vanilloids. D - Gray values of the $3 T 3$ cell line expressing TRPV1 measured by means of ImageJ software. E - Co ${ }^{2+}$ histochemistry in CAPS-sensitive rat DRG neurons. Scale bar $=0.05 \mathrm{~mm}$. These results confirm that $\mathrm{Co}^{2+}$ not only acts as a blocker but also enters the cell with $\mathrm{Ca}^{2+}$ through the TRPVI channel. 


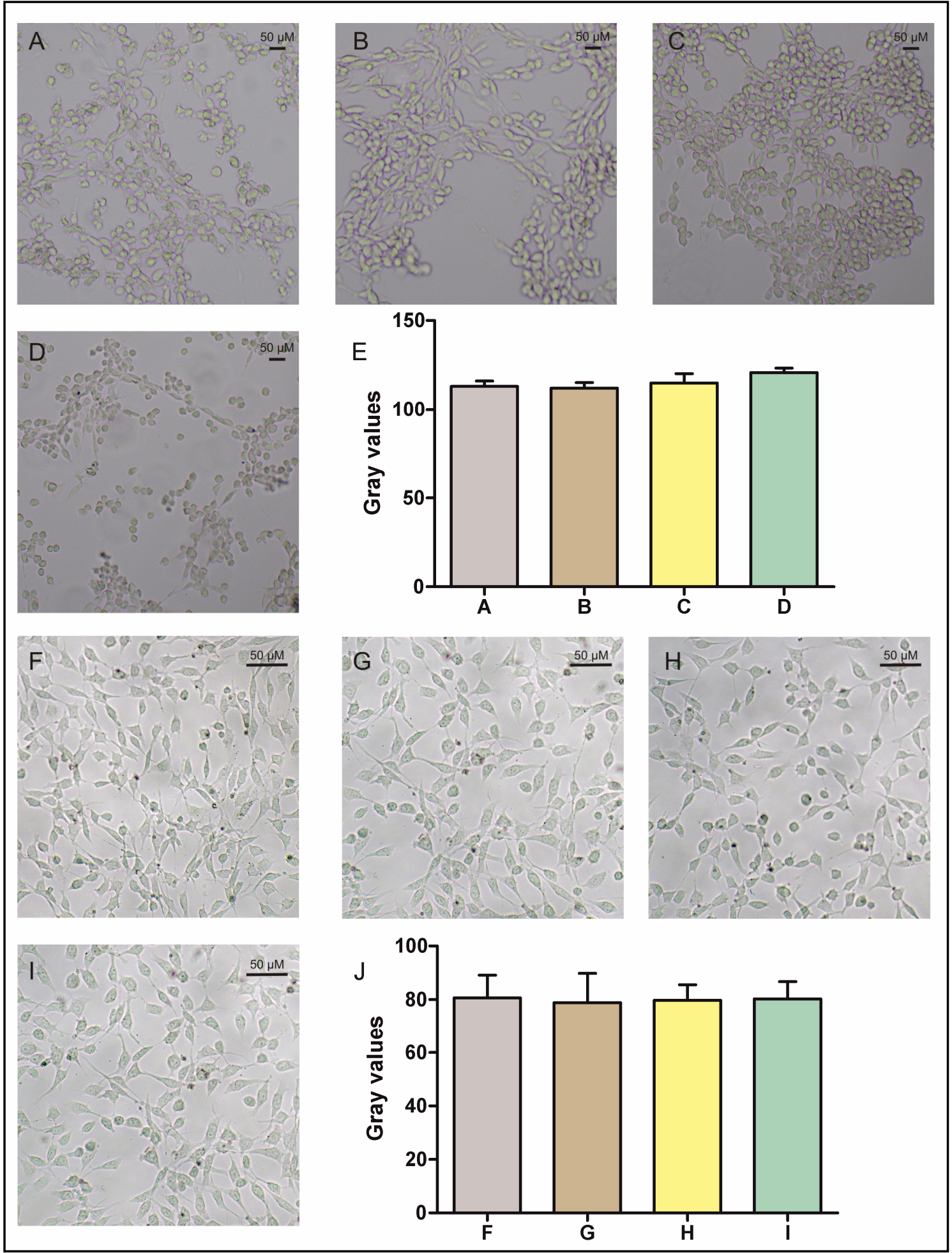

Appendix figure 2: $\mathrm{Co}^{2+}$ histochemistry on the $3 \mathrm{T3}$ cell line.

Cells were incubated for 10 minutes in buffer A containing: $A-20 \mu M C A P S+5 m M \mathrm{Co}^{2+} ; B-20 \mu M$

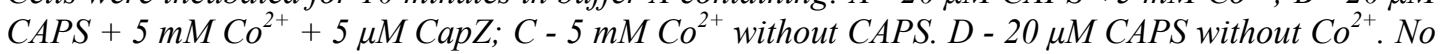
CoS precipitate could be observed in the absence of TRPV1 protein in the cell membrane. E - Gray values of the $3 T 3$ cell line measured by means of ImageJ software. Cells were incubated for 10 min in: $F$ - buffer A containing $5 \mathrm{mM} \mathrm{Co}{ }^{2+} ; \mathrm{G}$ - buffer A without $\mathrm{Co}^{2+} ; \mathrm{H}$ - modified buffer A containing 50 $\mathrm{mM} \mathrm{KCl}+2.5 \mathrm{mM} \mathrm{NaCl}+5 \mathrm{mMCo}^{2+} ; \mathrm{I}$ - modified buffer A containing $50 \mathrm{mM} \mathrm{KCl}+12.5 \mathrm{mM} \mathrm{NaCl}$ without $\mathrm{Co}^{2+} . \mathrm{J}$ - Gray values of the $3 T 3$ cell line measured by means of ImageJ software. These results confirm that $\mathrm{Co}^{2+}$ does not enter the $3 T 3$ cells through VGCCs. 


\section{Appendix table 1: Summary table of the mutated sites of rTRPV1}

\begin{tabular}{|c|c|c|c|}
\hline Residue & Mutated to & $\begin{array}{l}\text { Role in the channel function / Impact of the mutation on the } \\
\text { channel function }\end{array}$ & Refs \\
\hline $\mathrm{C} 73$ & S & $\begin{array}{l}\text { Its mutation caused gain of function and strong toxicity when } \\
\text { expressed in Saccharomyces cerevisiae. }\end{array}$ & [226] \\
\hline $\mathrm{I} 75$ & $\mathrm{~F}$ & $\begin{array}{l}\text { Its mutation caused gain of function mutation and weaker } \\
\text { toxicity when expressed in Saccharomyces cerevisiae. }\end{array}$ & [226] \\
\hline I76 & $\mathrm{T}$ & $\begin{array}{l}\text { Its mutation caused gain of function mutation and weaker } \\
\text { toxicity when expressed in Saccharomyces cerevisiae. }\end{array}$ & [226] \\
\hline V78 & G & $\begin{array}{l}\text { Its mutation caused gain of function mutation and weaker } \\
\text { toxicity when expressed in Saccharomyces cerevisiae. }\end{array}$ & [226] \\
\hline R114 & $\mathrm{A}, \mathrm{E}, \Delta$ & $\begin{array}{l}\text { Its deletion or mutation abrogated vanilloid and proton activation } \\
\text { and RTX binding, without effecting heat activation. }\end{array}$ & [18] \\
\hline R115 & $\mathrm{D}$ & $\begin{array}{l}\text { Its mutation abrogated vanilloid activation and RTX binding, } \\
\text { without effecting heat activation. }\end{array}$ & [18] \\
\hline S116 & A & $\begin{array}{l}\text { The residue is phosphorylated by PKA and is involved in } \\
\text { desensitization. } \\
\text { It is also functional target for PKC } \mu \text {. Its mutation abolished } \\
\text { phosphorylation by PKC } \mu \text { and enhanced the channel response to } \\
\text { CAPS by PKC } \mu \text {. }\end{array}$ & {$[81,86,227,228]$} \\
\hline T144 & & $\begin{array}{l}\text { Its phosphorylation by PKA causes sensitization of heat-evoked } \\
\text { responses. }\end{array}$ & {$[74,79]$} \\
\hline K155 & $\mathrm{A}, \mathrm{E}$ & $\begin{array}{l}\text { Its mutation caused impaired TRPV1-ARD interaction with ATP, } \\
\text { and impaired tachyphylaxis, even in the absence of ATP. The } \\
\text { mutant channel did not interact with CaM, and was slightly more } \\
\text { sensitive to CAPS than the wild type. } \\
\text { Its mutation resulted in a constitutively active channel, and } \\
\text { caused gain of function mutation and weaker toxicity when } \\
\text { expressed in Saccharomyces cerevisiae. }\end{array}$ & {$[16,226]$} \\
\hline $\mathrm{C} 157$ & & $\begin{array}{l}\text { The residue is covalently modified by allicin causing allicin } \\
\text { activation of the channel. }\end{array}$ & [229] \\
\hline K160 & $\mathrm{A}, \mathrm{E}$ & $\begin{array}{l}\text { Its mutation caused impaired TRPV1-ARD interaction with ATP, } \\
\text { and impaired tachyphylaxis, even in the absence of ATP. The } \\
\text { mutant channel did not interact with CaM, and was slightly more } \\
\text { sensitive to CAPS than the wild type. } \\
\text { Its mutation resulted in a constitutively active channel, caused } \\
\text { gain of function mutation and strong toxicity when expressed in } \\
\text { Saccharomyces cerevisiae. }\end{array}$ & {$[16,226]$} \\
\hline H166 & $\mathrm{R}$ & $\begin{array}{l}\text { Its mutation caused gain of function mutation and weaker } \\
\text { toxicity when expressed in Saccharomyces cerevisiae. Its } \\
\text { mutation resulted in significant response to } \mathrm{pH} 6.4 \text { (threshold } \\
\text { concentration for proton-activation). }\end{array}$ & [226] \\
\hline D178 & $\mathrm{N}$ & $\begin{array}{l}\text { Its mutation abolished the ATP-mediated upregulation of } \\
\text { TRPV1. }\end{array}$ & [230] \\
\hline
\end{tabular}




\begin{tabular}{|c|c|c|c|}
\hline Residue & Mutated to & $\begin{array}{l}\text { Role in the channel function / Impact of the mutation on the } \\
\text { channel function }\end{array}$ & Refs \\
\hline Y199 & $\mathrm{A}, \mathrm{F}$ & $\begin{array}{l}\text { When both sites were mutated, Y199/Q202 impaired the TRPV1- } \\
\text { ARD interaction with ATP and ATP-mediated tachyphylaxis. } \\
\text { The mutated channel was slightly more sensitive to CAPS than } \\
\text { the wild type. Mutant channels formed a weaker complex with } \\
\text { CaM than wild type but it still had a 1:1 stoichiometric ratio. } \\
\text { Phosphorylation of hTRPV1 Y200 (Y199 in rTRPV1) by Src } \\
\text { kinase increases the surface expression of TRPV1 and accounts } \\
\text { for rapid sensitizing actions of NGF. When mutated, Src- } \\
\text { dependent, NGF-induced Tyr phosphorylation was completely } \\
\text { abolished. }\end{array}$ & {$[16,183]$} \\
\hline Q202 & A & $\begin{array}{l}\text { When both sites were mutated, Y199/Q202 impaired the TRPV1- } \\
\text { ARD interaction with ATP and ATP-mediated tachyphylaxis. } \\
\text { The mutated channel was slightly more sensitive to CAPS than } \\
\text { the wild type. Mutant channels formed a weaker complex with } \\
\text { CaM than wild type but it still had a 1:1 stoichiometric ratio. }\end{array}$ & {$[16]$} \\
\hline N310 & $\mathrm{D}$ & $\begin{array}{l}\text { Its mutation caused gain of function and weaker toxicity when } \\
\text { expressed in Saccharomyces cerevisiae. }\end{array}$ & [226] \\
\hline S343 & $\mathrm{G}, \mathrm{R}$, & $\begin{array}{l}\text { Its mutation caused gain of function and strong/weak toxicity } \\
\text { when expressed in Saccharomyces cerevisiae. }\end{array}$ & [226] \\
\hline A350 & $\mathrm{T}$ & $\begin{array}{l}\text { Its mutation caused gain of function and strong toxicity when } \\
\text { expressed in Saccharomyces cerevisiae. }\end{array}$ & [226] \\
\hline I352 & $\mathrm{N}, \mathrm{T}$ & $\begin{array}{l}\text { Its mutation caused gain of function mutation and weaker } \\
\text { toxicity when expressed in Saccharomyces cerevisiae. Its } \\
\text { mutation also caused significant response to } \mathrm{pH} 6.4 \text { (threshold } \\
\text { concentration for proton-activation). }\end{array}$ & [226] \\
\hline $\mathrm{T} 370$ & & $\begin{array}{l}\text { The residue is phosphorylated by PKA. It is involved in } \\
\text { desensitization of the channel, and in the sensitization of heat- } \\
\text { evoked TRPV1 responses when phosphorylated by PKA. }\end{array}$ & $\begin{array}{l}{[74,79,81,227,} \\
228]\end{array}$ \\
\hline F489 & $\mathrm{Y}$ & $\begin{array}{l}\text { Mutation resulted in a rightward shift of the CAPS concentration } \\
\text { of half-maximal activation. }\end{array}$ & [231] \\
\hline R491 & $\mathrm{E}, \mathrm{G}$, & Mutation caused reduction in CAPS sensitivity. & {$[232]$} \\
\hline S502 & A & $\begin{array}{l}\text { Its phosphorylation by PKC potentiates CAPS, proton, and } \\
\text { thermal responses, and that by PKA sensitizes the heat-evoked } \\
\text { responses. } \\
\text { It is a CaMKII phosphorylation site. } \\
\text { When associated with T704I, S502A was found to lose the } \\
\text { ability to be activated by CAPS and to lose the ability of } \\
\text { vanilloid binding. } \\
\text { Its mutation reduced PMA enhancement of CAPS-evoked } \\
\text { currents, but had no effect on direct activation by PMA. }\end{array}$ & $\begin{array}{l}{[74,79,81,87} \\
\quad 233,234]\end{array}$ \\
\hline Y511 & $\mathrm{A}, \mathrm{C}, \mathrm{F}$, & $\begin{array}{l}\text { Its mutation abolished CAPS responses, and RTX binding yet } \\
\text { leave activation by heat and protons intact. }\end{array}$ & {$[232,235-238]$} \\
\hline S512 & $\mathrm{A}, \mathrm{F}, \mathrm{T}, \mathrm{Y}$ & $\begin{array}{l}\text { Its mutation abolished CAPS responses and RTX binding, yet } \\
\text { left activation by heat and protons intact. It is involved in I-RTX } \\
\text { binding. }\end{array}$ & $\begin{array}{l}{[232,235,239,} \\
240]\end{array}$ \\
\hline Q519 & $\mathrm{N}$ & Its mutation ablated the vanilloid sensitivity. & {$[232]$} \\
\hline F522 & $\mathrm{L}$ & Its mutation ablated the vanilloid sensitivity. & [232] \\
\hline M523 & $\mathrm{L}$ & Its mutation ablated the vanilloid sensitivity. & [232] \\
\hline S532 & $\mathrm{C}$ & Its mutation ablated the vanilloid sensitivity. & [232] \\
\hline K535 & $\mathrm{E}$ & $\begin{array}{l}\text { Its mutation ablated the vanilloid sensitivity, and affected proton } \\
\text { responses. }\end{array}$ & {$[232,241]$} \\
\hline E536 & $\mathrm{L}, \mathrm{W}$ & $\begin{array}{l}\text { Its mutation ablated the vanilloid sensitivity, and affected proton } \\
\text { responses. }\end{array}$ & {$[232,241]$} \\
\hline
\end{tabular}




\begin{tabular}{|c|c|c|c|}
\hline Residue & Mutated to & $\begin{array}{l}\text { Role in the channel function / Impact of the mutation on the } \\
\text { channel function }\end{array}$ & Refs \\
\hline V538 & A, G, I, L, T & $\begin{array}{l}\text { Its mutation ablated proton activation, but not the proton } \\
\text { potentiation. }\end{array}$ & [241] \\
\hline A539 & $\mathrm{P}$ & Its mutation affected proton responses. & [241] \\
\hline M547 & A, I, L, Q & $\begin{array}{l}\text { The residue is involved in RTX binding, CAPS sensitivity, I- } \\
\text { RTX sensitivity and proton sensitivity. }\end{array}$ & {$[232,236-239]$} \\
\hline W549 & & It is involved in vanilloid binding. & {$[3,236]$} \\
\hline T550 & $\begin{array}{l}\mathrm{A}, \mathrm{C}, \mathrm{I}, \mathrm{S} \\
\quad \mathrm{Y}, \Delta\end{array}$ & $\begin{array}{l}\text { It is an important molecular determinant in vanilloid sensitivity. } \\
\text { Participates in Caps and RTX binding. } \\
\text { Its deletion reduced CAPS sensitivity of the channel. }\end{array}$ & {$[232,236-238]$} \\
\hline R557 & $\mathrm{A}, \mathrm{E}, \mathrm{K}, \mathrm{L}$ & $\begin{array}{l}\text { It is involved in CAPS potentiation of heat-induced currents and } \\
\text { in the transduction of the CAPS-binding signal to the opening of } \\
\text { the pore. } \\
\text { It is also important in deactivation gating process, 2-APB } \\
\text { activation and for voltage-dependent gating. } \\
\text { It contributes to the voltage modulation of the CAPS-induced } \\
\text { currents and the CAPS potentiation of the heat-induced currents. }\end{array}$ & [242] \\
\hline Q560 & $\mathrm{H}, \mathrm{R}$ & $\begin{array}{l}\text { It is involved in the transduction of the CAPS-binding signal to } \\
\text { the opening of the pore. } \\
\text { It is also important in deactivation gating process and for 2-APB } \\
\text { activation. } \\
\text { Its mutation caused significant response to } \mathrm{pH} 6.4 \text { (threshold } \\
\text { concentration for proton-activation). } \\
\text { Its mutation caused gain of function of the channel and weaker } \\
\text { toxicity when expressed in Saccharomyces cerevisiae. }\end{array}$ & {$[226,242]$} \\
\hline Q561 & $\mathrm{H}, \mathrm{R}$ & $\begin{array}{l}\text { Its mutation caused gain of function of the channel and strong } \\
\text { toxicity when expressed in Saccharomyces cerevisiae. }\end{array}$ & [226] \\
\hline M562 & $\mathrm{D}$ & $\begin{array}{l}\text { Its mutation caused significant response to } \mathrm{pH} 6.4 \text { (threshold } \\
\text { concentration for proton-activation). }\end{array}$ & [226] \\
\hline G563 & $\mathrm{S}$ & The residue is involved in the voltage gating of the channel. & [242] \\
\hline E570 & $\mathrm{A}, \mathrm{L}, \mathrm{Q}, \mathrm{R}$ & $\begin{array}{l}\text { The residue contributes to the voltage modulation of the CAPS- } \\
\text { induced currents and the CAPS potentiation of the heat-induced } \\
\text { currents. } \\
\text { It is involved in the transduction of the CAPS-binding signal to } \\
\text { the opening of the pore and in the 2-APB activation of the } \\
\text { channel. } \\
\text { It is also a relevant heat-sensing factor. }\end{array}$ & [242] \\
\hline K571 & $\mathrm{E}$ & $\begin{array}{l}\text { The residue is a specific binding site for 2-APB. } \\
\text { It is involved in voltage sensing and in TRPV1-lipid interactions. }\end{array}$ & {$[3,242-244]$} \\
\hline R575 & A & $\begin{array}{l}\text { The residue is involved in voltage sensing and in TRPV1-lipid } \\
\text { interactions. }\end{array}$ & {$[3,243,244]$} \\
\hline D576 & $\mathrm{N}, \mathrm{R}$ & $\begin{array}{l}\text { The residue is involved in the voltage-dependent gating of } \\
\text { TRPV1, and contributes to the voltage modulation of the CAPS- } \\
\text { induced currents and the CAPS potentiation of the heat-induced } \\
\text { currents. } \\
\text { It contributes to the transduction of the CAPS-binding signal to } \\
\text { the opening of the pore. }\end{array}$ & [242] \\
\hline R579 & $\mathrm{A}, \mathrm{D}, \mathrm{E}$ & $\begin{array}{l}\text { The residue contributes to the voltage modulation of the CAPS- } \\
\text { induced currents and to the CAPS potentiation of heat-induced } \\
\text { currents. It is involved in the voltage sensing and in TRPV1-lipid } \\
\text { interactions. Its mutation decreased the cholesterol response of } \\
\text { the channel. }\end{array}$ & {$[3,242-245]$} \\
\hline
\end{tabular}




\begin{tabular}{|c|c|c|c|}
\hline Residue & Mutated to & $\begin{array}{l}\text { Role in the channel function / Impact of the mutation on the } \\
\text { channel function }\end{array}$ & Refs \\
\hline M581 & $\mathrm{T}$ & $\begin{array}{l}\text { The residue contributes to the transduction of the CAPS-binding } \\
\text { signal to the opening of the pore, and to the deactivation gating } \\
\text { process. It is involved in voltage gating. } \\
\text { Its mutation caused gain of function of the channel and strong } \\
\text { toxicity when expressed in Saccharomyces cerevisiae. }\end{array}$ & {$[226,242]$} \\
\hline F582 & $\mathrm{Q}$ & Its mutation decreased the cholesterol response of the channel. & [245] \\
\hline L585 & I & Its mutation abolished the cholesterol response of the channel. & [245] \\
\hline I599 & A & Its mutation caused reduced DkTx responses. & [246] \\
\hline E600 & $\begin{array}{l}\text { A, D, H, K, } \\
\quad \text { Q, S, V }\end{array}$ & $\begin{array}{l}\text { The residue is involved in the proton potentiation, but not in } \\
\text { proton activation. } \\
\text { Its mutation to neutral or positive residues potentiates responses } \\
\text { to CAPS or heat, and introduction of a residue with lower pKa } \\
\text { decreased the channel sensitivity to CAPS or heat. }\end{array}$ & {$[45,231]$} \\
\hline D601 & $\mathrm{N}$ & $\begin{array}{l}\text { Its mutation reduced the proton-activated currents significantly, } \\
\text { without altering the heat- or CAPS-evoked responses, and } \\
\text { without eliminating the ability of protons to potentiate the } \\
\text { responses to these stimuli. }\end{array}$ & [45] \\
\hline M609 & $\mathrm{T}, \mathrm{V}$ & $\begin{array}{l}\text { Its mutation caused gain of function of the channel and } \\
\text { strong/weak toxicity when expressed in Saccharomyces } \\
\text { cerevisiae. }\end{array}$ & [226] \\
\hline C616 & $\mathrm{G}$ & The residue is involved in DTT interaction. & {$[74,106,188]$} \\
\hline C621 & G & $\begin{array}{l}\text { The residue is responsible for the extracellular modulation of } \\
\text { TRPV1 by reducing agents. It is involved in DTT interaction. Its } \\
\text { mutation and when associated with C616G and C634G } \\
\text { significantly reduced DDT potentiation without having any effect } \\
\text { on the CAPS, heat or voltage gating of the channel. }\end{array}$ & {$[74,106,188]$} \\
\hline N625 & $\mathrm{D}$ & $\begin{array}{l}\text { Its mutation caused toxicity when expressed in Saccharomyces } \\
\text { cerevisiae. }\end{array}$ & [226] \\
\hline Y627 & $\mathrm{A}, \mathrm{W}$ & $\begin{array}{l}\text { The residue contributes to, but do not play a pivotal role in the } \\
\text { proton activation. Its mutation enhanced the sensitivity to the } \\
\text { acylpolyamine toxins AG489 and AG505. }\end{array}$ & {$[241,247]$} \\
\hline N628 & $\mathrm{D}, \mathrm{K}, \mathrm{R}, \mathrm{W}$ & $\begin{array}{l}\text { The residue plays essential roles in the heat response without } \\
\text { affecting the CAPS responses or the desensitization of the } \\
\text { channel. It is involved in proton-induced potentiation. } \\
\text { Its mutation reduced the heat responses in amplitude and shifted } \\
\text { them to higher temperatures, dramatically decreased the } \\
\text { sensitivity to the acylpolyamine toxins AG } 489 \text { and AG } 505 \text { and } \\
\text { caused toxicity when expressed in Saccharomyces cerevisiae. }\end{array}$ & $\begin{array}{l}{[189,226,231} \\
241,247]\end{array}$ \\
\hline S629 & A & $\begin{array}{l}\text { The residue contributes to, but do not play a pivotal role in the } \\
\text { proton activation. }\end{array}$ & [241] \\
\hline T633 & $\mathrm{A}, \mathrm{S}, \mathrm{V}$ & $\begin{array}{l}\text { Its mutation eliminated the proton-activated currents while } \\
\text { leaving normal responses to CAPS and low pH potentiation. } \\
\text { Its mutation exhibited a weaker response to heat in amplitude, } \\
\text { however, the thermal activation threshold was unchanged. }\end{array}$ & [241] \\
\hline C634 & $\mathrm{G}, \mathrm{S}, \mathrm{W}$ & $\begin{array}{l}\text { It is involved in DTT interaction, its mutation and when } \\
\text { associated with C616G and C621G significantly reduced DDT } \\
\text { potentiation without having any effect on the CAPS, heat or } \\
\text { voltage gating of the channel. } \\
\text { Its mutation also enhanced the sensitivity to the acylpolyamine } \\
\text { toxins AG } 489 \text { and AG505, and caused toxicity when expressed } \\
\text { in Saccharomyces cerevisiae. }\end{array}$ & $\begin{array}{l}{[74,106,188,} \\
226,247]\end{array}$ \\
\hline
\end{tabular}




\begin{tabular}{|c|c|c|c|}
\hline Residue & Mutated to & $\begin{array}{l}\text { Role in the channel function / Impact of the mutation on the } \\
\text { channel function }\end{array}$ & Refs \\
\hline E636 & $\mathrm{Q}, \mathrm{W}$ & $\begin{array}{l}\text { The residue is a specific contributor to the CAPS response } \\
\text { without affecting the proton or thermal sensitivity. } \\
\text { Its mutation dramatically decreased the sensitivity to the } \\
\text { acylpolyamine toxins AG489 and AG505. }\end{array}$ & {$[45,247,248]$} \\
\hline F638 & W & $\begin{array}{l}\text { Its mutation enhanced the sensitivity to the acylpolyamine toxins } \\
\text { AG489 and AG505. }\end{array}$ & [247] \\
\hline F640 & $\begin{array}{l}\text { A, C, D, E, } \\
\text { G, H, I, K, } \\
\text { L, M, N, P, } \\
\text { Q, R, S, T, } \\
\text { V, W, Y, }\end{array}$ & $\begin{array}{l}\text { The residue is critical for heat activation. } \\
\text { Its mutation was constitutively active, and caused strong toxicity } \\
\text { when expressed in Saccharomyces cerevisiae. } \\
\text { Its mutation also enhanced the sensitivity to heat and CAPS, and } \\
\text { abolished the proton potentiation of the channel. This mutation } \\
\text { affected gating rather than permeation properties of the channel. }\end{array}$ & [226] \\
\hline T641 & $\mathrm{S}$ & $\begin{array}{l}\text { The residue is involved in acid activation and potentiation. } \\
\text { Its mutant displayed large constitutive channel activation and } \\
\text { caused toxicity when expressed in Saccharomyces cerevisiae. }\end{array}$ & [226] \\
\hline D646 & $\mathrm{N}, \mathrm{W}$ & $\begin{array}{l}\text { The residue is a specific contributor to the CAPS response } \\
\text { without affecting the proton or thermal sensitivity, and it is } \\
\text { engaged in inhibition by RuRed. } \\
\text { Its mutation reduced the permeability of divalent cations and } \\
\text { dramatically decreased the sensitivity to the acylpolyamine } \\
\text { toxins AG489 and AG505. }\end{array}$ & $\begin{array}{l}{[45,176,189,} \\
228,248]\end{array}$ \\
\hline L647 & W & $\begin{array}{l}\text { Its mutation enhanced the sensitivity to the acylpolyamine toxins } \\
\text { AG489 and AG505. }\end{array}$ & [247] \\
\hline E648 & $\mathrm{A}, \mathrm{Q}$ & $\begin{array}{l}\text { The residue is a specific contributor to the CAPS response } \\
\text { without affecting the proton or thermal sensitivity. } \\
\downarrow \\
\text { Its mutation reduced the proton-activated currents significantly, } \\
\text { without altering the heat- or CAPS-evoked responses, and } \\
\text { without eliminating the ability of protons to potentiate the } \\
\text { responses to these stimuli. }\end{array}$ & {$[45,248]$} \\
\hline F649 & $\mathrm{A}, \mathrm{W}$ & $\begin{array}{l}\text { Its mutation caused reduced DkTx responses, and enhanced the } \\
\text { sensitivity to the acylpolyamine toxins AG489 and AG505. }\end{array}$ & {$[246,247]$} \\
\hline $\mathrm{T} 650$ & S & $\begin{array}{l}\text { The residue is involved in proton-induced potentiation. } \\
\text { Its mutation caused large constitutive channel activation with } \\
\text { abolished pH sensitivity. } \\
\text { Its mutation caused toxicity when expressed in Saccharomyces } \\
\text { cerevisiae. }\end{array}$ & [226] \\
\hline E651 & $\mathrm{Q}, \mathrm{W}$ & $\begin{array}{l}\text { The residue is important in } \mathrm{pH} \text { activation. } \\
\text { Its mutation dramatically decreased the sensitivity to the } \\
\text { acylpolyamine toxins AG489 and AG505. }\end{array}$ & $\begin{array}{l}{[45,189,241,} \\
247]\end{array}$ \\
\hline N652 & $\mathrm{D}, \mathrm{T}$ & $\begin{array}{l}\text { The residue plays essential roles in the heat response without } \\
\text { affecting the CAPS responses or the desensitization of the } \\
\text { channel. Its mutation reduced the heat responses in amplitude } \\
\text { and shifted them to higher temperatures. } \\
\text { Its mutation also caused gain of function and strong toxicity } \\
\text { when expressed in Saccharomyces cerevisiae. }\end{array}$ & {$[226,231]$} \\
\hline Y653 & $\mathrm{T}$ & $\begin{array}{l}\text { The residue plays essential roles in the heat response without } \\
\text { affecting the CAPS responses or the desensitization of the } \\
\text { channel. Its mutation reduced the heat responses in amplitude } \\
\text { and shifted them to higher temperatures. }\end{array}$ & [231] \\
\hline K656 & $\mathrm{E}, \mathrm{Q}$ & $\begin{array}{l}\text { Its mutation caused toxicity when expressed in Saccharomyces } \\
\text { cerevisiae. }\end{array}$ & [226] \\
\hline
\end{tabular}




\begin{tabular}{|c|c|c|c|}
\hline Residue & Mutated to & $\begin{array}{l}\text { Role in the channel function / Impact of the mutation on the } \\
\text { channel function }\end{array}$ & Refs \\
\hline A657 & $\mathrm{P}, \mathrm{W}$ & $\begin{array}{l}\text { The residue is critical for DkTx binding, its mutation showed } \\
\text { loss of DkTx sensitivity. }\end{array}$ & [246] \\
\hline V658 & A & $\begin{array}{l}\text { The residue is involved in acid potentiation. } \\
\text { Its mutation showed a potentiation effect under moderately acidic } \\
\text { conditions. } \\
\text { Its mutation also caused toxicity when expressed in } \\
\text { Saccharomyces cerevisiae. }\end{array}$ & [226] \\
\hline F659 & $\begin{array}{l}\text { A, C, E, H, } \\
\text { I, K, L, S, T, } \\
\text { V, W, Y }\end{array}$ & $\begin{array}{l}\text { The residue is involved in proton activation, and is a key } \\
\text { integrator of voltage sensing, proton activation and potentiation. } \\
\text { Its mutation caused lack of both voltage-dependent proton } \\
\text { activation and potentiation, whereas activation by heat or CAPS } \\
\text { was preserved. } \\
\text { Its mutation caused reduced DkTx responses and caused toxicity } \\
\text { when expressed in Saccharomyces cerevisiae. }\end{array}$ & $\begin{array}{l}{[226,246,249-} \\
251]\end{array}$ \\
\hline Y666 & A & Its mutation resulted in non-functional channel. & [252] \\
\hline I668 & A & $\begin{array}{l}\text { Its mutation reduced CAPS sensitivity, heat-induced current } \\
\text { responses and heat-potentiated CAPS currents. }\end{array}$ & [252] \\
\hline L669 & A & $\begin{array}{l}\text { The residue is involved in heat activation but not in CAPS } \\
\text { activation, nor in the heat potentiation of the CAPS currents. }\end{array}$ & [252] \\
\hline Y671 & A & $\begin{array}{l}\text { The residue might contribute to allosteric coupling between } \\
\text { temperature- and CAPS- dependent activation mechanisms. } \\
\text { Its mutation affected the heat-induced current responses, lowered } \\
\text { the CAPS } \mathrm{EC}_{50} \text { value of the channel. Responses to CAPS were } \\
\text { not potentiated by heat in the mutant containing channel, in fact } \\
\text { CAPS-evoked responses were inhibited by heat. } \\
\text { The residue is involved in the regulation of permeability of } \\
\text { divalent cations, it gates the access of smaller cations. }\end{array}$ & $\begin{array}{l}{[176,228,235} \\
\quad 252,253]\end{array}$ \\
\hline I672 & A & $\begin{array}{l}\text { Its mutation reduced CAPS sensitivity, heat-induced current } \\
\text { responses and heat-potentiated CAPS currents. }\end{array}$ & [252] \\
\hline L673 & $\mathrm{A}, \mathrm{I}$ & $\begin{array}{l}\text { Its mutation caused gain of function and strong toxicity when } \\
\text { expressed in Saccharomyces cerevisiae. } \\
\text { Its mutation also reduced CAPS sensitivity, heat-induced current } \\
\text { responses and heat-potentiated CAPS currents. }\end{array}$ & {$[226,252]$} \\
\hline L674 & A & $\begin{array}{l}\text { Its mutation reduced CAPS sensitivity, heat-induced current } \\
\text { responses and heat-potentiated CAPS currents. }\end{array}$ & [252] \\
\hline L675 & A & $\begin{array}{l}\text { Its mutation reduced CAPS sensitivity and heat-potentiated } \\
\text { CAPS currents. }\end{array}$ & [252] \\
\hline N676 & $\mathrm{A}, \mathrm{F}$ & $\begin{array}{l}\text { Its mutation influenced the ability of CAPS and RTX to activate } \\
\text { TRPV1 without changing the response of the channel to protons. } \\
\text { Its mutation to Ala resulted in non-functional channel. }\end{array}$ & {$[252,254]$} \\
\hline M677 & $\mathrm{A}$ & $\begin{array}{l}\text { Its mutation in a triple mutant }(\mathrm{N} 676 \mathrm{~F} / \mathrm{M} 677 \mathrm{~A} / \mathrm{L} 678 \mathrm{P}) \\
\text { influenced the ability of CAPS and RTX to activate TRPV1 } \\
\text { without changing the response of the channel to protons. } \\
\text { Its mutation alone blunted heat-induced current responses } \\
\text { without a significant change of CAPS- or heat-potentiated CAPS } \\
\text { currents. }\end{array}$ & {$[252,254]$} \\
\hline L678 & $\mathrm{A}, \mathrm{P}$ & $\begin{array}{l}\text { Its mutation influenced the ability of CAPS and RTX to activate } \\
\text { TRPV1 without changing the response of the channel to protons. } \\
\text { Its mutation also blunted heat-induced current responses, with a } \\
\text { leftward shift in the temperature threshold. }\end{array}$ & {$[252,254]$} \\
\hline I679 & A & $\begin{array}{l}\text { Its mutation retained normal sensitivities to CAPS and heat, } \\
\text { although it completely removed their mutual potentiation. }\end{array}$ & [252] \\
\hline
\end{tabular}




\begin{tabular}{|c|c|c|c|}
\hline Residue & Mutated to & $\begin{array}{l}\text { Role in the channel function / Impact of the mutation on the } \\
\text { channel function }\end{array}$ & Refs \\
\hline L681 & A & $\begin{array}{l}\text { The residue is involved in the regulation of permeability of } \\
\text { divalent cations, it regulates the permeability of large cations. }\end{array}$ & {$[235,252,253]$} \\
\hline M682 & A & $\begin{array}{l}\text { Its mutation caused impaired CAPS- and heat- activation, and } \\
\text { significantly reduced their mutual potentiation. }\end{array}$ & [252] \\
\hline E684 & $\mathrm{G}, \mathrm{V}$ & $\begin{array}{l}\text { Its mutation caused gain of function and strong toxicity when } \\
\text { expressed in Saccharomyces cerevisiae. } \\
\text { Its mutation caused significant response to } \mathrm{pH} 6.4 \text { (threshold } \\
\text { concentration for proton-activation). }\end{array}$ & [226] \\
\hline I689 & $\mathrm{V}$ & $\begin{array}{l}\text { Its mutation caused gain of function mutation and weaker } \\
\text { toxicity when expressed in Saccharomyces cerevisiae. }\end{array}$ & [226] \\
\hline K694 & A & The residue participates in PIP2 binding. & {$[255]$} \\
\hline K698 & A & The residue participates in PIP2 binding. & [255] \\
\hline Q700 & A & The residue participates in PIP2 binding. & [255] \\
\hline R701 & A & The residue participates in PIP2 binding. & {$[244,255]$} \\
\hline $\mathrm{T} 704$ & I & $\begin{array}{l}\text { The residue is a CaMKII phosphorylation site. } \\
\text { PMA decreases the binding of }{ }^{3} \mathrm{H}-\mathrm{RTX} \text { to TRPV1 through } \\
\text { interaction with this residue. } \\
\text { When associated with S502A, its mutation lost the ability to be } \\
\text { activated by CAPS and lost the ability of vanilloid binding. }\end{array}$ & $\begin{array}{l}{[48,81,87,109,} \\
234]\end{array}$ \\
\hline K710 & $A, R$ & $\begin{array}{l}\text { The residue participates in PIP } 2 \text { binding. } \\
\text { Its mutation caused gain of function and strong toxicity when } \\
\text { expressed in Saccharomyces cerevisiae. }\end{array}$ & {$[226,244,255]$} \\
\hline Q727 & & The residue has key roles in heat activation. & [244] \\
\hline F742 & $\mathrm{S}$ & $\begin{array}{l}\text { Its mutation caused gain of function and strong toxicity when } \\
\text { expressed in Saccharomyces cerevisiae. }\end{array}$ & [226] \\
\hline W752 & & The residue has key roles in heat activation. & {$[244]$} \\
\hline E761 & $\mathrm{K}, \mathrm{Q}, \Delta$ & $\begin{array}{l}\text { Its deletion or mutation blocks RTX binding and proton- and } \\
\text { CAPS-induced currents without affecting TRPV1 activation by } \\
\text { heat. }\end{array}$ & {$[18,228,252]$} \\
\hline K770 & A & The residue participates in PIP2 binding. & {$[255]$} \\
\hline R771 & A & The residue participates in PIP2 binding. & [255] \\
\hline R778 & A & The residue has key roles in PIP2 binding. & {$[255,256]$} \\
\hline $\mathrm{R} 781$ & A & The residue has key roles in PIP2 binding. & {$[255,256]$} \\
\hline R785 & A & The residue participates in PIP2 binding. & {$[255,256]$} \\
\hline W787 & $\mathrm{R}$ & $\begin{array}{l}\text { Its mutation caused gain of function and strong toxicity when } \\
\text { expressed in Saccharomyces cerevisiae. }\end{array}$ & [226] \\
\hline L792 & $\mathrm{P}$ & $\begin{array}{l}\text { Its mutation caused gain of function mutation and weaker } \\
\text { toxicity when expressed in Saccharomyces cerevisiae. } \\
\text { Its mutation caused significant response to } \mathrm{pH} 6.4 \text { (threshold } \\
\text { concentration for proton-activation). }\end{array}$ & [226] \\
\hline L796 & $\mathrm{P}, \mathrm{V}$ & $\begin{array}{l}\text { Its mutation caused gain of function and strong/weaker toxicity } \\
\text { when expressed in Saccharomyces cerevisiae. }\end{array}$ & [226] \\
\hline S 800 & A & $\begin{array}{l}\text { Its phosphorylation by PKC potentiates CAPS, acid, and thermal } \\
\text { responses. }\end{array}$ & {$[74,81,233]$} \\
\hline
\end{tabular}


1 


\title{
Resiniferatoxin Mediated Ablation of TRPV1+ Neurons Removes TRPA1 as Well
}

\author{
László Pecze, Péter Pelsóczi, Miklós Kecskés, Zoltán Winter, András Papp, \\ Krisztián Kaszás, Tamás Letoha, Csaba Vizler, Zoltán Oláh
}

\begin{abstract}
Objectives: Resiniferatoxin, the most potent agonist of inflammatory pain/vanilloid receptor/cation channel (TRPV1) can be used for neuron subtype specific ablation of pain generating cells at the level of the peripheral nervous system by $\mathrm{Ca}^{2+}-\mathrm{excytotoxicity.}^{2}$ Molecular neurosurgery is an emerging technology either to alleviate severe pain in cancer or treat/prevent different local neuropathies. Our aim was determining sensory modalities that may be lost after resiniferatoxin treatment. Methods: Newborn or adult mice were treated with resiniferatoxin, then changes in chemical and heat sensitivity were correlated with alterations of the cell composition of sensory ganglions. Results: Only mice treated at adult age became less sensitive to heat stimuli, while both treatment groups lost sensitivity to specific vanilloid agonists of TRPV1 and, interestingly, to allyl-isothiocyanate, a selective agonist of TRPA1. Our in vivo and post mortem analytical results confirmed that TRPV1 and TRPA1 function together and resiniferatoxin-mediated neurosurgery removes both sensor molecules. Discussion: In adult mice resiniferatoxin causes: i) desensitization to heat and ii) sensitization to cold. Cold hyperalgesia, an imbalance in thermosensation, might be conferred by a prominent cold receptor that is expressed in surviving resiniferatoxin-resistant sensory neurons and compensates for pain signals lost with TRPA1 and TRPV1 double positive cells in the peripheral nervous system.
\end{abstract}

RÉSUMÉ: L'ablation de neurones TRPV1+ par la résinifératoxine élimine aussi les neurones TRPA1. Objectifs : La résinifératoxine, l'agoniste le plus puissant de la douleur inflammatoire/du récepteur vanillö̈de/du canal cationique (TRPV1), peut être utilisée pour l'ablation spécifique par excytotoxicité $\mathrm{Ca} 2+$, d'un sous-type de neurones faisant partie des cellules génératrices de douleur au niveau du système nerveux périphérique. La neurochirurgie moléculaire est une technologie émergente, pour soulager la douleur cancéreuse sévère ou pour traiter ou prévenir différentes neuropathies locales. Notre but était de déterminer les pertes sensitives suite au traitement par la résinifératoxine. Méthodes : Des souris ont été traitées par la résinifératoxine à la période néonatale ou adulte et les changements de la sensibilité chimique et calorique ont été corrélés aux altérations de la composition cellulaire des ganglions sensitifs. Résultats : Seules les souris traitées à l'âge adulte sont devenues moins sensibles aux stimuli caloriques alors que les deux groupes traités ont perdu la sensibilité aux agonistes vanilloïdes spécifiques de TRPV1 et, ce qui est fort intéressant, à l'allylisothiocyanate, un agoniste sélectif de TRPA1. Nos résultats d'analyses in vivo et post mortem ont confirmé que TRPV1 et TRPA1 fonctionnent conjointement et que la neurochirurgie au moyen de la résinifératoxine élimine les deux molécules détectrices. Discussion : Chez les souris adultes la résinifératoxine cause : 1) une désensibilisation à la chaleur et 2) une sensibilisation au froid. Une hyperalgésie au froid, qui est un déséquilibre dans la thermosensibilité, pourrait être médiée par un récepteur important au froid qui est exprimé dans les neurones sensitifs résistants à la résinifératoxine survivants et qui compense pour les signaux douloureux perdus des cellules doublement positives pour TRPA1 et TRPV1 dans le système nerveux périphérique.

Can. J. Neurol. Sci. 2009; 36: 234-241

Mammalian temperature sensors of the transient receptor potential (TRP) family are tetrameric 6-transmembrane cation channels gated by heat, cold, as well as either endogenous or exogenous agonists ${ }^{1,2}$. The vanilloid receptor (VR1/TRPV1) is a non-selective ligand-gated $\mathrm{Na}^{+} / \mathrm{Ca}^{2+}$-channel ${ }^{3-6}$. TRPV1 is selectively activated by heat above $42^{\circ} \mathrm{C}, \mathrm{pH}<6.3^{7}$, endogenous lipid mediators such as anandamide and oleoylethanolamide ${ }^{4,8,9}$, intracellular signaling molecules ${ }^{10,11}$ and plant toxins, including capsaicin (CAPS) and resiniferatoxin (RTX).

TRPA1 has recently been suggested to serve as receptor of noxious cold temperature ${ }^{12}$, and it transduces pain induced by isothiocyanate pharmacophore of the pungent ingredients of mustard oil ${ }^{11}$ and garlic ${ }^{13}$. However, various observations ${ }^{11,14,15}$

From the Institute of Biochemistry (LP, PP, MK, ZW, KK, TL, CV, ZO), Biological Research Center of the Hungarian Academy of Sciences, Department of Public Health (AP), Department of Medical Chemistry (TL), University of Szeged; Acheuron Hungary Ltd. (ZO), Szeged, Hungary.

Received August 18, 2008. Final Revisions Submitted October 27, 2008. Correspondence to: Csaba Vizler, BRC of HAS, Szeged, Hungary-6726, Temesvári krt 62. 
now call into question that TRPA1 is a bona fide cold sensor ${ }^{12,16,17}$, that prompted functional investigations, such as ours described here.

Resiniferatoxin, the most potent natural diterpene agonist of TRPV1, is present in latexes of various Euphorbia species, such as E. resinifera, E. poissoni and E. unispina ${ }^{18}$. Bioassays rank RTX as a 3-4 orders of magnitude more potent agonist of TRPV1 than CAPS, the active ingredient of chili pepper ${ }^{19}$. One of us proposed exploitation of the $\mathrm{Ca}^{2+}$-excytotoxic potential of RTX for pain management, using it as an ablative agent specific for TRPV1 expressing cells. In vivo RTX treatment eliminates TRPV1+ nociceptors in the peripheral nervous system while bystander neurons and their functions are spared ${ }^{4,20}$. Indeed, determination of specificity in vitro and in vivo in different animal models and human dorsal root ganglion cultures validated RTX as a "nano-scalpel" capable of "molecular neurosurgery" of specific inflammatory pain cells without affecting the other function-alities of the peripheral and central nervous system ${ }^{4,5,21}$.

Although vanilloids had been used previously in vivo ${ }^{22}$, we started to employ RTX in various routs of applications, such as systemic, epidural, intra-nerve and intra-ganglionic injections in adult ${ }^{5,23,24}$ as well as newborn rats (Olah, Karai, Iadarola, unpublished observation). Systematic studies with a therapeutic mechanisms in mind shifted the desensitization paradigm and identification of the vanilloid receptor have helped interpretation of long-term loss of response to thermal and stimuli evoked by noxious chemicals. Our selective ablation pain management technology by usurpation of nociceptive neurons for elimination of hyperalgesia and neurogenic inflammation is distinct from the desensitization theory proposed previously ${ }^{25}$. Resiniferatoxin is now a validated drug lead to remove TRPV1+ inflammatory pain generator cells. We demonstrated that RTX preserves bystander sensory cells and motoneurons in rats, dogs, monkeys and human embryonic dorsal root ganglion (DRG) cultures ${ }^{4,5,26,27}$.

Resiniferatoxin, although extremely specific to its target, TRPV1, can delete sensation modalities conferred by bystander sensor molecules, including other TRP channels co-expressed in the same neuron. Therefore, the specific aim of this study was to determine potential loss/gain of sensations that RTX-mediated molecular surgery may cause. Furthermore, previous to discovery of TRPV1 and TRPA1, it was routine to evaluate the pharmacological effects of vanilloids by mustard oil test. The discovery that allyl isothiocyanate is a cognate ligand of TRPA1 and not TRPV1 implies that this test only can work due to coexpression of these TRP channels. Since both TRPV1 and TRPA1 can evoke sterile inflammation, visualized by Evans Blue extravasation ${ }^{5,27}$, their functional loss induced by potent vanilloids could not be easily distinguished ${ }^{28}$. Story et al proposed that TRPA1 might be another cation channel coexpressed with TRPV $1^{12}$, but no systematic study has been carried out to verify this notion and reveal the functional consequences of co-deletion. According to our data in this paper, allyl isothiocyanate, the pungent ingredient in mustard oil, selectively targets TRPA1 only, and has no agonist side effect on TRPV1. In addition we also described the unenexpected effects of RTX treatment on cold sensitivity of the treated animals.

\section{Material And Methods}

\section{Reagents}

Resiniferatoxin (LC Laboratories, Woburn, MA) and capsaicin (Sigma, St. Louis, MO) were dissolved in ethanol and further diluted in physiological saline solution. Allyl isothiocyanate (AITC) (Sigma, St. Louis, MO) was diluted in physiological salt solution and dispergated by ultrasonication before testing.

\section{${ }^{45} \mathrm{Ca}^{2+}$ uptake assay}

One day before the assay, HaCaT cells permanently expressing rat TRPV $1{ }^{6}$ were seeded in 96 -well flat bottom plates (Orange Scientific, Braine-l'Alleud, Belgium) at a density of 20.000 cells/well. Assays were performed using a BioMek 1000 robotized liquid handler (Beckman Instruments, Fullerton, CA). The plates were washed three times with assay medium $\left(\mathrm{Ca}^{2+}-\right.$ and $\mathrm{Mg}^{2+}$-free Hanks' balanced salt solution supplemented with $0.8 \mathrm{mM} \mathrm{MgCl}$ and with $25 \mathrm{mM}$ TRIS-HCl, $\mathrm{pH}=7.4)$. The serial dilutions of reagents containing ${ }^{45} \mathrm{Ca}^{2+}$ were prepared using the robot. The ${ }^{45} \mathrm{Ca}^{2+}$-uptake assay was performed for ten minutes (m) at $24^{\circ} \mathrm{C}$ using $1.33 \mu \mathrm{Ci} / \mathrm{ml}$ of ${ }^{45} \mathrm{Ca}^{2+}$ (Amersham Biosciences, Buckinghamshire, UK) in $100 \mu \mathrm{l}$ final volume/well. To stop ${ }^{45} \mathrm{Ca}^{2+}$ uptake and remove the free isotope, cells were washed three additional times and then lysed in $80 \mu \mathrm{l} /$ well lysis buffer (50 mM Tris-HCl, pH 7.5, $150 \mathrm{mM} \mathrm{NaCl,} \mathrm{1 \%} \mathrm{Triton} \mathrm{X-}$ $100,0.1 \%$ SDS, $5 \mathrm{mM}$ EDTA) for 30 minutes. Seventy $\mu 1$ aliquots of the solubilized cell extracts were mixed with $100 \mu \mathrm{l}$ aliquots of Optiphase Supermix scintillation cocktail (Perkin Elmer, Wellesley, MA) and counted in a Perkin Elmer liquid scintillation counter.

\section{RTX treatment}

The studies were carried out on male $\mathrm{CD} / 1$ mice. One $\mathrm{mg}$ RTX was dissolved in $500 \mu \mathrm{l} 96 \%$ ethanol and diluted in physiological saline and injected s.c into the scruff of the neck in a volume of about $100 \mu \mathrm{l}$. The RTX was applied at the dosage of $50 \mu \mathrm{g} / \mathrm{kg}$ body weight under light ether anesthesia to avoid unnecessary pain. Control mice received vehicle. In the case of adult treatment, two to three months old adult mice weighing about $30 \mathrm{~g}$ at the start of the experiments were tested ten days after RTX treatment. Mice treated on the second day of life were tested at two months of age. In the case of chronic RTX treatment RTX was added at $20 \mu \mathrm{g} / \mathrm{kg}$ body weight daily for three days.

All animal experimental protocols were approved by our institutional review committee, then the responsible governmental agency.

\section{Cold tail-flick test}

Animals were held over ice cold water $\left(\sim 5^{\circ} \mathrm{C}\right)$ and their tails submerged approximately half length into the bath. The time from immersion to tail removal or flicking was measured.

\section{Cold plate test}

A microplate thermostate set at $5^{\circ} \mathrm{C}$ was used to generate a cold surface. Tested mice were placed on the plate, then time to 
first response of forelimbs withdrawal and shivering was recorded.

\section{Hot plate test}

The animals were individually exposed to the hot plate maintained at $53^{\circ} \mathrm{C}$. The time for forepaw licking was taken as reaction time.

\section{Water consumption}

The daily water consumption of individually housed mice was measured. Each bottle contained tap water with allyl isothiocyanate at a concentration of $0.1 \mathrm{mM}$.

\section{Eye wipe test}

The eye wipe test was performed in anaesthetized animals. The $100 \mu \mathrm{M}$ capsaicin solution and the $1 \mathrm{mM}$ AITC solution was dropped into the eye and the number of defensive wiping movements was counted.

\section{Production of a monoclonal antibody recognizing an extracellular loop of intact TRPV1}

BALB/c 3T3 cells expressing the rat TRPV1 driven by the metallothionein promoter of the pMET plasmid ${ }^{4}$ were induced with $75 \mu \mathrm{M} \mathrm{Zn}{ }^{2+}$ overnight. The induction resulted in a twofold elevation of vanilloid-induced Ca-uptake measured in a robotized ${ }^{45} \mathrm{Ca}^{2+}$ uptake assay. The TRPV1 overexpressing cells were homogenized, the debris was removed by centrifuging, then the homogenization and centrifuging steps were repeated once more. The cell membrane fraction was recovered by ultracentrifuging the supernatant. After determination of the protein content, the aliquotted cell membrane suspension was stored at $-85^{\circ} \mathrm{C}$. BALB/c mice were injected with $100 \mu \mathrm{l}$ membrane suspension containing $300 \mu \mathrm{g}$ total protein mixed with $100 \mu \mathrm{l}$ complete Freund's adjuvant, then the immunization was repeated three times using incomplete Freund's adjuvant. A last boost was given in the form of an ip injection of $100 \mu \mathrm{l}$ membrane homogenate and three days later spleen cells of the immunized mice were fused with $\mathrm{SP} / 2$ myeloma cells. A hybridoma clone producing antibody to an extracellular loop of the intact TRPV1 molecule was selected by testing pooled, then individual hybridoma supernatants on intact TRPV1-expressing $3 \mathrm{~T} 3$ cells by flow cytofluorometry using a FITC labeled antimouse secondary antibody. The resulting hybridoma clone was verified to produce a monoclonal antibody recognizing the intact rat TRPV1 expressed by the transformed 3T3 cell line, as well as the naturally expressed molecule in rat or mouse trigeminal ganglion or the prostate. The monoclonal antibody was directly labeled with green fluorescence using Alexa Fluor 488 Monoclonal Antibody Labeling Kit (Invitrogen, Carlsbad, CA,).

\section{Protein Extraction and Western Blot}

Tissue samples were homogenized in modified RIPA buffer (50 mM Tris-HCl, $140 \mathrm{mM} \mathrm{NaCl,} 5 \mathrm{mM}$ EDTA, 1\% TritonX100, Protease Inhibitor Cocktail - Roche, Mannheim, Germany) and incubated on ice for 15 minutes to let lysis proceed. All samples were precleared by centrifugation $\left(15^{\prime} 12000 \mathrm{~g}\right.$ at $\left.4^{\circ} \mathrm{C}\right)$ before determining protein concentrations using the bicinchonic acid (BCA) method (Sigma, St. Louis, MO). PAGE was done as described in the Protein Electrophoresis technical manual of Amersham Biosciences (Buckinghamshire, UK). Protein samples were separated on $8 \%$ polyacrylamide gels, then transferred to Millipore Immobilon PVDF membrane using TrisGlycine transfer buffer (0.192 M Glycine, $25 \mathrm{mM}$ Tris, $20 \%$ $\mathrm{MetOH})$. Transfer was followed by blocking of the membrane (30' at RT in 5\% dry milk TBS-T), incubation with primary antibody (overnight at $4^{\circ} \mathrm{C}$, in $0.5 \%$ BSA TBS-T), secondary antibody ( $2 \mathrm{~h}$ at $\mathrm{RT}$, in $1 \%$ dry milk TBS-T), results were revealed using the ECL method (SuperSignal West Chemiluminescent Substrate (Pierce Biotechnology Inc. Rockford, IL), Hyperfilm ECL - Amersham Biosciences, Buckinghamshire, UK). TBS: $50 \mathrm{mM}$ Tris, $140 \mathrm{mM} \mathrm{NaCl}, \mathrm{pH}$ 7.6; TBS-T: TBS with $0.5 \%$ Tween-20. Antibodies used and their dilutions: TRPV1 - 1:1000, ABR Bioreagents, PA1-747; TRPA1 - 1:1000, Transgenic Inc. Kumamoto, Japan. \#KM120; TRPM8 - 1:1000, Alomone Labs, Jerusalem, Israel \#ACC-049, ß-actin - 1:1000 (Sigma, St. Louis, MO \#A5060), anti-mouse and anti-rabbit HRP - 1:10000 (Sigma, St. Louis, MO \#A0168 and \#A6154, respectively).

\section{Immunhistochemistry}

Over-anesthesized mice were perfused intracardially with $4 \%$ paraformaldehyde in $0.1 \mathrm{M}$ sodium phosphate buffer $(\mathrm{PB}, \mathrm{pH}$ 7.4). Trigeminal ganglions were dissected out, and cryoprotected in $10 \%$ glycerol $/ 30 \%$ sucrose) overnight at $4^{\circ} \mathrm{C}$. Trigeminal ganglions were embedded in Tissue Tek OCT (Sakura Finetek, Torrance, CA) and frozen in dry ice. Frozen sections were cut on an Shandon Cryotome Fe (Thermo Fisher Middletown, VA) sliding microtome and collected in Superfrost slides kept at $20^{\circ} \mathrm{C}$. Sections were pre-incubated in blocking solutions $(5 \%$ goat serum, $0,1 \%$ Triton-X in PBS $\mathrm{pH}=7.4$ ). After that the sections were incubated in primary antibody dilutions at $4{ }^{\circ} \mathrm{C}$ for 24 hours then secondary antibody. Antibodies used and their dilutions: anti-TRPV1 1:50 (our monoclonal antibody directly labeled with Alexa Fluor 488), anti TRPA1 1:50 (rabbit polyclonal, Transgenic Inc. Kumamoto, Japan. \#KM120) anti TRPM8 1:50 (rabbit polyclonal, Alomone Labs, Jerusalem, Israel \#ACC-049) anti rabbit IgG - TRITC 1:400 (Sigma, St. Louis, MO) . Sections were mounted on standard glass slides and coverslipped with Dako Faramount Aqueous Mounting Medium (Dako, Glostrup, Denmark).

\section{RESULTS}

To determine the potential effect of allyl isothiocyanate in vitro we used a cell-based functional assay using a permanent cell line expressing TRPV1 but not TRPA1 ectopically. Resiniferatoxin and CAPS evoked ${ }^{45} \mathrm{Ca}$-influx with an $\mathrm{EC}_{50}$ of $2.6 \mathrm{nM}$ and $78 \mathrm{nM}$, respectively (Figure 1). Contrary to the report of Ohta et $\mathrm{al}^{29}$, however, we found that allyl isothiocyanate has no effect on TRPV1-expressing cells, since it did not evoke calcium influx applied at concentrations ranging from $125 \mathrm{nM}$ to $2.5 \mathrm{mM}$. Lack of AITC effect on TRPV1 and selectivity of this ligand for TRPA1, has recently been shown by others too ${ }^{11,16}$.

To dissect potential side effect(s) of molecular neurosurgery in vivo, mice were treated with RTX either at birth or at adult age 


\section{TRPV1/HaCaT}

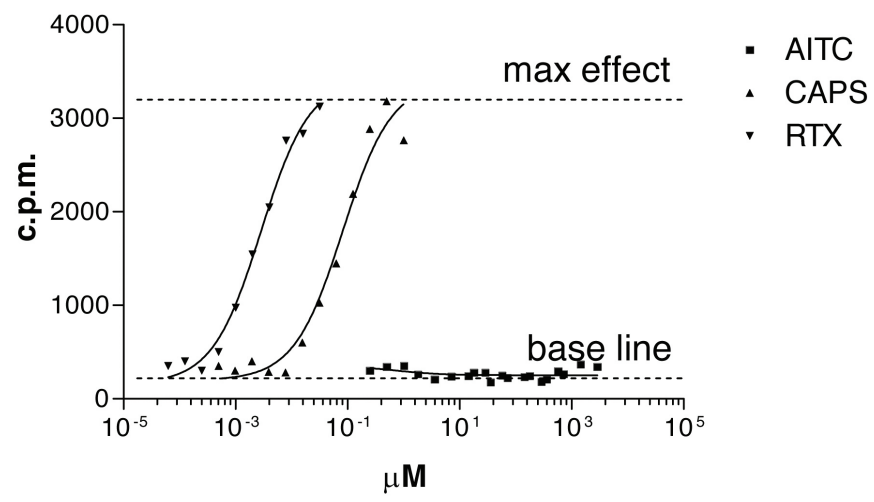

Figure 1: ${ }^{45} \mathrm{Ca}^{2+}$-influx induced by resiniferatoxin (RTX), capsaicin (CAPS) and allyl isothiocyanate (AITC). HaCaT keratinocytes stably expressing rat TRPV1 were seeded on 96-well plates, then ten-minute agonist induced ${ }^{45} \mathrm{Ca}^{2+}$-influx assays were performed. Cell-bound radioactivity was measured in a liquid scintillation counter. Only RTX and CAPS induced a Ca-influx, while AITC was totally ineffective. The experiment was repeated two additional times with similar results. then changes in behavioral, cellular, and molecular biomarkers (i.e. chemo-, and heat sensitivity, tissue specific expression/ distribution of TRPV1 and TRPA1) were systematically compared.

As expected from previous studies ${ }^{5}$, mice treated with RTX two days post-natal and tested at the age of two months completely lost the sensitivity to vanilloids, since capsaicininduced eye wipe, a behavioral marker of TRPV 1 conferred pain signal, was completely abrogated. We have chosen an RTX dose at which no mortality occurred. In our experimental conditions applied in preliminary experiments, RTX-caused mortality was detected from $75 \mu \mathrm{g} / \mathrm{kg}$ body weight, while the maximal dose used in the paper was $50 \mu \mathrm{g} / \mathrm{kg}$ body weight. We also noted that mice were unresponsive in AITC-induced eye wipe tests as well, as the AITC-induced eye wipes were completely abrogated. In accordance with that fact, these animals consumed AITC containing drinking water in a significantly higher volume overnight than untreated mice $(2.7 \pm 1.7 \mathrm{ml}$ vs $5.5 \pm 1.5 \mathrm{ml})$, another signature of specific loss of this sensory modality.

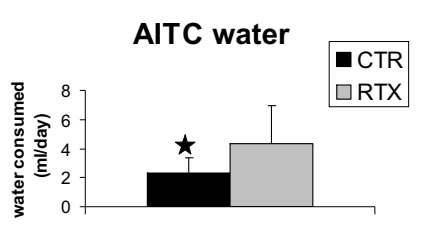

CAPS eye wipe test

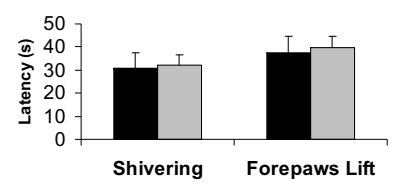

Hot plate test
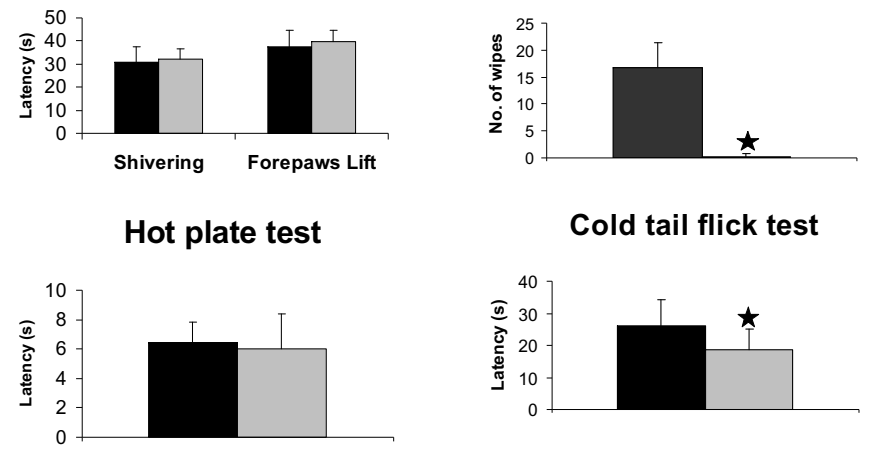

Cold tail flick test

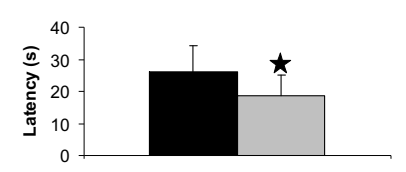

Figure 2: Changes in the chemical-and heat sensitivity of mice treated with resiniferatoxin at $50 \mu \mathrm{g} / \mathrm{kg}$ body weight on the second day after birth. Mice were tested at second month of their life. Comparisons were made using age-matched control animals treated with vehicle only. Bars represent means of measured values plus standard deviations $(n=7)$. The experiments were repeated two additional times with similar results. A.) Oral aversion to allyl isothiocyanate (AITC; mustard oil). Treated mice consumed significantly more allyl isothiocyanate containing drinking water than untreated mice in a 24 h test. $* P<0.05$ vs. control B-C.) Eyewipe response to corneal application of $100 \mu \mathrm{M}$ capsaicin and $10 \mathrm{mM}$ allyl isothiocyanate. Neonatal RTX administration significantly reduced the eye-wipe response to corneal application of capsaicin and also to allyl isothiocyanate. ${ }^{*} P<0.05$ vs. control. D.) Cold plate test. Paw withdrawal latency (left) or time to first shiver (right) were measured following placement of mice on a plate maintained at $5^{\circ} \mathrm{C}$. Responses were not significantly different. E.) Response latency in the tail immersion into $4^{\circ} \mathrm{C}$ cold water. No significant differences were seen between control and RTX treated animals. F) Licking latencies in the hot plate assay at $53^{\circ} \mathrm{C}$. The responses were not significantly different.

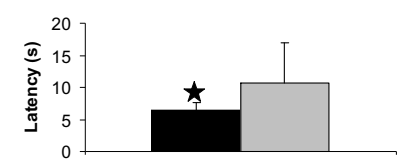

Figure 3: Changes in the chemical-and heat sensitivity of mice treated with $50 \mu \mathrm{g} / \mathrm{kg}$ resiniferatoxin at adult age. Mice were tested two weeks later. Comparisons were made using age matched control animals treated with vehicle only. Bars represent means plus standard deviations $(n=7)$. The experiments were repeated two additional times with similar results. A.) Oral aversion to allyl isothiocyanate (AITC). Treated mice consumed significantly more allyl isothiocyanate containing drinking water than untreated mice in $24 \mathrm{~h}$ tests. $* P<0.05 \mathrm{vs}$. control $B$ - $C$.) Eyewipe response to corneal application of $100 \mu \mathrm{M}$ capsaicin and $10 \mathrm{mM}$ allyl isothiocyanate. RTX administration significantly reduced the eyewipe response to corneal application of capsaicin and allyl isothiocyanate. $* P<0.05$ vs. control. D.) Cold plate test. Paw withdrawal latency (left) or time to first shiver (right) was measured following placement of mice on a plate maintained at $5^{\circ} \mathrm{C}$. Treated mice showed more sensitivity to cold. $* P<0.0001$ vs. control. E.) Response latency in the tail immersion into $4^{\circ} \mathrm{C}$ cold water. Significant differences were seen between control and RTX treated animals. $* P<0.05$ vs. control. F) Licking latencies in the hot plate assay at $53^{\circ} \mathrm{C}$ Responses were significantly different. RTX treated animals had longer reaction times. ${ }^{*} p<0.05$ vs. control. 


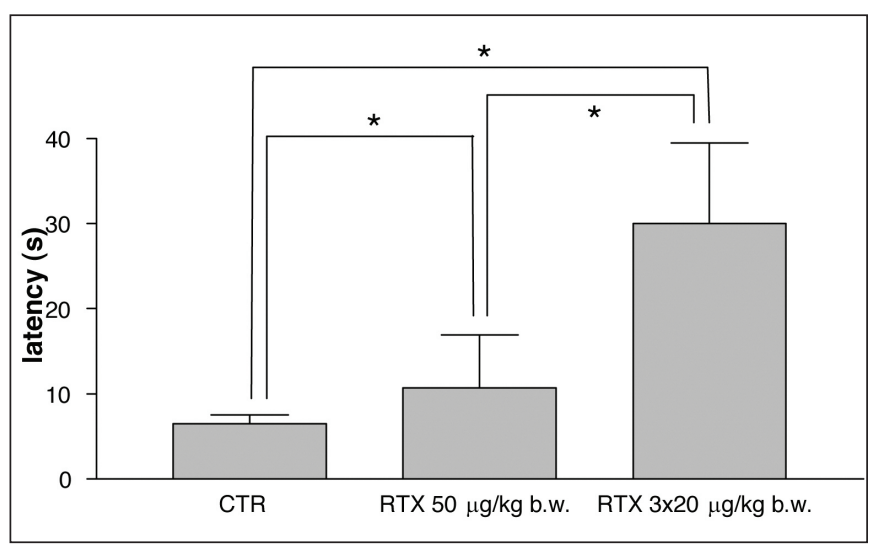

Figure 4: Comparison of acute and chronic RTX treatment. Chronic RTX ( $3 \times 20 \mu \mathrm{g} / \mathrm{kg}$ body weight) is more effective than acute treatment $(1 \times 50$ $\mu \mathrm{g} / \mathrm{kg}$ body weight) as measured in hot plate assay. Bars represent means plus standard deviations. Statistics were made by LSD post hoc test following one-way ANOVA, $* P<0.05$ vs. control.

Interestingly, they showed no change in temperature sensitivity neither in cold plate, nor in hot plate assay (Figure 2).

Mice treated with one dose of RTX at adult age become similarly unresponsive to chemical stimuli, i.e., they did not respond either to CAPS or AITC in the eye wipe tests, and they were also able to consume AITC containing drinking water in high quantities. In addition, the animals that underwent RTXmediated neurosurgery at adult age exhibited changes of heat sensitivity. As it was expected from previous observations ${ }^{5}$, loss of TRPV1-expressing neurons resulted in decreased heat sensitivity. Surprisingly, however, the RTX-treated animals also become more sensitive to cold, showing a marked reduction of reaction time (around 30\%) on cold plate as measured in cold plate tail flick and cold plate shivering tests (Figure 3).

In the case of chronic RTX treatment $(3 \times 20 \mu \mathrm{g} / \mathrm{kg}$ body weight rather than $1 \times 50 \mu \mathrm{g} / \mathrm{kg}$ body weight) mice become similarly unresponsive to CAPS. However these mice lost heat sensitivity to a higher extent compared to mice with acute treatment, so chronic treatment seemed to be more effective than a single treatment in this respect (Figure 4).

Immunohistological staining experiments performed on adult mice treated with $1 \times 50 \mu \mathrm{g} / \mathrm{kg}$ body weight RTX confirmed that TRPV1 is indeed lost after the treatment. The staining was performed with a new monoclonal antibody developed in our laboratory. Our hybridoma cell line was established from a normal $\mathrm{BALB} / \mathrm{c}$ mouse immunized previously with a crude plasma membrane fraction isolated from a BALB/c $3 T 3$ cell line permanently expressing the rat TRPV1. By employing indirect fluorescent labeling technologies, the monoclonal antibody was verified to react with an extracellular loop of both rat and mouse TRPV1. Parallel to TRPV1, TRPA1 also disappeared from the trigeminal ganglions of the RTX treated animals (Figure 5), but the TRPM8-positive cells remained readily detectable. TRPA1 and TRPM8 were stained with commercially available antibodies.
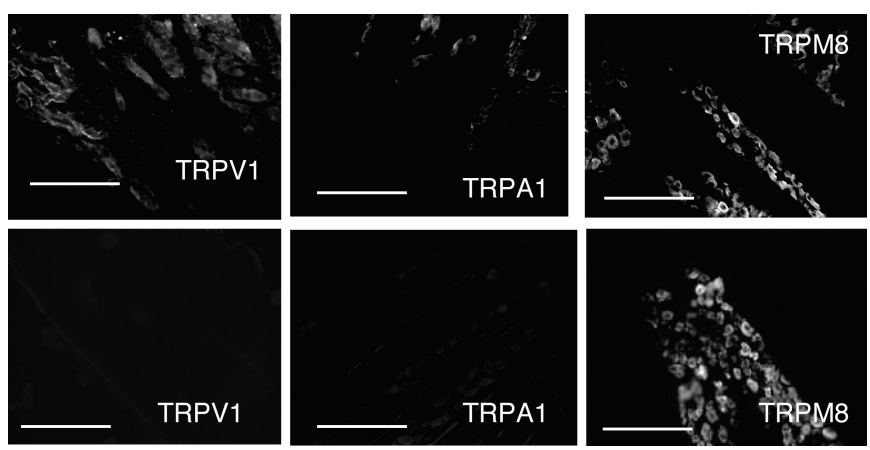

Figure 5: Microscopic images showing the effect of RTX on TRPV1-, TRPA1- and TRPM8-positive trigeminal ganglion neurons. Unlike TRPM8, both TRPV1 and TRPA1 immunoreactivity was lost in the treated animals. Bar represents: $0.2 \mathrm{~mm}$.

\begin{tabular}{|l|}
\hline RTX: -+ \\
\hline TRPV-1 - \\
TRPA-1 - \\
TRPM-8 - \\
ß-actin
\end{tabular}

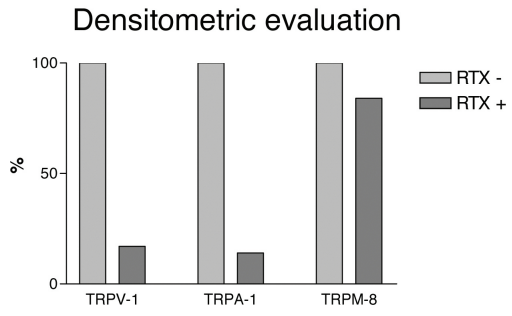

Figure 6: Western blot analysis. Western blot shows the level of TRPV1, TRPA1 and TRPM8 proteins in the lysates of pooled trigeminal ganglions obtained from control and RTX treated mice. Similarly to TRPV1, TRPA1 also disappears from the trigeminal ganglions of treated animals, while TRPM8 does not change. Sigma beta-actin was used in the Western blot as an internal control.

The correlation between TRPV1 and TRPA1 levels in the dorsal root ganglion and trigeminal ganglion with the changes in chemical and heat sensitivity in mice treated at adult age was tested in Western blot experiments. In this case, TRPV1, TRPA1 and TRPM8 were immunostained with commercially available polyclonal antibodies. Our Western blot experiments confirmed that, parallel to TRPV1, TRPA1 also disappeared from the trigeminal ganglions of the RTX treated animals; the decrease was $83 \%$ in the case of TRPV1, while $86 \%$ in the case of TRPA1, while the amount of TRPM8 barely, non-significantly changed (Figure 6).

\section{Discussion}

Recently one of us proposed a novel use of RTX as pain killer drug $^{5}$. Being at least a thousand fold more potent analogue of CAPS, RTX applied either intrathecally or intraganglionically can execute a highly specific TRPV1 targeted molecular neurosurgery to eliminate cellular generator of inflammatory as 
well as cancer pain ${ }^{4,5}$. According to literature data, 24 hours after CAPS treatment a population of primary sensory neurons of newborn ${ }^{30}$ and adult rats ${ }^{31}$ show TUNEL staining, indicating that neurons are killed by apoptosis. Likewise CAPS, RTX, due to 34 magnitudes more potent agonist activity on TRPV1 can induce $\mathrm{Ca}^{2+}$-cytotoxicity and eventually ablates these neurons by rapid necrosis, followed by removal of the cell debris $4,5,21,24$.

Resiniferatoxin has been shown to eliminate inflammatory pain by specific $\mathrm{Ca}^{2+}$-cytotoxicity in newborn ${ }^{25}$ as well as in adult rats $^{5}$, and it had an anti-nociceptive effect in adult mice ${ }^{32}$, monkeys $\mathrm{s}^{27}$ and $\operatorname{dog}^{26}$. A number of in vitro and vivo experiment has already validated safety and efficacy of molecular neurosurgery management of arthritic and cancer pain, even in large animals such as dogs and monkeys, promoting human trials and registration of RTX as an alternative drug in pain inflammation and various neuropathy indications ${ }^{26,27}$. Contrary to TRPV1 antagnists, also in development as painkillers, intraganglional or intrathecal RTX treatment would provide a permanent solution to incurable chronic pain.

Resiniferatoxin treatment manifests in mice, as in other experimental animals, in drastic loss of sensitivity to noxious chemicals and coincident drop out of TRPV1+ nociceptive neuronal bodies in sensory ganglia. Results in mice not only give another reassuring validation of the molecular neurosurgery technolog $y^{4,5,24}$, but prompted us to develop the first monoclonal antibody for better diagnosis of cell type specific drop out ${ }^{4}$. Convincing decrease in number of small and medium size TRPV1+ neuron counts has been determined in RTX treated mice also cross-validated specificity of our novel monoclonal antibody. Moreover, we found that RTX-treated mice also showed loss of TRPA1-dependent chemical sensitivity, confirming previous obser-vations that TRPV1 indeed coexpresses with TRPA1 in a number of nociceptive neurons in the peripheral nervous system. The eventual effect of RTX on TRPA1 is excluded by previous publications. For example, cultured DRG neurons of TRPV-/- mice did not show stimulusevoked rise in intracellular free $\mathrm{Ca}$ in response to resiniferatoxin, proving that none of the remaining TRP receptors is vanilloidsensitive $^{33}$. In addition, iodo-resiniferatoxin did not interefere with DRG neuron activation in response to TRPA1 agonists ${ }^{34}$, confirming that TRPA1 does not bind vanilloids ligands. We can conclude that RTX-mediated molecular neurosurgery eliminates most or all TRPA1-containing neurons as well via TRPV1 activation, as it is indicated by and the almost complete loss specific immunoreactivity in sensory nociceptors.

The RNA diagnostics with RT-PCR technology in DRG samples from RTX-treated and untreated rats have shown significant decrease of both receptors ${ }^{35}$. Observation in these studies extends and corroborates results of Ruparel and coworkers that allyl-isothiocyanate, a selective agonist of TRPA1, can heterologously inactivate TRPV1, probably located in the same nociceptor neurons ${ }^{36}$. However, Ruparel et al interpreted their results as consequence of TRPV1 desensitization involving signaling events. Although transient, functional desensitization based on signalling events might also be induced by low dose vanilloids in other models ${ }^{37,38}$, in our case RTX treatment obviously induces the loss of both TRPV $1^{+}$and TRPA $1^{+}$ neurons. As we have confirmed, the treated animals become insensitive to vanilloids for a lifetime, indicating that the mechanism is indeed deletion-, and not signaling-based. Since RTX treated mice are also insensitive to allyl-isothiocyanate, that only can happen if TRPA1 expression is coincident with TRPV1 expression in the vast majority of nociceptive neurons that normally confer pain signal to endogenous substances produced in pain and inflammation.

Co-ablation of $\mathrm{TRPV}^{+}$neurons with TRPA1/allylisothiocyanate receptors by the RTX treatment have been circumstantially verified in experiments carried out in TRPV1 knockouts. In concert with evidences here, TRPV $1^{-/-}$genotyped mice still express TRPA1 in their inflammatory pain sensor neurons, thus preserve sensitivity to allyl-isothiocyanate ${ }^{39}$ and behave like wild-types.

The neuron subtype specificity of TRPA 1 was characterized by Story and co-workers as well in cell cultures ${ }^{12}$ and they noted that TRPM8 is expressed in a distinct cell population. Moreover, vast majority of TRPA1-positive cells showed co-localization with the CGRP neuropeptide, another prominent biomarker of TRPV $1^{+}$inflammatory pain-sensing neurons. Based on these data, two markedly distinct populations of cold-responsive neurons can be distinguished: i) TRPM8-positive neurons that lack of TRPV1 and TRPA1 expression and resistant to RTX treatment and ii) TRPA1-positive neurons that express TRPV1 as well and can be deleted either with allyl-isothiocyanate or RTX. Adult mice, treated with RTX as newborn, had an impaired response to both CAPS and AITC in eye-wipe tests and agonistlaced water consumption assays. In hot-plate experiments, reaction time of the treated animals was not significantly different from that of normal controls. Similar to our results, however, Gamse et al have found that mice treated with CAPS as newborns had normal reaction times either on the hot plate or in tail withdrawal latency tests. In contrast, mice treated at adulthood had greatly prolonged latencies in both thermal sensitivity. Thus, responses to noxious chemicals in adulthood were only moderately inhibited in mice treated as newborn, but almost completely abolished if the vanilloid was administered to adults $^{40}$.

Nociceptive thresholds reported in neonatal CAPS-treated animals are apparently contradictory. Several groups have found small increase in thermal nociceptive threshold ${ }^{28,41}$ but others reported little if any effect in hot plate tests ${ }^{42,43}$. It was reported that perineural resiniferatoxin selectively inhibits inflammatory hyperalgesia ${ }^{44}$. We have determined in serial experiments that the heat threshold increase depends on the efficacy of the RTX treatment; heat insensitivity of the animal becomes more pronounced if RTX ablates TRPV $1^{+}$nociceptors almost completely. Chronic, repeated RTX gave the best results while neonatal treatments were less effective.

Based on comparative data collected from TRPV1-null mice (little ${ }^{33}$ or no effect ${ }^{45}$ in hot plate test), we can conclude that there might be additional heat receptors. The complete lack of signal transmitted by TRPV1 positive neurons leads to the most complete heat insensitivity in mice lacking TRPV1+ neurons rather than the TRPV1 receptor only.

Previously, Obata et al noted that inflammation and nerve injury increases expression of TRPA1, but not TRPM8, in DRG neurons. Occurrence of cold hyperalgesia coincided with nerve growth factor (NGF)-induced up-regulation of TRPA1 in distinct set of sensory neurons ${ }^{46}$. Moreover, Katsura et al with intrathecal 
administration of an anti-sense-oligo specific for TRPA1 could suppress the nerve-ligation-induced cold hyperalgesia, but antiTRPM8 had little or any effect ${ }^{47}$. Contrary to these observations we found that not TRPA1 but TRPM8 is the main cold sensor. To explain this unexpected finding, at least two alternative hypothesizes can be made.

First, following to RTX-mediated neuronal drop out the intense arborization of resistant nerve endings can produce NGF, a validated exocrine transducer of gene inducer in nerve injury and might cause over-expression of TRPM8, a prominent cold pain signal transducer, as verified by others ${ }^{48}$. In fact, upon inflammations and nerve injuries, nociceptors' and thermoceptors' NGF expression is known to induced that correlates with sensitization to cold and allodynia ${ }^{49,50}$. Intraplantar injection of CAPS produces a transient thermal and mechanical hyperalgesia within three to six hrs, that disappears by 24 hours. Interestingly, CAPS injection upregulates proinflammatory cytokines and NGF within 1 hour, then cytokine levels return to control levels ${ }^{51}$. However, we have not found upregulation of TRPM8 channel in RTX treated mice using Western blot and RT-PCR. In accordance with that, DRG samples from RTX-treated and untreated rats have not shown significant change on the TRPM8 level ${ }^{35}$.

On the other hand, sensory stimuli are known to "compete" with each other for representation at the level of brain, for example, blind individuals have better auditory ability than sighted subjects, a mechanism that apparently compensates for loss of vision ${ }^{52}$. Analogously, cold hypersensation might confer an imbalance in the representation of sensory stimuli signaling heat and cold at the levels of the CNS. Due to neuronal plasticity, mice treated at neonatal age most likely can compensate for the imbalance caused by that drop out of C-type afferents neurons, while effect of RTX treatment in adulthood can not be compensated by "fine-tuning".

Importantly, experimental data in this paper predict a shift in heat perception in humans following RTX injection, as conceptualized in the clinical trial protocol to treat severe cancer pain. Similar changes might be expected during application of reversible, specific inhibitors of TRPV1, currently in development by different pharmaceutical companies. Such behavioral change, however, was not obvious in cancer/arthritis patient dogs treated via the intrathecal rout of application ${ }^{26}$, neither in monkeys, targeted with this molecular neurosurgery agent at the trigeminus ganglion ${ }^{27}$. Nevertheless, clinical trial of RTX in cancer pain patients may provide the answers to this question via thorough monitoring of potential change in cold sensation if it may happen in human at all.

\section{ACKNOWLEDGEMENTS}

ZO was supported by MC-IRG030854-PAINKILLER; Anyos Jedlik Program NKFP-1-00019/2005; GVOP-3.3.1-05/1.-200505-0057/3.0. TL was also supported by grants of the National Office for Research and Technology (OMFB-01576/2006 and OMFB-01630/2006) and the Zoltan Magyary Postdoctoral Fellowship Fund. CV was supported by grants the National Office for Research and Technology (OM-00051/2005 and OMFB-01575/2006) and the Hungarian Ministry of Health (552/2006). This paper was supported by the János Bolyai Research Scholarship of the Hungarian Academy of Sciences.

\section{REFERENCES}

1. Toth A, Boczan J, Kedei N, Lizanecz E, Bagi Z, Papp Z, et al. Expression and distribution of vanilloid receptor 1 (TRPV1) in the adult rat brain. Brain Res Mol Brain Res. 2005 Apr 27;135(12):162-8.

2. Tominaga M, Caterina MJ. Thermosensation and pain. J Neurobiol. 2004 Oct;61(1):3-12.

3. Caterina MJ, Schumacher MA, Tominaga M, Rosen TA, Levine JD, Julius D. The capsaicin receptor: a heat-activated ion channel in the pain pathway. Nature. 1997 Oct 23;389(6653):816-24.

4. Olah Z, Szabo T, Karai L, Hough C, Fields RD, Caudle RM, et al. Ligand-induced dynamic membrane changes and cell deletion conferred by vanilloid receptor 1 . J Biol Chem. 2001 Apr 6;276 (14):11021-30

5. Karai L, Brown DC, Mannes AJ, Connelly ST, Brown J, Gandal M, et al. Deletion of vanilloid receptor 1-expressing primary afferent neurons for pain control. J Clin Invest. 2004 May; 113(9):1344-52.

6. Olah Z, Josvay K, Pecze L, Letoha T, Babai N, Budai D, et al. Anticalmodulins and tricyclic adjuvants in pain therapy block the TRPV1 channel. PLoS ONE. 2007;2(6):e545.

7. Tominaga M, Caterina MJ, Malmberg AB, Rosen TA, Gilbert H, Skinner K, et al. The cloned capsaicin receptor integrates multiple pain-producing stimuli. Neuron. 1998 Sep;21(3): 531-43.

8. Suardiaz M, Estivill-Torrus G, Goicoechea C, Bilbao A, Rodriguez de Fonseca F. Analgesic properties of oleoylethanolamide (OEA) in visceral and inflammatory pain. Pain. 2007 Dec15;133(13):99-110.

9. Re G, Barbero R, Miolo A, Di Marzo V. Palmitoylethanolamide, endocannabinoids and related cannabimimetic compounds in protection against tissue inflammation and pain: potential use in companion animals. Vet J. 2007 Jan;173(1):21-30.

10. Olah Z, Karai L, Iadarola MJ. Protein kinase C(alpha) is required for vanilloid receptor 1 activation. Evidence for multiple signaling pathways. J Biol Chem. 2002 Sep 20;277(38):35752-9.

11. Jordt SE, Bautista DM, Chuang HH, McKemy DD, Zygmunt PM, Hogestatt ED, et al. Mustard oils and cannabinoids excite sensory nerve fibres through the TRP channel ANKTM1. Nature. 2004 Jan 15;427(6971):260-5.

12. Story GM, Peier AM, Reeve AJ, Eid SR, Mosbacher J, Hricik TR, et al. ANKTM1, a TRP-like channel expressed in nociceptive neurons, is activated by cold temperatures. Cell. 2003 Mar 21; 112(6):819-29.

13. Bautista DM, Movahed P, Hinman A, Axelsson HE, Sterner O, Hogestatt ED, et al. Pungent products from garlic activate the sensory ion channel TRPA1. Proc Natl Acad Sci USA. 2005 Aug 23;102(34): 12248-52.

14. Babes A, Zorzon D, Reid G. Two populations of cold-sensitive neurons in rat dorsal root ganglia and their modulation by nerve growth factor. Eur J Neurosci. 2004 Nov;20(9):2276-82.

15. Nagata K, Duggan A, Kumar G, Garcia-Anoveros J. Nociceptor and hair cell transducer properties of TRPA1, a channel for pain and hearing. J Neurosci. 2005 Apr 20;25(16):4052-61.

16. Bandell M, Story GM, Hwang SW, Viswanath V, Eid SR, Petrus MJ, et al. Noxious cold ion channel TRPA1 is activated by pungent compounds and bradykinin. Neuron. 2004 Mar 25;41 (6):849-57.

17. Sawada Y, Hosokawa H, Hori A, Matsumura K, Kobayashi S. Cold sensitivity of recombinant TRPA1 channels. Brain Res. 2007 Jul 30;1160:39-46.

18. Hergenhahn M, Kusumoto S, Hecker E. On the active principles of the spurge family (Euphorbiaceae). V. Extremely skin-irritant and moderately tumor-promoting diterpene esters from Euphorbia resinifera Berg. J Cancer Res Clin Oncol. 1984;108 (1):98-109.

19. Szallasi A, Blumberg PM. Resiniferatoxin, a phorbol-related diterpene, acts as an ultrapotent analog of capsaicin, the irritant constituent in red pepper. Neuroscience. 1989;30(2):515-20.

20. Caudle RM, Karai L, Mena N, Cooper BY, Mannes AJ, Perez FM, et al. Resiniferatoxin-induced loss of plasma membrane in vanilloid receptor expressing cells. Neurotoxicology. 2003 Dec; 24(6):895-908. 
21. Zhou HY, Zhang HM, Chen SR, Pan HL. Increased nociceptive input rapidly modulates spinal GABAergic transmission through endogenously released glutamate. J Neurophysiol. 2007 Jan;97 (1):871-82

22. Goso C, Piovacari G, Szallasi A. Resiniferatoxin-induced loss of vanilloid receptors is reversible in the urinary bladder but not in the spinal cord of the rat. Neurosci Lett. 1993 Nov 12;162(12): $197-200$.

23. Pan HL, Khan GM, Alloway KD, Chen SR. Resiniferatoxin induces paradoxical changes in thermal and mechanical sensitivities in rats: mechanism of action. J Neurosci. 2003 Apr 1;23(7):2911-9.

24. Szabo T, Olah Z, Iadarola MJ, Blumberg PM. Epidural resiniferatoxin induced prolonged regional analgesia to pain. Brain Res. 1999 Sep 4;840(1-2):92-8.

25. Szallasi A, Szallasi Z, Blumberg PM. Permanent effects of neonatally administered resiniferatoxin in the rat. Brain Res. 1990 Dec 24;537(1-2):182-6.

26. Brown DC, Iadarola MJ, Perkowski SZ, Erin H, Shofer F, Laszlo $\mathrm{KJ}$, et al. Physiologic and antinociceptive effects of intrathecal resiniferatoxin in a canine bone cancer model. Anesthesiology. 2005 Nov;103(5):1052-9.

27. Tender GC, Walbridge S, Olah Z, Karai L, Iadarola M, Oldfield EH, et al. Selective ablation of nociceptive neurons for elimination of hyperalgesia and neurogenic inflammation. J Neurosurg. 2005 Mar;102(3):522-5.

28. Jancso G, Jancso-Gabor A. Effect of capsaicin on morphine analgesia--possible involvement of hypothalamic structures. Naunyn Schmiedebergs Arch Pharmacol. 1980 Apr;311(3): 285-8.

29. Ohta T, Imagawa T, Ito S. Novel agonistic action of mustard oil on recombinant and endogenous porcine transient receptor potential V1 (pTRPV1) channels. Biochem Pharmacol. 2007 May 15;73 (10):1646-56.

30. Jin HW, Ichikawa H, Fujita M, Yamaai T, Mukae K, Nomura K, et al. Involvement of caspase cascade in capsaicin-induced apoptosis of dorsal root ganglion neurons. Brain Res. 2005 Sep $21 ; 1056(2): 139-44$

31. Czaja K, Burns GA, Ritter RC. Capsaicin-induced neuronal death and proliferation of the primary sensory neurons located in the nodose ganglia of adult rats. Neuroscience. 2008 Jan23; 154(2):621-30

32. Elekes K, Helyes Z, Nemeth J, Sandor K, Pozsgai G, Kereskai L, et al. Role of capsaicin-sensitive afferents and sensory neuropeptides in endotoxin-induced airway inflammation and consequent bronchial hyperreactivity in the mouse. Regul Pept. 2007 Jun 7;141(1-3):44-54.

33. Caterina MJ, Leffler A, Malmberg AB, Martin WJ, Trafton J, Petersen-Zeitz KR, et al. Impaired nociception and pain sensation in mice lacking the capsaicin receptor. Science. 2000 Apr 14;288(5464):306-13.

34. Taylor-Clark TE, Undem BJ, Macglashan DW, Jr., Ghatta S, Carr MJ, McAlexander MA. Prostaglandin-induced activation of nociceptive neurons via direct interaction with transient receptor potential A1 (TRPA1). Mol Pharmacol. 2008 Feb;73(2):274-81.

35. Frederick J, Buck ME, Matson DJ, Cortright DN. Increased TRPA1, TRPM8, and TRPV2 expression in dorsal root ganglia by nerve injury. Biochem Biophys Res Commun. 2007 Jul 13;358(4): 1058-64.

36. Ruparel NB, Patwardhan AM, Akopian AN, Hargreaves KM. Homologous and heterologous desensitization of capsaicin and mustard oil responses utilize different cellular pathways in nociceptors. Pain. 2008 Apr;135(3):271-9.
37. Numazaki M, Tominaga T, Takeuchi K, Murayama N, Toyooka H, Tominaga M. Structural determinant of TRPV1 desensitization interacts with calmodulin. Proc Natl Acad Sci U S A. 2003 Jun 24;100(13):8002-6.

38. Bhave G, Zhu W, Wang H, Brasier DJ, Oxford GS, Gereau RWt. cAMP-dependent protein kinase regulates desensitization of the capsaicin receptor (VR1) by direct phosphorylation. Neuron. 2002 Aug 15;35(4):721-31.

39. Banvolgyi A, Pozsgai G, Brain SD, Helyes ZS, Szolcsanyi J, Ghosh $\mathrm{M}$, et al. Mustard oil induces a transient receptor potential vanilloid 1 receptor-independent neurogenic inflammation and a non-neurogenic cellular inflammatory component in mice. Neuroscience. 2004;125(2):449-59.

40. Gamse R. Capsaicin and nociception in the rat and mouse. Possible role of substance P. Naunyn Schmiedebergs Arch Pharmacol. 1982 Sep;320(3):205-16.

41. Holzer P, Jurna I, Gamse R, Lembeck F. Nociceptive threshold after neonatal capsaicin treatment. Eur J Pharmacol. 1979 Oct 15;58 (4):511-4

42. Hayes AG, Scadding JW, Skingle M, Tyers MB. Effects of neonatal administration of capsaicin on nociceptive thresholds in the mouse and rat. J Pharm Pharmacol. 1981 Mar;33(3):183-5.

43. Cervero F, McRitchie HA. Neonatal capsaicin and thermal nociception: a paradox. Brain Res. 1981 Jun 29;215(1-2):414-8.

44. Neubert JK, Mannes AJ, Karai LJ, Jenkins AC, Zawatski L, AbuAsab M, et al. Perineural resiniferatoxin selectively inhibits inflammatory hyperalgesia. Mol Pain. 2008;4:3.

45. Davis JB, Gray J, Gunthorpe MJ, Hatcher JP, Davey PT, Overend P, et al. Vanilloid receptor-1 is essential for inflammatory thermal hyperalgesia. Nature. 2000 May 11;405(6783):183-7.

46. Obata K, Katsura H, Mizushima T, Yamanaka H, Kobayashi K, Dai $\mathrm{Y}$, et al. TRPA1 induced in sensory neurons contributes to cold hyperalgesia after inflammation and nerve injury. J Clin Invest. 2005 Sep;115(9):2393-401.

47. Katsura H, Obata K, Mizushima T, Yamanaka H, Kobayashi K, Dai Y, et al. Antisense knock down of TRPA1, but not TRPM8, alleviates cold hyperalgesia after spinal nerve ligation in rats. Exp Neurol. 2006 Jul;200(1):112-23.

48. Reid G, Babes A, Pluteanu F. A cold- and menthol-activated current in rat dorsal root ganglion neurones: properties and role in cold transduction. J Physiol. 2002 Dec 1;545(Pt 2):595-614.

49. Choi Y, Yoon YW, Na HS, Kim SH, Chung JM. Behavioral signs of ongoing pain and cold allodynia in a rat model of neuropathic pain. Pain. 1994 Dec;59(3):369-76.

50. Takahashi K, Sato J, Mizumura K. Responses of C-fiber low threshold mechanoreceptors and nociceptors to cold were facilitated in rats persistently inflamed and hypersensitive to cold. Neurosci Res. 2003 Dec;47(4):409-19.

51. Saade NE, Massaad CA, Ochoa-Chaar CI, Jabbur SJ, SafiehGarabedian B, Atweh SF. Upregulation of proinflammatory cytokines and nerve growth factor by intraplantar injection of capsaicin in rats. J Physiol. 2002 Nov 15;545(Pt 1):241-53.

52. Lessard N, Pare M, Lepore F, Lassonde M. Early-blind human subjects localize sound sources better than sighted subjects. Nature. 1998 Sep 17;395(6699):278-80. 
II. 


\title{
Divalent Heavy Metal Cations Block the TRPV1 $\mathrm{Ca}^{2+}$ Channel
}

\author{
László Pecze • Zoltán Winter • Katalin Jósvay • \\ Ferenc Ötvös • Csongor Kolozsi • Csaba Vizler • \\ Dénes Budai • Tamás Letoha • György Dombi • \\ Gerda Szakonyi • Zoltán Oláh
}

Received: 4 May 2012 / Accepted: 3 December 2012 /Published online: 21 December 2012

(C) The Author(s) 2012. This article is published with open access at Springerlink.com

\begin{abstract}
Transient receptor potential vanilloid 1 (TRPV1) is a non-selective cation channel involved in pain sensation and in a wide range of non-pain-related physiological and pathological conditions. The aim of the present study was to explore the effects of selected heavy metal cations on the function of TRPV1. The cations ranked in the following sequence of pore-blocking activity: $\mathrm{Co}^{2+}$ [half-maximal inhibitory concentration $\left.\left(\mathrm{IC}_{50}\right)=13 \mu \mathrm{M}\right]>\mathrm{Cd}^{2+}\left(\mathrm{IC}_{50}=\right.$ $38 \mu \mathrm{M})>\mathrm{Ni}^{2+}\left(\mathrm{IC}_{50}=62 \mu \mathrm{M}\right)>\mathrm{Cu}^{2+}\left(\mathrm{IC}_{50}=200 \mu \mathrm{M}\right) . \mathrm{Zn}^{2+}$ proved to be a weak $\left(\mathrm{IC}_{50}=27 \mu \mathrm{M}\right)$ and only partial inhibitor of the channel function, whereas $\mathrm{Mg}^{2+}, \mathrm{Mn}^{2+}$ and $\mathrm{La}^{3+}$ did not exhibit any substantial effect. $\mathrm{Co}^{2+}$, the most potent channel blocker, was able not only to compete with $\mathrm{Ca}^{2+}$ but also to pass with it through the open channel of TRPV1. In response to heat activation or vanilloid treatment, $\mathrm{Co}^{2+}$ accumulation was verified in TRPV1-transfected cell lines
\end{abstract}

Authors László Pecze and Zoltán Winter contributed equally to this work.

L. Pecze $\cdot$ Z. Winter $(\bowtie) \cdot$ K. Jósvay $\cdot$ C. Kolozsi $\cdot$ T. Letoha

G. Dombi $\cdot$ G. Szakonyi $\cdot$ Z. Oláh

Institute of Pharmaceutical Analysis, Faculty of Pharmacy,

University of Szeged, Szeged, Hungary

e-mail: winter.zoltan@brc.mta.hu

L. Pecze $\cdot$ K. Jósvay $\cdot$ F. Ötvös $\cdot$ C. Kolozsi $\cdot$ C. Vizler

Institute of Biochemistry, Biological Research Centre of the

Hungarian Academy of Sciences, Szeged, Hungary

D. Budai

Kation Europe, Szeged, Hungary

Z. Oláh

Acheuron Hungary Ltd., Szeged, Hungary

T. Letoha

Pharmacoidea Ltd., Szeged, Hungary

F. Ötvös

Greenformatix Nonprofit Ltd., Szeged, Hungary and in the TRPV1+ dorsal root ganglion neurons. The inhibitory effect was also demonstrated in vivo. $\mathrm{Co}^{2+}$ applied together with vanilloid agonists attenuated the nocifensive eye wipe response in mice. Different rat TRPV1 pore point mutants (Y627W, N628W, D646N and E651W) were created that can validate the binding site of previously used channel blockers in agonist-evoked ${ }^{45} \mathrm{Ca}^{2+}$ influx assays in cells expressing TRPV1. The $\mathrm{IC}_{50}$ of $\mathrm{Co}^{2+}$ on these point mutants were determined to be reasonably comparable to those on the wild type, which suggests that divalent cations passing through the TRPV1 channel use the same negatively charged amino acids as $\mathrm{Ca}^{2+}$.

Keywords Heavy metals - Somatosensory system · Pain · Calcium channel $\cdot$ TRPV1 $\cdot$ Cobalt

\section{Introduction}

Small-diameter sensory neurons in the peripheral nervous system (PNS) express the transient receptor potential/vanilloid receptor subtype 1 (TRPV1). Four identical subunits of this protein form a functional $\mathrm{Ca}^{2+}$ channel. Similarly to other transient receptor potential channel members, the TRPV1 channel belongs in the large superfamily of cation channels with six transmembrane (TM) segments. Following agonistinduced channel opening, a pore loop between segments TM5 and TM6 serves as a cation filter and entry site [1].

When endovanilloids are produced under various inflammatory conditions around the $\mathrm{C}$ and $\mathrm{A} \delta$ afferents of these PNS neurons, TRPV1 transmits a specific pain sensation to the brain [2-4]. Besides endovanilloids such as anandamide $[5,6]$, TRPV1 is activated by acids $(\mathrm{pH}<6.3)$ and chemoirritants such as the exovanilloid capsaicin (CAPS) or resiniferatoxin, a naturally occurring, ultrapotent CAPS analogue with excellent specificity for TRPV1 [2, 7-9]. Moreover, 
TRPV1 can integrate the effects of heat and vanilloids. The heat-sensing domain has been mapped to the C-terminal intracellular region $[3,9,10]$.

The vanilloid binding site is localized between segments TM3 and TM4 of TRPV1 [5]. The pain signal, however, is generated by opening of the $\mathrm{Ca}^{2+}$ channel situated between domains TM5 and TM6 of four identical subunits $[11,12]$. An acidic peptide motif in the pore loop region of TRPV1 $(D X E X X E X X D)$ may serve as a docking site for positively charged ions and channel blockers [13]. However, our sequence comparison and previous in silico modelbuilding efforts have not revealed any obvious homology to other divalent metal ion $\left(\mathrm{M}^{2+}\right)$-binding structures such as the EF-hand (DXDXDGXXDXXE) or the Excalibur (DXDXDXXXCE) [13].

Various studies have demonstrated that positively charged molecules can act as TRPV1 receptor channel blockers by plugging the pore. Ruthenium Red (RuRed) (a well-known, but non-specific TRPV1 pore blocker) [11], $\mathrm{R}_{4} \mathrm{~W}_{2}$ (a positively charged hexapeptide) [14] and anti-calmodulins/antipsychotic tricyclics [13] have been shown to be able to bind to the DXEXXEXXD domain of TRPV1, whereby they block the movement of $\mathrm{Ca}^{2+}$ through the pore region.

We set out to assess the effects of various metal cations at different concentrations on the vanilloid -or heat-induced activity of the TRPV1 channel, focusing on the investigation of the most potent cations in vitro and in vivo. Moreover, in our experiments we aimed to shed light on the characteristics of the gating of the TRPV1 channel in order to improve the understanding of the structure and function of the TRPV1 pore region, which may lead to the development of potentially useful painkiller drugs that modulate the activity of this receptor.

\section{Materials and Methods}

Reagents Stock solutions (200 mM) of $\mathrm{CoCl}_{2}, \mathrm{NiCl}_{2}, \mathrm{ZnSO}_{4}$, $\mathrm{CdCl}_{2}, \mathrm{CuSO}_{4}, \mathrm{CaCl}_{2}, \mathrm{CoCl}_{2}$ and $\mathrm{LaCl}_{3}$ were dissolved in water and diluted as required to the working concentrations. To avoid the precipitation of insoluble $\mathrm{La}(\mathrm{OH})_{3}$ and $\mathrm{La}$ $\left(\mathrm{CO}_{3}\right)_{3}$, the formation of radiocolloids and the loss of $\mathrm{La}^{3+}$ by adsorption to container surfaces, $\mathrm{LaCl}_{3}$ solution was prepared fresh daily in polyethylene vials [15]. RuRed and capsazepine (CapZ; Sigma-Aldrich, St. Louis, MO) were dissolved in DMSO. CAPS was dissolved initially as a stock solution of $3 \mathrm{mM}$ in $95 \%$ ethanol. The peptide $\mathrm{R}_{4} \mathrm{~W}_{2}$ was synthetized in our laboratories and then dissolved in water and used as a $25 \mathrm{mM}$ stock solution. Amitriptyline (AMI), purchased from Sigma-Aldrich, was dissolved in water.

Plasmids The C-terminally epsilon-tagged rat TRPV1 $\varepsilon$ plasmid construct was prepared in the metallothionein
(pMTH) plasmid vector as described earlier [9]. To avoid cell loss through the $\mathrm{Ca}^{2+}$-excytotoxic mechanism that occurs when TRPV1 is overexpressed at $37{ }^{\circ} \mathrm{C}$, only the basal activity of the pMTH promoter was used. The protein kinase $\mathrm{C} \varepsilon$ epitope tag allowed immunological detection of the TRPV1 $\varepsilon$ protein, as earlier described [16]. Mutants Y627W, N628W, D646N and E651W were kindly given by Dr. K. J. Swartz (National Institutes of Health, Bethesda, MD 20892, USA) [17] and subcloned into an EF-promoterdriven green fluorescent protein (EGFP)-tagging plasmid vector. The EGFP tag was used for visual determination of the transfection rate by flow cytofluorometry with a FACSCalibur instrument (Becton Dickinson, San Jose, CA, USA).

Cell Lines Expressing TRPVI Ectopically The HaCaT keratinocyte cell line was a kind gift of Prof. B. Farkas (Department of Dermatology, University of Cologne, Federal Republic of Germany) [18]. The COS-7 (CRL-1651) and BALB/c-3T3 (CCL-163) cell lines were obtained from ATCC. The 3T3 and HaCaT cell lines permanently expressing the rat TRPV1 channel were prepared as described earlier [19]. COS7 cells were transiently transfected with plasmid containing the sequence of the Y627W, N628W, D646N or E651W TRPV1 mutants or the wild-type TRPV1 channel, by using the Fugene transfection reagent (Roche, Mannheim, Germany). The transfection efficacy was determined by flow cytofluorometry.

Primary Dorsal Root Ganglion Cultures Were prepared from E16 embryonic rats as reported earlier [9]. Briefly, dorsal root ganglions (DRGs) were dissected and then processed in Hank's balanced salt buffer until plated in Dulbecco's Modified Eagle Medium (DMEM). The DMEM contained $20 \mathrm{mM}$ HEPES, $\mathrm{pH} 7.4,7.5 \%$ foetal bovine serum, $7.5 \%$ horse serum, $5 \mathrm{mg} / \mathrm{ml}$ uridine supplemented with $2 \mathrm{mg} / \mathrm{ml}$ 5-fluoro-2'-deoxyuridine and $40 \mathrm{ng} / \mathrm{ml}$ nerve growth factor to inhibit cell division and to promote the differentiation of long neuronal processes, respectively. Cells were seeded on $25 \mathrm{~mm}$ glass coverslips.

Cobalt Histochemistry Rat DRG cells attached to the coverslips were washed in buffer A (in millimolars: $\mathrm{NaCl}, 57.5$; $\mathrm{KCl}, 5 ; \mathrm{MgCl}_{2}, 2$; HEPES, 10; glucose, 12; sucrose, 139; $\mathrm{pH}$ 7.4) for $2 \mathrm{~min}$, and then incubated at $37^{\circ} \mathrm{C}$ for $10 \mathrm{~min}$ in $\mathrm{Co}^{2+}$-uptake solution (buffer $\mathrm{A}+5 \mathrm{mM} \mathrm{CoCl} 2$ ) containing $20 \mu \mathrm{M}$ CAPS. High $(20 \mu \mathrm{M})$ capsaicin concentration is used in order to obtain a robust and easily detectable $\mathrm{Co}^{2+}$ signal. Following a brief wash in buffer $\mathrm{A}$, the water-soluble $\mathrm{Co}^{2+}$ taken up by the cells was precipitated with $0.12 \%$ ammonium polysulphide (Sigma-Aldrich) in buffer A, which resulted in the formation of dark, water-insoluble CoS in TRPV $1+$ cells. Cells were fixed in $4 \%$ formaldehyde and mounted on glass slides, using Kaiser's glycerol 
gelatine (Merck, Darmstadt, FRG). Cells were examined under a Nikon light microscope (Melville, NY, USA) and photographed with a SPOT RT-SETM Digital Camera (Diagnostic Instruments). Pictures of the cells were analysed by means of ImageJ $1.45 \mathrm{~s}$ software (National Institutes of Health, USA), and the subsequent statistical analyses were performed with PRISM ${ }^{\mathrm{TM}} 3.01$ software (GraphPad Software, Inc. San Diego, CA, USA).

Vanilloid-Induced ${ }^{45} \mathrm{Ca}^{2+}$ Uptake Vanilloid-induced ${ }^{45} \mathrm{Ca}^{2+}$ transport was assayed in the $\mathrm{HaCaT}$ adherent cell lines ectopically expressing the $\mathrm{C}$-terminally $\varepsilon$-tagged rat TRPV1 $\left(3 \times 10^{4}\right.$ cells/well $)$ and Cos 7 cells transiently transfected with rat TRPV1 mutants, seeded in poly-D lysine-coated 96-well plates. Immediately before the transport assay, the cells were washed three times with physiological saline solution at room temperature $\left(20-25^{\circ} \mathrm{C}\right)$. We had previously found that TRPV1-transformed cells functioned in the same manner at room temperature as at $30{ }^{\circ} \mathrm{C}$ (data not shown). ${ }^{45} \mathrm{Ca}^{2+}$ uptake was performed for 10 min with $0.1 \mu \mathrm{Ci}^{45} \mathrm{Ca}^{2+}$ as radioactive tracer in a final volume of $100 \mu \mathrm{l}(1.8 \mu \mathrm{M})$. CAPS was diluted from a $3 \mathrm{mM}$ ethanol stock solution to the indicated final concentrations. For the termination of ${ }^{45} \mathrm{Ca}^{2+}$ uptake, cells were rapidly washed four additional times with $0.2 \mathrm{ml}$ PBS solution, and then lysed in $80 \mu \mathrm{l} / \mathrm{well}$ RIPA buffer $(50 \mathrm{mM}$ Tris-HCl, $\mathrm{pH} 7.5,150 \mathrm{mM} \mathrm{NaCl}, 1 \%$ Triton X-100, $0.5 \%$ deoxycholate, $0.1 \%$ SDS and $5 \mathrm{mM}$ EDTA) for $30 \mathrm{~min}[8,9$, $20,21]$. Aliquots of the solubilised cell extracts were mixed with $120 \mu \mathrm{l}$ SuperMiX and counted in a 96-well plate liquid scintillation counter (TopCount-NXT, Packard). To measure the effect of temperature on the TRPV1 function in the ${ }^{45} \mathrm{Ca}^{2+}$ uptake assay, TRPV1/HaCaT cells were plated on six-well plates. ${ }^{45} \mathrm{Ca}^{2+}$ uptake was evoked with $10 \mathrm{ml}$ preheated buffer. The procedure was followed as described above.

After the measurement, the data were corrected for the basal activity of TRPV1 and normalized from zero to one, where zero denotes the counts per minute in TRPV1/HaCaT cells without CAPS and one denotes the counts per minute in TRPV1/HaCaT cells with CAPS. The results of three parallel measurements were averaged and evaluated with PRISM $^{\text {TM }} 3.01$ software (GraphPad Software, Inc. San Diego, CA, USA). During curve fitting, the "Analyze/Nonlinear regression (curve fit)/Sigmoidal dose-response" menu of PRISM ${ }^{\mathrm{TM}}$ software was applied. The curve-fitting equation was: $Y=Y_{\min }+\left(Y_{\max }-Y_{\min }\right) /\left(1+10^{(\log \mathrm{EC} 50-\mathrm{X})}\right)$, where $X=$ logarithm of concentration and $Y=$ the response.

Eye Wipe Tests Eye wipe tests were performed on CD1 mice. A $100 \mu \mathrm{M}$ CAPS solution, or a solution containing $100 \mu \mathrm{M}$ CAPS and $1 \mathrm{mM} \mathrm{CoCl}_{2}$, or a solution containing $100 \mu \mathrm{M}$ CAPS and $5 \mu \mathrm{M} \mathrm{CapZ}$ was dropped into the eye, and the number of defensive wiping movements was then counted.
Statistical Analysis One-way ANOVA followed by Turkey's post-tests was performed with GraphPad Prism version 3.01 software (GraphPad Software, Inc. San Diego, CA, USA).

\section{Results}

In the ${ }^{45} \mathrm{Ca}^{2+}$ uptake assay, the $\mathrm{EC}_{50}$ of CAPS for wild-type TRPV1 was determined to be $0.0860 \mu \mathrm{M}$. Approximately $1 \mu \mathrm{M}$ CAPS caused the full activation $\left(\mathrm{EC}_{100}\right)$ of TRPV1 at $\mathrm{pH}$ 7.5. Channel blocker-screening assays were therefore carried out with $2 \mu \mathrm{M}$ CAPS (an excess amount of agonist), which does not cause $\mathrm{Ca}^{2+}$ cytotoxicity during the 10-min incubation period. The interactions of the metal ions with TRPV1 were studied by using a vanilloid-induced ${ }^{45} \mathrm{Ca}^{2+}$ uptake assay. Experiments were carried out on the TRPV1/ $\mathrm{HaCaT}$ permanent indicator cell line. Channel opening was induced by CAPS in the presence of progressively increasing $\mathrm{M}^{2+}$ concentrations in the uptake solution. Incubation of the cells in uptake solutions containing both ${ }^{45} \mathrm{Ca}^{2+}$ and $\mathrm{Mg}^{2+}, \mathrm{Mn}^{2+}$ or $\mathrm{La}^{3+}$ (data not shown) resulted in little or no effect, even at the highest concentration $(4 \mathrm{mM})$, whereas $\mathrm{Zn}^{2+}$ proved to be a weak [half-maximal inhibitory concentrations $\left.\left(\mathrm{IC}_{50}\right)=27 \mu \mathrm{M}\right]$ and only partial inhibitor of the $2 \mu \mathrm{M}$ CAPS-induced ${ }^{45} \mathrm{Ca}^{2+}$ uptake. The other cations effectively blocked the vanilloid-induced $\mathrm{Ca}^{2+}$ entry into TRPV1/HaCaT cells, with the following sequence of potency: $\mathrm{Co}^{2+}\left(\mathrm{IC}_{50}=13 \mu \mathrm{M}\right)>\mathrm{Cd}^{2+}\left(\mathrm{IC}_{50}=38 \mu \mathrm{M}\right)>$ $\mathrm{Ni}^{2+}\left(\mathrm{IC}_{50}=62 \mu \mathrm{M}\right)>\mathrm{Cu}^{2+}\left(\mathrm{IC}_{50}=200 \mu \mathrm{M}\right.$; Fig. 1a).

To assess the effect of $\mathrm{Co}^{2+}$, the most potent TRPV1 inhibitor, on the heat-activated TRPV1 channels, the activity of TRPV1 was investigated in the presence either of $2 \mu \mathrm{M}$ CAPS alone or of $2 \mu \mathrm{M} \mathrm{CAPS}+250 \mu \mathrm{M} \mathrm{Co}^{2+}$, at both 37 and $42{ }^{\circ} \mathrm{C}$. The negative control did not contain CAPS. In this assay, high temperature activated the TRPV1 channels and also increased the CAPS-evoked ${ }^{45} \mathrm{Ca}^{2+}$ influx. $\mathrm{Co}^{2+}$ reduced both the heat and CAPS-induced ${ }^{45} \mathrm{Ca}^{2+}$ influx (Fig. 1b).

To compare the potency of $\mathrm{Co}^{2+}$ with those of the other positively charged channel blockers, we measured the $\mathrm{IC}_{50}$ values of RuRed, $A M I$ and $\mathrm{R}_{4} \mathrm{~W}_{2}$, which are known to have a docking site in the pore loop of TRPV1. The inhibitor potentials of these pore blockers were measured via the CAPS-induced ${ }^{45} \mathrm{Ca}^{2+}$ uptake. All of them inhibited CAPS-activated TRPV1, with the following $\mathrm{IC}_{50}$ values: RuRed $=1 \mu \mathrm{M}, \mathrm{AMI}=20 \mu \mathrm{M}$ and $\mathrm{R}_{4} \mathrm{~W}_{2}=100 \mu \mathrm{M}$ (Fig. 1c).

For a better understanding of the inhibition kinetics of $\mathrm{Co}^{2+}$ on TRPV1, increasing concentrations of both $\mathrm{Co}^{2+}$ and CAPS were applied in the vanilloid-induced ${ }^{45} \mathrm{Ca}^{2+}$-uptake assays. The $\mathrm{Ca}^{2+}$ uptake of TRPV1/HaCaT cells was inhibited by the simultaneous presence of $\mathrm{Co}^{2+}$ in a dosedependent manner. However, increasing concentrations of $\mathrm{Co}^{2+}$ decreased only the maximal response of efficacy 

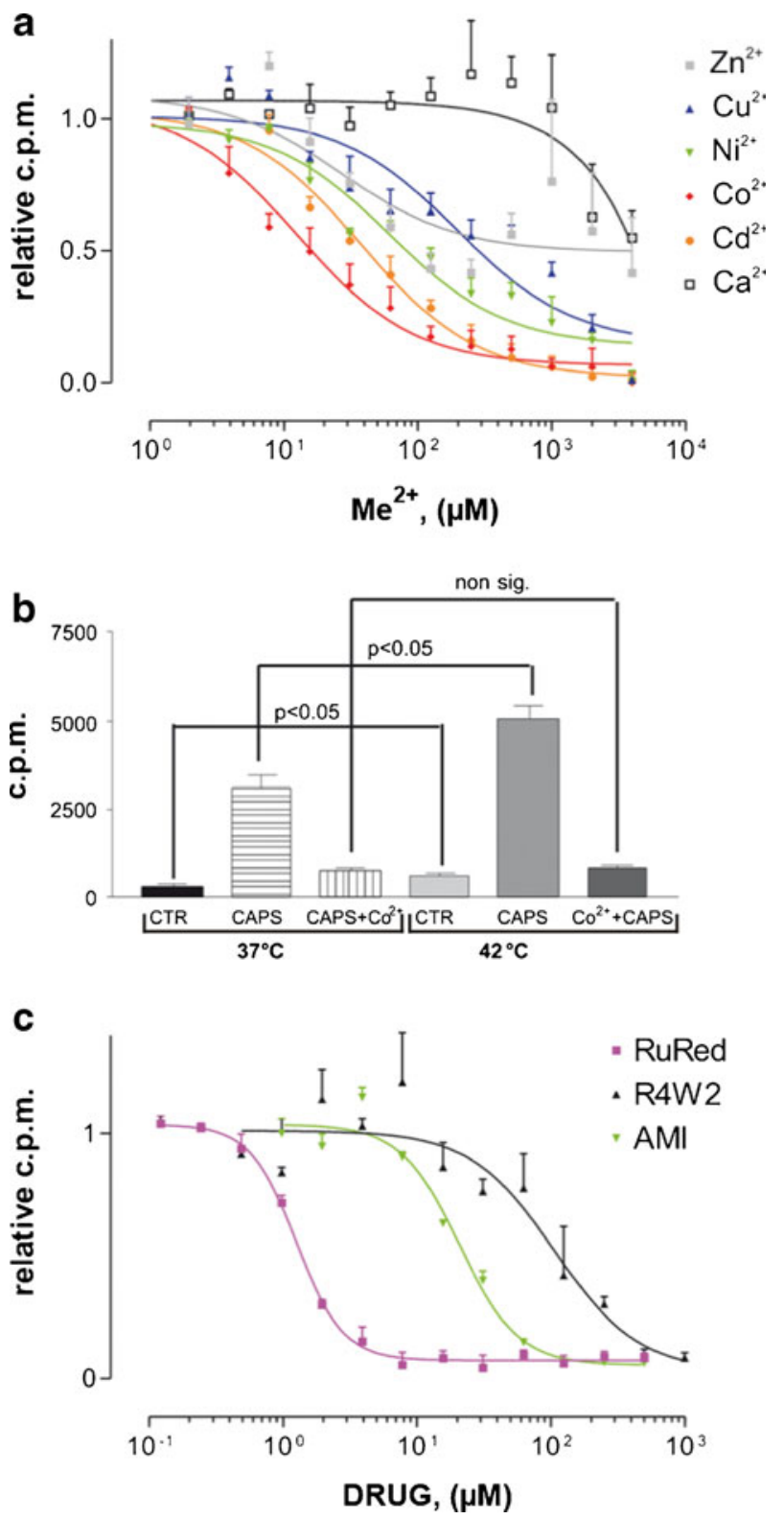

Fig. 1 Ranking divalent cations as channel blockers in cell-based assays. a Efficacy of $\mathrm{M}^{2+}$ inhibitors of TRPV1 ranked by vanilloidinduced ${ }^{45} \mathrm{Ca}^{2+}$ uptake. b $\mathrm{Co}^{2+}$ inhibits heat-induced $\mathrm{Ca}^{2+}$ uptake at $37{ }^{\circ} \mathrm{C}$ and at $42{ }^{\circ} \mathrm{C}$. c RuRed, $\mathrm{R}_{4} \mathrm{~W}_{2}$ and AMI, previously validated selective channel blockers of TRPV1, were also tested for better comparison of inhibitors. Data are mean values \pm standard deviation (SD) of the results of three independent experiments. Statistical significance was assessed by post hoc LSD $t$ tests after significant one-way analysis of variance (ANOVA). $P<0.05$

$\left(E_{\max }\right)$ of $\mathrm{Ca}^{2+}$ entry; the affinity of CAPS for TRPV1 did not change. The inflection point in the CAPS dose-response curves in each of the $\mathrm{Co}^{2+}$ co-incubation studies was found at $\sim 0.08 \mu \mathrm{M}$ (i.e. $\mathrm{EC}_{50}$ ), independently of the $\mathrm{Co}^{2+}$ concentration. The $\mathrm{Co}^{2+}$ inhibition patterns unequivocally indicated channel blocking kinetics (Fig. 2a).

By varying the concentrations of $\mathrm{Co}^{2+}$ and $\mathrm{Ca}^{2+}$ and measuring the radioactive ${ }^{45} \mathrm{Ca}^{2+}$ influx, we assessed whether there was a competition between $\mathrm{Co}^{2+}$ and $\mathrm{Ca}^{2+}$. The effect of dilution on the amount of accumulated ${ }^{45} \mathrm{Ca}^{2+}$ did not appear at extracellular cold $\mathrm{Ca}^{2+}$ concentrations below $1 \mathrm{mM}$ (Fig. 1a), indicating that TRPV1+ cells accumulate $\mathrm{Ca}^{2+}$ very effectively from the extracellular space and collect them putatively into ER or mitochondria. Increasing cold $\mathrm{Ca}^{2+}$ concentration decreased the inhibitory effect of $\mathrm{Co}^{2+}\left(\mathrm{IC}_{50}\right.$ values in the presence of $0,15.625,31.25,62.5$ and $125 \mu \mathrm{M}$ cold $\mathrm{Ca}^{2+}: 7.944,51.22,72.69,79.09$ and $189.1 \mu \mathrm{M}$, respectively), showing that the effect of $\mathrm{Co}^{2+}$ on $\mathrm{Ca}^{2+}$ entry mainly depends on the competition for entry sites. These results suggest that the $\mathrm{Co}^{2+}$ entry through the TRPV1 channel is slower, and the $\mathrm{Co}^{2+}$ displacing the $\mathrm{Ca}^{2+}$ from the pore region of TRPV1 slows down or inhibits the $\mathrm{Ca}^{2+}$ uptake (Fig. 2b).

The prolonged agonist stimulation of TRPV1 has been reported to result in an increased permeability to larger cations [22] or small molecules [23], due to conformational changes in the open state of the TRPV1. Thus, we analysed the kinetics of the channel-blocking activity of $\mathrm{Co}^{2+}$ by employing different CAPS concentrations. An anticipated shift in the $\mathrm{IC}_{50}$ of $\mathrm{Co}^{2+}$ would be evidence supporting the idea that $\mathrm{Co}^{2+}$ entry depends on the TRPV1 open stages. We indeed observed a shift in the $\mathrm{IC}_{50}$ of $\mathrm{Co}^{2+}$, which decreased with increasing CAPS concentration (Fig. 2c). Consequently, increasing agonist concentration enhances the blocking ability of $\mathrm{Co}^{2+}$. To investigate this phenomenon, we plotted the $\mathrm{IC}_{50}$ values as a function of CAPS concentration. Curvefitting analysis confirmed a strong interrelationship between $\mathrm{IC}_{50}$ and the CAPS dose applied (Fig. 2d), suggesting that the increased efficiency of inhibition correlates with the different open-state conformations of the TRPV1 channel.

We traced $\mathrm{Co}^{2+}$ upon vanilloid induction in sensory neuron cultures prepared from DRGs of rat embryos. To test $\mathrm{Co}^{2+}$-accumulation patterns, cells were co-incubated with $20 \mu \mathrm{M}$ CAPS in $\mathrm{Co}^{2+}$-containing $\mathrm{Ca}^{2+}$-uptake medium, and the $\mathrm{Co}^{2+}$ was then localized by means of $\mathrm{NH}_{4} \mathrm{~S}$ histochemistry. These experiments revealed that $\mathrm{Co}^{2+}$ not only competes with $\mathrm{Ca}^{2+}$ but also enters into the cytosol of specific PNS sensory neurons. Functionally responsive vanilloid-sensitive neurons (i.e. TRPV $1^{+}$) exhibited darkbrown $\mathrm{Co}^{2+}$ precipitates inside the rounded neuronal bodies (Fig. 3e). As expected from previous studies, TRPV1 is endogenously expressed in approximately one third of the cultured neurons [24-27]. Without CAPS, no intracellular $\mathrm{Co}^{2+}$ accumulation was observed (data not shown). Similar experiments were carried out on rTRPV1/HaCaT and rTRPV1/3T3 cell lines. The accumulation of $\mathrm{Co}^{2+}$ was blocked by RuRed, a channel blocker of heat and vanilloid pain signalling. Moreover, the dose-dependent inhibition of the cellular entry of $\mathrm{Co}^{2+}$ was determined by the coapplication of $5 \mu \mathrm{M} \mathrm{CapZ,} \mathrm{a} \mathrm{long-known} \mathrm{competitive}$ 
a
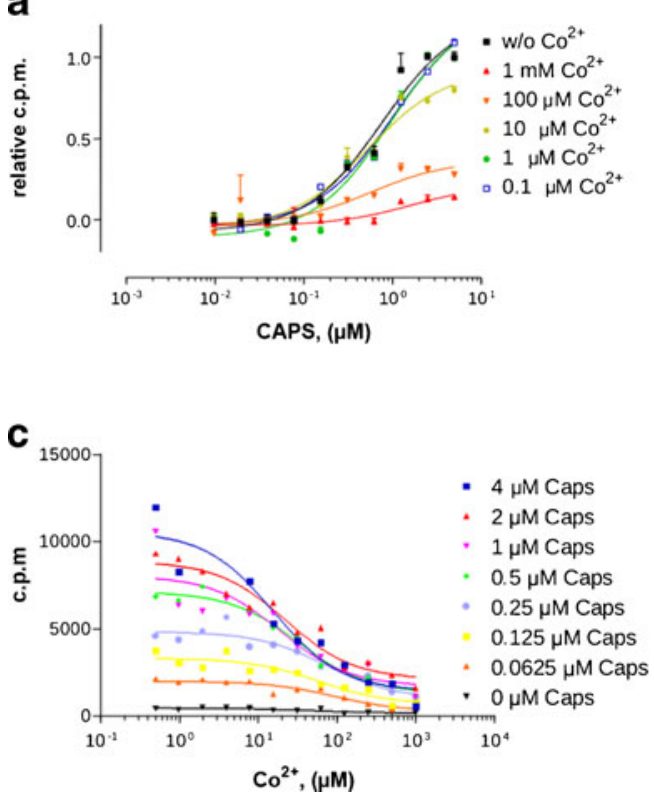

b
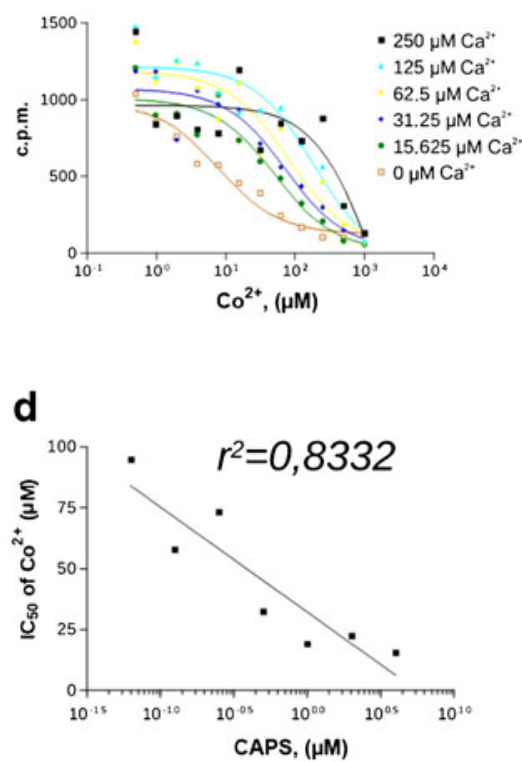

Fig. $2 \mathrm{Co}^{2+}$ inhibits $\mathrm{Ca}^{2+}$ entry through the TRPV1 channel. a Kinetics of inhibition of $\mathrm{Ca}^{2+}$ transport by $\mathrm{Co}^{2+}$ in TRPV1+ cells. Data are mean values $\pm \mathrm{SD}$ of the results of three independent experiments. b Kinetics of competition between $\mathrm{Co}^{2+}$ and cold $\mathrm{Ca}^{2+}$ in TRPV1+ cells. $\mathrm{c} \mathrm{Co}^{2+}$ blockage at different CAPS concentrations. Representative data

antagonist of pungent vanilloids. After analysis of the photographs of the cells with the ImageJ program, statistical analysis of the data further confirmed our findings: the mean gray values of CAPS-exposed, CAPS-free and CapZexposed cells proved to be significantly different (CAPS without $\mathrm{Co}^{2+}, 72.05 \pm 12.38$ (S.D.), $n=146$; $\mathrm{CAPS}+\mathrm{Co}^{2+}$, $124.4 \pm 21.51$ (S.D.), $n=111$; CAPS $+\mathrm{Co}^{2+}+\mathrm{CapZ}, 76.92 \pm$ 22.21 (S.D.), $n=100 ; P$ values of the $t$ tests: CAPS without $\mathrm{Co}^{2+}$ vs. CAPS $+\mathrm{Co}^{2+}, P<0.0001 ; \mathrm{CAPS}+\mathrm{Co}^{2+}$ vs. CAPS + $\mathrm{Co}^{2+}+\mathrm{CapZ}, P<0.0001$; CAPS without $\mathrm{Co}^{2+}$ vs. CAPS + $\mathrm{Co}^{2+}+$ CapZ, $P=0.0290$; Fig. 3). The gray values were measured on the negatives of the images: the darker the cells, the higher the gray values. Analysis of the pictures in Fig. 4, showing TRPV1-expressing HaCaT cells, resulted in the same outcome. Following ANOVA, the groups were compared by using $t$ tests. Each $t$ test except that involving CAPS without $\mathrm{Co}^{2+}$ vs. CAPS $+\mathrm{Co}^{2+}+100 \mu \mathrm{M} \mathrm{CapZ}$ indicated a significant difference between the pairs of groups $(P<0.05$; Fig. 4). No substantial staining could be observed on $3 \mathrm{~T} 3$ cells (Fig. 5a-e). Statistical analysis of the gray values of the cells indicated no significant darkening in the absence of TRPV1 in the cell membrane.

In order to rule out the possibility that $\mathrm{Co}^{2+}$ can enter the cells through VGCCs, 3T3 cells were challenged with $50 \mathrm{mM}$ extracellular $\mathrm{KCl}$. These cells did not show any VGCC activity: the high extracellular $\mathrm{KCl}$ concentrationinduced depolarization that opens the VGCC channels did not cause ${ }^{45} \mathrm{Ca}^{2+}$ accumulation in the ${ }^{45} \mathrm{Ca}^{2+}$-uptake assay. are shown from independent experiments repeated at least three times. d $\mathrm{IC}_{50}$ values as a function of CAPS concentrations. $\mathrm{IC}_{50}$ values of $\mathrm{Co}^{2+}$ in the presence of $0.0625,0.125,0.25,0.5,1,2$ or $4 \mu \mathrm{M}$ CAPS are 94.81, $57.97,73.17,32.6,19.22,22.55$ and $15.62 \mu \mathrm{M}$, respectively

Moreover, the VGCC blocker nisoldipine did not decrease the CAPS-induced TRPV1-mediated ${ }^{45} \mathrm{Ca}^{2+}$ accumulation (data not shown). $\mathrm{No} \mathrm{Co}^{2+}$ staining was observed in the presence of $50 \mathrm{mM}$ extracellular $\mathrm{KCl}$ (Fig. $5 \mathrm{f}-\mathrm{j}$ ). ANOVA indicated no significant differences among the groups $(P=0.9150)$. These results confirm that the CAPSinduced $\mathrm{Ca}^{2+}$ and $\mathrm{Co}^{2+}$ influx in TRPV1/3T3 cells is due exclusively to the TRPV1 channel activity.

Besides the in vitro demonstration of $\mathrm{Co}^{2+}$ antagonism, we further validated this $\mathrm{Co}^{2+}$ inhibition phenomenon in tests of eye wiping in response to pungent vanilloids [28]. $\mathrm{Co}^{2+}$ again decreased the frequency of vanilloid-evoked defending movements. Inhibition experiments with CapZ cross-validated and confirmed our earlier findings (Fig. 6a).

To validate that $\mathrm{Co}^{2+}$ inhibition is a consequence of competition with $\mathrm{Ca}^{2+}$ for $\mathrm{M}^{2+}$-chelating sites in the pore loop domain, we prepared several point mutants in this region of TRPV1, and determined the channel kinetics through ${ }^{45} \mathrm{Ca}^{2+}$ uptake experiments in 3T3 cells expressing the mutant channels. Some of these mutants had been partially characterized earlier in the context of spider venom channel inhibitors [17], and these residues proved to have an important role in the binding of various previously tested channel blockers (RuRed, etc.). Mutated sites are illustrated schematically in Fig. 6b. The $\mathrm{EC}_{50}$ and $\mathrm{EC}_{100}$ values of mutant channels for CAPS were different from those of the wild type $\left(\mathrm{D} 646 \mathrm{~N} \mathrm{EC}_{50}=\right.$ $270 \mathrm{nM}, \mathrm{E} 651 \mathrm{~W} \mathrm{EC}{ }_{50}=540 \mathrm{nM}, \mathrm{N} 628 \mathrm{~W} \mathrm{EC}_{50}=720 \mathrm{nM}$ and $\mathrm{Y} 627 \mathrm{~W} \mathrm{EC} \mathrm{E}_{50}=820 \mathrm{nM}$ ), and the blocking effects of $\mathrm{Co}^{2+}$ and 

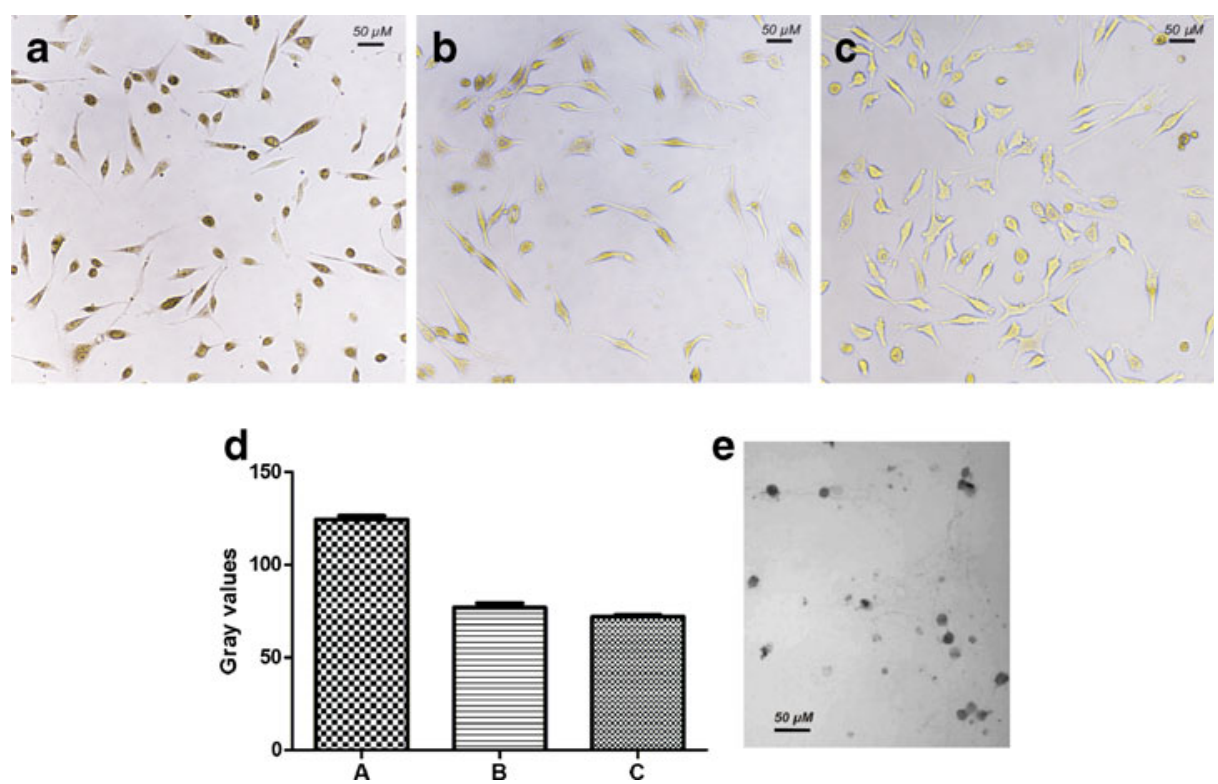

Fig. $3 \mathrm{Co}^{2+}$ histochemistry on the $3 \mathrm{~T} 3$ cell line expressing TRPV1 ectopically. Cells were incubated for $10 \mathrm{~min}$ in buffer A containing a $20 \mu \mathrm{M}$ CAPS $+5 \mathrm{mM} \mathrm{Co}^{2+} ;$ b $20 \mu \mathrm{M}$ CAPS $+5 \mathrm{mM} \mathrm{Co}^{2+}+5 \mu \mathrm{M}$ CapZ; c $5 \mathrm{mM} \mathrm{Co}^{2+}$ without CAPS. The dark $\mathrm{CoS}$ precipitate indicates the presence of intracellular $\mathrm{Co}^{2+}$ that is blockable with $\mathrm{CapZ}$, a competitive antagonist of pungent vanilloids. d Gray values of the 3 T3 cell line expressing TRPV1 measured by means of ImageJ software. $\mathrm{C}^{2+}$ histochemistry in CAPS-sensitive rat DRG neurons. Scale bar $=0.05 \mathrm{~mm}$. These results confirm that $\mathrm{Co}^{2+}$ not only acts as a blocker but also enters the cell with $\mathrm{Ca}^{2+}$ through the TRPV1 channel
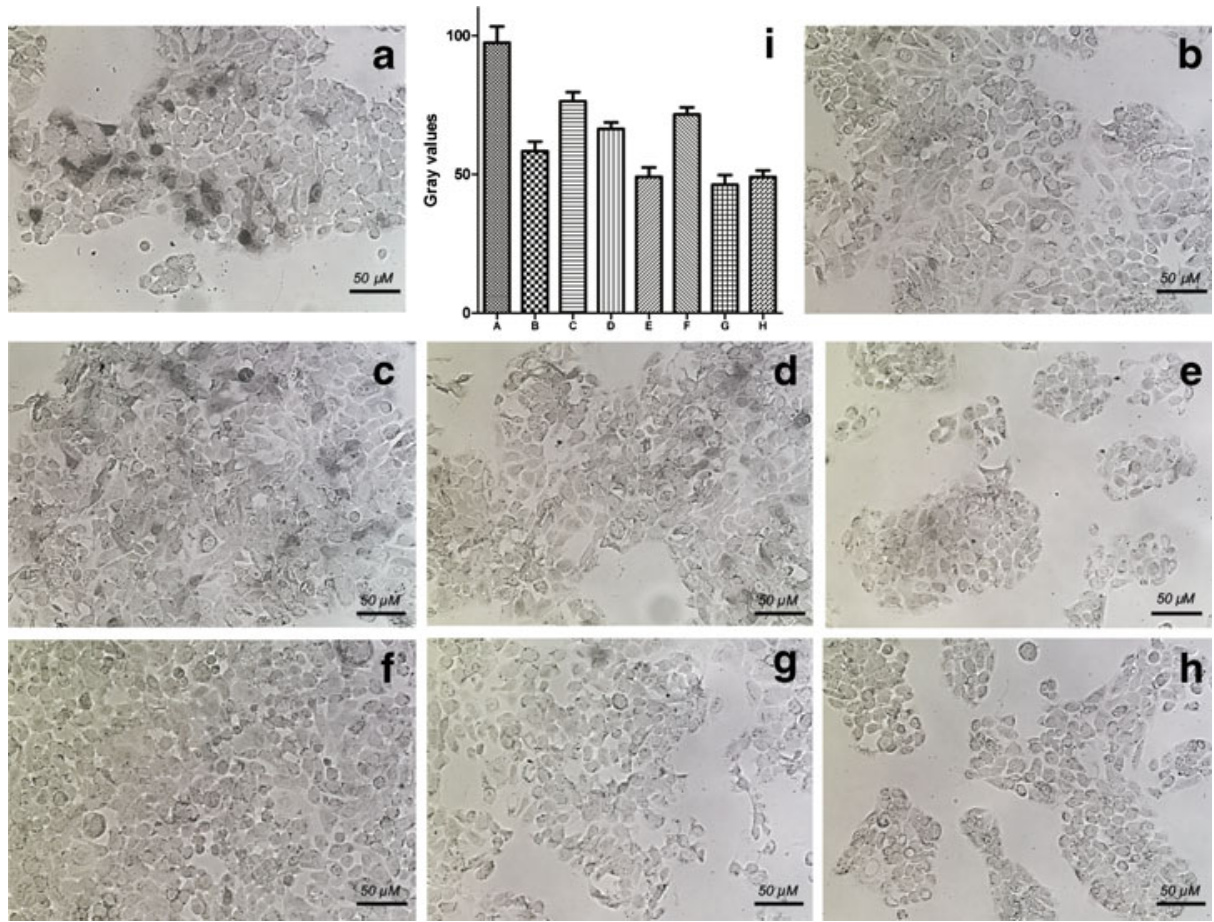

Fig. $4 \mathrm{Co}^{2+}$ histochemistry on the HaCaT cell line expressing TRPV1 ectopically. Cells were incubated for $10 \mathrm{~min}$ in buffer A containing a $20 \mu \mathrm{M} \mathrm{CAPS}+5 \mathrm{mM} \mathrm{Co}^{2+} ; \mathbf{b} 5 \mathrm{mM} \mathrm{Co}^{2+}$ without CAPS; $\mathbf{c} 20 \mu \mathrm{M}$ CAPS $+5 \mathrm{mM} \mathrm{Co}^{2+}+300 \mathrm{nM} \mathrm{CapZ} ; \mathbf{d} 20 \mu \mathrm{M} \mathrm{CAPS}+5 \mathrm{mM} \mathrm{Co}^{2+}+5 \mu \mathrm{M} \mathrm{CapZ}$; e $20 \mu \mathrm{M}$ CAPS $+5 \mathrm{mM} \mathrm{Co}^{2+}+100 \mu \mathrm{M} \mathrm{CapZ}$; f $20 \mu \mathrm{M} \mathrm{CAPS}+5 \mathrm{mM}$ $\mathrm{Co}^{2+}+500 \mathrm{nM}$ RuRed; g $20 \mu \mathrm{M}$ CAPS $+5 \mathrm{mM} \mathrm{Co}{ }^{2+}+7 \mu \mathrm{M}$ RuRed; h $20 \mu \mathrm{M}$ CAPS $+5 \mathrm{mM} \mathrm{Co}{ }^{2+}+100 \mu \mathrm{M}$ RuRed. The dark precipitates indicate the presence of intracellular $\operatorname{CoS}$ that is blockable with RuRed, a channel blocker of heat and vanilloid pain signalling. Co-application of CapZ, a competitive antagonist of pungent vanilloids, also inhibited the cellular entry of $\mathrm{Co}^{2+}$ in a dose-dependent manner: this is a wellcharacterized evidence-based method of localization of intracellular $\mathrm{Co}^{2+}$. I: Gray values of the HaCaT cell line expressing TRPV1 measured by means of Image J software 
Fig. $5 \mathrm{Co}^{2+}$ histochemistry on the 3 T3 cell line. Cells were incubated for $10 \mathrm{~min}$ in buffer A containing: a $20 \mu \mathrm{M}$ $\mathrm{CAPS}+5 \mathrm{mM} \mathrm{Co}^{2+}+5 \mu \mathrm{M}$ CapZ; c $5 \mathrm{mM} \mathrm{Co}^{2+}$ without CAPS. d $20 \mu \mathrm{M}$ CAPS without $\mathrm{Co}^{2+}$. No CoS precipitate could be observed in the absence of TRPV1 protein in the cell membrane. e Gray values of the 3T3 cell line measured by means of Image J software. Cells were incubated for $10 \mathrm{~min}$ in: $\mathbf{f}$ buffer A containing $5 \mathrm{mM}$ $\mathrm{Co}^{2+} ; \mathbf{g}$ buffer A without $\mathrm{Co}^{2+}$; $\mathbf{h}$ modified buffer A containing $50 \mathrm{mM} \mathrm{KCl}+2.5 \mathrm{mM}$

$\mathrm{NaCl}+5 \mathrm{mM} \mathrm{Co}^{2+} ; \mathbf{i}$ modified buffer A containing $50 \mathrm{mM}$ $\mathrm{KCl}+12.5 \mathrm{mM} \mathrm{NaCl}$ without $\mathrm{Co}^{2+}$. j Gray values of the 3T3 cell line measured by means of ImageJ software. These results confirm that $\mathrm{Co}^{2+}$ does not enter the $3 \mathrm{~T} 3$ cells through VGCCs $\mathrm{CAPS}+5 \mathrm{mM} \mathrm{Co}^{2+} ; \mathbf{b} 20 \mu \mathrm{M}$
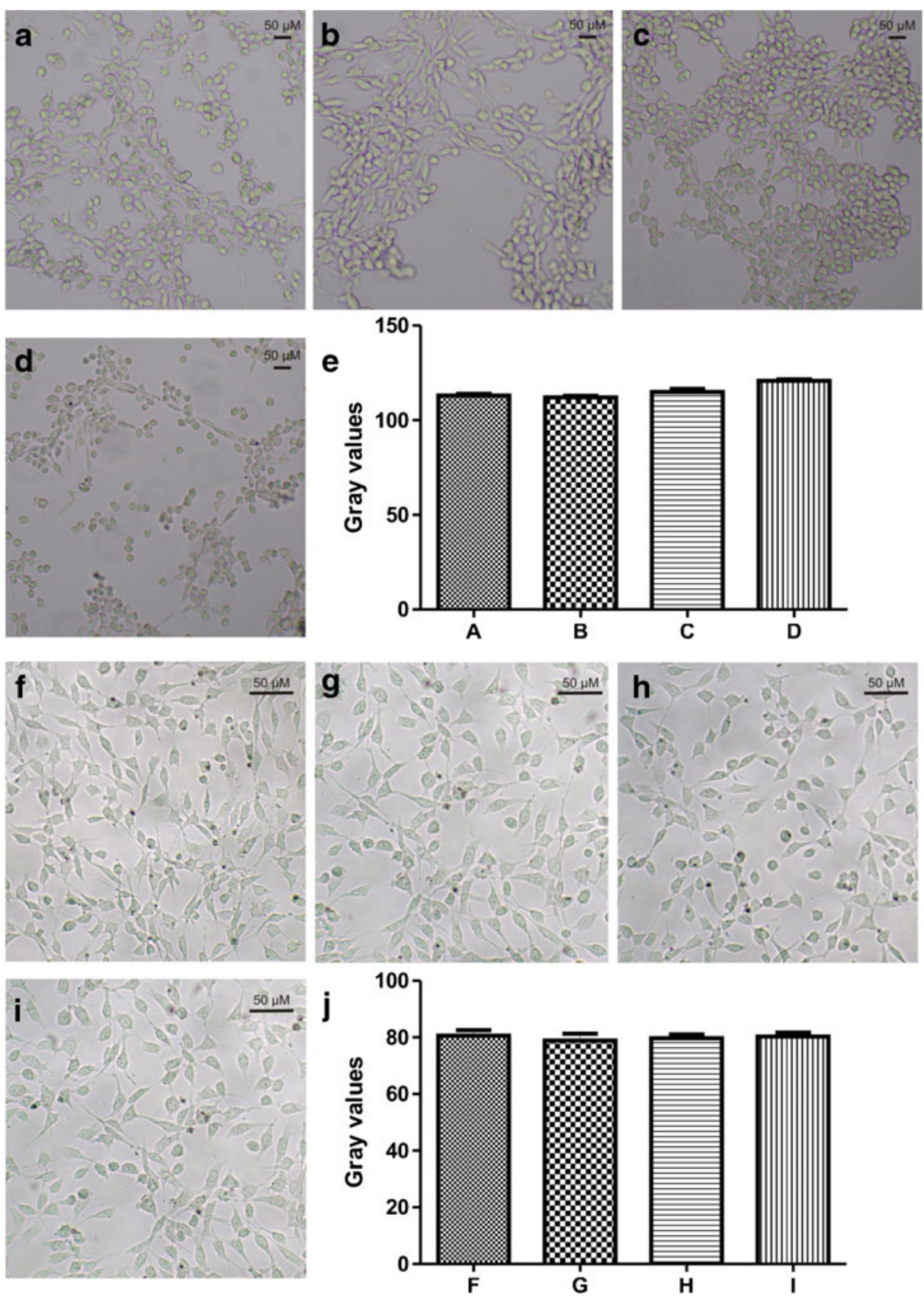

RuRed on TRPV1 mutants were therefore analysed with $4 \mu \mathrm{M}$ CAPS. The neutralization of D646 reduced the sensitivity of TRPV1 to RuRed inhibition [11]. Our ${ }^{45} \mathrm{Ca}^{2+}$-influx studies on TRPV1 point mutants revealed the following $\mathrm{IC}_{50}$ data for RuRed: $\mathrm{IC}_{50}(\mathrm{D} 646 \mathrm{~N})=12.8 \mu \mathrm{M}>\mathrm{IC}_{50}(\mathrm{~N} 628 \mathrm{~W})=$ $1.33 \mu \mathrm{M}>\mathrm{IC}_{50}(\mathrm{E} 651 \mathrm{~W})=0.94 \mu \mathrm{M}>\mathrm{IC}_{50}$ (wild type $)=$ $0.87 \mu \mathrm{M}>\mathrm{IC}_{50}(\mathrm{Y} 627 \mathrm{~W})=0.26 \mu \mathrm{M}$ (Fig. 6c), which findings correspond with published results [17]. Likewise, $\mathrm{Co}^{2+}$ inhibited the $4 \mu \mathrm{M}$ CAPS-evoked ${ }^{45} \mathrm{Ca}^{2+}$ influx in the D646N and E651W point mutants similarly as determined in the wild type. The neutralization of D646 caused no or only a minimal change in $\mathrm{IC}_{50}$. As compared with the wild type in this representative experiment, $\mathrm{Co}^{2+}$ sensitivity was slightly reduced in the D646N mutant $\left(\mathrm{IC}_{50}=18.3\right.$ vs. $\left.25.7 \mu \mathrm{M}\right)$. The Y627W, N628W and E651W mutants displayed little or no difference relative to the wild type $\left(\mathrm{IC}_{50}=18.6,16.4\right.$ and $15.3 \mu \mathrm{M}$, respectively vs. $18.3 \mu \mathrm{M}$; Fig. $6 \mathrm{~d}$ ). Based on these findings, inhibition seems to be a consequence of competition with $\mathrm{Ca}^{2+}$ for $\mathrm{M}^{2+}$-chelating sites in the pore loop domain.

\section{Discussion}

Testing the effects of various metal cations on the vanilloidinduced activity of the TRPV1 channel, we demonstrated that $\mathrm{Mg}^{2+}, \mathrm{Mn}^{2+}$ or $\mathrm{La}^{3+}$ caused little or no decrease in 
Fig. 6 Eye wipe test performed on $\mathrm{CD} 1$ mice and cobalt uptake experiments on TRPV1 point mutants. a Eye wipe responses to the corneal application of CAPS alone or together with $\mathrm{Co}^{2+}$ or CapZ. Statistical significance of inhibition was assessed by means of the paired $t$ test $(P<0.05)$. Data are means \pm SD of the results of eight independent experiments $(n=8)$. b Schematic localizations of the mutants used in the study. c, $\mathbf{d} \mathrm{IC}_{50}$ of RuRed and $\mathrm{Co}^{2+}$ determined on TRPV1 point mutants and wild type (WT). Data are means \pm SD of the results of three independent experiments. TRPV1 point mutants revealed that the binding regions of $\mathrm{Co}^{2+}$ and RuRed are different a

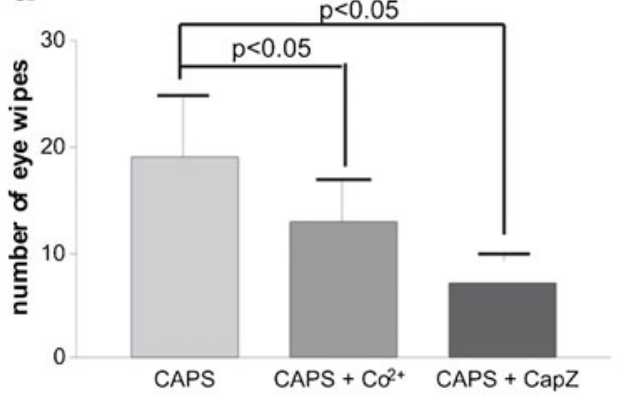

C

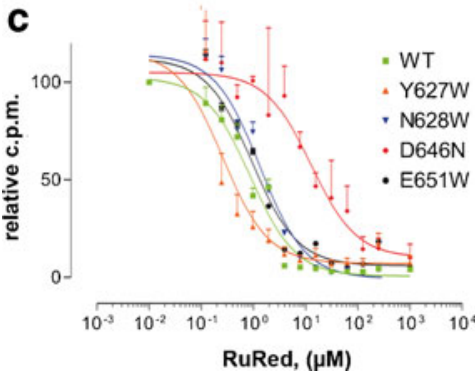

b

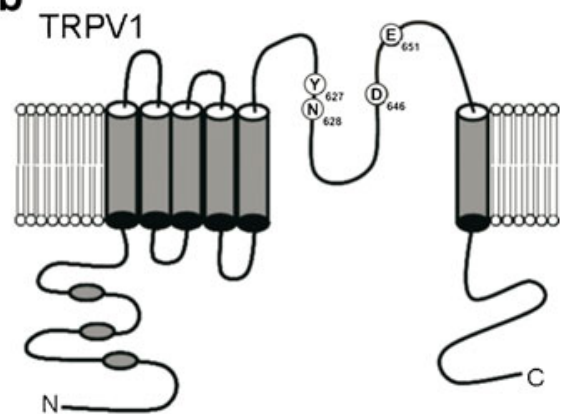

d

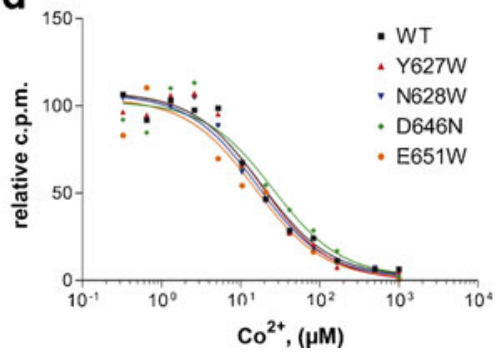

channel activity, whereas $\mathrm{Zn}^{2+}$ proved to be a weak and only partial inhibitor of the $2 \mu \mathrm{M}$ CAPS-induced ${ }^{45} \mathrm{Ca}^{2+}$ uptake. The other cations effectively blocked the vanilloid-induced $\mathrm{Ca}^{2+}$ entry into TRPV1/HaCaT cells, with the following sequence of potency: $\mathrm{Co}^{2+}>\mathrm{Cd}^{2+}>\mathrm{Ni}^{2+}>\mathrm{Cu}^{2+}$.

It was reported by Nilius et al. [29] that $\mathrm{Co}^{2+}$ reduced the inward $\mathrm{Ca}^{2+}$ current through ECaC1 (TRPV5), a close relative of TRPV1, sharing around $30 \%$ homology with it. Fast and reversible recovery of the current upon washout of the inhibitor was detected during their experiments. Furthermore, they identified other $\mathrm{M}^{2+}$-s as effective inhibitors of the $\mathrm{Ca}^{2+}$ influx. Their results indicated the following overall blocking sequence: $\mathrm{Pb}^{2+}=\mathrm{Cu}^{2+}=\mathrm{Gd}^{3+}>\mathrm{Cd}^{2+}>\mathrm{Zn}^{2+}>\mathrm{La}^{3+}>$ $\mathrm{Co}^{2+}>\mathrm{Fe}^{2+}>>\mathrm{Fe}^{3+}$. Zeng et al. found $\mathrm{Cu}^{2+}$ to be a potent inhibitor of the whole-cell current evoked by intracellular ADP-ribose through TRPM2, another member of the TRP group. The inhibitory effect of $\mathrm{Cu}^{2+}$ was irreversible, and occurred only if $\mathrm{Cu}^{2+}$ was administered in outside-out patches, suggesting that the action site is located extracellularly. The TRPM2 current was also blocked by $\mathrm{Hg}^{2+}, \mathrm{Pb}^{2+}$, $\mathrm{Fe}^{2+}$ and $\mathrm{Se}^{2+}[30]$.

In accord with the above-mentioned findings, we also observed ion influx-inhibitory effects of $\mathrm{M}^{2+}$-s on TRP channel. Depending on the TRP channel type, differences of the orders of blocking potency could be detected. Furthermore, the blocking effects of the individual cations could be reversible or irreversible, depending on the channel type. The three channels are close relatives and share high degree of sequence and structural homology with one another, which explains the similar responses to $\mathrm{M}^{2+}$-s. Having diverged from a common ancestor, TRP channels operate on uniform principles. However, during evolution
TRP superfamily has evolved for various specialized functions. TRPV1 and TRPV5, for example, belong to different subgroups of the TRPV family; TRPV1-4 are non-ionselective, whilst TRPV5-6 are highly $\mathrm{Ca}^{2+}$-selective. Hence, this functional adaptation may cause the differences in the $\mathrm{M}^{2+}$-evoked responses.

As concerns our own results, $\mathrm{Co}^{2+}$ reduced not only CAPS-induced but also heat-induced ${ }^{45} \mathrm{Ca}^{2+}$ influx. When increasing concentrations of both $\mathrm{Co}^{2+}$ and CAPS were applied, the $\mathrm{Co}^{2+}$ inhibition patterns indicated channelblocking kinetics. Our dose-response and $\mathrm{Co}^{2+}$ accumulation experiments revealed a competition for binding sites and a co-entry mechanism. We presume that $\mathrm{Co}^{2+}$ inhibits TRPV1 through its ability to bind to the ion selectivity filter of the channel: it passes through the ion channel much more slowly than $\mathrm{Ca}^{2+} \cdot \mathrm{Ca}^{2+}$ entry is also slowed down by the binding of $\mathrm{Co}^{2+}$, which occupies the appropriate amino acid residues of the ion selectivity filter. This hypothesis seems to be further supported by the findings of Sajadi [31], who determined the stability constants of the 1:1 complexes formed between $\mathrm{M}^{2+}$ and L-tryptophan and other amino acids. The sequence obtained in the case of tryptophan was $\mathrm{Ca}^{2+}<\mathrm{Mg}^{2+}<\mathrm{Mn}^{2+}<\mathrm{Co}^{2+}<\mathrm{Ni}^{2+}<\mathrm{Cu}^{2+}>$ $\mathrm{Zn}^{2+}$, which follows the Irving-Williams sequence [32]. The order of the stability constants was similar in the cases of methionine, alanine, leucine, valine and glycine. The amino acid sequence of the putative pore region is STSHRWRGPACRPPDSSYNSLYSTCLELFKFTIGMGD (Q8NER1, UniProt), containing all the tested amino acids but valine. The stability constants formed between $\mathrm{M}^{2+}$ and tryptophan were $\mathrm{Ca}^{2+}, 2.55 \pm 0.08 ; \mathrm{Mg}^{2+}, 2.84 \pm 0.08 ; \mathrm{Mn}^{2+}$, $3.34 \pm 0.05 ; \mathrm{Co}^{2+}, 4.34 \pm 0.07 ; \mathrm{Ni}^{2+}, 5.31 \pm 0.06 ; \mathrm{Cu}^{2+}$, 
$8.05 \pm 0.05$ and $\mathrm{Zn}^{2+}, 5.00 \pm 0.08$. The stability constants for $\mathrm{Mg}^{2+}$ and $\mathrm{Mn}^{2+}$ are close to that of $\mathrm{Ca}^{2+}$, so these ions can probably readily pass through the open channel of TRPV1. $\mathrm{Co}^{2+}, \mathrm{Ni}^{2+}$ and $\mathrm{Cu}^{2+}$ can be characterized by much higher complex-forming strength, elucidating the elevated TRPV1 blocking potency. Interestingly, for these three $\mathrm{M}^{2+}-\mathrm{s}$, an unexpected relationship can be observed between the stability constant and the TRPV1 blocking potency. The stronger the bond, the weaker the TRPV1 inhibition potency is. The ionic radii (in picometres) of these cations are $\mathrm{Ca}^{2+}, 100 ; \mathrm{Mg}^{2+}, 72$; $\mathrm{Mn}^{2+}, 67 ; \mathrm{Co}^{2+}, 65 ; \mathrm{Ni}^{2+}, 69 ; \mathrm{Cu}^{2+}, 73$ and $\mathrm{Zn}^{2+}, 74$ [33]. $\mathrm{Ca}^{2+}$ is likely to have the ideal ionic radius and stability constant in its reactions with amino acids in order to be effectively passed along the carbonyl groups of the peptide backbone in the ion selectivity filter and the pore loop. $\mathrm{Co}^{2+}$ has a medium stability constant and the smallest ionic radius, which is probably not adequate for efficient transport. These two parameters seem to be equally involved in the proper ion influx. The stronger the $\mathrm{M}^{2+}$-amino acid complex and the smaller the ionic radius is, the more probable it is that $\mathrm{M}^{2+}$ will block the $\mathrm{Ca}^{2+}$ influx through the TRPV1 channel. As another interesting finding, in our experiments, $\mathrm{Zn}^{2+}$ seemed to be only weak and partial inhibitor of the ion current. Its stability constant is almost as high as that of $\mathrm{Co}^{2+}$, suggesting a strong TRPV1-blocking ability, whereas its ionic radius is much larger than that of $\mathrm{Co}^{2+}$. Interestingly, the $\mathrm{IC}_{50}$ of $\mathrm{Zn}^{2+}$ is the second lowest exceeding only that of $\mathrm{Co}^{2+}$, but $\mathrm{Zn}^{2+}$ can achieve a decrease of merely $30 \%$ of the maximal ion influx.

The TRPV1 channel is a non-selective cation channel, and still shows preference for $\mathrm{Ca}^{2+}$. The sequence of permeability is $\mathrm{Ca}^{2+}>\mathrm{Mg}^{2+}>\mathrm{Na}^{+}=\mathrm{K}^{+}=\mathrm{Cs}^{+}$[3]. In addition to all these, TRPV1 also conducts protons [34]. Following prolonged exposure to agonists, TRPV1 becomes permeable even to larger organic cations, including dyes such as YO-PRO1 and FM1-43 [22] and a lidocaine derivative QX-314 [23]. Increasing agonist concentration enhances the blocking ability of $\mathrm{Co}^{2+}$, suggesting a correlation between the increased efficacy of inhibition and the different open-state conformations of the TRPV1 channel. Further experiments (involving patch-clamp recordings) would be needed to clarify the inhibitory effect of $\mathrm{Co}^{2+}$ on the fluxes of the other cations or molecules mentioned above. However, no channel blocker or antagonist of TRPV1 has been reported that is able to block the flux of only one specific ion, and antagonists seem to block all these influxes. For example, CapZ blocks the influxes of both $\mathrm{Ca}^{2+}$ and $\mathrm{Na}^{+}$ [35]. Overall, we presume that $\mathrm{Co}^{2+}$ can also block the ion currents mentioned above.

Before the exploration of TRPV1 protein, $\mathrm{Co}^{2+}$ histochemistry was a very useful tool for the identification of vanilloid-sensitive primary afferent neurons with $\mathrm{C}$-and $\mathrm{A} \delta$ fibres after in vivo experiments. $\mathrm{Co}^{2+}$ uptake and the postmortem determination of $\mathrm{Co}^{2+}$ deposits quite accurately identified $\mathrm{C}$-and $\mathrm{A} \delta$ afferents, the neuronal subset that can be activated by treatment with a vanilloid agonist, CAPS $[36,37]$. Likewise, as previously documented in a subpopulation of pseudo-unipolar neurons [38], we have now demonstrated selective vanilloid-induced $\mathrm{Co}^{2+}$ accumulation in the cytosol of DRG primary cultures and TRPV1-transfected HaCaT and 3 T3 cells. The accumulation of $\mathrm{Co}^{2+}$ could be blocked by RuRed or CapZ in a dose-dependent manner. The CAPS-induced $\mathrm{Ca}^{2+}$ and $\mathrm{Co}^{2+}$ influxes in TRPV1/3T3 cells proved to be due exclusively to the TRPV1 channel and not to VGCC activity.

$\mathrm{Co}^{2+}$ inhibited the pain-evoked defensive movements in eye wipe tests in response to pungent vanilloids. However, not only TRPV1 but also some other calcium channels of the sensory neurons, such as VGCCs, can be blocked by $\mathrm{Co}^{2+}$ [39]. VGCCs share structural homology with TRPV1 channel. The $\alpha 1$ subunit of voltage-gated calcium channels is organized in four homologous domains (I-IV), with six transmembrane segments (S1-S6) in each [40]. There is an additional region (H5) between S5 and S6, which forms a part of the pore region of the channel [41]. Within each H5 region, there exist conserved glutamate residues, significantly homologous to conventional EF-hand motifs [42], acting as the selectivity filter [43]. $\mathrm{Mn}^{2+}, \mathrm{Ni}^{2+}$ and $\mathrm{Cd}^{2+}$ in contrast with $\mathrm{Co}^{2+}$ are known to be stronger blockers of the VGCCs. $\mathrm{Cu}^{2+}, \mathrm{Mn}^{2+}$ and $\mathrm{Co}^{2+}$ blocked high-voltage activated currents conducted by $\mathrm{Ba}^{2+}$ with $\mathrm{IC}_{50}$ of 920,58 , and $65 \mu \mathrm{M}$, respectively [44, 45]. All of these ions exert their effects through high-affinity docking to the cation-binding site at the IIIS5-H5 pore region of the VACCs $[46,47]$. Since $\mathrm{Co}^{2+}$ has higher $\mathrm{IC}_{50}$ for VGCCs $(\approx 65 \mu \mathrm{M})$ than for TRPV1 $(\approx 15 \mu \mathrm{M})$, we can conclude that decrease in the number of eye wipes might be due, at least partially, to an inhibitory effect of $\mathrm{Co}^{2+}$ on TRPV1.

Positively charged tricyclics, K/R-rich basic peptides and RuRed dock to the DXEXXEXXD motif at the channel orifice [13]. Although our point mutants overlap with the RuRed docking site [11, 14, 45], our point mutant studies suggest that $\mathrm{Co}^{2+}$ has a different binding site. Accordingly, the D646N point mutant, which is crucial for RuRed binding, does not change the kinetic parameters of $\mathrm{Co}^{2+}$ inhibition in cells ectopically expressing the D646N mutant TRPV1. We carried out vanilloid-induced ${ }^{45} \mathrm{Ca}^{2+}$-uptake experiments with channel point mutants of TRPV1 in which the agonist binding site remained intact. Interestingly, no significantly decreased efficacy of $\mathrm{Co}^{2+}$ inhibition was found when ${ }^{646}$ aspartate was replaced by asparagine. Based on these results, $\mathrm{Co}^{2+}$ is supposed to evoke its effect at a different site on the pore loop region than RuRed, or to use the same negatively charged amino acids passing through the TRPV1 channel as $\mathrm{Ca}^{2+}$. This line of research on functional point mutants should be continued to determine whether $\mathrm{Co}^{2+}$ has a specific binding site on the channel orifice or not. 
Most painkiller drugs are competitive agonists and target the CAPS-binding domain [48]. As the 646DLEFTENYD acidic tetrad sequence of the TRPV1 receptor is unique among $\mathrm{Ca}^{2+}$-binding proteins, this permits the design of painkillers targeting the channel orifice of TRPV1 and acting as channel blockers. A better understanding of the structural background and dynamics of the competition of $\mathrm{Ca}^{2+}$ with other $\mathrm{M}^{2+}$ for entry may result in the discovery of novel channel blocker painkillers. Furthermore, our data can contribute to a better understanding of the structures and functions of all TRP superfamily members. The specific effect of the selected $\mathrm{M}^{2+}$-s on the given ion channel pore region can serve as a valuable constraint during in silico modelling of the pore region. By comparing the different cation action profiles of pore regions, the model can be finetuned. The mechanism of $\mathrm{Co}^{2+}$-mediated inhibition provides screening for adjuvant therapeutics with higher selectivity than that of AMI, an approved drug currently used in clinical practice, but with only limited efficacy and with serious side effects.

Acknowledgments The excellent technical assistance of Erzsébet Kusz in the preparation of the cell lines is acknowledged. This work was supported by grants from the National Office for Research and Technology (OMFB-01630; OMFB-01703, OMFB-01576/2006 and BAROSS_DA07-DA_TECH_07-2008-0043). TL was supported by a Postdoctoral Fellowship of the Zoltán Magyary Foundation. ZO was supported by Marie Curie European Re-integration Grant MCIRG030854-PAINKILLER; Ányos Jedlik Program NKFP-1-00019/ 2005; GVOP-3.3.1-05/1.-2005-05-0057/3.0, and BAROSS_DA07DA TECH 07-2008-0028. CV was supported by grants from the National Office for Research and Technology (OM-00051/2005, OMFB-01575/2006, ERC HU 09 3D TRPV1 OMFB-01813/2009 and TÁMOP-4.2.1.B-09/1/KONV) and the Hungarian Ministry of Health (552/2006). GS and CV are grateful for the award of Bolyai Fellowships of the Hungarian Academy of Sciences. The authors would like to express their appreciation to our native speaker lector for proofreading the manuscript.

Open Access This article is distributed under the terms of the Creative Commons Attribution License which permits any use, distribution, and reproduction in any medium, provided the original author(s) and the source are credited.

\section{References}

1. Latorre R (2009) Perspectives on TRP channel structure and the TRPA1 puzzle. J Gen Physiol 133(3):227-229

2. Tender GC, Walbridge S, Olah Z, Karai L, Iadarola M, Oldfield EH, Lonser RR (2005) Selective ablation of nociceptive neurons for elimination of hyperalgesia and neurogenic inflammation. $\mathrm{J}$ Neurosurg 102(3):522-525

3. Caterina MJ, Schumacher MA, Tominaga M, Rosen TA, Levine JD, Julius D (1997) The capsaicin receptor: a heat-activated ion channel in the pain pathway. Nature 389(6653):816-824. doi:10.1038/39807

4. Naziroglu M, Dikici DM, Dursun S (2012) Role of oxidative stress and $\mathrm{Ca}(2)(+)$ signaling on molecular pathways of neuropathic pain in diabetes: focus on TRP channels. Neurochem Res 37(10):20652075. doi:10.1007/s11064-012-0850-x

5. Gavva NR, Klionsky L, Qu Y, Shi L, Tamir R, Edenson S, Zhang TJ, Viswanadhan VN, Toth A, Pearce LV, Vanderah TW, Porreca F, Blumberg PM, Lile J, Sun Y, Wild K, Louis JC, Treanor JJ (2004) Molecular determinants of vanilloid sensitivity in TRPV1. J Biol Chem 279(19):20283-20295. doi:10.1074/ jbc.M312577200M312577200

6. Olah Z, Karai L, Iadarola MJ (2002) Protein kinase C(alpha) is required for vanilloid receptor 1 activation. Evidence for multiple signaling pathways. J Biol Chem 277(38):35752-35759

7. Brown DC, Iadarola MJ, Perkowski SZ, Erin H, Shofer F, Laszlo KJ, Olah Z, Mannes AJ (2005) Physiologic and antinociceptive effects of intrathecal resiniferatoxin in a canine bone cancer model. Anesthesiology 103(5):1052-1059

8. Karai L, Brown DC, Mannes AJ, Connelly ST, Brown J, Gandal M, Wellisch OM, Neubert JK, Olah Z, Iadarola MJ (2004) Deletion of vanilloid receptor 1-expressing primary afferent neurons for pain control. J Clin Invest 113(9):1344-1352

9. Kedei N, Szabo T, Lile JD, Treanor JJ, Olah Z, Iadarola MJ, Blumberg PM (2001) Analysis of the native quaternary structure of vanilloid receptor 1. J Biol Chem 276(30):28613-28619. doi:10.1074/jbc.M103272200M103272200

10. Tominaga M, Caterina MJ, Malmberg AB, Rosen TA, Gilbert H, Skinner K, Raumann BE, Basbaum AI, Julius D (1998) The cloned capsaicin receptor integrates multiple pain-producing stimuli. Neuron 21(3):531-543

11. Garcia-Martinez C, Morenilla-Palao C, Planells-Cases R, Merino $\mathrm{JM}$, Ferrer-Montiel A (2000) Identification of an aspartic residue in the P-loop of the vanilloid receptor that modulates pore properties. J Biol Chem 275(42):32552-32558. doi:10.1074/ jbc.M002391200M002391200

12. Jara-Oseguera AN-PA, Szallasi A, Islas L, Rosenbaum T (2010) Molecular mechanisms of TRPV1 channel activation. Open Pain J 3:68-81

13. Olah Z, Josvay K, Pecze L, Letoha T, Babai N, Budai D, Otvos F, Szalma S, Vizler C (2007) Anti-calmodulins and tricyclic adjuvants in pain therapy block the TRPV1 channel. PLoS One 2(6):e545

14. Himmel HM, Kiss T, Borvendeg SJ, Gillen C, Illes P (2002) The arginine-rich hexapeptide R4W2 is a stereoselective antagonist at the vanilloid receptor 1 : a Ca2+ imaging study in adult rat dorsal root ganglion neurons. J Pharmacol Exp Ther 301(3):981-986

15. Enyeart JJ, Xu L, Enyeart JA (2002) Dual actions of lanthanides on ACTH-inhibited leak $\mathrm{K}(+)$ channels. Am J Physiol Endocrinol Metab 282(6):E1255-1266

16. Olah Z, Lehel C, Jakab G, Anderson WB (1994) A cloning and epsilon-epitope-tagging insert for the expression of polymerase chain reaction-generated cDNA fragments in Escherichia coli and mammalian cells. Anal Biochem 221(1):94-102

17. Kitaguchi T, Swartz KJ (2005) An inhibitor of TRPV1 channels isolated from funnel Web spider venom. Biochemistry 44 (47):15544-15549

18. Farkas B, Bonnekoh B, Mahrle G (1991) Repeated treatment with dithranol induces a tolerance reaction in keratinocytes in vitro. Arch Dermatol Res 283(5):337-341

19. Pecze L, Szabo K, Szell M, Josvay K, Kaszas K, Kusz E, Letoha T, Prorok J, Koncz I, Toth A, Kemeny L, Vizler C, Olah Z (2008) Human keratinocytes are vanilloid resistant. PLoS One 3(10): e3419

20. Clapham DE, Montell C, Schultz G, Julius D (2003) International Union of Pharmacology. XLIII. Compendium of voltage-gated ion channels: transient receptor potential channels. Pharmacol Rev 55 (4):591-596. doi:10.1124/pr.55.4.655/4/591

21. Marshall IC, Owen DE, Cripps TV, Davis JB, McNulty S, Smart D (2003) Activation of vanilloid receptor 1 by resiniferatoxin 
mobilizes calcium from inositol 1, 4, 5-trisphosphate-sensitive stores. Br J Pharmacol 138(1):172-176

22. Chung MK, Guler AD, Caterina MJ (2008) TRPV1 shows dynamic ionic selectivity during agonist stimulation. Nat Neurosci 11 (5):555-564

23. Binshtok AM, Bean BP, Woolf CJ (2007) Inhibition of nociceptors by TRPV1-mediated entry of impermeant sodium channel blockers. Nature 449(7162):607-610. doi:10.1038/nature06191

24. Fernihough J, Gentry C, Bevan S, Winter J (2005) Regulation of calcitonin gene-related peptide and TRPV1 in a rat model of osteoarthritis. Neurosci Lett 388(2):75-80. doi:10.1016/ j.neulet.2005.06.044

25. Ji RR, Samad TA, Jin SX, Schmoll R, Woolf CJ (2002) p38 MAPK activation by NGF in primary sensory neurons after inflammation increases TRPV1 levels and maintains heat hyperalgesia. Neuron 36(1):57-68

26. Malin S, Molliver D, Christianson JA, Schwartz ES, Cornuet P, Albers KM, Davis BM (2011) TRPV1 and TRPA1 function and modulation are target tissue dependent. J Neurosci 31(29):1051610528. doi:10.1523/JNEUROSCI.2992-10.2011

27. Zhang X, Huang J, McNaughton PA (2005) NGF rapidly increases membrane expression of TRPV1 heat-gated ion channels. Embo J 24(24):4211-4223. doi:10.1038/sj.emboj.7600893

28. Pecze L, Pelsoczi P, Kecskes M, Winter Z, Papp A, Kaszas K, Letoha T, Vizler C, Olah Z (2009) Resiniferatoxin mediated ablation of TRPV1+ neurons removes TRPA1 as well. Can J Neurol Sci 36(2):234-241

29. Nilius B, Prenen J, Vennekens R, Hoenderop JG, Bindels RJ, Droogmans G (2001) Pharmacological modulation of monovalent cation currents through the epithelial $\mathrm{Ca} 2+$ channel $\mathrm{ECaC} 1 . \mathrm{Br} \mathrm{J}$ Pharmacol 134(3):453-462. doi:10.1038/sj.bjp.0704272

30. Zeng B, Chen GL, Xu SZ (2012) Divalent copper is a potent extracellular blocker for TRPM2 channel. Biochem Biophys Res Commun 424(2):279-284. doi:10.1016/j.bbrc.2012.06.107

31. Sajadi SAA (2011) Complex bilding behavior of L-tryptophan and related amino acids, a comparative investigation. Am J Chem 1 (2):60-64. doi:10.5923/j.chemistry.20110102.13

32. Irving H, Williams RJP (1953) The stability of transition-metal complexes. J Chem Soc (637):3192-3210. doi:10.1039/JR9530003192

33. Shannon R (1976) Revised effective ionic radii and systematic studies of interatomic distances in halides and chalcogenides. Acta Crystallogr A 32(5):751-767. doi:10.1107/S0567739476001551

34. Vulcu SD, Liewald JF, Gillen C, Rupp J, Nawrath H (2004) Proton conductance of human transient receptor potentialvanilloid type-1 expressed in oocytes of Xenopus laevis and in Chinese hamster ovary cells. Neuroscience 125(4):861-866. doi:10.1016/j.neuroscience.2004.02.032
35. Grant ER, Dubin AE, Zhang SP, Zivin RA, Zhong Z (2002) Simultaneous intracellular calcium and sodium flux imaging in human vanilloid receptor 1 (VR1)-transfected human embryonic kidney cells: a method to resolve ionic dependence of VR1mediated cell death. J Pharmacol Exp Ther 300(1):9-17

36. Hu-Tsai M, Winter J, Woolf CJ (1992) Regional differences in the distribution of capsaicin-sensitive target-identified adult rat dorsal root ganglion neurons. Neurosci Lett 143(1-2):251-254

37. Winter J, Evison CJ, O'Brien C, Benowitz L, Lindsay RM, Mulderry P, Woolf C (1992) Neurotoxic damage evokes regenerative responses from adult rat sensory neurones. Neurosci Lett 146(1):48-52

38. Reichling DB, Barratt L, Levine JD (1997) Heat-induced cobalt entry: an assay for heat transduction in cultured rat dorsal root ganglion neurons. Neuroscience 77(2):291-294

39. Nishimura T, Krier J, Akasu T (1993) Effects of vasoactive intestinal contractor on voltage-activated $\mathrm{Ca} 2+$ currents in feline parasympathetic neurons. Am J Physiol 265(6.1):1158-1168

40. Catterall WA, Perez-Reyes E, Snutch TP, Striessnig J (2005) International Union of Pharmacology. XLVIII. Nomenclature and structure-function relationships of voltage-gated calcium channels. Pharmacol Rev 57(4):411-425. doi:10.1124/pr.57.4.5

41. Guy HR, Conti F (1990) Pursuing the structure and function of voltage-gated channels. Trends Neurosci 13(6):201-206

42. Doughty SW, Blaney FE, Orlek BS, Richards WG (1998) A molecular mechanism for toxin block in N-type calcium channels. Protein Eng 11(2):95-99

43. Mikala G, Bahinski A, Yatani A, Tang S, Schwartz A (1993) Differential contribution by conserved glutamate residues to an ion-selectivity site in the L-type $\mathrm{Ca} 2+$ channel pore. Febs Lett 335(2):265-269

44. Castelli L, Tanzi F, Taglietti V, Magistretti J (2003) Cu2+, Co2+, and $\mathrm{Mn} 2+$ modify the gating kinetics of high-voltage-activated $\mathrm{Ca} 2+$ channels in rat palaeocortical neurons. J Membr Biol 195 (3):121-136

45. Hagiwara S, Byerly L (1981) Calcium channel. Annu Rev Neurosci 4:69-125

46. Thevenod F, Jones SW (1992) Cadmium block of calcium current in frog sympathetic neurons. Biophys J 63(1):162-168

47. Winegar BD, Kelly R, Lansman JB (1991) Block of current through single calcium channels by $\mathrm{Fe}, \mathrm{Co}$, and Ni. Location of the transition metal binding site in the pore. J Gen Physiol 97 (2):351-367

48. Gavva NR, Tamir R, Klionsky L, Norman MH, Louis JC, Wild KD, Treanor JJ (2005) Proton activation does not alter antagonist interaction with the capsaicin-binding pocket of TRPV1. Mol Pharmacol 68(6):1524-1533 
III. 


\title{
Functionally important amino acid residues in the transient receptor potential vanilloid 1 (TRPV1) ion channel - an overview of the current mutational data
}

\author{
Zoltán Winter ${ }^{1 *}$, Andrea Buhala ${ }^{1}$, Ferenc Ötvös ${ }^{2}$, Katalin Jósvay $^{1,2}$, Csaba Vizler $^{2}$, György Dombi ${ }^{1}$ \\ Gerda Szakonyi ${ }^{1}$ and Zoltán Oláh ${ }^{1,3}$
}

\begin{abstract}
This review aims to create an overview of the currently available results of site-directed mutagenesis studies on transient receptor potential vanilloid type 1 (TRPV1) receptor. Systematization of the vast number of data on the functionally important amino acid mutations of TRPV1 may provide a clearer picture of this field, and may promote a better understanding of the relationship between the structure and function of TRPV1. The review summarizes information on 112 unique mutated sites along the TRPV1, exchanged to multiple different residues in many cases. These mutations influence the effect or binding of different agonists, antagonists, and channel blockers, alter the responsiveness to heat, acid, and voltage dependence, affect the channel pore characteristics, and influence the regulation of the receptor function by phosphorylation, glycosylation, calmodulin, PIP2, ATP, and lipid binding. The main goal of this paper is to publish the above mentioned data in a form that facilitates in silico molecular modelling of the receptor by promoting easier establishment of boundary conditions. The better understanding of the structure-function relationship of TRPV1 may promote discovery of new, promising, more effective and safe drugs for treatment of neurogenic inflammation and pain-related diseases and may offer new opportunities for therapeutic interventions.
\end{abstract}

Keywords: TRPV1, Vanilloid, Amino acid, Mutants, Molecular modelling, Structure

\section{Introduction}

This review aims to create an overview of the currently available results of site-directed mutagenesis studies on transient receptor potential vanilloid type 1 (TRPV1) receptor. Systematization of the vast number of data on the functionally important amino acid mutations of TRPV1 may provide a clearer picture of this field, and may promote a better understanding of the relationship between the structure and function of TRPV1.

The first few sections provide a brief introduction of the transient receptor potential family and the TRPV1 ion channel. The following sections compile the positions crucial for the different channel functions and the

\footnotetext{
* Correspondence: winter.zoltan@brc.mta.hu

'Institute of Pharmaceutical Analysis, Faculty of Pharmacy, University of Szeged, Szeged, Hungary

Full list of author information is available at the end of the article
}

amino acid changes of these 112 unique mutated sites of TRPV1. The information collected in this form may serve as a powerful tool for in silico molecular modelling by facilitating the establishment of boundary conditions.

All mutations and positions discussed in this paper generally refer to the rat ortholog (rTRPV1) of the TRPV1. All results relating to other species will be highlighted in the text.

\section{Transient receptor potential channels}

The first TRP channel was discovered in 1969 by Cosens and Manning, who isolated a mutant photoreceptor from Drosophila melanogaster, which caused the specimen to become temporally blind upon exposure to bright light $[1,2]$. TRP channels are one of the largest families of ion channels. The mammalian TRP superfamily consisting of 28 TRP cation channels can be subdivided into six 
subfamilies: the TRPC ("Canonical"), TRPV ("Vanilloid"), TRPM ("Melastatin"), TRPP ("Polycystin"), TRPML ("MucoLipin") and the TRPA ("Ankyrin") groups $[3,4]$.

All TRP channels are tetramers assembled with fourfold symmetry from the individual subunits containing six putative transmembrane segments (TMs). The region between the fifth and the sixth TMs, including a putative pore loop, forms the ion permeation pathway [5]. The amino and carboxyl ( $\mathrm{N}$ - and $\mathrm{C}$-) termini are located intracellularly and vary vastly in length and amino acid sequence. These cytoplasmic regions contain diverse wellrecognized domains and motifs that are likely to be involved in channel assembly, activation and regulation through protein-protein and/or protein-ligand interactions. Most TRP channels are cation-selective, and some are highly selective for $\mathrm{Ca}^{2+}$ or $\mathrm{Mg}^{2+}$ [4]. In accordance with their amino acid sequence diversity, TRP channels exhibit various activation and modulatory mechanisms, such as those involving in the stimulation by G-protein-coupled receptors, extracellular and intracellular ligands (including $\mathrm{H}^{+}, \mathrm{Ca}^{2+}$ and $\mathrm{Mg}^{2+}$ ), phosphatidylinositol-4,5-bisphosphate (PIP2), temperature, and mechanical stretch [6].

The accumulating evidence that TRP channels are important components of several human diseases has created a huge interest for these channels as novel potential drug targets. Comprehensive reviews have been published on the modulation and potential pharmaceutical application of TRP channels [7-11].

\section{TRPV subfamily}

The TRPV family includes six mammalian ion channels, TRPV1-TRPV6, with a large C- and an even larger Nterminal cytoplasmatic domain containing ankyrin repeat domains (ARD) [12,13]. Ankyrin repeats, the 33-residue sequence motifs, are essential in channel function, ATP, PIP2, and calmodulin (CaM) binding [14] and proteinprotein interactions $[15,16]$. They are present in many proteins, with functions including signalling, cytoskeleton integrity, transcription and cellular localization $[17,18]$.

As polymodal thermo- and chemosensitive channels, TRPV1-TRPV4 are non-selective for cations and modestly permeable to $\mathrm{Ca}^{2+}$. In contrast, TRPV5 and TRPV6 are the only highly $\mathrm{Ca}^{2+}$-selective channels in the TRP family, and both channels are tightly regulated by the intracellular $\mathrm{Ca}^{2+}$ concentration $[10,19,20]$.

TRPV channels can be activated through a variety of mechanisms. TRPV1-TRPV4 can act as thermosensors at a molecular level. Interestingly, each of these channels has a different thermal threshold for activation. When expressed in transfected permanent cell lines (HEK293 and $\mathrm{CHO}$ cells) and in frog oocytes [4,21,22], TRPV2, TRPV1, TRPV3 and TRPV4 are activated at $52^{\circ} \mathrm{C}, 43^{\circ} \mathrm{C}$, $33^{\circ} \mathrm{C}$, and below $33^{\circ} \mathrm{C}$, respectively. The TRPV family members, except for TRPV1, are insensitive to vanilloid compounds [4]. TRPV3 can be activated by essential oils from clove (eugenol), thyme (thymol) and oregano (carvacrol) [23]. Like TRPV1, TRPV3 is also activated by camphor [24]. TRPV4 can be activated by cell swelling caused by 5',6'-epoxyeicosatrienoic acid [25]. TRPV5 and TRPV6, originally named ECaC [26] and CAT1 [27], are $\mathrm{Ca}^{2+}$ entry channels responsible for $\mathrm{Ca}^{2+}$ absorption in the kidney and intestine, respectively.

\section{TRPV1}

In 1997, the breakthrough work of Michael Caterina and colleagues in the field of somatic sensory biology and pain research led to the cloning of the vanilloid (capsaicin) receptor, TRPV1 [28]. The cloning of TRPV1 proved to be a significant step in the understanding of molecular mechanisms that underlie the transduction of noxious thermal and chemical stimuli by sensory neurones [9].

\section{Characteristics of TRPV1}

As a TRPV subfamily member, TRPV1 can be characterized by some key properties that are common among the members of the family. It is built from four individual subunits containing six TMs [29]. TRPV1 has a pore-forming hydrophobic stretch between TM5 and TM6 and is believed to exist as a homo- or heteromeric complex form [28-30] (Figure 1).

The TRPV1 receptor is a non-selective ligand-gated cation channel with a ninefold higher permeability for $\mathrm{Ca}^{2+}$ than for $\mathrm{Na}^{+}$. It is an integrator of a wide variety of exogenous and endogenous physical and chemical stimuli, including capsaicin (CAPS), noxious heat $\left(>43^{\circ} \mathrm{C}\right)$ and protons $(\mathrm{pH}<5.2)$. Strictly speaking, CAPS and its biological analogs isolated from plants and animals are essentially sensitizers, because they act by lowering the thermal "physiological" activation threshold of TRPV1. Nevertheless, because these compounds bind directly to TRPV1, they are conveniently considered as direct activators, in contrast to compounds that do not bind TRPV1 and affect its functioning indirectly, which are referred to as sensitizers [31]. Besides CAPS, many complex amphiphilic molecules have been shown to activate or inhibit TRPV1. These include polyring compounds such as resiniferatoxin (RTX), a highly irritant diterpene related to the phorbol esters [32] which is almost 20fold more potent than CAPS [33]. Species-specific differences in RTX potency have also been described, for example, RTX is a more potent agonist on rTRPV1 than its human ortholog (hTRPV1) [34,35]. Further molecules with similar structures, such as quinazolinone [36], evodiamine [37] and 17- $\beta$-estradiol [38], as well as molecules with long acyl and amide chains, such as anandamide [39-45], olvanil and omega-3 polyunsaturated fatty acids can also activate the channel [46]. Other natural TRPV1 agonists are 12-hydroperoxyeicosatetraenoic acid 
(12-HPETE) and $\mathrm{N}$-arachidonoyl dopamine (NADA) [42,47-49]. Piperine from black pepper, eugenol from cloves and zingerone from ginger have also been shown to activate TRPV1 [50,51]. Additionally, gingerols, present in raw ginger, and shogaols, which are dehydration products of gingerols present in steamed ginger, both of which possess a vanillyl moiety, also activate TRPV1 $[35,45,52,53]$. Since both CAPS and its analogues are lipophilic, they are able to cross the cell membrane and act on binding sites present on the intracellular surface of TRPV1 [54]. TRPV1 can also be activated by 2 -aminoethoxydiphenyl borate (2-APB). 2-APB inhibits both IP3 receptors and the majority of TRP channels, though at higher concentrations it activates TRPV1, TRPV2 and TRPV3 [11,55]. There has been debates about whether TRPV1 can [56-59] or can not [60-63] be activated by AITC. Stimuli are detected and transduced through opening of the ion channel, which results in the entry of cations such as $\mathrm{Ca}^{2+}$ and $\mathrm{Na}^{+}$ to the neurone [28]. Due to its uniqueness in its diverse operational features, which differ from the classical, more restrained proteins of voltage-gated and ligand-gated channels, as well as from the G-protein-coupled receptors, TRPV1 was dubbed "multisteric nocisensor" in the recent review paper by Szolcsányi and Sándor [64].

The inorganic dye Ruthenium Red (RuRed), is used in histology to stain aldehyde fixed mucopolysaccharides. Long before the cloning of TRPV1 RuRed was demonstrated to be able to inhibit CAPS-induced responses in sensory neurones [65]. Later it was shown that RuRed is a non-competitive antagonist not only for TRPV1 but for most other TRP channels functioning as a pore blocker [31]. The first competitive antagonist identified for TRPV1 was the CAPS analogue capsazepine (CapZ). CapZ is a relative potent antagonist on hTRPV1 but demonstrated much less potency on rTRPV1 [66,67], illustrating the differences between species that is common for many TRPV1 antagonists. Since the discovery of CapZ the number of TRPV1 patents has exceeded 1,000. Most of these antagonists show high affinity to TRPV1 and are competitive antagonists binding to the same site as CAPS and many of them have also demonstrated in vivo effects in various pain models [68]. The halogenated version of RTX, iodoresiniferatoxin (I-RTX) has been identified as a high-affinity antagonist of the TRPV1 channel and similarly to RTX, it also exert different potency on the hTRPV1 and rTRPV1 [69]. R4W2, a small positively charged peptide was identified to be non-competitive antagonist blocker of recombinant TRPV1 channels expressed in Xenopus oocytes [70], blocking CAPS-operated ionic currents with micromolar efficacy in a weakly voltage-dependent manner. R4W2 was later found to be competitive antagonist of TRPV1 also in primary cultures of adult rat dorsal root ganglion neurons (DRGs) [71].
Besides its involvement in pain sensation, TRPV1 displays a low level of activity at normal body temperature $[72,73]$. Constitutive activity of TRPV1 is essential for regulation of body temperature, evidenced by high fever as a adverse side effect of many TRPV1 blockers during clinical trials for their efficacy in management or prophylaxis of pain $[74,75]$. Moreover, at room temperature $\left(24^{\circ} \mathrm{C}\right)$ and $\mathrm{pH}$ 7.3, TRPV1 behaves as a voltage-gated outwardly rectifying channel, since it can be activated, in the absence of any agonist, by depolarizing voltages $(>+60 \mathrm{mV})$ [76].

One striking feature of TRPV1 is that the receptor can be sensitized and desensitized. This fact suggests that the TRPV1 function is subject to extensive modulation, which has significant implications for the involvement of TRPV1 in physiological and pathophysiological conditions. Some inflammatory mediators in damaged tissues including growth factors, neurotransmitters, peptides or small proteins, lipids, chemokines and cytokines sensitize TRPV1 to its agonists [77]. Even in concentrations that fail to activate a current, CAPS can sensitize TRPV1 channels to protons and heat. Similarly, protons can sensitize TRPV1 channels to CAPS and heat $[78,79]$. The elevation of temperature or local acidity can in principle augment the efficacies of partial agonists, transforming them from weakly or non-pain-producing ligands into noxious chemicals $[80,81]$. Whereas protons sensitize TRPV1 directly, most of the mediators work through receptor pathways, which include receptor tyrosine kinases and Gprotein-coupled receptors. It has been reported that phosphorylation by protein kinase A (PKA) [82-84] and protein kinase C (PKC) can sensitize TRPV1 to CAPS, protons or heat $[47,78,85-88]$. The phosphorylation of TRPV1 by PKC acts to potentiate CAPS- or proton-evoked responses and reduces the temperature threshold for TRPV1 activation. Others have suggested that isoforms of PKC $\alpha$ [89] or PKC $\mu$ [90] are responsible for the effects described above. Protein kinase $\mathrm{D} / \mathrm{PKC} \mu$ is a member of the protein kinase D serine/threonine kinase family that exhibits structural, enzymological and regulatory features distinct from those of the PKCs, with which they are related. TRPV1 can also be phosphorylated by $\mathrm{Ca}^{2+} \mathrm{CaM}$-dependent kinase II (CaMKII) [91], or Src kinase [92], whilst the phosphatase calcineurin produces desensitization of the TRPV1 receptor [93]. TRPV1 undergoes two types of desensitization on activation by CAPS or protons: acute (short-term) desensitization and tachyphylaxis or loss of sensitivity to repeated stimulations $[14,94]$. Physiologically, TRPV1 desensitization can lead to the adaptation of peripheral neurones to pain perception. The regulatory lipid PIP2 is a putative intracellular modulator of TRPV1, although there is some debate as to whether it sensitizes or desensitizes the channel. Mutations in a C-terminal cytosolic region of TRPV1 indicate an inhibitory role for PIP2 [95]. However, others have found that PIP2 sensitizes TRPV1 and that 
depletion leads to desensitization [14,96-99]. Another important membrane lipid in terms of TRPV1 activity is cholesterol. Cholesterol is a major component of plasma membranes and is enriched in lipid rafts. It has been shown to modify the function of many classes of ion channels [100]. Cholesterol can modify channel activity indirectly by altering physical properties of the surrounding lipid bilayer, and the highly ordered lipid rafts can serve as organizing centres for many signalling processes [101]. In recent years compelling evidence has emerged of a specific interaction between cholesterol and several channels [100-103]. A supporting role of sphingomyelin and gangliosides was also demonstrated [104]. Sántha et al. demonstrated that inhibition of neuronal ganglioside synthesis by inhibition of glucosylceramide synthase reversibly decreased the CAPS-induced activation and TRPV1 expression of cultured dorsal root ganglion neurons, apparently leaving other markers of nociceptive neurons, such as CGRP and IB4, unaffected [105]. Intracellular ATP can also sensitize TRPV1.

TRPV1 binds and is modulated by $\mathrm{Ca}^{2+} / \mathrm{CaM}$, a ubiquitous $\mathrm{Ca}^{2+}$ sensor $[106,107]$. An increase in intracellular $\mathrm{Ca}^{2+}$ concentration causes TRPV1 desensitization, and CaM plays a role in mediating this effect [106-108]. $\mathrm{CaM}$ interacts in vitro with isolated peptides from the TRPV1 $\mathrm{N}$-terminal region in a $\mathrm{Ca}^{2+}$-dependent manner [107], and also binds to the TRPV1 C-terminal region in a $\mathrm{Ca}^{2+}$-independent manner [106]. The response of TRPV1 to heat can be modified by tyrosine kinases or G-protein-coupled receptors. Channel activation can occur even at normal body temperatures [78,109,110]. Reducing agents such as dithiothreitol (DTT) strongly increase the thermally induced activity of the TRPV1 channel [111]. Moreover, the oxidizing agents diamide and chloramine- $\mathrm{T}$ also facilitate thermally induced TRPV1-mediated currents [112]. Alkylating agents, such as N-ethylmaleimide also strongly and irreversibly affect heat-evoked responses from TRPV1, lowering the thermal activation threshold in a DTT-dependent manner [112]. It follows from these data that TRPV1 is targeted by redoxactive substances that directly modulate the channel activity, and that channel potentiation may occur under altered redox states in a tissue, e.g., during ischaemia and/or inflammation, presumably leading to hyperalgesia.

Inflammatory agents such as bradykinin, serotonin, histamine, or prostaglandins can further stimulate TRPV1 activity, either by PKC-dependent pathways [110,113,114], by releasing the channel from PIP2-dependent inhibition $[99,115]$, by a PKA-mediated recovery from inactivation [116,], or by the formation of 12-HPETE [78,117].

\section{Vitally important functions of TRPV1}

The role of the TRP channels in pain and neurogenic inflammation have been very well covered by previous authors (e.g. [118-121]) reflecting the enormity of the role that these channels play in sensory nerve function at both a central and peripheral level [122]. Thus TRPV1 plays a key role in the development of the burning pain sensation associated with acute exposure to heat or CAPS, and with inflammation in peripheral tissues $[28,91]$. The receptor seems to play important role in certain chronic pain conditions, such as neuropathic pain, osteoarthritis, bone cancer pain, inflammatory bowel disease and migraine $[9,123,124]$. Its role in the central nervous system (CNS) is known to involve pain processing and modulation, neurogenesis [125] and thermoregulation [126], amongst others, but is currently less well understood.

Jancsó and Wollemann [127] have reported that CAPS stimulates adenylate cyclase activity in the rat cerebral cortex in vitro. Furthermore, direct injection of CAPS into the preoptic area of the anterior hypothalamus [126] or i.c.v. region [128] of the rat brain causes hypothermia, suggesting a role for this channel in thermoregulation. Similarly, systemic administration of TRPV1 antagonists such as AMG517 [73], AMG0347 [129] and A-425619 [130] causes an increase in body temperature within approximately $1 \mathrm{~h}$ of treatment [122]. However, antagonist-induced hyperthermia may not be mediated by hypothalamic TRPV1 as peripherally-restricted antagonists still have the capacity to cause an increase in body temperature [131].

Within the periphery, recent evidence has located TRPV1 on a variety of non-neuronal tissues (for more details see Table two in the paper of Fernandes et al. [122]). Although TRPV1 channel expression has been shown in a wide variety of tissues, evidence of functionality has not yet been demonstrated for all of these.

One of the first cell types in which functionality was first identified is epidermal keratinocytes. Inoue et al. [132] demonstrated that both CAPS and acidification produced elevations in the intracellular calcium concentration in cultured human epidermal keratinocytes that could be inhibited by the TRPV1 antagonist, CapZ [122]. Similarly, treatment of human skin fibroblasts with CAPS induced significant changes in the membrane current and the intracellular calcium level that were antagonized by CapZ [133]. It is therefore clear that TRPV1 is expressed and functional away from sensory nerves.

Physiological or pathophysiological effects of nonneuronal TRPV1 have been implicated in inflammation, infection and immunity, the cardiovascular system and in conditions such as obesity [122].

A physiological/pathophysiological role for non-neuronal TRPV1 is perhaps nowhere more apparent than in the case of inflammation, infection and immunity. Although the effects of these TRPV1 channels are non-neuronal, it is evident that they may well impact indirectly upon pain and/or neurogenic inflammation [122]. Keratinocytes functionally 
express TRPV1. These cells play an important role in maintaining the integrity of the immune response in skin as well as stimulating cutaneous inflammation via prostanoid and cytokine release [134]. TRPV1 activation by CAPS causes an increase in COX2 expression in human keratinocytes with a concomitant increase in $\mathrm{PGE}_{2}$ levels in vitro [135]. An increase in IL-8 is also observed [135] Stimulation of inflammatory mediator release by TRPV1 agonists from keratinocytes could well have a significant effect upon sensory nerves that have a high density in skin [122].

However, there is accumulating evidence that TRPV1 has functional roles away from sensory nerve activity [122]. As well as keratinocytes, peripheral blood mononuclear cells (PBMCs) are also directly affected by TRPV1 activation. For example, PBMCs undergo apoptosis when stimulated with CAPS or RTX, an effect that is reversed by the TRPV1 antagonist, AM630 [136]. There are various other cells involved in immunity that respond to TRPV1 and TRPA1 activation including bone marrow-derived dendritic cells, where CAPS leads to dendritic cell maturation and an increase in antigen presentation [137].

TRPV1 is expressed, functional and active within cells relevant to inflammation, infection and immunity. It is clear from the studies that TRPV1 at least plays a paradoxical role in inflammation in vivo, for example, exacerbating inflammation in arthritis and yet in experimentally induced sepsis, TRPV1 null mice demonstrate elevated levels of pathological markers in comparison with wild type mice [123]. It cannot be ruled out that this is due to differing effects of neuronal and nonneuronal TRPV1 channels [122].

TRPV1 have been shown to control vascular responses either by the well-established neurogenic response that is mediated by sensory nerves [138] or via a direct effect on vascular tissue $[139,140]$. However, the non-neuronal mechanisms involved in mediating vasodilatation and oedema formation following TRPV1 activation in vivo are unclear. TRPV1 on endothelial cells has been shown to regulate the expression and secretion of endothelial cell-derived CGRP, which affords protective effects on endothelial cells [141]. Furthermore, CGRP is a potent vasodilator [142], and this CGRP may therefore impact upon blood pressure. Indeed, TRPV1 activation on sensory nerves also causes CGRP release, leading to a profound decrease in vascular tone [143]. On the other hand, TRPV1 expressed on vascular smooth muscle appears to cause vasoconstriction $[140,144,145]$. It has also been suggested that CAPS has biphasic effects on the vasculature: at lower concentrations, CAPS (up to 10 $\mathrm{nM}$ ) evokes vasodilation in skin due to sensory nerve activation, whereas higher concentrations (0.1-1 mM) elicit substantial constrictions in skeletal muscle arterioles due to non-neuronal TRPV1 stimulation [140]. It is unclear whether this difference is due to receptor sensitivity or a difference in TRPV1 receptor density in the two tissues. A similar biphasic effect of CAPS has been demonstrated also in meningeal blood vessels [146]. TRPV1 may also play a role in vascular responses during chronic hypoxia where up-regulation of the TRPV1 gene and protein is observed [147]. Chronic hypoxia has been shown to enhance the ability of human pulmonary artery smooth muscle cells to proliferate and to increase resting levels of cytosolic calcium and capacitative calcium entry with both effects being inhibited in a dose-dependent manner by the TRPV1 antagonist, CapZ [147]. These results suggest that TRPV1 on smooth muscle may be a critical pathway or mediator in chronic hypoxia-induced vascular changes [122].

Obesity is one of the most significant health issues in western society due to the morbidity associated with this condition that is increasing in prevalence. Obesity is induced by the hypertrophy of adipocytes and the recruitment of new adipocytes from precursor cells. These processes are dependent on the regulation of adipocyte differentiation. CAPS has been shown to inhibit adipocyte differentiation in vitro by activation of AMP-activated protein kinase [148]. Furthermore, Hsu and Yen [149] have shown that treatment of preadipocytes with CAPS decreases the number of normal adipocytes and increases the number of early apoptotic and late apoptotic cells in a dose-dependent manner. Thus the overall effect of TRPV1 modulation in obesity is stark. Both animal [150] and human [151] data have indicated that the consumption of CAPS- or non-pungent capsiate-containing foods is correlated with a reduced incidence of obesity. Similarly, oral administration of CAPS alone also suppresses body fat accumulation in mice [151], and dietary CAPS can reduce obesity-induced insulin resistance and hepatic steatosis in mice fed a high fat diet [122,152].

In recent years, a role for TRPV1 in thermoregulation has also been identified which may, at least in part, be due to changes in thermogenesis (for review, see $[72,153,154]$ ). For many years, CAPS has been known to cause a centrally mediated hypothermia in mice [126]. In contrast, its intragastric administration enhances thermogenesis and heat diffusion [155]. Similarly, the jejunal administration of non-pungent CAPS analogues was shown to increase energy expenditure via direct activation of TRPV1 located on intestinal extrinsic nerves [156]. Interestingly, some TRPV1 antagonists cause hyperthermia, associated with increased thermogenesis [130] through a peripheral mechanism [131], whilst TRPV1 gene knock down does not affect body temperature in mice [157] and TRPV1 knockout mice exhibit a normal basal body temperature [122,129].

TRPV1 in the alimentary tract has also been implicated in metabolism, hair growth regulation [158], and the development of cancer [159]. 
Consequently, control of the TRPV1 function may have the potential to provide exciting opportunities for therapeutic interventions. Its known functions in both health and disease have been continuously expanding promoting a better understanding of TRPV1.

\section{TRPV1 expression}

TRPV1 channels are mainly expressed on primary sensory neurones. They have been detected in key areas of the pain transduction pathway: on terminals of small- to medium-diameter nociceptors, such as peptidergic and non-peptidergic $\mathrm{C}$ fibres, some $\mathrm{A} \delta$ fibres $[28,79]$; in skin nerve endings, DRGs, nodose ganglia, trigeminal ganglia of the peripheral nervous system, as well as laminae I and II [79] of the dorsal horn of the spinal chord. Projections may also extend into laminae $\mathrm{V}$ and $\mathrm{X}$ [79]. Moreover TRPV1 has been found in different brain regions, such as in dopaminergic neurones of the substantia nigra, hippocampal pyramidal neurones, hypothalamic neurones, neurones in the locus coeruleus, and in various layers of the cortex $[25,160,161]$. The channel is present to a lesser extent in the hippocampus, cortex, olfactory bulb and cerebellum in the CNS $[44,162]$. However, more recently, the use of TRPV1 reporter mice has revolutionized the study of TRPV1 expression, and they would suggest that the expression of this receptor is minimal within a few discrete brain regions, most obviously in the vicinity of the caudal hypothalamus $[122,145]$.

TRPV1 is additionally expressed in discrete spots in the plasma membrane and cytosol of different non-neuronal cells such as the endothelium, immune cells (lymphocytes, dendritic cells and mast cells), keratinocytes, smooth muscle cells and urothelium, thymocytes and macrophages, some of which are known to be involved in inflammation [159]. An increased level of TRPV1 expression has been demonstrated in the sensory fibres of patients with an inflamed oesophagus (gastro-oesophageal reflex disease) or an inflamed bowel (both ulcerative colitis and Crohn's disease), or with chronic breast tenderness and pain [163]. There is likewise an increased TRPV1 expression in the sensory fibres of patients with rectal hypersensitivity and faecal urgency, and this increase is directly correlated with the degree of thermal and mechanical sensitivity [164].

\section{Functionally important amino acid sites and their mutations in the TRPV1}

Emerging data of TRP channel research has elucidated roles for TRP channels in diverse therapeutic areas, and resulted in the identification of numerous potential drug targets beyond TRPV1. Success in finding a viable therapy targeting the TRPV1 channel depends on experimental studies aimed at obtaining detailed knowledge of the channel protein. TRPV1 pharmacology has relied heavily upon information derived from studies of sitedirected mutants of the recombinant channel(s) by the identification of the most appropriate acting sites for potential drug candidates. Figure 1 indicates the mutated residues and the functional changes evoked by them, and also depicts the most important structural properties of TRPV1 (For high resolution figure, see Additional file 1). In order the easier comprehensibility and the more effective usability of the data, a comprehensive table summarizes the information of the mutants at the end of the article (see Table 1).

\section{Mutations affecting agonist action and/or binding CAPS and RTX}

Jordt et al. provided molecular evidence that the mutation of $\mathbf{E 6 0 0}$ caused enhanced sensitivity to CAPS [43]. In the experiments by Jordt et al., replacement of Glu by Gln (E600Q) produced a greater than 10-fold leftward shift in the CAPS dose-response curve, with $\mathrm{EC}_{50}$ values of 520 and $40 \mathrm{nM}$ for wild type and mutant receptors, respectively (Figure 1). Moreover, channels bearing a Lys at this position (E600K) exhibited even higher agonist sensitivity, showing saturated current responses at 50 nM CAPS. Introduction of neutral or positive residues at the E600 site potentiates responses to CAPS, whereas introduction of a residue with lower pKa (E600D) decreases the channel sensitivity to this stimulus [43]. Welch et al. identified E636, D646 and E648 as specific contributors to the CAPS response without affecting the proton or thermal sensitivity. E636Q, D646N and E648Q had a threefold greater sensitivity to CAPS than the wild type TRPV1 channels [165].

A triple mutant (N676F/M677A/L678P) was reported by Kuzhikandathil et al. to disrupt the ability of CAPS and RTX to activate TRPV1, while retaining the ability to respond to protons [166], suggesting that distinct amino acids that are close to or in TM6 control the gating in response to several modes of TRPV1 activation.

Deletion of R114 and E761 in the N- and C-termini can block CAPS-induced currents without affecting TRPV1 activation by heat [16].

F489Y resulted in a rightward shift of the CAPS concentration of half-maximal activation $\left(\mathrm{EC}_{50}\right)$ [167]. Jordt et al. [168] conducted a search for residues involved in the action of CAPS on the basis of the differences between avian TRPV1 and mammalian (rat and human) orthologues [169], and found eight amino acids in the vicinity of TM3 that differ between the two forms, which may account for the species-specific sensitivity to CAPS (F507, Q519, F522, M523, S532, K535, E536 and T550 residues of rTRPV1 corresponding to I515, N527, L530, L531, C540, E543, L544 and A558 of chicken TRPV1, respectively). Exchange of any one of the Q519, F522, M523, S532, K535 or E536 residues for the 


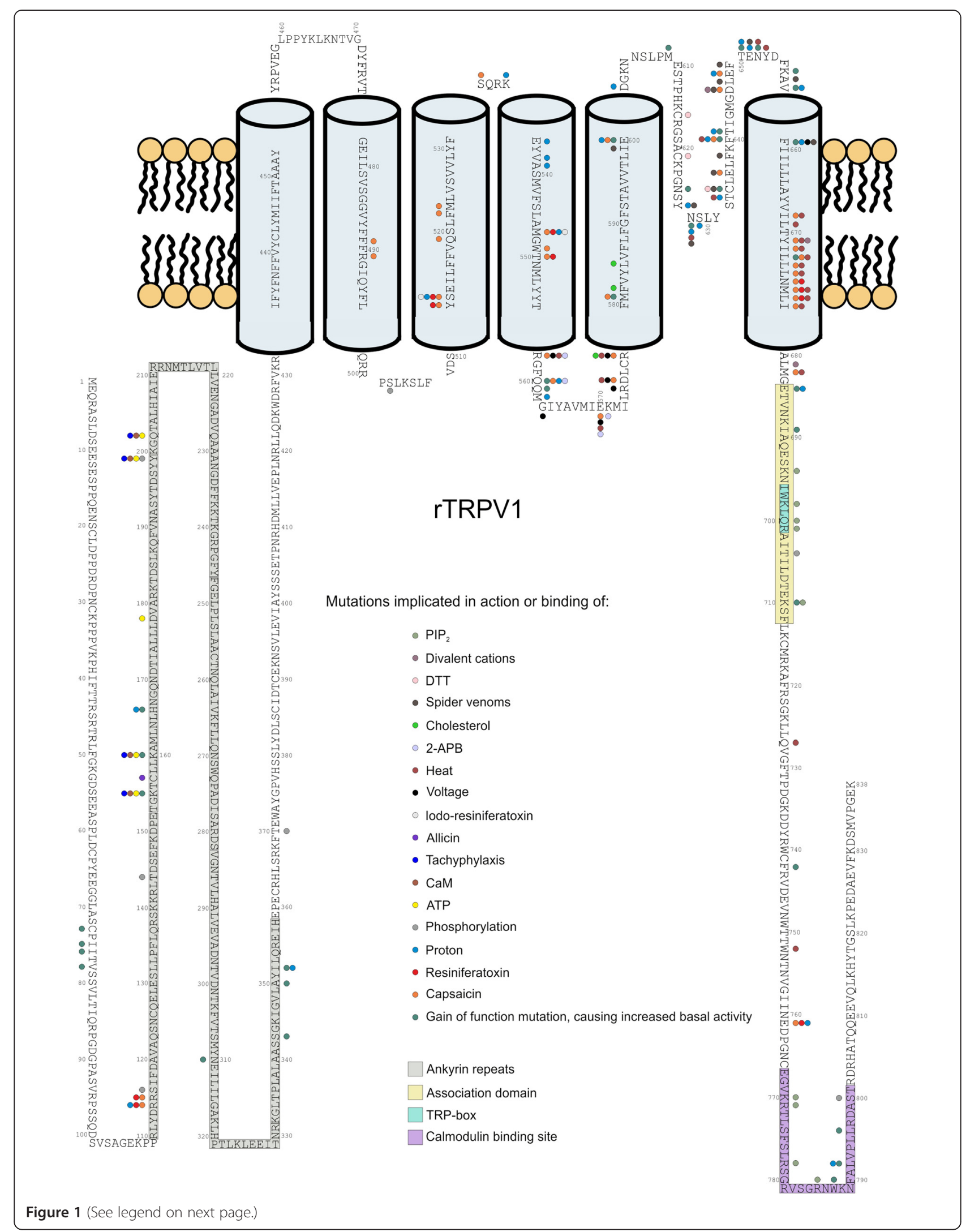


(See figure on previous page.)

Figure 1 Summary of the mutated sites of rTRPV1 The figure summarizes the effect of 112 unique mutated sites along the rTRPV 1 on the function of the channel. Coloured circles indicate the involvement of the given residue in the corresponding process. Coloured boxes show the putative location of some structural elements on the rTRPV1 sequence. Sequence and region information: TRPV1_RAT (O35433) (www.uniprot.org).

chicken counterpart N, L, L, C, E or L, respectively, is sufficinet to ablate the vanilloid sensitivity of rTRPV1. They investigated the TM2-4 regions for sites involved in CAPS, RTX or proton action and observed that substitutions at two positions (R491G in TM2 and S512F in TM3) led to dramatic reductions in both proton- and CAPS-evoked currents. However, the introduction of other mutations at these positions (S512A, S512T or $\mathbf{R} 491 \mathrm{E})$ resulted in a greater preservation of functionality, and in each case a greater reduction in CAPS sensitivity was observed compared to extracellular protons. The mutant S512Y displayed little response to CAPS up to $100 \mu \mathrm{M}$, and no detectable specific binding of RTX. Nevertheless, the proton sensitivity was retained, as were the responses to noxious heat, albeit with a slightly higher thermal threshold $\left(>48^{\circ} \mathrm{C}\right)$ and smaller maximal amplitudes compared to wild type receptors. An extended mutational analysis of the conserved residues adjacent to S512 (D509, S510, Y511, E513 and I514) revealed the most significant effects with the mutant Y511A. Despite lacking any significant CAPS sensitivity, this channel exhibited normal heat- and proton-evoked responses, with a thermal threshold and current amplitudes that were indistinguishable from those of the wild type receptor. In tests of whether the aromatic nature of the residue at position 511 is essential for ligand binding, substitution with a Phe (Y511F) was found to have only moderate effects, whereas substitution with a non-aromatic Cys (Y511C) again eliminated the CAPS sensitivity [168].

Jung et al. [16] identified two regions near Arg114 and Glu761 in the cytosolic tails of TRPV1 that determine ligand binding. Because the Arg114 and Glu761 residues are charged, it is likely that these charges are necessary for vanilloid binding. When positively charged Arg114 was replaced by a neutral amino acid, Ala, the mutant (R114A) elicited a CAPS-induced current comparable with that of the wild type TRPV1. However, when the Arg at 114 was replaced by negatively charged glutamate (R114E), a significant reduction in CAPSinduced current was observed with no apparent specific $\left[{ }^{3} \mathrm{H}\right] \mathrm{RTX}$ binding. Because the adjacent amino acid, R115 is also positively charged, it was also replaced with Asp (R115D). The R115D mutant also abolished the CAPS-sensitive currents, indicating that charge at Arg115 contributes equally to activation by CAPS. When the negatively charged Glu at 761 was changed to Gln, a neutral amino acid retaining a similar structure, the mutant (E761Q) elicited a great reduction in $\mathrm{I}_{\text {cap }}(\sim 98.0 \%$ reduction), and had no specific binding for $\left[{ }^{3} \mathrm{H}\right] \mathrm{RTX}$.
Furthermore, when the Glu at 761 was substituted with positively charged Lys, the mutant (E761K) showed no current response to CAPS or ability to bind $\left[{ }^{3} \mathrm{H}\right] \mathrm{RTX}$. R114E and E761K elicited current responses to heat, but not to acid ( $\mathrm{pH} 5.5$ ).

These results reflect the necessity of the negative charge of Glu at $\mathbf{7 6 1}$ for ligand recognition and the fact that the positive charge at $\mathbf{R 1 1 4}$ determines the ligand binding to the channel, but to a lesser extent than the charge at E761 [16].

Chou et al. [170] showed the residue in position 547 to be a key contributor to RTX binding of TRPV1 by exchanging a single amino acid between the human and rat counterpart. Systematic replacement of the amino acids in the TM1 to TM4 domain of hTRPV1 with the corresponding rTRPV1 residues identified a single conservative substitution of Met for Leu (M547L) at position 547 that accounted for the species difference in RTX binding. The amino acid at this position also affected the potency of the antagonists I-RTX and capsazepine for inhibiting $\left[{ }^{3} \mathrm{H}\right] \mathrm{RTX}$ binding and the agonist response to RTX. The M547A mutation in rTRPV1 reduced RTX affinity to the same degree as M547L ( $\approx 30$-fold). A more radical mutation, M547Q, decreased potency to a smaller degree than either M547A or M547L. In the case of L547A and L547Q mutations in the hTRPV1 no $\left[{ }^{3} \mathrm{H}\right] \mathrm{RTX}$ binding and little channel activity were detected even though protein was seen on western blots. The human L547M mutation has a higher affinity for RTX than wild type rTRPV1, and similarly the rat M547L displayed a lower affinity than wild type hTRPV1 [170]. M547, W549 and T550 in the S4 segment participate in ligand interactions [171,172]. F489 proved to take part in the CAPS activation of the channel [167], probably because of its close proximity to a domain containing mutations R491, Y511, and S512 shown to be implicated in CAPS sensitivity $[168,173]$.

When associated with T704I, S502A was found to lose the ability to be activated by CAPS and lose the ability of vanilloid binding [85,91,174].

Rabbit oTRPV1 can be activated by heat $\left(45^{\circ} \mathrm{C}\right)$ and protons ( $\mathrm{pH} 5$ ), but it is 100-fold less sensitive to vanilloid activation than hTRPV1 or rTRPV1, and oTRPV1-transfected HEK293 cells did not exhibit any specific [ $\left.{ }^{3} \mathrm{H}\right] \mathrm{RTX}$ binding. Gavva et al. [171] constructed a rat-rabbit chimera of TRPV1 by the transfer of TM3 through 4 (S505-T550) from rTRPV1 to oTRPV1. The chimera displayed enhanced sensitivity to vanilloids, similarly to rTRPV1. Additionally, a human-rabbit chimera was created by transferring the 
S505-T550 from hTRPV1 to oTRPV1. The functional analysis again showed that this chimera also gained sensitivity to CAPS, further confirming that the TM3-4 region is responsible for vanilloid sensitivity.

On the basis of the 10 differences found between rTRPV1 and oTRPV1 and the six between hTRPV1 and oTRPV1, Gavva et al. mutated the residues that in rabbit differ from those in both rTRPV1 and hTRPV1 (A505S, A520S, C534R, T540S and I550T). Changing the single residue at 550 in rabbit to the corresponding residue found in rTRPV1 and hTRPV1 (I550T) was sufficient to confer a gain of function for activation by CAPS.

Changing the residues A505S, A520S, C534R and T540S individually or in various combinations did not cause any changes in the responses of oTRPV1 to vanilloids.

For a better understanding of the biophysical requirements at position 550, Gavva et al. explored several polar and hydrophobic substitutions. A gain in CAPS sensitivity was observed when Ser was introduced instead of Thr (I550S), the small non-polar Ala (I550A) resulted in only a partial gain of CAPS sensitivity, while thiol group containing-residue Cys (I550C) resulted in a very small gain in oTRPV1 CAPS sensitivity. Introduction of Tyr (I550Y) with its bulky phenolic side-chain at this position resulted in a complete loss of TRPV1 response to vanilloid, proton or heat activation, although the expression level of this mutant remained comparable to the others. To verify further that the $\mathbf{T 5 5 0}$ found in native rTRPV1 hTRPV1 contributes to the vanilloid sensitivity of TRPV1, the effects of substitution of the natural Thr by the oTRPV1 Ile 550 (T550Y) residue were examined. ${ }^{45} \mathrm{Ca}^{2+}$-uptake experiments revealed a 10-fold loss in sensitivity to CAPS of rTRPV1-T550I, and a 40-fold loss in sensitivity of hTRPV1-T550I.

Gavva et al. [171] confirmed the finding of Jordt and Julius that T511 is critical for vanilloid sensitivity. Both rTRPV1-Y511A and hTRPV1-Y511A had lower vanilloid sensitivity. They tested the CAPS sensitivity of the oTRPV1 double mutant containing I550T (gain of function) and Y511A (loss of function), i.e., oTRPV1-Y511A/ I550T. Compared with oTRPV1-I550T, the reduction in CAPS sensitivity of oTRPV1-Y511A/I550T in the ${ }^{45} \mathrm{Ca}^{2+}$ uptake assay was $>100$-fold. In fact, the magnitude of the loss in CAPS sensitivity by Y511A was greater than the gain seen in I550T. The T550I mutation resulted in the CAPS dose-response curve shifting 10-fold to the right, relative to the control, without reducing RTX sensitivity in the ${ }^{45} \mathrm{Ca}^{2+}$ uptake assay. However, $\left[{ }^{3} \mathrm{H}\right] \mathrm{RTX}$ specific binding was significantly reduced in rTRPV1-T550Itransfected cells. A series of single point mutations were introduced into oTRPV1 (M514I, A525V, T526S, H533Q and L547M) to mimic the residues in rTRPV1, which has been shown to display the highest RTX-binding affinity. Replacement of the oTRPV1 residues at M514I,
A525V, T526S and H533Q individually did not alter the oTRPV1 response to CAPS or RTX. The single residue change L547M in oTRPV1 resulted in a selective gain of 30-fold higher sensitivity to RTX with no apparent change in CAPS sensitivity in ${ }^{45} \mathrm{Ca}^{2+}$-uptake assays. oTRPV1-L547M demonstrated greater sensitivity to RTX, but failed to show any measurable $\left[{ }^{3} \mathrm{H}\right] \mathrm{RTX}$ binding, and it was therefore hypothesized that L547M contributes to RTX sensitivity, but requires additional residues such as T550 to attain the affinity needed for measurable $\left[{ }^{3} \mathrm{H}\right]$ RTX binding above the assay background. A reverse mutation in rTRPV1 (M547L) displayed similar responses to CAPS and RTX in the functional ${ }^{45} \mathrm{Ca}^{2+}$-uptake assay. To test whether oTRPV1 might require both T550 and M547 to attain measurable $\left[{ }^{3} \mathrm{H}\right] \mathrm{RTX}$ binding, the oTRPV1 L547M/I550T double mutant was constructed and its vanilloid sensitivity was examined in functional ${ }^{45} \mathrm{Ca}^{2+}$-uptake and $\left[{ }^{3} \mathrm{H}\right] \mathrm{RTX}$ binding assays. As predicted, oTRPV1L547M/I550T exhibited strong $\left[{ }^{3} \mathrm{H}\right] \mathrm{RTX}$ binding together with only a slight increase in functional sensitivity to CAPS and a somewhat greater increase for RTX. This demonstrates that Met547 and Thr550, as present in native rTRPV1, are required for measurable $\left[{ }^{3} \mathrm{H}\right]$ RTX binding in oTRPV1. oTRPV1-I550T and L547M/I550T resulted in slight changes in sensitivity to $\mathrm{pH}$ 5.5. Gavva et al. hypothesized that Y511, M547 and T550 may be present in the binding pocket and are important molecular determinants for vanilloid sensitivity [171].

Johnson et al. [173] investigated the role of two residues (S512 and M547) identified earlier to be responsible for major species-specific differences in vanilloid activity in the response of the channel to a variety of ligands. Their initial studies confirmed the clear speciesspecific differences in RTX potency described previously by Chou et al. [170]. RTX activated wild type rTRPV1 with a fourfold higher potency than the wild type hTRPV1. Johnson et al. switched the residues at position 547 between the two receptor homologs creating the M547L rat mutant and the L547M human one. L547M produced a significantly more RTX-sensitive channel with the $\mathrm{EC}_{50}$ value comparable with that of the wild type rat receptor. Conversely, when the reverse mutation was made in the rat construct (M547L) a loss of function was observed, although, the change was not significant.

The species-specific differences in CAPS sensitivity were also investigated. CAPS was found to be significantly more potent at the wild type hTRPV1 than at the wild type rTRPV1 channel. When the $\mathbf{5 4 7}$ residue was switched between the rat and the human constructs, the sensitivity to the agonist was again altered. In this instance, this mutation caused a significant decrease in potency in the human mutant (L547M) compared with the human wild type, with an $\mathrm{EC}_{50}$ value comparable with that of the wild type rTRPV1. As for RTX, when the 
reverse mutation was made in the rTRPV1 construct, there was no significant difference [173].

Susankova et al. [175] Ala-scanned the residues Y666G683 containing the most conserved region of the TRP protein family.

Three mutant channels (Y666A, I672A, N676A) showed no CAPS-evoked activity at all. These mutants were also $\mathrm{pH}$ insensitive, they were not activated in the absence of extracellular $\mathrm{Ca}^{2+}$, and they gave very small and nonspecific heat-induced membrane currents. Y666A and N676A possessing no any potentiated currents in response to $47^{\circ} \mathrm{C}$ and $30 \mu \mathrm{M}$ CAPS applied together, proved to be nonfunctional mutants, suggesting that these two residues within the inner-pore region of rTRPV1 are critical for channel functionality.

Co-application CAPS $(30 \mu \mathrm{M})$ and heat stimuli $\left(43^{\circ} \mathrm{C}\right)$ caused efficient potentiation in mutants I672A, L673A, L674A, L678A, and M682A which were functionally silent or only barely responded to CAPS at base temperature. Compared with wild type TRPV1 however, the current densities of the CAPS-induced responses measured at $47^{\circ} \mathrm{C}$ were significantly reduced in: I668A, I672A, L673A, L674A, L675A, and M682A. These mutations but L675, whose heat-activation was unaffected, caused also significantly impaired heat- and CAPS-activation.

Y671A dramatically lowered the CAPS $\mathrm{EC}_{50}$ value in the experiments of Mohapatra et al. [176].

Susankova et al. [175] further studied this mutant and reported that responses to CAPS were not potentiated by heat, but in contrast to the other mutants and the wild type channel, CAPS-evoked responses were consistently inhibited by heating above $30^{\circ} \mathrm{C}$. Susankova et al. reasoned that the loss of potentiation in Y671A might be attributable to changes in agonist sensitivity. When the channels were desensitized by repeated applications of CAPS $(1 \mu \mathrm{M}$ and/or $30 \mu \mathrm{M})$, the heat-induced potentiation reappeared. Y761 might contribute to allosteric coupling between temperature- and CAPS- dependent activation mechanisms.

Susankova et al. evaluated the changes in CAPS responsiveness evoked by Ala mutations by comparing their relative sensitivities at 1 and $30 \mu \mathrm{M}$ CAPS at $47^{\circ} \mathrm{C}$.

An alternating pattern was found with unaltered sensitivity to CAPS in T670A, L675A, G683A, and wild type channels and a reduced but not abolished CAPS sensitivity in mutations I668A, Y671A, I672A, L673A, L678A, and M682A. Interestingly, the mutation of Leu 673 to Ile (L673I) in the experiments of Myers et al. [177] however caused a channel with elevated basal activity and significant cytotoxicity.

To further assess the maximal CAPS-induced responses in the mutants, Susankova et al. compared the inward currents measured at $47^{\circ} \mathrm{C}$ in the absence and presence of a high concentration of CAPS. Except for Y666A, N676A, and I679A, the inward currents were significantly greater in the presence of $30 \mu \mathrm{M}$ CAPS than in its absence. The lack of mutual potentiation between the two stimuli in the former two mutants was caused by their insensitivity to CAPS. Notably, the mutation I679A retained normal sensitivities to both stimuli, although it completely removed their mutual potentiation at $47^{\circ} \mathrm{C}$. In several residues (V667A, T670A, I672A, L673A and L675A), the degree of the CAPSinduced increase in the amplitude of the inward current at $47^{\circ} \mathrm{C}$ was clearly reduced, although these changes did not achieve statistical significance.

Changes induced by individual mutations in the $1 \mu \mathrm{M}$ versus $30 \mu \mathrm{M}$ CAPS-induced current relationships measured at $47^{\circ} \mathrm{C}$ might reflect the changes either in CAPS sensitivity or in the allosteric linkage between CAPS and heat sensor movements and channel opening. Specifically, mutation I679A appeared to cause a decrease in the synergistic interaction of CAPS and heat with the TRPV1 channel.

Susankova et al. denoted that the periodicity observed in the relationships between the maximal activation capacities obtained for 1 and $30 \mu \mathrm{M}$ CAPS at $47^{\circ} \mathrm{C}$ supports the hypothesis that there exists a structural explanation for the gating of the TRPV1 channel by chemical stimuli. The pattern of sensitivity to CAPS (every three to four substitutions) is consistent with an $\alpha$-helical structure contributing to CAPS-induced channel gating. Similar pattern of residues involved in the CAPS sensitivity can be observed in TM3 and TM3-TM4 linker region identified by Jordt and Julius [168]. The repetitive patterns of CAPS sensitive residues apparent in both papers however seem to fit better for a 3.4 residues per turn of the helix than for a 3.6 one. This may further support the finding of Salazar et al. [178] who reported that the TM6 of TRPV1 represent amphipathic helix with 3.4 residues per turn and a $\mathrm{P}(\phi)$ value of $107^{\circ}$ rather than $\alpha$-helix with 3.6 residues per turn and a $\mathrm{P}(\phi)$ value of $100^{\circ}$. Considering the above mentioned findings, all the TM helices of TRPV1 might be regarded to have the same structure [175].

Boukalova et al. [179] found that the E570Q mutation accelerated the rate of activation of the channel. In contrast, a significantly lower rate of activation was observed in mutated rTRPV1 channels containing mutations R557A, M581T, D576R, Q560H, R557K and E570R, indicating contribution of the transduction of the CAPS-binding signal to the opening of the pore. The estimated deactivation time (the time taken for the current to decrease to $50 \%$ of its level before removal of the CAPS) was markedly longer in $\mathbf{R} 557 \mathbf{K}$ as compared with the wild type, but not in $\mathbf{R} 557 \mathrm{~A}$ or $\mathbf{R} 557 \mathrm{~L}$, indicating that the specific side-chain properties of R557, and 
not only a positive charge at this residue, are important for the deactivation gating process. In R557A, R557K, Q560H and M581T, the second response to $1 \mu \mathrm{M}$ CAPS reapplied after an apparent wash-out had a faster onset than in the wild type, suggesting an incomplete deactivation process. The time courses of the CAPS-induced whole-cell currents through R557A, R557L, E570R, D576R, R579A and R576R/R579D closely resembled those of wild type TRPV1. In contrast, R557E/E570R exhibited slower activation and deactivation kinetics. A significantly faster offset of CAPS-dependent responses was detected in E570A and R576R/R579E. The mutations causing similar defects in the voltage-dependence affected the chemical sensitivity of TRPV1 very differently [179].

Mutation studies by Lee et al. [180] and other groups, along with comparisons of TRPV1 variants from species sensitive or insensitive to vanilloids, have identified important residues for ligand binding, such as Tyr511, Met547 and Thr550 [168,170,171].

Lee et al. [180] generated a series of rTRPV1 mutants within the TM3 (Y511A, Y511F) and TM4 (M547L, T550A, T550I, T550S) regions, and performed docking studies with the prototypical agonists, CAPS and RTX, to assess their roles in ligand recognition. Their mutational studies based on the foregoing in silico docking experiments resulted in the discovery that the vanillyl moiety of CAPS oriented towards Y511, while the tail end extended towards M547. The vanillyl moiety formed $\pi-\pi$ stacking and hydrophobic interactions with Y511, and H-bonding with S512. Moreover, the carbonyl group participated in $\mathrm{H}$-bonding interactions with Y511 and L571. Mutation of Tyr in position 511 to Phe (Y511F) had only a slight effect on the activity of CAPS, but its mutation to Ala (Y511A) caused loss of the $\pi-\pi$ stacking and $\mathrm{H}$-bonding capabilities, leading to a sharp decrease in CAPS activity. The mutation of T550I also evoked a significant decrease in CAPS activity, but the influence of the change of Thr to Ala (T550A) or Ser (T550S) was much weaker. This may reflect the bulky side-chain of Ile disturbing the binding of the nonenyl tail of CAPS. Although the hydrophobic nonenyl tail was oriented towards the upper hydrophobic region of the binding site, it did not fully occupy the hydrophobic region of the two shallow hydrophobic areas composed of F543 and M547 because it is linear and too short to reach both areas. These data indicate the relevance of the overall size, shape and/or hydrophobicity of the lipophilic side chain region for binding.

In the case of RTX, the vanillyl moiety appeared to form $\pi-\pi$ stacking with Y511, as did that of CAPS. The importance of Y511 in RTX binding was also confirmed by their mutation study. When Tyr $\mathbf{5 1 1}$ was mutated to Phe (Y511F), the binding affinity of RTX decreased less than fourfold, as the $\pi-\pi$ stacking and hydrophobic interactions of the vanillyl group of RTX were maintained. As compared with the relatively short and linear tail of CAPS, the C13-propenyl group of RTX contributed to the hydrophobic interaction with M547, and its importance in RTX binding was also justified by the mutation studies. When Met was mutated to Ile (M547I), the binding affinity of RTX decreased more than 11-fold. This may be caused by the greater ability of M547 than of Leu to extend to make the hydrophobic interaction with RTX. In addition, the C4-OH group of RTX seemed to fit well with the small side-chain of T550 in addition to $\mathrm{H}$-bonding with the residue. This docking result is in agreement with the mutation data that neither mutated T550S nor T550A caused any binding loss relative to the wild type, while $\mathbf{T} 550$ I led to a drastic decrease (over 20-fold) in RTX-binding affinity. As with CAPS binding, the bulky side-chain of Ile could cause steric interference with the binding of RTX. It was noticeable that the orthophenyl group of RTX underwent hydrophobic interaction with L515. The ultrapotency of RTX might be due to the fact that it could occupy the binding site fully, taking maximum advantage of the multiple possible binding interactions with TRPV1. Since RTX has phenyl rings in both the 4-hydroxy-3methoxyphenyl and lipophilic side chain regions and there are hydrophobic residues at both ends of the binding site, RTX could flip over and achieve a minor binding mode. In this case, the vanillyl moiety would point towards M547 and participate in the hydrophobic interaction. Correspondingly, the orthophenyl group would orient towards Y511. The C20-ester seemed to take part in $\mathrm{H}$-bonding interactions with N551 and the C13-propenyl group formed the hydrophobic interaction with L515 [180].

\section{$A P B$}

Boukalova et al. [179] reported that the inward currents induced by $300 \mu \mathrm{M} 2$-APB were reduced in $\mathbf{R 5 5 7 L}$, R557K, Q560H, E570Q and E570R and most strongly ( $>50$-fold) in K571E, which was normal in all other aspects of TRPV1 activation (Figure 1).

\section{Allicin}

The TRPA1 channel, which is co-expressed in many of the same neurones as TRPV1, has been proposed to be the sole target for the actions of allicin $[56,181,182]$. However, other groups have reported that TRPV1 is also a target for the actions of this compound [57,183-185]. The agonist action of allicin was confirmed by Salazar et al. [186], who further demonstrated that the allicin behaves as a TRPV1 agonist through the covalent modification of a single Cys localized in the N-terminus of the channel at position C157 [187] (Figure 1). 


\section{Mutations affecting heat activation and potentiation}

The heat activation pathway is largely unknown, although the outer pore region, including the turret and the selectivity filter-to-S6 linker, is clearly part of the protein structure participating in the heat-induced conformational rearrangement. Intensive studies of thermo TRP channels have so far indicated numerous channel regions that contribute to temperaturedependent activation. Exchanging the intracellular Ctermini between TRPV1 and the cold-activated TRPM8 channel was found to switch their sensitivity to heat [188]. This result is consistent with the earlier observation that deletion of the last 72 amino acids of the TRPV1 C-terminus influenced channel activation (though in a modality-independent manner) [84]. Furthermore, the intracellular segment between ANK and TM1 was recently proposed to serve as the thermal sensor for TRPV1 $[189,190]$.

Introduction of neutral or positive residues at the E600 site (E600Q and $\mathbf{E 6 0 0 K}$ ) potentiated the responses to heat, whereas the introduction of a residue with lower pKa (E600D) decreased the channel sensitivity to it [43] (Figure 1).

Susankova et al. [175] performed Ala-scanning of the residues Y666-G683. The mutations I668A, L669A, Y671A, I672A, L673A, L674A, M677A, L678A and M682A blunted the heat-induced current responses. To obtain a more complete picture of how the individual mutations affect the heat sensitivity of the TRPV1 channel and to further characterize the specificity of their temperature-induced responses, the temperature threshold for activation and the temperature coefficient $\left(Q_{10}\right)$ from the Arrhenius plots of individual current-temperature relationships were quantified.

The most frequently observed phenotype was a leftward shift in the temperature threshold (V667A, I668A, L669A, L673A, L674A, M677A, L678A and M682A). Seven mutations (T670A, Y671A, I672A, L675A, I679A, L681A and G683A) had thermal thresholds no different from wild type TRPV1. Except for the T670A, L681A, and G683A, the mutations strongly reduced $Q_{10}$ in all mutants tested.

Susankova et al. claimed that average temperaturedependent activation profile with the five peaks separated by four troughs at residues I672-L674, N676, L678, and M682 might correspond an $\alpha$-helical structure, which most likely represents the inner-pore region of the TRPV1 channel. The results of Susankova et al. also provide functional support for the role of the putative inner-pore region in controlling the gating of the vanilloid receptor TRPV1 channel.

L669A and M677A are significantly less sensitive to heat without a significant change of CAPS- or heatpotentiated CAPS currents suggesting that these residues are involved in heat activation of the channel, but not in potentiation by heat. L678A displayed a reduced sensitivity to heat and CAPS with an unaffected heat-potentiated current, suggesting a role of $\mathbf{L 6 7 8}$ in the process of CAPS- and heat- activation, but not in the potentiation mechanism. This finding somewhat contradicts to the results of Kuzhikandathil et al. [166] who demonstrated M677 to affect the ability of CAPS and RTX to activate TRPV1 without changing the channel's response to protons however working on a triple mutant (N676F/M677A/L678P) containing channel [175].

By generating a chimera between the TRPV1 and TRPM8 channels, in which the region V686 to W752 of TRPV1 was replaced by the same C-terminal region of TRPM8 (V982 to W1055), Brauchi et al. [191] identified TRPV1 C-terminal amino acids Q727 and W752 as being the minimum portion able to turn TRPM8 into a heat receptor.

The mutations N628K, N652T and Y653T resulted in TRPV1 channels responding normally to CAPS and $\mathrm{pH}$, but whose heat responses were reduced in amplitude and shifted to higher temperatures. Moreover, the time course of activation of these single point mutants was identical or very similar as compared with wild type TRPV1, suggesting that the desensitization was not strongly altered [167]. A double mutant N652T/Y653T and a triple mutant N628K/N652T/Y653T yielded receptors with CAPS, $2 \mathrm{APB}$ and $\mathrm{pH} \mathrm{EC}_{50}$ values and maximal responses that were indistinguishable from that of wild type TRPV1, but with a further reduction in temperature responses [167]. The triple mutant (N628K/N652T/ Y653T) exhibited altered heat-gating kinetics. Whilst the unitary conductance of the wild type TRPV1 and the triple mutant channel was identical, the triple mutant possessed channel openings of only short $(<1 \mathrm{~ms})$ durations, and the longer ( $10 \mathrm{~ms})$ ones proved to be completely absent. The triple mutant, however, is normally gated by CAPS [167].

The T633A mutant exhibited a weaker response to heat, reaching $\sim 32 \%$ of the $1 \mu \mathrm{M}$ CAPS current. In contrast with the change in peak activity, however, the thermal activation threshold coincided with that of the wild type $\left(\sim 42^{\circ} \mathrm{C}\right)$ [192]. A less severe perturbation to the turret region of the TRPV1 channel by deletion of its first 10 amino acids $\left({ }^{\Delta} \mathbf{G 6 0 3 - S 6 1 2}\right)$ substantially and specifically affected the heat activation but not CAPS activation of the channel [190].

A significantly higher threshold for heat activation was detected by Boukalova et al. [179] for E570A. The Y554F, Y555F, Q561H, E570Q, E570R, K571E, R575A and R579D mutations left the threshold for heat activation unchanged. 


\section{Mutations affecting acid activation and potentiation}

Jordt et al. [43] demonstrated that E600 serves as a fundamental regulatory site for the proton potentiation of vanilloid receptor activity over a physiologically relevant range $(\mathrm{pH} 6-8)$, but not in proton or heat activation. The E600Q mutants retained the ability to be activated by acidic conditions or heat, but differed from the wild type receptor in two significant ways (Figure 1). First, upon heat activation the initial heat stimulus produced a relatively large peak current response that was much closer to the final plateau value than that typically observed with wild type channels. Second, bath acidification failed to potentiate peak currents beyond this steady-state value. Similar results were obtained with oocytes expressing the E600A and E600S mutants. The $\mathrm{pH}$ dependence of thermal activation was related to the side-chain charge of the residue at position 600: heatevoked currents in the E600D mutant were potentiated only when the bath $\mathrm{pH}$ dropped below 6.5. The $\mathbf{E 6 0 0 H}$ mutants, on the other hand, showed continuous potentiation over the entire $\mathrm{pH}$ range tested (9.0 to 5.0), but the extent of potentiation was significantly less than that observed for wild type or E600D channels. For E600Q or other mutants having non-titratable amino acids at this position, the magnitude of the heat-evoked currents was largely independent of the extracellular $\mathrm{pH}$. The D601N and E648Q mutants exhibited a phenotype characterized by reduced proton-evoked responses, with normal CAPS sensitivity. The E648A mutants demonstrated an even greater decrease in proton-activated current amplitudes, whereas the CAPS- or heat-evoked currents did not differ significantly from those of wild type or E648Q channels [43]. This finding is in direct contradiction to the one made by Welch et al., who identified E648 as specific contributor to the CAPS response without affecting the proton or thermal sensitivity [165]. E458Q, D471N, E478Q, E536Q, H614Q, E636Q, D646N, E651Q and D654N mutations were also tested by Jordt et al. [43], but no phenotype was reported in terms of acid activation or potentiation.) E600V caused the complete and specific loss of $\mathrm{pH}$ sensitivity [167].

Deletion of R114 was found by Jung et al. [16] to abolish the sensitivity to acid. When the positively charged Arg at 114 was replaced by a neutral amino acid, Ala, the mutant (R114A) elicited an $\mathrm{I}_{\text {cap }}$ comparable with that of the wild type TRPV1. However, when the Arg at 114 was replaced by negatively charged Glu (R114E), a significant reduction ( $\sim 97 \%$ reduction $)$ in $\mathrm{I}_{\text {cap }}$ was observed with no apparent specific $\left[{ }^{3} \mathrm{H}\right] \mathrm{RTX}$ binding.

Sutton et al. reported that the $\mathbf{S 5 1 2 Y}$ mutant caused a small but significant decrease in the ability of protons to gate the TRPV1 channel [193].
A mutation of hTRPV1-L547M by Johnson et al. [173] caused a decrease in the potency of protons, but no increase was seen when the reverse switch was made in

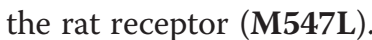

E651 was found to be important for $\mathrm{pH}$ activation [192]. Substitution of the residue T633 by Ala abrogated low pH-activated currents, but the T633A mutant exhibited normal CAPS responses, including rapid activation kinetics and large steady-state currents. Furthermore, the potentiation by low $\mathrm{pH}$ was also retained, despite the loss of the low $\mathrm{pH}$ sensitivity for direct activation. Conserved residues on the $\mathrm{N}$-terminal end of the pore helix were also mutated by Ryu et al., i.e., Y627A and S629A. Both mutants were functional and produced relatively normal responses to CAPS when applied either alone or in combination with mildly acidic $\mathrm{pH}$. The mutants were also activated by low pH directly, albeit with a slightly smaller maximal current than their wild type counterparts. The data suggest that these residues may contribute to, but do not play a pivotal role in the proton activation of TRPV1 as T633 does [192]. In the wild type counterpart, pH 5.5 evoked long bursts of activity, in which the openings were separated by brief closures. The T633A mutant instead showed rare spike-like openings. The mutation drastically slowed the opening rate at low $\mathrm{pH}$. The significant shortening of the open time suggests that the mutation destabilizes the open conformation of the channel. T633 was systematically mutated to others, including $\mathrm{Y}, \mathrm{R}, \mathrm{Q}, \mathrm{N}, \mathrm{L}$, $\mathrm{K}, \mathrm{E}, \mathrm{D}, \mathrm{V}, \mathrm{S}$ and $\mathrm{A}$, which span both polarity and size. Substitutions with polar residues such as Q, N and Y or the charged residues $\mathrm{R}, \mathrm{K}, \mathrm{E}$ and $\mathrm{D}$ all resulted in nonfunctional channels. The T633S mutation was functional, but with a significant reduction in low $\mathrm{pH}$ current and a slow activation by CAPS. However, the T633V mutation preserved the wild type responses in all aspects. On substitution with Leu, containing a larger hydrophobic sidechain, the channel became non-functional. Together, these results suggested that T633 is involved in functional interactions in a compact hydrophobic environment. The size of the side-chain at this position is crucial. Replacing Thr by Ala, a smaller side-chain, was able to preserve the CAPS response while abrogating the low $\mathrm{pH}$ activation; a larger side-chain substitution at this position, on the other hand, became deleterious [192]. The K535E, E536W, V538L and A539P residues were clustered around the centre of the loop, and the mutations appeared to impact predominantly the proton responses. V538L resulted in no detectable current at $\mathrm{pH} 5.5$, while retaining $>93 \%$ of the wild type peak CAPS response. The CAPS response of E536W was also reduced; however, this mutation, as with K535E and A539P, involved substantial changes in the side-chain property. Such substitutions could produce non-local perturbations on the channel structure and consequently non-specific phenotype changes. A common 
feature of all these mutations is the significant, consistent reduction of the low $\mathrm{pH}$ current, suggesting that the region plays an important role in proton activation. S532M, Q533E, S540L and M541L exerted little effect on either CAPS or low $\mathrm{pH}$ responses. The CAPS activation and its potentiation by low $\mathrm{pH}$ were not altered by the $\mathbf{V} 538 \mathrm{~L}$, E536W, K535E or A539P mutations at the macroscopic level. V538L displayed a marked (>90\% suppression) reduction in the maximal activity elicited by $\mathrm{pH} 4.5$. Also unlike T633A, which exhibited no measurable $\mathrm{pH}$ current over the entire $\mathrm{pH}$ range, $\mathbf{V 5 3 8} \mathrm{L}$ furnished a titration curve with a consistently increasing trend as the $\mathrm{pH}$ was lowered. It appears that the mutation weakened, but did not disrupt the $\mathrm{pH}$ gating completely. The V538L mutant also exhibited a robust heat response.

The function of the channel appeared to be quite sensitive to perturbations at position 538 (V538L, V538A, V538G, V538I, V538T). Even the relatively conservative substitution with Ala abrogated the low $\mathrm{pH}$ currents and also reduced the CAPS activity. Further reduction of the size of the side-chain with a substitution by Gly resulted in non-functional channels [192].

In the experiments by Myers et al. [177], wild type TRPV1 responded strongly to CAPS but displayed negligible current under basal conditions or in response to $\mathrm{pH}$ 6.4, which is at the threshold concentration required for proton-evoked activation at room temperature. In contrast, eight mutants (H166R, I352N, I352T, Q560R, M562D, E684G, E684V, L792P), displayed a significant response to $\mathrm{pH}$ 6.4, although no basal current was detected at $\mathrm{pH}$ 7.4 Mammalian cell patch-clamp experiments by Myers et al. demonstrated that F640L displayed a strong basal channel activity and substantial toxicity when expressed in HEK293 cells. Whereas the wild type channel was potentiated by exposure to $\mathrm{pH}$ 6.2, the F640L current was completely unaffected under these conditions. Addition of CAPS to F640L-expressing cells led to a marked increase in current, demonstrating that F640L channels are not maximally open in the basal state. Higher doses of protons could activate the mutant channel illustrating that while the mutant has lost the ability to be potentiated within a certain $\mathrm{pH}$ range, its proton activation has not been completely ablated. Weakly alkaline solution ( $\mathrm{pH}$ 8.2) failed to reduce the F640L-mediated basal current. N628D and V658A showed a potentiation effect under moderately acidic conditions. Furthermore T641S and T650S mutants displayed large constitutive channel activation with relative insensitivity to $\mathrm{pH} 6.4$ [177].

Wang et al. reported that the first four TMs (TM1-4) of TRPV1 dictate whether the activity of a fully CAPSbound receptor can be further enhanced by protons, and a glutamate residue (E536) in the linker between TM3 and TM4 of hTRPV1 is critical in the modulation by protons and in the further stimulation of fully liganded TRPV1 [75,194].

Aneiros et al. [195] replaced amino acid F660 in hTRPV1 (corresponding to $\mathbf{F 6 5 9}$ in rTRPV1) with a variety of different amino acids (A, C, E, H, I, K, L, S, T, V, $\mathrm{W}, \mathrm{Y}$ ) to determine the side-chain contribution to the proton activation of TRPV1. Proton activation was ablated by all amino acid replacements with the exceptions of F660Y and F660W, the two alternative non-basic aromatic amino acids besides Phe. Replacing Phe with His $(\mathrm{F} 660 \mathrm{H})$, which contains a basic aromatic ring (imidazole), or non-aromatic amino acids caused complete loss of proton activation. However, F660Y demonstrated a reduced sensitivity to proton activation as compared with wild type TRPV1. Although less pronounced, the maximum effect values at $1 \mu \mathrm{M}$ CAPS were also reduced relative to the wild type, while the CAPS $\mathrm{EC}_{50}$ values at $\mathrm{pH} 7.4$ were comparable. $\mathrm{Ca}^{2+}$ flux and whole-cell patch-clamp experiments using HEK293 cells transiently expressing TRPV1 mutants or wild type TRPV1 demonstrated a complete lack of activation of the mutant F660S by protons. In contrast, F660S maintained responsiveness to CAPS. TRPV1 mutant F660S ablated proton activation, but not CAPS or heat activation. F660A neither significantly inhibited nor significantly potentiated CAPS responses in the presence of protons. F660W showed a reduction in sensitivity to proton activation as well as CAPS activation similarly to F660Y. These data suggest that a non-basic aromatic amino acid at position 660 is essential for proton activation. A nonaromatic amino acid or His at position 660 seems to be tolerated for the channel to be functional in the CAPS activation mode; a non-basic aromatic side-chain, however, appears to be required to maintain activation by protons. The loss of activation by protons when F660 is replaced with a charged amino acid and the absence of a titration phenotype suggest that Phe is critical for the transduction of proton-mediated gating rather than voltage or proton sensing. Aneiros et al. concluded that the proton activation and potentiation of TRPV1 are both voltage-dependent and that amino acid $\mathbf{6 6 0}$ is the key residue regulating the proton-mediated gating of hTRPV1 [195].

\section{Mutations affecting voltage sensing}

Susankova et al. [175] also checked the Ala-scaned region of Y666-G683 for mutants disturbing the voltage sensor function of the channel. To compare the effects of mutations on voltage-dependent activation, Susankova et al. used a voltage step protocol from -140 to $+140 \mathrm{mV}$ (increment, $+20 \mathrm{mV}$ ) at $25^{\circ} \mathrm{C}$ and normalized the resulting current-voltage relationships at $+60 \mathrm{mV}$ for each cell.

Except for the T670A, Y671A and M677A, the Ala mutations led to a rightward shift of the activation curve 
and a concomitant decrease in the equivalent charge $z$, reflecting a decrease in channel activity at more negative holding potentials (Figure 1).

These data indicate that most of the Ala mutations modulate the gating of the TRPV1 by shifting the voltage dependence toward more positive membrane potentials. Temperature- and voltage-dependent mechanisms underlying the TRPV1 channel activation do not need to be strictly coupled [175].

Voets et al. demonstrated the roles of K571, R575 and R579 in voltage sensing using charge-neutralizing mutations in TM4 and the TM4-TM5 linker of human TRPM8 [172,196].

In the experiments of Boukalova et al. [179], the halfmaximal activation voltage $\left(\mathrm{V}_{1 / 2}\right)$ of wild type TRPV1 was $154 \pm 4 \mathrm{mV}$, and $\mathrm{V}_{1 / 2}$ was shifted towards less depolarizing voltages for R557K $(97.1 \pm 4 \mathrm{mV})$, G563S $(78 \pm 2 \mathrm{mV})$, and M581T $(122 \pm 11 \mathrm{mV})$. Mutations Y554A, Y555S, E570L, R557E and R579E led to a complete loss of function, but three charge-swapping double mutants (R557E/ E570R, D576R/R579E and D576R/R579D) exhibited measurable voltage-dependent activity, indicating a partial recovery of the functionality of the R557E and R579E mutant channels. To reveal the voltage-independent component of TRPV1 gating, Boukalova et al. [179] quantified $\mathrm{V}_{1 / 2}$ and the percentage of the voltageindependent component of gating from currents obtained in the presence of $10 \mu \mathrm{M}$ CAPS. Significant changes in the apparent gating valence were detected in E570R and D576R/R579D, indicating that the S4-S5 linker may increase its contribution to voltage sensing when CAPS is present. R557A, R557L, D576N and D576R, which were only weakly voltagedependent under control conditions, became as voltage-sensitive as wild type TRPV1 in the presence of CAPS, suggesting a preserved or even increased allosteric effect between these two stimuli. Relative to wild type TRPV1, the percentage of the voltageindependent component of CAPS-induced gating was found to be strongly reduced in R557A, R557L, E570A, R579A, R579D, R557E/E570R and D576R/ R579E. In contrast, this component was predominant in E570Q and E570R. G563S possesses an enhanced voltage-dependent activity; inward currents induced by $1 \mu \mathrm{M}$ CAPS exhibited slow activation kinetics and an incomplete deactivation that was fully blocked by $1 \mu \mathrm{M}$ RuRed. G563S was not responsive to a temperature ramp (from $25^{\circ} \mathrm{C}$ to $48^{\circ} \mathrm{C}$ ) and was only weakly sensitive to $300 \mu \mathrm{M} 2$-APB. These data suggest that the mutation G563S stabilizes the open conformation of the channel and thus G563 in TRPV1 could play an analogous role in channel gating as in TRPV3 [179].

The F660S mutant in hTRPV1 (corresponding to F659S in rTRPV1) was shown by Aneiros et al. to lack both voltage-dependent proton activation and potentiation, whereas activation by heat or CAPS was preserved [194,195].

\section{Mutations affecting antagonist or channel blocker action/ binding \\ I-RTX}

S512 and M547 were tested by Johnson et al. [173] for their potential involvement in I-RTX action.

I-RTX shows species-specific activity on TRPV1, as well. The effect of the $\mathbf{5 4 7}$ residue on the ability of IRTX to antagonize the response of TRPV1 to $500 \mathrm{nM}$ CAPS was also challenged. As for RTX, the antagonist I-RTX was found to be significantly more potent at the rat receptor versus human receptor. After substitution of the rat-specific Met into the human construct (L547M), I-RTX gained functional potency, although the converse change (M547L) showed little effect (Figure 1). Introduction of the Met residue thus enables the human receptor to interact more effectively with both agonist and antagonist alike in a manner that is not matched by Leu.

S512Y was found to convert I-RTX from an antagonist to an agonist with nanomolar potency, albeit with much lower efficacy than its counterpart (RTX) for the wild type channel. Other agonists such as CAPS or acidification with $\mathrm{pH} 5.8$ was shown to enhance the agonist potency of I-RTX, producing a 20 -fold decrease in the $\mathrm{EC}_{50}$ value [173].

\section{RuRed}

D646N was reported by Garcia-Martinez et al. to decrease the efficacy of RuRed to block the channel by 10fold [197] (Figure 1).

\section{Mutations affecting spider venoms action/binding}

Venoms from spiders, snakes, scorpions and cone snails can cause burning pain. Small peptides, named vanillotoxins (VaTx) and "double-knot" toxin (DkTx) were indentified as TRPV1 agonists from the venoms of the spiders Psalmopeous cambridgei and Ornithoctonus huwena, respectively. Alanin scanning of the region S592-A665 revealed three sites (I599A, F649A, and F659A) where alanin substitutions caused reduced toxin responses (Figure 1). A657P and A657W also showed loss of toxin sensitivity. Xenopus laevis xTRPV1 also contains Pro at the extracellular boundary of the S6 domain, corresponding to amino acid A657 of rTRPV1, and is insensitive to VaTx or DkTx, but responds to CAPS and low $\mathrm{pH}$. The reciprocal mutant (P663A) conferred toxin responsiveness of the frog TRPV1. The quadruple mutant (I599A/ 
F649A/A657P/F659A) completely eliminated toxin sensitivity $[198,199]$.

The venom from the spider Agelenopsis aperta, a North American funnel web spider, contains potent inhibitors of TRPV1. Two acylpolyamine toxins, AG489 and AG505, inhibit TRPV1 from the extracellular side of the membrane [200]. To identify mutations that alter these toxin affinity, Kitaguchi and Swartz [200] Trp scanned the TM5-TM6 linker region from Y627 to E651, mutating 25 consecutive residues to Trp. Of these mutants, 15 resulted in channel expression that could readily be studied by using electrophysiological techniques, whereas 10 produced little or no CAPS-activated current and were not studied further. One residue in this region (D646) was also mutated to Asn. The D646W mutant did not yield functional channel. N628W, E636W, D646N and E651W dramatically decreased toxin affinity. Mutations of Y627W , C634W and to a lesser extent F638W, L647W and F649W enhanced the sensitivity to the toxin [200]. According to these results and previous studies on polyamine inhibitors of cation channels, AG489 seemed to be a pore blocker.

\section{Sites of action of negative or positive modulators}

A number of studies have demonstrated that the cytoplasmic regions of TRP channels bind agonists and regulatory molecules such as ATP, CaM and PIP2 $[14,95,107,201-204]$.

\section{ATP}

Kwak et al. [205] found that D178N substitution abolished the ATP-mediated upregulation of TRPV1. Mutations generated by Lishko et al. [14], K155A and K160A, and the double mutation Y199A/Q202A impaired the TRPV1-ARD interaction with ATP. TRPV1 channels with mutations in the ATP-binding site (K155A, K160A, or Y199A/Q202A) showed little tachyphylaxis, even in the absence of ATP, while the two negative control mutants (R181A and K265A) had essentially wild type behaviour (Figure 1). The lack of tachyphylaxis shown by the TRPV1 mutants was not due to an impaired CAPS sensitivity; in fact, the mutant channels were slightly more sensitive to CAPS than the wild type channel $[14,46]$.

\section{$\mathrm{Ca}^{2+} / \mathrm{CAM}$}

$\mathrm{Ca}^{2+} / \mathrm{CaM}$ has been reported to bind to peptides from the N-terminal region of TRPV1, and that the residues 189-221 are crucial determinants for binding [107]. Grycova et al. [206] found that the CaM-binding site overlapped with the PIP2-binding site in the C-terminal distal region (L777-S820) and that PIP2 interacted with the proximal region (I688-K718) of the TRPV1 Cterminal (Figure 1).
Lishko et al. [14] found that the TRPV1-ARD mutants K155A and K160A, which no longer bind ATP, did not interact with $\mathrm{CaM}$ in size exclusion chromatography, emphasizing that the binding surface on TRPV1-ARD is at least partially shared by both ligands.

The TRPV1-ARD Y199A/Q202A mutant, where residues important for interactions with the adenine moiety of ATP were mutated, formed a weaker complex with $\mathrm{CaM}$ that eluted earlier than the complex with wild type TRPV1-ARD, still had a 1:1 stoichiometric ratio, suggesting that the different elution properties may be due to an altered conformation or binding constant, or higher-order (e.g., 2:2) complex [14].

\section{PIP2}

PIP2 has been shown to physically interact with a Cterminal fragment of TRPV1 [203]. In the experiments of Brauchi et al. [191] the mutation of the positively charged R701 and K710 to Ala strongly affected the PIP2-dependent activation, shifting the dose-response curves to the right along the concentration axis [191] (Figure 1).

Grycova et al. [206] showed that two different PIP2binding sites on the C-terminus L777-S820 and the Nterminus F189-V221 overlapped with the CaM-binding sites, and the third PIP2-binding site K688-K718 occupied the TRP domain on the C-terminus, a highly conserved sequence among the members of the TRP ion channel family. The presence of PIP2 was reported to prevent the interaction of the distal region of the $\mathrm{C}$ terminus with CaM, which could play an important role in the regulation of TRPV1. To identify the residues important for the binding of PIP2 to TRPV1-C-terminus, a set of point mutations was generated by Grycova et al., involving the single substitutions R778A and R781A, the double substitutions K770A/R785A, R771A/R781A and R771A/R778A and the triple substitutions K770A/ R778A/R785A and K770A/R781A/R785A. The most striking effect was the total loss of binding affinity observed for the single mutant R778A, the double mutant R771A/R778A and the triple mutant K770A/R778A/ R785A. Moreover, the K770A/R785A and R771A/ R781A mutations decreased the binding affinity. The K694A/K698A/K710A triple mutant seemed to completely lose its ability to bind PIP2. Ala substitutions of the additional candidate residues in the highly conserved QRA region Q700A/R701A significantly attenuated its binding affinity for PIP2. These data show that the TRPV1 C-terminal proximal region (K688-K718) binds PIP2 directly with a high affinity and suggest that basic residues play a crucial role in the binding.

The steady-state anisotropy measurements by Grycova et al. confirmed that the region denoted as a CaM interaction site F189-V221 binds PIP2 with high affinity. On 
the basis of their molecular model of the PIP2 interacting with the TRPV1 C-terminal distal region, Grycova et al. suggested that the phosphate head groups of PIP2 form polar interactions with positively charged Arg residues R778, R781, R785. PIP2 thus occupies the CaM binding groove containing R771, R778, R781, R785 described previously [201]. Residues R778 and R781 were found to have key role in the binding of PIP2. Further combinations of Ala substitutions revealed that the TRPV1-CT distal region participates in PIP2 binding through a cluster of basic residues: the double and triple substitutions of R771A/R778A and K770A/R778A/ R785A avoided PIP2 binding totally, and the K770A/ R785A and R771A/R781A mutations suppressed this interaction partially. Site-directed mutation of R701 Arg reduced the binding affinity for PIP2. The triple substitution at positions $\mathrm{K694A} / \mathrm{K} 698 \mathrm{~A} / \mathrm{K} 710 \mathrm{~A}$ had the most pronounced effect, preventing PIP2 completely from binding to this region. The regions F189-V221 within the N-terminus and K688-K718 and L777-S820 within the C-terminus are involved in PIP2 binding. Interestingly, the F189-V221 and L777-S820 regions overlap with the CaM-binding sites, suggesting that $\mathrm{CaM}$ and PIP2 compete for the same binding site, which might have implications for regulation of the channel function. R778A was found to have the key role in the interaction. This single mutation leads to a total loss of binding affinity of the distal C-terminal region [206].

\section{Reducing agents}

DTT, an agent that maintains the -SH groups of Cys in a reduced state, has been reported to facilitate membrane currents through TRPV1 when applied from the extracellular face of the channel, by interacting with the residues at positions C616, C621 and C634 in the loop between the fifth and sixth transmembranal domains [207] (Figure 1).

Site-directed mutagenesis experiments in the pore loop have identified C621 as the residue responsible for the extracellular modulation of TRPV1 by reducing agents [112]. Mutations C616G and C634G did not affect DDT potentiation at $45^{\circ} \mathrm{C}$, but $\mathbf{C 6 2 1 G}$ and the triple mutant C616G/C621G/C634G significantly reduced DDT potentiation without having any effect on the CAPS, heat or voltage gating of the channel $[78,112]$.

\section{Cholesterol}

Using measurements of CAPS-activated currents in excised patches from TRPV1-expressing HEK293 cells, Picazo-Juárez et al. [208] showed that enrichment with cholesterol, but not its diastereoisomer epicholesterol, markedly decreased wild type rTRPV1 currents in the presence of CAPS, elevated temperature or voltage.
Substitutions in the S5 helix by Picazo-Juárez et al. [208], R579D and F582Q, decreased the cholesterol response and L585I was insensitive to cholesterol addition (Figure 1). Two hTRPV1 variants, with different amino acids at position 585, displayed different responses to cholesterol, with hTRPV1-I585 being insensitive to this molecule. However, hTRPV1-L585 was inhibited by cholesterol addition similarly to rTRPV1 with the same S5 sequence (containing L585). In the absence of CAPS, cholesterol enrichment also inhibited the TRPV1 currents induced by elevated temperature and voltage.

The amino acids in positions K571, R575 and R579 were confirmed to be involved in TRPV1-lipid interactions $[172,191]$.

\section{Mutations of phosphorylation sites}

Phosphorylation by PKC, which potentiates CAPS, acid, and thermal responses in TRPV1 channels, occurs at two target Ser residues (S502 and S800) $[78,85,209]$ (Figure 1). Residues located in the N-terminus of TRPV1 (S116 and T370) are phosphorylated by PKA and have been implicated in desensitization $[85,176,210]$ whereas residues T144, T370 and $\mathbf{S 5 0 2}$ have been implicated in the sensitization of heat-evoked TRPV1 responses when phosphorylated by PKA [78,83]. Phorbol 12-myristate 13-acetate (PMA), a PKC-activating phorbol, was observed to decrease the binding of $\left.{ }^{3} \mathrm{H}\right] \mathrm{RTX}$ to TRPV1 [115] through interaction with Y704 in the C-terminus $[46,85]$.

The site-directed mutation of residue S116A performed by Wang et al. [90] was reported to block both the phosphorylation of rTRPV1 by $\mathrm{PKC} \mu$ and the enhancement by $\mathrm{PKC} \mu$ of the response of rTRPV1 to CAPS. Ser116 is also a major phosphorylation site in TRPV1 for PKA, and this site has been shown to be involved in TRPV1 desensitization [116].

Numazaki et al. [174] observed that, when S502 and S800 residues were replaced with Ala, the TRPV1 activity induced by CAPS, protons or heat was eliminated [78]. S502A was found to significantly reduce PMA enhancement of CAPS-evoked currents, but had no effect on direct activation by PMA [91].

CaMKII regulates TRPV1 activity through the phosphorylation of two residues: S502 and T704 [46,91].

Phe mutations of the hTRPV1 Y195, Y199, Y375, Y383 and Y402 did not diminish Src kinase dependent phosphorylation. But when Y200 (corresponding to Y199 in rTRPV1) was mutated, Src-dependent, NGF-induced Tyr phosphorylation was completely abolished [211].

A glycosylation site (N604) was identified by Wirkner et al. [172,212].

\section{Mutations affecting divalent cations}

Site-specific analysis has shown that substitutions of D646 or Y671 in the pore domain can reduce the permeability 
of divalent cations $[176,197]$ (Figure 1). This cation selectivity is dynamic, not static, and can vary depending on the stimulus duration or agonist concentration. Activation can alter the $\mathrm{Ca}^{2+}$ permeability and pore diameter of TRPV1 to allow influx of larger cations. This change in permeability is mediated by amino acid residues in TM6. Within this domain, L681 can regulate the permeability of large cations, while Y671 gates the access of smaller cations $[169,178]$. Our group discovered a blocking effect of divalent heavy metal cations and especially of $\mathrm{Co}^{2+}$ on rTRPV1 [213]. The effects of the cations were evaluated in rTRPV1 containing mutations reported earlier in context of proton activation and tarantula toxin effect. The $\mathrm{Co}^{2+}$ sensitivity was slightly reduced in the D646N mutant. The Y627W, N628W and E651W mutants displayed little or no difference as compared with the wild type channel [213].

\section{Mutations of structural involvement}

Deletion studies have shown that the C-terminal TRP domain (E684-R721) regulates the formation of functional channel tetramers [214]. Removal of this region prevents the oligomerization into stable TRPV1 heteromers [169].

\section{Mutations causing heightened base activity}

Constitutively active TRPV1 mutants might harbor deficits in some aspect of channel activation, and a comprehensive list of such mutations could provide valuable information about the location of the channel gate.

Jordt et al. [43] showed that HEK293 cells expressing E600Q TRPV1 channels showed markedly reduced viability. Replacement of this Glu residue with Gln (E600Q) or a positively charged amino acid (E600K) resulted in a significant level of cell death in HEK293 cells expressing these mutant channels, over their heightened activity under normal culture conditions, whereas substitution with an acidic residue (E600D) was not deleterious (Figure 1). This observation suggested that a decrease in negative charge at the $\mathbf{E 6 0 0}$ site favours channel activation. The E600K mutant showed a most dramatic sensitization phenotype. These channels were already activated at temperature thresholds $\left(30-32^{\circ}\right.$ C) well below normal $\left(43^{\circ} \mathrm{C}\right)$, resembling the heat sensitivity of wild type channels at $\mathrm{pH} 6.3$ [43].

By genetic screening of a randomly generated population of TRPV1 mutants, Myers et al. [177] demonstrated that mutations within the pore helix domain dramatically increased basal channel activity and responsiveness to chemical and thermal stimuli. The screening for gain of function mutations revealed a total of 30 unique mutations at 25 amino acid positions: C73S, K160E, S343R, A350T, Q561R, M581T, M609T, F640L,
N652D, L673I, E684G, E684V, K710R, F742S, W787R and L796P caused strong toxicity when expressed in Saccharomyces cerevisiae, whereas other gain of function mutations I75F, I76T, V78G, K155E, H166R, N310D, S343G, I352N, I352T, Q560R, M609V, I689V, L792P and $\mathbf{L 7 9 6 V}$ elicited weak toxicity to the cells.

Some mutants displayed large basal currents at $\mathrm{pH}$ 7.4, which could be blocked by RuRed. The authors classified mutants as constitutively active when the ratio of the basal inward currents and the CAPS-elicited currents exceeded $0.15\left(\mathrm{I}_{\text {basal }} / \mathrm{I}_{\text {cap }} \geq 15 \%\right)$. The mutants K155E, K160E, M581T and F640L achieved a rank constitutively active.

F640L displayed the strongest basal channel activation, and conferred substantial toxicity when expressed in HEK293 cells, characterized by necrotic morphology similar to that observed in cells expressing wild type TRPV1 after prolonged exposure to CAPS. Inclusion of RuRed $(3 \mathrm{mM})$ in the culture medium significantly attenuated the death of $\mathbf{F 6 4 0 L}$-expressing cells.

Inside-out patches from the F640L mutant displayed large basal currents with a substantial inward component but CAPS at saturating concentrations elicited currents of similar magnitude to those evoked in patches containing wild type channels.

Myers et al. found no significant difference in either the single-channel conductance or the relative permeabilities for $\mathrm{Na}^{+}, \mathrm{K}^{+}$, and $\mathrm{Ca}^{2+}$ ions when comparing wild type and F640L mutant channels, showing that the F640L mutation affects gating rather than permeation properties. Consistent with a hypersensitive gating mechanism, F640L mutant displayed a 35-fold leftward shift in the CAPS dose-response curve compared to the wild type receptor, the basal current however, was suppressed by CapZ demonstrating that the high constitutive activity is not due to an inability of the channel to close. Consequently, the gating machinery seems to remain intact in the F640L mutant, but the equilibrium appears to be shifted to favor the open state. F640L mutation enhances sensitivity to heat and CAPS by shifting the stimulus- response relationships of the channel leftward while also decreasing apparent cooperativity of gating.

To fully explore the structural requirements at position F640 a codon randomization was performed. Most substitutions at this position, particularly those of a hydrophilic nature, weakened or abolished channel activity. F640K, F640Q, F640S, F640H, F640Y weakly, whilst F640C, F640E, F640G, F640N, F640R, F640D, F640P strongly decreased channel function. Furthermore, F640A and F640T represented an intermediate phenotype between wild type and weak loss of function. In contrast, several hydrophobic amino acids supported wild type functionality (F640M, F640V, F640W), except 
for Leu and Ile, which produced constitutively active channels (F640L, F640I). Thus this codon randomization illustrated that most hydrophobic substitutions at F640 produced functional channels, whereas two small hydrophobic residues supported constitutive channel activity, suggesting that F640 is buried in a non-polar environment. Myers et al. uncovered nine additional substitutions conferring a toxic phenotype in yeast (N625D, N628D, C634S, T641S, T650S, K656E, K656Q, V658A and F659Y). These mutants were unable to grow on replica plates containing CAPS but no RuRed. Of these, two (T641S and T650S) showed high basal activity. Interestingly, T641S (and, to a lesser extent, T650S) mutants displayed large constitutive channel activation with relative insensitivity to $\mathrm{pH} 6.4$ [177].

\section{Mutations having deleterious effects on channel function} The E610Q mutants exhibited relatively small responses to any stimuli (CAPS, heat or $\mathrm{pH}$ ), suggesting that this substitution had deleterious effects on the channel function at large [43]. The function of the channel appeared quite sensitive to perturbations at the position V538 (Figure 1). Substitution with Gly (V538G) resulted in non-functional channels [192]. Susankova et al. [175] mutated and examined the residues Y666-G683 of TRPV1. Y666A and N676A showed no CAPS-, pH- or heat-evoked activity and exhibited no currents in response to $47^{\circ} \mathrm{C}$ and $30 \mu \mathrm{M}$ CAPS applied together. They were determined to be non-functional mutants, suggesting that these two residues within the inner-pore region of rTRPV1 are critical for channel functionality. Boukalova et al. [179] identified mutations Y554A, Y555S and E570L and two charge-reversing mutations, R557E and R579E, that led to a complete loss of function. In these mutants, $10 \mu \mathrm{M}$ CAPS neither induced measurable currents at a holding potential of $-70 \mathrm{mV}$, nor affected voltage-dependent (up to $+200 \mathrm{mV}$ ) or heat-dependent currents (up to $48^{\circ} \mathrm{C}$ ). The Y554F and Y555F mutations produced fully functional channels, indicating that aromatic side-chains are required at these positions.

\section{Mutations providing structural information of the channel without having phenotype}

Ryu et al. investigated mutations of other residues (D601-S611, Y627-F640 and D646-E651) that had minimal consequences, leaving CAPS and low $\mathrm{pH}$ responses mostly intact. These included radical perturbations such as the charge mutations N628R and S632D, suggesting that these residues are probably exposed to the aqueous phase. Such an arrangement would be consistent with their positions in a helix, which renders T633 facing away from the aqueous phase, making it accessible to interaction with other residues [192]. The function of the channel appeared quite sensitive to perturbations at the position 538 (V538L, V538A, V538G, V538I, V538T). Even the relatively conservative substitution with Ala abrogated the low $\mathrm{pH}$ currents and also reduced the CAPS activity. Further reduction of the size of the side-chain with a substitution by Gly resulted in non-functional channels. It appeared that the local structure of the channel lacks rigidity to tolerate a smaller side-chain at this position. However, the size of the sidechain was not the only factor determining the function of the residue. Replacement by Ile, which has the same volume as Leu, recovered a small, but significant portion of the low $\mathrm{pH}$ activity. The data appeared to consist of two populations, one similar to the wild type and the other to V538L, as if the local structure of the channel existed in some metastates. Finally, Thr substitution, which preserved the side-chain size, did not confer the wild type responses either. Together, these data indicate that multiple aspects of the side-chain, including both volume and steric hindrance are important for the function of the residue [192].

\section{Deletion mutants}

An N-terminus deletion mutant by Jung et al. [16], $\Delta^{1-109}$, which elicited $I_{\text {cap }}$, retained specific binding for $\left[{ }^{3} \mathrm{H}\right] \mathrm{RTX}$. In contrast, cells expressing $\Delta^{1-114}$, which failed to show $\mathrm{I}_{\text {cap }}$, completely lost their specific binding to $\left[{ }^{3} \mathrm{H}\right] \mathrm{RTX}$. Similarly, deletion mutants at the $C$ terminus, such as $\Delta^{762-838}$ and $\Delta^{763-838}$, which displayed smaller $I_{\text {cap }}$, bound $\left[{ }^{3} \mathrm{H}\right]$ RTX similarly to the wild type. In contrast, $\Delta^{761-838}$, which failed to elicit $\mathrm{I}_{\text {cap }}$, had no ability to specifically bind $\left[{ }^{3} \mathrm{H}\right] \mathrm{RTX}$. Deletion mutants that lacked one of these two regions lost current sensitivity to CAPS and the ability to bind ligands. The two regions in the vicinity of R114 and E761 are critical for ligand binding and that the loss of these regions abrogates vanilloid activation. A deletion as small as a single amino acid affects the ligand binding. $\Delta^{114}$ and $\Delta^{761}$ failed to elicit CAPS-sensitive inward currents. Furthermore, the mutants did not show specific binding to $\left[{ }^{3} \mathrm{H}\right] \mathrm{RTX}$. Both mutants elicited whole-cell currents when activated by heat at $\sim 46^{\circ} \mathrm{C}$, but both mutants failed to respond to acid ( $\mathrm{pH} 5.5)$ [16].

Deletion of a Thr residue in TM4 $\left(\Delta^{\mathrm{T} 550}\right)$ reduced CAPS sensitivity [171] (Figure 1).

To investigate the contribution of the pore turret to the TRPV1 function, Cui et al. [190] generated a series of turret deletion mutations by deleting the first 10 $\left(\Delta^{\mathrm{G} 603-\mathrm{S} 612}\right), 17\left(\Delta^{\mathrm{G} 603-\mathrm{G} 619}\right)$, or all 24 amino acids $\left(\Delta^{\mathrm{G} 603-}{ }^{\mathrm{N} 626}\right)$, and also deleted seven amino acids from the C-terminal end of the turret $\left(\Delta^{\mathrm{S} 620-\mathrm{N} 626}\right)$.

$\Delta^{\text {G603-S612 }}$ mutant channel was found to be functional, and exhibited nearly identical CAPS sensitivity to that of the wild type. As CAPS exhibited very similar potency and efficacy in activating wild type and $\Delta^{\mathrm{G} 603-\mathrm{S} 612}$ 
Table 1 Summary table of the mutants discussed in the article

\begin{tabular}{|c|c|c|c|}
\hline Residue & Mutated to & Role in the channel function / Impact of the mutation on the channel function & Refs \\
\hline $\mathrm{C} 73$ & S & $\begin{array}{l}\text { Its mutation caused gain of function and strong toxicity when expressed in } \\
\text { Saccharomyces cerevisiae. }\end{array}$ & [177] \\
\hline 175 & $\mathrm{~F}$ & $\begin{array}{l}\text { Its mutation caused gain of function mutation and weaker toxicity when expressed in } \\
\text { Saccharomyces cerevisiae. }\end{array}$ & [177] \\
\hline 176 & $\mathrm{~T}$ & $\begin{array}{l}\text { Its mutation caused gain of function mutation and weaker toxicity when expressed in } \\
\text { Saccharomyces cerevisiae. }\end{array}$ & [177] \\
\hline V78 & G & $\begin{array}{l}\text { Its mutation caused gain of function mutation and weaker toxicity when expressed in } \\
\text { Saccharomyces cerevisiae. }\end{array}$ & [177] \\
\hline R114 & $\mathrm{A}, \mathrm{E}, \Delta$ & $\begin{array}{l}\text { Its deletion or mutation abrogated vanilloid and proton activation and RTX binding, } \\
\text { without effecting heat activation. }\end{array}$ & [16] \\
\hline R115 & $\mathrm{D}$ & $\begin{array}{l}\text { Its mutation abrogated vanilloid activation and RTX binding, without effecting heat } \\
\text { activation. }\end{array}$ & [16] \\
\hline S116 & A & $\begin{array}{l}\text { The residue is phosphorylated by PKA and is involved in desensitization. It is also } \\
\text { functional target for PKC } \mu \text {. Its mutation abolished phosphorylation by PKC } \mu \text { and } \\
\text { enhanced the channel response to CAPS by PKC } \mu \text {. }\end{array}$ & {$[85,90,176,210]$} \\
\hline T144 & & Its phosphorylation by PKA causes sensitization of heat-evoked responses. & {$[78,83]$} \\
\hline \multirow[t]{2}{*}{ K155 } & $A, E$ & $\begin{array}{l}\text { Its mutation caused impaired TRPV1-ARD interaction with ATP, and impaired } \\
\text { tachyphylaxis, even in the absence of ATP. The mutant channel did not interact with } \\
\text { CaM, and was slightly more sensitive to CAPS than the wild type. }\end{array}$ & {$[14,177]$} \\
\hline & & $\begin{array}{l}\text { Its mutation resulted in a constitutively active channel, and caused gain of function } \\
\text { mutation and weaker toxicity when expressed in Saccharomyces cerevisiae. }\end{array}$ & \\
\hline C157 & & The residue is covalently modified by allicin causing allicin activation of the channel. & [187] \\
\hline \multirow[t]{2}{*}{ K160 } & $A, E$ & $\begin{array}{l}\text { Its mutation caused impaired TRPV1-ARD interaction with ATP, and impaired } \\
\text { tachyphylaxis, even in the absence of ATP. The mutant channel did not interact with } \\
\text { CaM, and was slightly more sensitive to CAPS than the wild type. }\end{array}$ & {$[14,177]$} \\
\hline & & $\begin{array}{l}\text { Its mutation resulted in a constitutively active channel, caused gain of function } \\
\text { mutation and strong toxicity when expressed in Saccharomyces cerevisiae. }\end{array}$ & \\
\hline H166 & R & $\begin{array}{l}\text { Its mutation caused gain of function mutation and weaker toxicity when expressed in } \\
\text { Saccharomyces cerevisiae. Its mutation resulted in significant response to } \mathrm{pH} 6.4 \\
\text { (threshold concentration for proton-activation). }\end{array}$ & [177] \\
\hline D178 & $\mathrm{N}$ & Its mutation abolished the ATP-mediated upregulation of TRPV1. & [205] \\
\hline \multirow[t]{2}{*}{ Y199 } & $A, F$ & $\begin{array}{l}\text { When both sites were mutated, Y199/Q202 impaired the TRPV1-ARD interaction with } \\
\text { ATP and ATP-mediated tachyphylaxis. The mutated channel was slightly more sensitive } \\
\text { to CAPS than the wild type. Mutant channels formed a weaker complex with CaM than } \\
\text { wild type but it still had a 1:1 stoichiometric ratio. }\end{array}$ & {$[14,211]$} \\
\hline & & $\begin{array}{l}\text { Phosphorylation of hTRPV1 Y200 (Y199 in rTRPV1) by Src kinase increases the surface } \\
\text { expression of TRPV1 and accounts for rapid sensitizing actions of NGF. When mutated, } \\
\text { Src-dependent, NGF-induced Tyr phosphorylation was completely abolished. }\end{array}$ & \\
\hline Q202 & A & $\begin{array}{l}\text { When both sites were mutated, Y199/Q202 impaired the TRPV1-ARD interaction with } \\
\text { ATP and ATP-mediated tachyphylaxis. The mutated channel was slightly more sensitive } \\
\text { to CAPS than the wild type. Mutant channels formed a weaker complex with CaM than } \\
\text { wild type but it still had a 1:1 stoichiometric ratio. }\end{array}$ & [14] \\
\hline N310 & $\mathrm{D}$ & $\begin{array}{l}\text { Its mutation caused gain of function and weaker toxicity when expressed in } \\
\text { Saccharomyces cerevisiae. }\end{array}$ & [177] \\
\hline S343 & $G, R$ & $\begin{array}{l}\text { Its mutation caused gain of function and strong/weak toxicity when expressed in } \\
\text { Saccharomyces cerevisiae. }\end{array}$ & [177] \\
\hline A350 & $\mathrm{T}$ & $\begin{array}{l}\text { Its mutation caused gain of function and strong toxicity when expressed in } \\
\text { Saccharomyces cerevisiae. }\end{array}$ & [177] \\
\hline 1352 & $\mathrm{~N}, \mathrm{~T}$ & $\begin{array}{l}\text { Its mutation caused gain of function mutation and weaker toxicity when expressed in } \\
\text { Saccharomyces cerevisiae. Its mutation also caused significant response to } \mathrm{pH} 6.4\end{array}$ & [177] \\
\hline
\end{tabular}
(threshold concentration for proton-activation). and in the sensitization of heat-evoked TRPV1 responses when phosphorylated by PKA. 
Table 1 Summary table of the mutants discussed in the article (Continued)

\begin{tabular}{|c|c|c|c|}
\hline R491 & $E, G$ & Mutation caused reduction in CAPS sensitivity. & [168] \\
\hline \multirow[t]{4}{*}{ S502 } & A & $\begin{array}{l}\text { Its phosphorylation by PKC potentiates CAPS, proton, and thermal responses, and that } \\
\text { by PKA sensitizes the heat-evoked responses. }\end{array}$ & {$[78,83,85,91,174,209]$} \\
\hline & & It is a CaMKII phosphorylation site. & \\
\hline & & $\begin{array}{l}\text { When associated with T704l, S502A was found to lose the ability to be activated by } \\
\text { CAPS and to lose the ability of vanilloid binding. }\end{array}$ & \\
\hline & & $\begin{array}{l}\text { Its mutation reduced PMA enhancement of CAPS-evoked currents, but had no effect } \\
\text { on direct activation by PMA. }\end{array}$ & \\
\hline Y511 & $A, C, F$, & $\begin{array}{l}\text { Its mutation abolished CAPS responses, and RTX binding yet leave activation by heat } \\
\text { and protons intact. }\end{array}$ & {$[168-171,180]$} \\
\hline S512 & $A, F, T, Y$ & $\begin{array}{l}\text { Its mutation abolished CAPS responses and RTX binding, yet left activation by heat and } \\
\text { protons intact. It is involved in I-RTX binding. }\end{array}$ & {$[168,169,173,193]$} \\
\hline Q519 & $\mathrm{N}$ & Its mutation ablated the vanilloid sensitivity. & [168] \\
\hline F522 & L & Its mutation ablated the vanilloid sensitivity. & [168] \\
\hline M523 & $\mathrm{L}$ & Its mutation ablated the vanilloid sensitivity. & [168] \\
\hline S532 & C & Its mutation ablated the vanilloid sensitivity. & [168] \\
\hline K535 & $\mathrm{E}$ & Its mutation ablated the vanilloid sensitivity, and affected proton responses. & {$[168,192]$} \\
\hline E536 & $L, W$ & Its mutation ablated the vanilloid sensitivity, and affected proton responses. & {$[168,192]$} \\
\hline V538 & $A, G, I, L, T$ & Its mutation ablated proton activation, but not the proton potentiation. & [192] \\
\hline A539 & $\mathrm{P}$ & Its mutation affected proton responses. & [192] \\
\hline M547 & $A, I, L, Q$ & $\begin{array}{l}\text { The residue is involved in RTX binding, CAPS sensitivity, I-RTX sensitivity and proton } \\
\text { sensitivity. }\end{array}$ & {$[168,170,171,173,180]$} \\
\hline W549 & & It is involved in vanilloid binding. & {$[171,182]$} \\
\hline \multirow[t]{2}{*}{ T550 } & $A, C, I, S, Y, \Delta$ & $\begin{array}{l}\text { It is an important molecular determinant in vanilloid sensitivity. Participates in Caps } \\
\text { and RTX binding. }\end{array}$ & {$[168,170,171,180]$} \\
\hline & & Its deletion reduced CAPS sensitivity of the channel. & \\
\hline \multirow[t]{3}{*}{ R557 } & $A, E, K, L$ & $\begin{array}{l}\text { It is involved in CAPS potentiation of heat-induced currents and in the transduction of } \\
\text { the CAPS-binding signal to the opening of the pore. }\end{array}$ & [179] \\
\hline & & $\begin{array}{l}\text { It is also important in deactivation gating process, 2-APB activation and for voltage- } \\
\text { dependent gating. }\end{array}$ & \\
\hline & & $\begin{array}{l}\text { It contributes to the voltage modulation of the CAPS-induced currents and the CAPS } \\
\text { potentiation of the heat-induced currents. }\end{array}$ & \\
\hline \multirow[t]{4}{*}{ Q560 } & $H, R$ & It is involved in the transduction of the CAPS-binding signal to the opening of the pore. & {$[177,179]$} \\
\hline & & It is also important in deactivation gating process and for 2-APB activation. & \\
\hline & & $\begin{array}{l}\text { Its mutation caused significant response to } \mathrm{pH} 6.4 \text { (threshold concentration for proton- } \\
\text { activation). }\end{array}$ & \\
\hline & & $\begin{array}{l}\text { Its mutation caused gain of function of the channel and weaker toxicity when } \\
\text { expressed in Saccharomyces cerevisiae. }\end{array}$ & \\
\hline Q561 & $H, R$ & $\begin{array}{l}\text { Its mutation caused gain of function of the channel and strong toxicity when } \\
\text { expressed in Saccharomyces cerevisiae. }\end{array}$ & [177] \\
\hline M562 & $\mathrm{D}$ & $\begin{array}{l}\text { Its mutation caused significant response to } \mathrm{pH} 6.4 \text { (threshold concentration for proton- } \\
\text { activation). }\end{array}$ & [177] \\
\hline G563 & S & The residue is involved in the voltage gating of the channel. & [179] \\
\hline \multirow[t]{3}{*}{ E570 } & $A, L, Q, R$ & $\begin{array}{l}\text { The residue contributes to the voltage modulation of the CAPS-induced currents and } \\
\text { the CAPS potentiation of the heat-induced currents. }\end{array}$ & [179] \\
\hline & & $\begin{array}{l}\text { It is involved in the transduction of the CAPS-binding signal to the opening of the } \\
\text { pore and in the 2-APB activation of the channel. }\end{array}$ & \\
\hline & & It is also a relevant heat-sensing factor. & \\
\hline \multirow[t]{2}{*}{ K571 } & $\mathrm{E}$ & The residue is a specific binding site for 2-APB. & {$[172,179,191,196]$} \\
\hline & & It is involved in voltage sensing and in TRPV1-lipid interactions. & \\
\hline R575 & A & The residue is involved in voltage sensing and in TRPV1-lipid interactions. & {$[172,191,196]$} \\
\hline
\end{tabular}


Table 1 Summary table of the mutants discussed in the article (Continued)

\begin{tabular}{|c|c|c|c|}
\hline \multirow[t]{2}{*}{ D576 } & $N, R$ & $\begin{array}{l}\text { The residue is involved in the voltage-dependent gating of TRPV1, and contributes to } \\
\text { the voltage modulation of the CAPS-induced currents and the CAPS potentiation of } \\
\text { the heat-induced currents. }\end{array}$ & [179] \\
\hline & & It contributes to the transduction of the CAPS-binding signal to the opening of the pore. & \\
\hline R579 & $A, D, E$ & $\begin{array}{l}\text { The residue contributes to the voltage modulation of the CAPS-induced currents and to the } \\
\text { CAPS potentiation of heat-induced currents. It is involved in the voltage sensing and in } \\
\text { TRPV1-lipid interactions. Its mutation decreased the cholesterol response of the channel. }\end{array}$ & {$[172,179,191,196,208]$} \\
\hline \multirow[t]{2}{*}{ M581 } & $\mathrm{T}$ & $\begin{array}{l}\text { The residue contributes to the transduction of the CAPS-binding signal to the opening } \\
\text { of the pore, and to the deactivation gating process. It is involved in voltage gating. }\end{array}$ & {$[177,179]$} \\
\hline & & $\begin{array}{l}\text { Its mutation caused gain of function of the channel and strong toxicity when } \\
\text { expressed in Saccharomyces cerevisiae. }\end{array}$ & \\
\hline F582 & Q & Its mutation decreased the cholesterol response of the channel. & [208] \\
\hline L585 & I & Its mutation abolished the cholesterol response of the channel. & [208] \\
\hline 1599 & A & Its mutation caused reduced DkTx responses. & [207] \\
\hline E600 & $A, D, H, K, Q, S, V$ & $\begin{array}{l}\text { The residue is involved in the proton potentiation, but not in proton activation. } \\
\text { Its mutation to neutral or positive residues potentiates responses to CAPS or heat, and } \\
\text { introduction of a residue with lower pKa decreased the channel sensitivity to CAPS or heat. }\end{array}$ & {$[43,167]$} \\
\hline D601 & N & $\begin{array}{l}\text { Its mutation reduced the proton-activated currents significantly, without altering the } \\
\text { heat- or CAPS-evoked responses, and without eliminating the ability of protons to } \\
\text { potentiate the responses to these stimuli. }\end{array}$ & [43] \\
\hline M609 & $\mathrm{T}, \mathrm{V}$ & $\begin{array}{l}\text { Its mutation caused gain of function of the channel and strong/weak toxicity when } \\
\text { expressed in Saccharomyces cerevisiae. }\end{array}$ & [177] \\
\hline C616 & G & The residue is involved in DTT interaction. & {$[78,112,207]$} \\
\hline C621 & G & $\begin{array}{l}\text { The residue is responsible for the extracellular modulation of TRPV1 by reducing } \\
\text { agents. It is involved in DTT interaction. Its mutation and when associated with C616G } \\
\text { and C634G significantly reduced DDT potentiation without having any effect on the } \\
\text { CAPS, heat or voltage gating of the channel. }\end{array}$ & {$[78,112,207]$} \\
\hline N625 & $\mathrm{D}$ & Its mutation caused toxicity when expressed in Saccharomyces cerevisiae. & [177] \\
\hline Y627 & A, W & $\begin{array}{l}\text { The residue contributes to, but do not play a pivotal role in the proton activation. Its } \\
\text { mutation enhanced the sensitivity to the acylpolyamine toxins AG489 and AG505. }\end{array}$ & {$[192,200]$} \\
\hline N628 & $D, K, R, W$ & $\begin{array}{l}\text { The residue plays essential roles in the heat response without affecting the CAPS } \\
\text { responses or the desensitization of the channel. It is involved in proton-induced } \\
\text { potentiation. Its mutation reduced the heat responses in amplitude and shifted them to } \\
\text { higher temperatures, dramatically decreased the sensitivity to the acylpolyamine toxins } \\
\text { AG489 and AG505 and caused toxicity when expressed in Saccharomyces cerevisiae. }\end{array}$ & {$[167,177,192,200,213]$} \\
\hline S629 & A & The residue contributes to, but do not play a pivotal role in the proton activation. & [192] \\
\hline T633 & $A, S, V$ & $\begin{array}{l}\text { Its mutation eliminated the proton-activated currents while leaving normal responses } \\
\text { to CAPS and low pH potentiation. Its mutation exhibited a weaker response to heat in } \\
\text { amplitude, however, the thermal activation threshold was unchanged. }\end{array}$ & [192] \\
\hline C634 & $G, S, W$ & $\begin{array}{l}\text { It is involved in DTT interaction, its mutation and when associated with C616G and } \\
\text { C621G significantly reduced DDT potentiation without having any effect on the CAPS, } \\
\text { heat or voltage gating of the channel. Its mutation also enhanced the sensitivity to the } \\
\text { acylpolyamine toxins AG489 and AG505, and caused toxicity when expressed in } \\
\text { Saccharomyces cerevisiae. }\end{array}$ & {$[78,112,177,200,207]$} \\
\hline E636 & $\mathrm{Q}, \mathrm{W}$ & $\begin{array}{l}\text { The residue is a specific contributor to the CAPS response without affecting the proton } \\
\text { or thermal sensitivity. Its mutation dramatically decreased the sensitivity to the } \\
\text { acylpolyamine toxins AG489 and AG505. }\end{array}$ & {$[43,165,200]$} \\
\hline F638 & W & Its mutation enhanced the sensitivity to the acylpolyamine toxins AG489 and AG505. & [200] \\
\hline F640 & $\begin{array}{l}A, C, D, E, G, H, I, K, L, M, N, \\
\quad P, Q, R, S, T, V, W, Y,\end{array}$ & $\begin{array}{l}\text { The residue is critical for heat activation. Its mutation was constitutively active, and } \\
\text { caused strong toxicity when expressed in Saccharomyces cerevisiae. Its mutation also } \\
\text { enhanced the sensitivity to heat and CAPS, and abolished the proton potentiation of } \\
\text { the channel. This mutation affected gating rather than permeation properties of the } \\
\text { channel. }\end{array}$ & [177] \\
\hline T641 & S & The residue is involved in acid activation and potentiation. Its mutant displayed large & [177] \\
\hline
\end{tabular}




\section{Table 1 Summary table of the mutants discussed in the article (Continued)}

\begin{tabular}{cc}
\hline D646 & N, W \\
L647 & W \\
E648 & A, Q \\
F649 & A, W \\
T650 & S \\
E651 & \\
N652 & Q, W \\
& D, T \\
Y653 & \\
V658 & A \\
K656 & T \\
\hline
\end{tabular}

The residue is a specific contributor to the CAPS response without affecting the proton
or thermal sensitivity, and it is engaged in inhibition by RuRed. Its mutation reduced
the permeability of divalent cations and dramatically decreased the sensitivity to the acylpolyamine toxins AG489 and AG505.

Its mutation enhanced the sensitivity to the acylpolyamine toxins AG489 and AG505.

The residue is a specific contributor to the CAPS response without affecting the proton or thermal sensitivity. Its mutation reduced the proton-activated currents significantly, without altering the heat- or CAPS-evoked responses, and without eliminating the ability of protons to potentiate the responses to these stimuli.

Its mutation caused reduced DkTx responses, and enhanced the sensitivity to the acylpolyamine toxins AG489 and AG505.

The residue is involved in proton-induced potentiation. Its mutation caused large constitutive channel activation with abolished pH sensitivity. Its mutation caused toxicity when expressed in Saccharomyces cerevisiae.

The residue is important in $\mathrm{pH}$ activation. Its mutation dramatically decreased the sensitivity to the acylpolyamine toxins AG489 and AG505.

The residue plays essential roles in the heat response without affecting the CAPS responses or the desensitization of the channel. Its mutation reduced the heat responses in amplitude and shifted them to higher temperatures. Its mutation also caused gain of function and strong toxicity when expressed in Saccharomyces cerevisiae.

The residue plays essential roles in the heat response without affecting the CAPS responses or the desensitization of the channel. Its mutation reduced the heat responses in amplitude and shifted them to higher temperatures.

Its mutation caused toxicity when expressed in Saccharomyces cerevisiae.

The residue is critical for DkTx binding, its mutation showed loss of DkTx sensitivity.

The residue is involved in acid potentiation. Its mutation showed a potentiation effect under moderately acidic conditions. Its mutation also caused toxicity when expressed in Saccharomyces cerevisiae.

The residue is involved in proton activation, and is a key integrator of voltage sensing, proton activation and potentiation. Its mutation caused lack of both voltagedependent proton activation and potentiation, whereas activation by heat or CAPS was preserved. Its mutation caused reduced DkTx responses and caused toxicity when expressed in Saccharomyces cerevisiae.

Its mutation resulted in non-functional channel.

Its mutation reduced CAPS sensitivity, heat-induced current responses and heatpotentiated CAPS currents.

The residue is involved in heat activation but not in CAPS activation, nor in the heat potentiation of the CAPS currents.

The residue might contribute to allosteric coupling between temperature- and CAPSdependent activation mechanisms. Its mutation affected the heat-induced current responses, lowered the CAPS EC 50 value of the channel. Responses to CAPS were not potentiated by heat in the mutant containing channel, in fact CAPS-evoked responses were inhibited by heat. The residue is involved in the regulation of permeability of divalent cations, it gates the access of smaller cations.

Its mutation reduced CAPS sensitivity, heat-induced current responses and heatpotentiated CAPS currents.

Its mutation caused gain of function and strong toxicity when expressed in Saccharomyces cerevisiae. Its mutation also reduced CAPS sensitivity, heat-induced current responses and heat-potentiated CAPS currents.

Its mutation reduced CAPS sensitivity, heat-induced current responses and heatpotentiated CAPS currents.

Its mutation reduced CAPS sensitivity and heat-potentiated CAPS currents.

Its mutation influenced the ability of CAPS and RTX to activate TRPV1 without changing the response of the channel to protons. Its mutation to Ala resulted in nonfunctional channel.

Its mutation in a triple mutant (N676F/M677A/L678P) influenced the ability of CAPS and RTX to activate TRPV1 without changing the response of the channel to protons. Its mutation alone blunted heat-induced current responses without a significant change of CAPS- or heat-potentiated CAPS currents. 


\section{Table 1 Summary table of the mutants discussed in the article (Continued)}

\begin{tabular}{|c|c|c|c|}
\hline L678 & $A, P$ & $\begin{array}{l}\text { Its mutation influenced the ability of CAPS and RTX to activate TRPV1 without } \\
\text { changing the response of the channel to protons. Its mutation also blunted heat- } \\
\text { induced current responses, with a leftward shift in the temperature threshold. }\end{array}$ & {$[166,175]$} \\
\hline 1679 & A & $\begin{array}{l}\text { Its mutation retained normal sensitivities to CAPS and heat, although it completely } \\
\text { removed their mutual potentiation. }\end{array}$ & {$[175]$} \\
\hline L681 & A & $\begin{array}{l}\text { The residue is involved in the regulation of permeability of divalent cations, it regulates } \\
\text { the permeability of large cations. }\end{array}$ & {$[169,175,178]$} \\
\hline M682 & A & $\begin{array}{l}\text { Its mutation caused impaired CAPS- and heat- activation, and significantly reduced } \\
\text { their mutual potentiation. }\end{array}$ & {$[175]$} \\
\hline E684 & $G, V$ & $\begin{array}{l}\text { Its mutation caused gain of function and strong toxicity when expressed in } \\
\text { Saccharomyces cerevisiae. Its mutation caused significant response to pH } 6.4 \text { (threshold } \\
\text { concentration for proton-activation). }\end{array}$ & {$[177]$} \\
\hline 1689 & V & $\begin{array}{l}\text { Its mutation caused gain of function mutation and weaker toxicity when expressed in } \\
\text { Saccharomyces cerevisiae. }\end{array}$ & {$[177]$} \\
\hline K694 & A & The residue participates in PIP2 binding. & {$[206]$} \\
\hline K698 & A & The residue participates in PIP2 binding. & [206] \\
\hline Q700 & A & The residue participates in PIP2 binding. & [206] \\
\hline R701 & A & The residue participates in PIP2 binding. & {$[191,206]$} \\
\hline T704 & 1 & $\begin{array}{l}\left.\text { The residue is a CaMKII phosphorylation site. PMA decreases the binding of }{ }^{3} \mathrm{H}\right] \mathrm{RTX} \text { to } \\
\text { TRPV } 1 \text { through interaction with this residue. When associated with } 5502 \mathrm{~A} \text {, its mutation } \\
\text { lost the ability to be activated by CAPS and lost the ability of vanilloid binding. }\end{array}$ & {$[46,85,91,115,174]$} \\
\hline K710 & $A, R$ & $\begin{array}{l}\text { The residue participates in PIP2 binding. Its mutation caused gain of function and } \\
\text { strong toxicity when expressed in Saccharomyces cerevisiae. }\end{array}$ & {$[177,191,206]$} \\
\hline Q727 & & The residue has key roles in heat activation. & [191] \\
\hline F742 & $\mathrm{S}$ & $\begin{array}{l}\text { Its mutation caused gain of function and strong toxicity when expressed in } \\
\text { Saccharomyces cerevisiae. }\end{array}$ & [177] \\
\hline W752 & & The residue has key roles in heat activation. & [191] \\
\hline E761 & $\mathrm{K}, \mathrm{Q}, \Delta$ & $\begin{array}{l}\text { Its deletion or mutation blocks RTX binding and proton- and CAPS-induced currents } \\
\text { without affecting TRPV1 activation by heat. }\end{array}$ & {$[16,175,176]$} \\
\hline K770 & A & The residue participates in PIP2 binding. & {$[206]$} \\
\hline R771 & A & The residue participates in PIP2 binding. & {$[206]$} \\
\hline R778 & A & The residue has key roles in PIP2 binding. & {$[201,206]$} \\
\hline R781 & A & The residue has key roles in PIP2 binding. & {$[201,206]$} \\
\hline R785 & A & The residue participates in PIP2 binding. & {$[201,206]$} \\
\hline W787 & $\mathrm{R}$ & $\begin{array}{l}\text { Its mutation caused gain of function and strong toxicity when expressed in } \\
\text { Saccharomyces cerevisiae. }\end{array}$ & {$[177]$} \\
\hline L792 & $P$ & $\begin{array}{l}\text { Its mutation caused gain of function mutation and weaker toxicity when expressed in } \\
\text { Saccharomyces cerevisiae. Its mutation caused significant response to } \mathrm{pH} 6.4 \text { (threshold } \\
\text { concentration for proton-activation). }\end{array}$ & {$[177]$} \\
\hline L796 & $P, V$ & $\begin{array}{l}\text { Its mutation caused gain of function and strong/weaker toxicity when expressed in } \\
\text { Saccharomyces cerevisiae. }\end{array}$ & [177] \\
\hline 5800 & A & Its phosphorylation by PKC potentiates CAPS, acid, and thermal responses. & {$[78,85,209]$} \\
\hline
\end{tabular}

channels, this partial turret deletion does not seem to directly affect CAPS activation.

$\Delta^{\text {G603-S612 }}$ reduced the heat response of the channel, which was not a result of slow gating kinetics, as lengthening the heat pulse did not yield any increase in the current amplitude, heat becomes a less effective activator for the $\Delta^{\text {G603-S612 }}$ mutant channel.

Cui et al. found that, the turret deletion mutations $\Delta^{\text {G603-G619 }}$ and $\Delta^{\text {G603-N626 }}$ completely disrupted channel function; no current could be detected from channelexpressing cells challenged with either $10 \mu \mathrm{M}$ CAPS or high temperatures up to $50^{\circ} \mathrm{C}$ despite the normal cellular distribution of the mutant channels similar to that of the wild type TRPV1 [190].

\section{Additional file}

Additional file 1: Summary of the mutated sites of rTRPV1. 


\section{Competing interests}

The authors declare that they have no competing interests.

\section{Authors' contributions}

ZW designed the study prepared the manuscript the figure and the table. $A B, F O ̈, K J$ and $C V$ have been involved in drafting and revising the manuscript. GD, GS and ZO have been involved in revising the manuscript and in the interpretation of data. All authors read and approved the final manuscript.

\section{Acknowledgments}

This work was supported by grants from the National Office for Research and Technology (OMFB-01630; OMFB-01703, OMFB-01576/2006 and BAROSS_DA07-DA_TECH_07-2008-0043). ZO was supported by Marie Curie European Re-integration Grant MCIRG030854-PAINKILLER; Ányos Jedlik Program NKFP-1-00019/2005; GVOP-3.3.1-05/1.-2005-05-0057/3.0, and BAROSS_DA07-DA_TECH_07-2008-0028. CV was supported by grants from the National Office for Research and Technology (OM-00051/2005, OMFB01575/2006, ERC_HU_09 3D_TRPV1 OMFB-01813/2009 and TÁMOP-4.2.1.B09/1/KONV) and the Hungarian Ministry of Health (552/2006). GS and CV are grateful for the award of Bolyai Fellowships of the Hungarian Academy of Sciences. The authors would like to express their appreciation to our native speaker lector for proofreading the manuscript.

\section{Author details}

${ }^{1}$ Institute of Pharmaceutical Analysis, Faculty of Pharmacy, University of Szeged, Szeged, Hungary. ${ }^{2}$ Institute of Biochemistry, Biological Research Centre of the Hungarian Academy of Sciences, Szeged, Hungary. ${ }^{3}$ Acheuron Hungary Ltd, Szeged, Hungary.

\section{Received: 18 March 2013 Accepted: 17 June 2013}

Published: 22 June 2013

\section{References}

1. Carlson AE, Westenbroek RE, Quill T, Ren D, Clapham DE, Hille B, Garbers DL, Babcock DF: CatSper1 required for evoked $\mathrm{Ca} 2+$ entry and control of flagellar function in sperm. Proc Natl Acad Sci U S A 2003, 100:1486414868.

2. Cosens DJ, Manning A: Abnormal electroretinogram from a Drosophila mutant. Nature 1969, 224:285-287.

3. O'Neill J, Brock C, Olesen AE, Andresen T, Nilsson M, Dickenson AH: Unravelling the mystery of capsaicin: a tool to understand and treat pain. Pharmacol Rev 2012, 64:939-971.

4. Venkatachalam K, Montell C: TRP channels. Annu Rev Biochem 2007, 76:387-417.

5. Owsianik G, Talavera K, Voets T, Nilius B: Permeation and selectivity of TRP channels. Annu Rev Physiol 2006, 68:685-717.

6. Li M, Yu Y, Yang J: Structural biology of TRP channels. Adv Exp Med Biol 2011, 704:1-23.

7. Landry Y, Gies JP: Drugs and their molecular targets: an updated overview. Fundam Clin Pharmacol 2008, 22:1-18.

8. Okuhara DY, Hsia AY, Xie M: Transient receptor potential channels as drug targets. Expert Opin Ther Targets 2007, 11:391-401.

9. Szallasi A, Cortright DN, Blum CA, Eid SR: The vanilloid receptor TRPV1: 10 years from channel cloning to antagonist proof-of-concept. Nat Rev Drug Discov 2007, 6:357-372.

10. Nilius B, Vennekens R: Gomtsyan A, Faltynek CR. In Vanilloid Receptor TRPV1 in Drug Discovery: Targeting Pain and Other Pathological Disorders. Hoboken, NJ, USA: John Wiley \& Sons, Inc; 2010.

11. Xu SZ, Zeng F, Boulay G, Grimm C, Harteneck C, Beech DJ: Block of TRPC5 channels by 2-aminoethoxydiphenyl borate: a differential, extracellular and voltage-dependent effect. Br J Pharmacol 2005, 145:405-414.

12. Jin X, Touhey J, Gaudet R: Structure of the N-terminal ankyrin repeat domain of the TRPV2 ion channel. J Biol Chem 2006, 281:25006-25010.

13. McCleverty CJ, Koesema E, Patapoutian A, Lesley SA, Kreusch A: Crystal structure of the human TRPV2 channel ankyrin repeat domain. Protein Sci 2006, 15:2201-2206.

14. Lishko PV, Procko E, Jin X, Phelps CB, Gaudet R: The ankyrin repeats of TRPV1 bind multiple ligands and modulate channel sensitivity. Neuron 2007, 54:905-918.
15. Hellwig N, Albrecht N, Harteneck C, Schultz G, Schaefer M: Homo- and heteromeric assembly of TRPV channel subunits. J Cell Sci 2005, 118:917928.

16. Jung J, Lee SY, Hwang SW, Cho H, Shin J, Kang YS, Kim S, Oh U: Agonist recognition sites in the cytosolic tails of vanilloid receptor 1. J Biol Chem 2002, 277:44448-44454.

17. Mosavi LK, Cammett TJ, Desrosiers DC, Peng ZY: The ankyrin repeat as molecular architecture for protein recognition. Protein Sci 2004, 13:14351448.

18. Sedgwick SG, Smerdon SJ: The ankyrin repeat: a diversity of interactions on a common structural framework. Trends Biochem Sci 1999, 24:311-316.

19. Vennekens R, Hoenderop JG, Prenen J, Stuiver M, Willems PH, Droogmans $G$, Nilius B, Bindels RJ: Permeation and gating properties of the novel epithelial $\mathrm{Ca}(2+)$ channel. J Biol Chem 2000, 275:3963-3969.

20. Yue L, Peng JB, Hediger MA, Clapham DE: CaT1 manifests the pore properties of the calcium-release-activated calcium channel. Nature 2001, 410:705-709.

21. Dhaka A, Viswanath $V$, Patapoutian A: Trp ion channels and temperature sensation. Annu Rev Neurosci 2006, 29:135-161.

22. Lawson JJ, Mcllwrath SL, Woodbury CJ, Davis BM, Koerber HR: TRPV1 unlike TRPV2 is restricted to a subset of mechanically insensitive cutaneous nociceptors responding to heat. J Pain 2008, 9:298-308.

23. Xu H, Delling M, Jun JC, Clapham DE: Oregano, thyme and clove-derived flavors and skin sensitizers activate specific TRP channels. Nat Neurosci 2006, 9:628-635.

24. Moqrich A, Hwang SW, Earley TJ, Petrus MJ, Murray AN, Spencer KS, Andahazy M, Story GM, Patapoutian A: Impaired thermosensation in mice lacking TRPV3, a heat and camphor sensor in the skin. Science 2005, 307:1468-1472.

25. Nilius B, Owsianik G, Voets T, Peters JA: Transient receptor potential cation channels in disease. Physiol Rev 2007, 87:165-217.

26. Hoenderop JG, van der Kemp AW, Hartog A, van de Graaf SF, van Os CH, Willems PH, Bindels RJ: Molecular identification of the apical Ca2+ channel in 1, 25-dihydroxyvitamin D3-responsive epithelia. J Biol Chem 1999, 274:8375-8378.

27. Peng JB, Chen XZ, Berger UV, Vassilev PM, Tsukaguchi H, Brown EM, Hediger MA: Molecular cloning and characterization of a channel-like transporter mediating intestinal calcium absorption. J Biol Chem 1999, 274:2273922746.

28. Caterina MJ, Schumacher MA, Tominaga M, Rosen TA, Levine JD, Julius D: The capsaicin receptor: a heat-activated ion channel in the pain pathway. Nature 1997, 389:816-824.

29. Kedei N, Szabo T, Lile JD, Treanor JJ, Olah Z, ladarola MJ, Blumberg PM: Analysis of the native quaternary structure of vanilloid receptor 1. J Biol Chem 2001, 276:28613-28619.

30. Moiseenkova-Bell VY, Stanciu LA: Serysheva, II, Tobe BJ, Wensel TG: Structure of TRPV1 channel revealed by electron cryomicroscopy. Proc Natl Acad Sci U S A 2008, 105:7451-7455.

31. Vriens J, Appendino G, Nilius B: Pharmacology of vanilloid transient receptor potential cation channels. Mol Pharmacol 2009, 75:1262-1279.

32. Szallasi A, Blumberg PM: Resiniferatoxin, a phorbol-related diterpene, acts as an ultrapotent analog of capsaicin, the irritant constituent in red pepper. Neuroscience 1989, 30:515-520.

33. Latorre R, Brauchi S, Orta G, Zaelzer C, Vargas G: ThermotRP channels as modular proteins with allosteric gating. Cell Calcium 2007, 42:427-438.

34. Szallasi A: The vanilloid (capsaicin) receptor: receptor types and species differences. Gen Pharmacol 1994, 25:223-243.

35. Witte DG, Cassar SC, Masters JN, Esbenshade T, Hancock AA: Use of a fluorescent imaging plate reader-based calcium assay to assess pharmacological differences between the human and rat vanilloid receptor. J Biomol Screen 2002, 7:466-475.

36. Culshaw AJ, Bevan S, Christiansen M, Copp P, Davis A, Davis C, Dyson A, Dziadulewicz EK, Edwards L, Eggelte $H$, et al: Identification and biological characterization of 6-aryl-7-isopropylquinazolinones as novel TRPV1 antagonists that are effective in models of chronic pain. J Med Chem 2006, 49:471-474.

37. Pearce LV, Petukhov PA, Szabo T, Kedei N, Bizik F, Kozikowski AP, Blumberg PM: Evodiamine functions as an agonist for the vanilloid receptor TRPV1. Org Biomol Chem 2004, 2:2281-2286.

38. Xu S, Cheng Y, Keast JR, Osborne PB: 17beta-estradiol activates estrogen receptor beta-signalling and inhibits transient receptor potential 
vanilloid receptor 1 activation by capsaicin in adult rat nociceptor neurons. Endocrinology 2008, 149:5540-5548.

39. De Petrocellis L, Bisogno T, Davis JB, Pertwee RG, Di Marzo V: Overlap between the ligand recognition properties of the anandamide transporter and the VR1 vanilloid receptor: inhibitors of anandamide uptake with negligible capsaicin-like activity. FEBS Lett 2000, 483:52-56.

40. Ross RA: Anandamide and vanilloid TRPV1 receptors. Br J Pharmacol 2003, 140:790-801.

41. Ahern GP: Activation of TRPV1 by the satiety factor oleoylethanolamide. J Biol Chem 2003, 278:30429-30434.

42. Hwang SW, Cho H, Kwak J, Lee SY, Kang CJ, Jung J, Cho S, Min KH, Suh YG, Kim D, Oh U: Direct activation of capsaicin receptors by products of lipoxygenases: endogenous capsaicin-like substances. Proc Natl Acad Sci US A 2000, 97:6155-6160.

43. Jordt SE, Tominaga M, Julius D: Acid potentiation of the capsaicin receptor determined by a key extracellular site. Proc Natl Acad Sci U S A 2000, 97:8134-8139.

44. Szallasi A, Blumberg PM: Vanilloid (Capsaicin) receptors and mechanisms. Pharmacol Rev 1999, 51:159-212.

45. Yang BH, Piao ZG, Kim YB, Lee CH, Lee JK, Park K, Kim JS, Oh SB: Activation of vanilloid receptor 1 (VR1) by eugenol. J Dent Res 2003, 82:781-785.

46. Jara-Oseguera A, Simon SA, Rosenbaum T: TRPV1: on the road to pain relief. Curr Mol Pharmacol 2008, 1:255-269.

47. Premkumar LS, Qi ZH, Van Buren J, Raisinghani M: Enhancement of potency and efficacy of NADA by PKC-mediated phosphorylation of vanilloid receptor. J Neurophysiol 2004, 91:1442-1449.

48. Price TJ, Patwardhan A, Akopian AN, Hargreaves KM, Flores CM: Modulation of trigeminal sensory neuron activity by the dual cannabinoid-vanilloid agonists anandamide, $\mathrm{N}$-arachidonoyl-dopamine and arachidonyl-2chloroethylamide. Br J Pharmacol 2004, 141:1118-1130.

49. Suh YG, Oh U: Activation and activators of TRPV1 and their pharmaceutical implication. Curr Pharm Des 2005, 11:2687-2698.

50. Liu L, Simon SA: Similarities and differences in the currents activated by capsaicin, piperine, and zingerone in rat trigeminal ganglion cells. Neurophysiol 1996, 76:1858-1869.

51. McNamara FN, Randall A, Gunthorpe MJ: Effects of piperine, the pungent component of black pepper, at the human vanilloid receptor (TRPV1). $\mathrm{Br}$ J Pharmacol 2005, 144:781-790.

52. Dedov VN, Tran VH, Duke CC, Connor M, Christie MJ, Mandadi S, Roufogalis BD: Gingerols: a novel class of vanilloid receptor (VR1) agonists. Br J Pharmacol 2002, 137:793-798.

53. Iwasaki Y, Morita A, Iwasawa T, Kobata K, Sekiwa Y, Morimitsu Y, Kubota K, Watanabe T: A nonpungent component of steamed ginger-[10]shogaol-increases adrenaline secretion via the activation of TRPV1. Nutr Neurosci 2006, 9:169-178

54. Jung J, Hwang SW, Kwak J, Lee SY, Kang CJ, Kim WB, Kim D, Oh U: Capsaicin binds to the intracellular domain of the capsaicin-activated ion channel. J Neurosci 1999, 19:529-538.

55. Bootman MD, Collins TJ, Mackenzie L, Roderick HL, Berridge MJ, Peppiatt CM: 2-aminoethoxydiphenyl borate (2-APB) is a reliable blocker of storeoperated Ca2+ entry but an inconsistent inhibitor of InsP3-induced Ca2+ release. FASEB J 2002, 16:1145-1150.

56. Bautista DM, Jordt SE, Nikai T, Tsuruda PR, Read AJ, Poblete J, Yamoah EN, Basbaum Al, Julius D: TRPA1 mediates the inflammatory actions of environmental irritants and proalgesic agents. Cell 2006, 124:1269-1282.

57. Macpherson $\sqcup$, Geierstanger BH, Viswanath V, Bandell M, Eid SR, Hwang S, Patapoutian A: The pungency of garlic: activation of TRPA1 and TRPV1 in response to allicin. Curr Biol 2005, 15:929-934.

58. Everaerts W, Gees M, Alpizar YA, Farre R, Leten C, Apetrei A, Dewachter I, van Leuven F, Vennekens $R$, De Ridder D, et al: The capsaicin receptor TRPV1 is a crucial mediator of the noxious effects of mustard oil. Curr Biol 2011, 21:316-321.

59. Mori N, Kawabata F, Matsumura S, Hosokawa H, Kobayashi S, Inoue K, Fushiki T: Intragastric administration of allyl isothiocyanate increases carbohydrate oxidation via TRPV1 but not TRPA1 in mice. Am J Physiol Regul Integr Comp Physiol 2011, 300:R1494-1505.

60. Bandell M, Story GM, Hwang SW, Viswanath V, Eid SR, Petrus MJ, Earley TJ, Patapoutian A: Noxious cold ion channel TRPA1 is activated by pungent compounds and bradykinin. Neuron 2004, 41:849-857.

61. Story GM, Peier AM, Reeve AJ, Eid SR, Mosbacher J, Hricik TR, Earley TJ, Hergarden AC, Andersson DA, Hwang SW, et al: ANKTM1, a TRP-like channel expressed in nociceptive neurons, is activated by cold temperatures. Cell 2003, 112:819-829.

62. Bautista DM, Movahed P, Hinman A, Axelsson HE, Sterner O, Hogestatt ED, Julius $D$, Jordt SE, Zygmunt PM: Pungent products from garlic activate the sensory ion channel TRPA1. Proc Natl Acad Sci U S A 2005, 102:1224812252.

63. Pecze L, Pelsoczi P, Kecskes M, Winter Z, Papp A, Kaszas K, Letoha T, Vizler C, Olah Z: Resiniferatoxin mediated ablation of TRPV1+ neurons removes TRPA1 as well. Can I Neurol Sci 2009, 36:234-241.

64. Szolcsanyi J, Sandor Z: Multisteric TRPV1 nocisensor: a target for analgesics. Trends Pharmacol Sci 2012, 33:646-655.

65. Dray A, Bettaney J, Forster P: Resiniferatoxin, a potent capsaicin-like stimulator of peripheral nociceptors in the neonatal rat tail in vitro. $\mathrm{Br} J$ Pharmacol 1990, 99:323-326.

66. Docherty RJ, Yeats JC, Piper AS: Capsazepine block of voltage-activated calcium channels in adult rat dorsal root ganglion neurones in culture. BrJ Pharmacol 1997, 121:1461-1467.

67. Liu L, Simon SA: Capsazepine, a vanilloid receptor antagonist, inhibits nicotinic acetylcholine receptors in rat trigeminal ganglia. Neurosci Lett 1997, 228:29-32

68. Xia R, Dekermendjian K, Lullau E, Dekker N: TRPV1: a therapy target that attracts the pharmaceutical interests. Adv Exp Med Biol 2011, 704:637-665.

69. Seabrook GR, Sutton KG, Jarolimek W, Hollingworth GJ, Teaque S, Webb J, Clark N, Boyce S, Kerby J, Ali Z, et al: Functional properties of the highaffinity TRPV1 (VR1) vanilloid receptor antagonist (4-hydroxy-5-iodo-3methoxyphenylacetate ester) iodo-resiniferatoxin. J Pharmacol Exp Ther 2002, 303:1052-1060.

70. Planells-Cases R, Aracil A, Merino JM, Gallar J, Perez-Paya E, Belmonte C, Gonzalez-Ros JM, Ferrer-Montiel AV: Arginine-rich peptides are blockers of VR-1 channels with analgesic activity. FEBS Lett 2000, 481:131-136.

71. Himmel HM, Kiss T, Borvendeg SJ, Gillen C, lles P: The arginine-rich hexapeptide R4W2 is a stereoselective antagonist at the vanilloid receptor 1: a Ca2+ imaging study in adult rat dorsal root ganglion neurons. J Pharmacol Exp Ther 2002, 301:981-986.

72. Gavva NR: Body-temperature maintenance as the predominant function of the vanilloid receptor TRPV1. Trends Pharmacol Sci 2008, 29:550-557.

73. Gavva NR, Bannon AW, Surapaneni S, Hovland DN Jr, Lehto SG, Gore A, Juan T, Deng H, Han B, Klionsky L, et al: The vanilloid receptor TRPV1 is tonically activated in vivo and involved in body temperature regulation. J Neurosci 2007, 27:3366-3374.

74. Gavva NR, Treanor JJ, Garami A, Fang L, Surapaneni S, Akrami A, Alvarez F, Bak A, Darling M, Gore A, et al: Pharmacological blockade of the vanilloid receptor TRPV1 elicits marked hyperthermia in humans. Pain 2008, 136:202-210.

75. Wang S, Poon K, Oswald RE, Chuang HH: Distinct modulations of human capsaicin receptor by protons and magnesium through different domains. J Biol Chem 2010, 285:11547-11556.

76. Voets T, Droogmans G, Wissenbach U, Janssens A, Flockerzi V, Nilius B: The principle of temperature-dependent gating in cold- and heat-sensitive TRP channels. Nature 2004, 430:748-754.

77. Ma W, Quirion R: Inflammatory mediators modulating the transient receptor potential vanilloid 1 receptor: therapeutic targets to treat inflammatory and neuropathic pain. Expert Opin Ther Targets 2007, 11:307320.

78. Rosenbaum T, Simon SA: TRPV1 Receptors and Signal Transduction. In TRP Ion Channel Function in Sensory Transduction and Cellular Signaling Cascades. Edited by Liedtke WB, Heller S. Boca Raton (FL): CRC Press; 2007. Chapter 5. Available from: http://www.ncbi.nlm.nih.gov/books/NBK5260/.

79. Tominaga M, Caterina MJ, Malmberg AB, Rosen TA, Gilbert H, Skinner $K_{\text {, }}$ Raumann BE, Basbaum Al, Julius D: The cloned capsaicin receptor integrates multiple pain-producing stimuli. Neuron 1998, 21:531-543.

80. Olah Z, Szabo T, Karai L, Hough C, Fields RD, Caudle RM, Blumberg PM, ladarola MJ: Ligand-induced dynamic membrane changes and cell deletion conferred by vanilloid receptor 1. J Biol Chem 2001, 276:1102111030.

81. Spraque J, Harrison C, Rowbotham DJ, Smart D, Lambert DG: Temperaturedependent activation of recombinant rat vanilloid VR1 receptors expressed in HEK293 cells by capsaicin and anandamide. Eur J Pharmacol 2001, 423:121-125.

82. De Petrocellis L, Harrison S, Bisogno T, Tognetto M, Brandi I, Smith GD, Creminon C, Davis JB, Geppetti P, Di Marzo V: The vanilloid receptor (VR1)- 
mediated effects of anandamide are potently enhanced by the CAMPdependent protein kinase. J Neurochem 2001, 77:1660-1663.

83. Rathee PK, Distler C, Obreja O, Neuhuber W, Wang GK, Wang SY, Nau C, Kress M: PKA/AKAP/VR-1 module: A common link of Gs-mediated signaling to thermal hyperalgesia. J Neurosci 2002, 22:4740-4745.

84. Vlachova V, Teisinger J, Susankova K, Lyfenko A, Ettrich R, Vyklicky L: Functional role of $\mathrm{C}$-terminal cytoplasmic tail of rat vanilloid receptor 1. Neurosci 2003, 23:1340-1350.

85. Bhave G, Hu HJ, Glauner KS, Zhu W, Wang H, Brasier DJ, Oxford GS: Gereau RWt: Protein kinase $C$ phosphorylation sensitizes but does not activate the capsaicin receptor transient receptor potential vanilloid 1 (TRPV1). Proc Natl Acad Sci U S A 2003, 100:12480-12485.

86. Zhang X, Du XN, Zhang GH, Jia ZF, Chen XJ, Huang DY, Liu BY, Zhang HL: Agonist-dependent potentiation of vanilloid receptor transient receptor potential vanilloid type 1 function by stilbene derivatives. Mol Pharmacol 2012, 81:689-700.

87. Ohta T, Imagawa $\mathrm{T}$, Ito $\mathrm{S}$ : Novel agonistic action of mustard oil on recombinant and endogenous porcine transient receptor potential V1 (pTRPV1) channels. Biochem Pharmacol 2007, 73:1646-1656.

88. Czaja K, Burns GA, Ritter RC: Capsaicin-induced neuronal death and proliferation of the primary sensory neurons located in the nodose ganglia of adult rats. Neuroscience 2008, 154:621-630.

89. Olah Z, Karai L, ladarola MJ: Protein kinase C(alpha) is required for vanilloid receptor 1 activation. Evidence for multiple signaling pathways. J Biol Chem 2002, 277:35752-35759.

90. Wang Y, Kedei N, Wang M, Wang QJ, Huppler AR, Toth A, Tran R, Blumberg PM: Interaction between protein kinase $\mathrm{Cmu}$ and the vanilloid receptor type 1.J Biol Chem 2004, 279:53674-53682.

91. Jung J, Shin JS, Lee SY, Hwang SW, Koo J, Cho H, Oh U: Phosphorylation of vanilloid receptor 1 by Ca2+/calmodulin-dependent kinase II regulates its vanilloid binding. J Biol Chem 2004, 279:7048-7054.

92. Zhou HY, Zhang HM, Chen SR, Pan HL: Increased nociceptive input rapidly modulates spinal GABAergic transmission through endogenously released glutamate. J Neurophysiol 2007, 97:871-882.

93. Docherty RJ, Yeats JC, Bevan S, Boddeke HW: Inhibition of calcineurin inhibits the desensitization of capsaicin-evoked currents in cultured dorsal root ganglion neurones from adult rats. Pflugers Arch 1996, 431:828-837.

94. Koplas PA, Rosenberg RL, Oxford GS: The role of calcium in the desensitization of capsaicin responses in rat dorsal root ganglion neurons. J Neurosci 1997, 17:3525-3537.

95. Prescott ED, Julius D: A modular PIP2 binding site as a determinant of capsaicin receptor sensitivity. Science 2003, 300:1284-1288.

96. Liu B, Zhang C, Qin F: Functional recovery from desensitization of vanilloid receptor TRPV1 requires resynthesis of phosphatidylinositol 4,5bisphosphate. J Neurosci 2005, 25:4835-4843.

97. Stein AT, Ufret-Vincenty CA, Hua L, Santana LF, Gordon SE: Phosphoinositide 3-kinase binds to TRPV1 and mediates NGF-stimulated TRPV1 trafficking to the plasma membrane. J Gen Physiol 2006, 128:509522.

98. Ufret-Vincenty CA, Klein RM, Hua L, Anqueyra J, Gordon SE: Localization of the PIP2 sensor of TRPV1 ion channels. J Biol Chem 2011, 286:9688-9698.

99. Yao J, Qin F: Interaction with phosphoinositides confers adaptation onto the TRPV1 pain receptor. PLOS Biol 2009, 7:e46.

100. Levitan I, Fang Y, Rosenhouse-Dantsker A, Romanenko V: Cholesterol and ion channels. Subcell Biochem 2010, 51:509-549.

101. Levitan I, Christian AE, Tulenko TN, Rothblat GH: Membrane cholesterol content modulates activation of volume-regulated anion current in bovine endothelial cells. J Gen Physiol 2000, 115:405-416.

102. Levitan I: Cholesterol and Kir channels. IUBMB Life 2009, 61:781-790.

103. Liu M, Huang W, Wu D, Priestley JV: TRPV1, but not P2X, requires cholesterol for its function and membrane expression in rat nociceptors. Eur J Neurosci 2006, 24:1-6.

104. Szoke E, Borzsei R, Toth DM, Lengl O, Helyes Z, Sandor Z, Szolcsanyi J: Effect of lipid raft disruption on TRPV1 receptor activation of trigeminal sensory neurons and transfected cell line. Eur J Pharmacol 2010, 628:6774.

105. Santha P, Oszlacs O, Dux M, Dobos I, Jancso G: Inhibition of glucosylceramide synthase reversibly decreases the capsaicin-induced activation and TRPV1 expression of cultured dorsal root ganglion neurons. Pain 2010, 150:103-112.
106. Numazaki M, Tominaga T, Takeuchi K, Murayama N, Toyooka H, Tominaga M: Structural determinant of TRPV1 desensitization interacts with calmodulin. Proc Natl Acad Sci U S A 2003, 100:8002-8006.

107. Rosenbaum T, Gordon-Shaag A, Munari M, Gordon SE: Ca2+/calmodulin modulates TRPV1 activation by capsaicin. J Gen Physiol 2004, 123:53-62.

108. Vyklicky L, Novakova-Tousova K, Benedikt J, Samad A, Touska F, Vlachova V: Calcium-dependent desensitization of vanilloid receptor TRPV1: a mechanism possibly involved in analgesia induced by topical application of capsaicin. Physiol Res 2008, 57(Suppl 3):S59-68.

109. Tominaga M, Wada M, Masu M: Potentiation of capsaicin receptor activity by metabotropic ATP receptors as a possible mechanism for ATP-evoked pain and hyperalgesia. Proc Natl Acad Sci U S A 2001, 98:6951-6956.

110. Vellani V, Mapplebeck S, Moriondo A, Davis JB, McNaughton PA: Protein kinase $\mathrm{C}$ activation potentiates gating of the vanilloid receptor VR1 by capsaicin, protons, heat and anandamide. J Physiol 2001, 534:813-825.

111. Farkas B, Bonnekoh B, Mahrle G: Repeated treatment with dithranol induces a tolerance reaction in keratinocytes in vitro. Arch Dermatol Res 1991, 283:337-341

112. Susankova K, Tousova K, Vyklicky L, Teisinger J, Vlachova V: Reducing and oxidizing agents sensitize heat-activated vanilloid receptor (TRPV1) current. Mol Pharmacol 2006, 70:383-394.

113. Cesare P, Dekker LV, Sardini A, Parker PJ, McNaughton PA: Specific involvement of PKC-epsilon in sensitization of the neuronal response to painful heat. Neuron 1999, 23:617-624.

114. Premkumar LS, Ahern GP: Induction of vanilloid receptor channel activity by protein kinase C. Nature 2000, 408:985-990.

115. Chuang HH, Prescott ED, Kong H, Shields S, Jordt SE, Basbaum Al, Chao MV, Julius D: Bradykinin and nerve growth factor release the capsaicin receptor from Ptdlns(4,5)P2-mediated inhibition. Nature 2001, 411:957962

116. Bhave G, Zhu W, Wang H, Brasier DJ, Oxford GS: Gereau RWt: cAMPdependent protein kinase regulates desensitization of the capsaicin receptor (VR1) by direct phosphorylation. Neuron 2002, 35:721-731.

117. Shin HJ, Gye MH, Chung KH, Yoo BS: Activity of protein kinase C modulates the apoptosis induced by polychlorinated biphenyls in human leukemic HL-60 cells. Toxicol Lett 2002, 135:25-31.

118. Bevan S, Andersson DA: TRP channel antagonists for pain-opportunities beyond TRPV1. Curr Opin Investig Drugs 2009, 10:655-663.

119. Cortright DN, Szallasi A: TRP channels and pain. Curr Pharm Des 2009, 15:1736-1749

120. Stucky CL, Dubin AE, Jeske NA, Malin SA, McKemy DD, Story GM: Roles of transient receptor potential channels in pain. Brain Res Rev 2009, 60:2-23.

121. Fernandes ES, Russell FA, Spina D, McDougall JJ, Graepel R, Gentry C, Staniland AA, Mountford DM, Keeble JE, Malcangio M, et al: A distinct role for transient receptor potential ankyrin 1, in addition to transient receptor potential vanilloid 1 , in tumor necrosis factor alpha-induced inflammatory hyperalgesia and Freund's complete adjuvant-induced monarthritis. Arthritis Rheum 2011, 63:819-829.

122. Fernandes ES, Fernandes MA, Keeble JE: The functions of TRPA1 and TRPV1: moving away from sensory nerves. Br J Pharmacol 2012, 166:510521

123. Alawi $\mathrm{K}$, Keeble J: The paradoxical role of the transient receptor potential vanilloid 1 receptor in inflammation. Pharmacol Ther 2010, 125:181-195.

124. Dux M, Santha P, Jancso G: The role of chemosensitive afferent nerves and TRP ion channels in the pathomechanism of headaches. Pflugers Arch 2012, 464:239-248.

125. Jin K, Xie L, Kim SH, Parmentier-Batteur S, Sun Y, Mao XO, Childs J, Greenberg DA: Defective adult neurogenesis in CB1 cannabinoid receptor knockout mice. Mol Pharmacol 2004, 66:204-208.

126. Jancso-Gabor A, Szolcsanyi J, Jancso N: Stimulation and desensitization of the hypothalamic heat-sensitive structures by capsaicin in rats. J Physiol 1970, 208:449-459.

127. Jancso G, Wollemann M: The effect of capsaicin on the adenylate cyclase activity of rat brain. Brain Res 1977, 123:323-329.

128. Dib B: Effects of intracerebroventricular capsaicin on thermoregulatory behavior in the rat. Pharmacol Biochem Behav 1982, 16:23-27.

129. Steiner AA, Turek VF, Almeida MC, Burmeister JJ, Oliveira DL, Roberts JL, Bannon AW, Norman MH, Louis JC, Treanor J, et al: Nonthermal activation of transient receptor potential vanilloid-1 channels in abdominal viscera tonically inhibits autonomic cold-defense effectors. J Neurosci 2007, $27: 7459-7468$ 
130. Gavva NR, Bannon AW, Hovland DN Jr, Lehto SG, Klionsky L, Surapaneni S, Immke DC, Henley C, Arik L, Bak A, et al: Repeated administration of vanilloid receptor TRPV1 antagonists attenuates hyperthermia elicited by TRPV1 blockade. J Pharmacol Exp Ther 2007, 323:128-137.

131. Tamayo N, Liao H, Stec MM, Wang X, Chakrabarti P, Retz D, Doherty EM, Surapaneni S, Tamir R, Bannon AW, et al: Design and synthesis of peripherally restricted transient receptor potential vanilloid 1 (TRPV1) antagonists. J Med Chem 2008, 51:2744-2757.

132. Inoue K, Koizumi S, Fuziwara S, Denda S, Denda M: Functional vanilloid receptors in cultured normal human epidermal keratinocytes. Biochem Biophys Res Commun 2002, 291:124-129.

133. Kim SJ, Lee SA, Yun SJ, Kim JK, Park JS, Jeong HS, Lee JH, Moon SJ, Won YH: Expression of vanilloid receptor 1 in cultured fibroblast. Exp Dermatol 2006, 15:362-367.

134. Grone A, Fonfara S, Baumgartner W: Cell type-dependent cytokine expression after canine distemper virus infection. Viral Immunol 2002, 15:493-505.

135. Southall MD, Li T, Gharibova LS, Pei Y, Nicol GD, Travers JB: Activation of epidermal vanilloid receptor-1 induces release of proinflammatory mediators in human keratinocytes. J Pharmacol Exp Ther 2003, 304:217222.

136. Saunders Cl, Kunde DA, Crawford A, Geraghty DP: Expression of transient receptor potential vanilloid 1 (TRPV1) and 2 (TRPV2) in human peripheral blood. Mol Immunol 2007, 44:1429-1435.

137. Basu S, Srivastava P: Immunological role of neuronal receptor vanilloid receptor 1 expressed on dendritic cells. Proc Natl Acad Sci U S A 2005, 102:5120-5125.

138. Geppetti P, Nassini R, Materazzi S, Benemei S: The concept of neurogenic inflammation. BJU Int 2008, 101(Suppl 3):2-6.

139. Earley S, Gonzales AL, Crnich R: Endothelium-dependent cerebral artery dilation mediated by TRPA 1 and $\mathrm{Ca} 2+-$ Activated $\mathrm{K}+$ channels. Circ Res 2009, 104:987-994.

140. Kark T, Bagi Z, Lizanecz E, Pasztor ET, Erdei N, Czikora A, Papp Z, Edes I, Porszasz R, Toth A: Tissue-specific regulation of microvascular diameter: opposite functional roles of neuronal and smooth muscle located vanilloid receptor-1. Mol Pharmacol 2008, 73:1405-1412.

141. Luo D, Zhang YW, Peng WJ, Peng J, Chen QQ, Li D, Deng HW, Li YJ: Transient receptor potential vanilloid 1-mediated expression and secretion of endothelial cell-derived calcitonin gene-related peptide. Regul Pept 2008, 150:66-72.

142. Brain SD, Williams TJ, Tippins JR, Morris HR, Maclntyre I: Calcitonin generelated peptide is a potent vasodilator. Nature 1985, 313:54-56.

143. Zygmunt PM, Petersson J, Andersson DA, Chuang H, Sorgard M, Di Marzo V, Julius D, Hogestatt ED: Vanilloid receptors on sensory nerves mediate the vasodilator action of anandamide. Nature 1999, 400:452-457.

144. Keeble JE, Brain SD: Capsaicin-induced vasoconstriction in the mouse knee joint: a study using TRPV1 knockout mice. Neurosci Lett 2006, 401:55-58.

145. Cavanaugh DJ, Chesler AT, Jackson AC, Sigal YM, Yamanaka H, Grant R, O'Donnell D, Nicoll RA, Shah NM, Julius D, Basbaum Al: Trpv1 reporter mice reveal highly restricted brain distribution and functional expression in arteriolar smooth muscle cells. J Neurosci 2011, 31:5067-5077.

146. Dux M, Santha P, Jancso G: Capsaicin-sensitive neurogenic sensory vasodilatation in the dura mater of the rat. J Physiol 2003, 552:859-867.

147. Wang YX, Wang J, Wang C, Liu J, Shi LP, Xu M: Functional expression of transient receptor potential vanilloid-related channels in chronically hypoxic human pulmonary arterial smooth muscle cells. J Membr Biol 2008, 223:151-159.

148. Hwang JT, Park IJ, Shin JI, Lee YK, Lee SK, Baik HW, Ha J, Park OJ: Genistein, EGCG, and capsaicin inhibit adipocyte differentiation process via activating AMP-activated protein kinase. Biochem Biophys Res Commun 2005, 338:694-699.

149. Hsu CL, Yen GC: Effects of capsaicin on induction of apoptosis and inhibition of adipogenesis in 3T3-L1 cells. J Agric Food Chem 2007, 55:1730-1736

150. Zhang LL, Yan Liu D, Ma LQ, Luo ZD, Cao TB, Zhong J, Yan ZC, Wang LJ, Zhao ZG, Zhu SJ, et al: Activation of transient receptor potential vanilloid type-1 channel prevents adipogenesis and obesity. Circ Res 2007, 100:1063-1070.

151. Ohnuki K, Haramizu S, Oki K, Watanabe T, Yazawa S, Fushiki T: Administration of capsiate, a non-pungent capsaicin analog, promotes energy metabolism and suppresses body fat accumulation in mice. Biosci Biotechnol Biochem 2001, 65:2735-2740.

152. Kang JH, Goto T, Han IS, Kawada T, Kim YM, Yu R: Dietary capsaicin reduces obesity-induced insulin resistance and hepatic steatosis in obese mice fed a high-fat diet. Obesity (Silver Spring) 2010, 18:780-787.

153. Romanovsky AA, Almeida MC, Garami A, Steiner AA, Norman MH, Morrison SF, Nakamura K, Burmeister JJ, Nucci TB: The transient receptor potential vanilloid-1 channel in thermoregulation: a thermosensor it is not. Pharmacol Rev 2009, 61:228-261.

154. Caterina MJ: Transient receptor potential ion channels as participants in thermosensation and thermoregulation. Am J Physiol Regul Integr Comp Physiol 2007, 292:R64-76.

155. Masamoto Y, Kawabata F, Fushiki T: Intragastric administration of TRPV1, TRPV3, TRPM8, and TRPA1 agonists modulates autonomic thermoregulation in different manners in mice. Biosci Biotechnol Biochem 2009, 73:1021-1027.

156. Kawabata F, Inoue N, Masamoto Y, Matsumura S, Kimura W, Kadowaki M, Higashi T, Tominaga M, Inoue K, Fushiki T: Non-pungent capsaicin analogs (capsinoids) increase metabolic rate and enhance thermogenesis via gastrointestinal TRPV1 in mice. Biosci Biotechnol Biochem 2009, 73:26902697.

157. Toth DM, Szoke E, Bolcskei K, Kvell K, Bender B, Bosze Z, Szolcsanyi J, Sandor $Z$ : Nociception, neurogenic inflammation and thermoregulation in TRPV1 knockdown transgenic mice. Cell Mol Life Sci 2011, 68:2589-2601.

158. Bodo E, Biro T, Telek A, Czifra G, Griger Z, Toth Bl, Mescalchin A, Ito T, Bettermann A, Kovacs L, Paus R: A hot new twist to hair biology: involvement of vanilloid receptor-1 (VR1/TRPV1) signaling in human hair growth control. Am J Pathol 2005, 166:985-998.

159. White JP, Urban L, Nagy I: TRPV1 function in health and disease. Curr Pharm Biotechnol 2011, 12:130-144.

160. Cortright DN, Krause JE, Broom DC: TRP channels and pain. Biochim Biophys Acta 2007, 1772:978-988.

161. Gunthorpe MJ, Szallasi A: Peripheral TRPV1 receptors as targets for drug development: new molecules and mechanisms. Curr Pharm Des 2008, 14:32-41.

162. Toth A, Boczan J, Kedei N, Lizanecz E, Bagi Z, Papp Z, Edes I, Csiba L, Blumberg PM: Expression and distribution of vanilloid receptor 1 (TRPV1) in the adult rat brain. Brain Res Mol Brain Res 2005, 135:162-168.

163. Yiangou Y, Facer $P$, Dyer NH, Chan CL, Knowles C, Williams NS, Anand P: Vanilloid receptor 1 immunoreactivity in inflamed human bowel. Lancet 2001, 357:1338-1339.

164. Chan CL, Facer P, Davis JB, Smith GD, Egerton J, Bountra C, Williams NS, Anand $P$ : Sensory fibres expressing capsaicin receptor TRPV1 in patients with rectal hypersensitivity and faecal urgency. Lancet 2003, 361:385-391.

165. Welch JM, Simon SA, Reinhart PH: The activation mechanism of rat vanilloid receptor 1 by capsaicin involves the pore domain and differs from the activation by either acid or heat. Proc Natl Acad Sci U S A 2000, 97:13889-13894.

166. Kuzhikandathil EV, Wang H, Szabo T, Morozova N, Blumberg PM, Oxford GS: Functional analysis of capsaicin receptor (vanilloid receptor subtype 1) multimerization and agonist responsiveness using a dominant negative mutation. J Neurosci 2001, 21:8697-8706.

167. Grandl J, Kim SE, Uzzell V, Bursulaya B, Petrus M, Bandell M, Patapoutian A: Temperature-induced opening of TRPV1 ion channel is stabilized by the pore domain. Nat Neurosci 2010, 13:708-714.

168. Jordt SE, Julius D: Molecular basis for species-specific sensitivity to "hot" chili peppers. Cell 2002, 108:421-430.

169. Ho KW, Ward NJ, Calkins DJ: TRPV1: a stress response protein in the central nervous system. Am J Neurodegener Dis 2012, 1:1-14.

170. Chou MZ, Mtui T, Gao YD, Kohler M, Middleton RE: Resiniferatoxin binds to the capsaicin receptor (TRPV1) near the extracellular side of the S4 transmembrane domain. Biochemistry 2004, 43:2501-2511.

171. Gavva NR, Klionsky L, Qu Y, Shi L, Tamir R, Edenson S, Zhang TJ, Viswanadhan VN, Toth A, Pearce LV, et al: Molecular determinants of vanilloid sensitivity in TRPV1. J Biol Chem 2004, 279:20283-20295.

172. Fernandez-Ballester G, Ferrer-Montiel A: Molecular modeling of the fulllength human TRPV1 channel in closed and desensitized states. J Membr Biol 2008, 223:161-172.

173. Johnson DM, Garrett EM, Rutter R, Bonnert TP, Gao YD, Middleton RE, Sutton KG: Functional mapping of the transient receptor potential vanilloid 1 intracellular binding site. Mol Pharmacol 2006, 70:1005-1012. 
174. Numazaki M, Tominaga T, Toyooka H, Tominaga M: Direct phosphorylation of capsaicin receptor VR1 by protein kinase Cepsilon and identification of two target serine residues. J Biol Chem 2002, 277:13375-13378.

175. Susankova K, Ettrich R, Vyklicky L, Teisinger J, Vlachova V: Contribution of the putative inner-pore region to the gating of the transient receptor potential vanilloid subtype 1 channel (TRPV1). J Neurosci 2007, 27:75787585

176. Mohapatra DP, Wang SY, Wang GK, Nau C: A tyrosine residue in TM6 of the Vanilloid Receptor TRPV1 involved in desensitization and calcium permeability of capsaicin-activated currents. Mol Cell Neurosci 2003, 23:314-324.

177. Myers BR, Bohlen CJ, Julius D: A yeast genetic screen reveals a critical role for the pore helix domain in TRP channel gating. Neuron 2008, 58:362373

178. Salazar H, Jara-Oseguera A, Hernandez-Garcia E, Llorente I, Arias O II, Soriano-Garcia M, Islas LD, Rosenbaum T: Structural determinants of gating in the TRPV1 channel. Nat Struct Mol Biol 2009, 16:704-710.

179. Boukalova S, Marsakova L, Teisinger J, Vlachova V: Conserved residues within the putative S4-S5 region serve distinct functions among thermosensitive vanilloid transient receptor potential (TRPV) channels. $J$ Biol Chem 2010, 285:41455-41462.

180. Lee JH, Lee Y, Ryu H, Kang DW, Lee J, Lazar J, Pearce LV, Pavlyukovets VA, Blumberg PM, Choi S: Structural insights into transient receptor potential vanilloid type 1 (TRPV1) from homology modeling, flexible docking, and mutational studies. J Comput Aided Mol Des 2011, 25:317-327.

181. Bautista DM, Movahed P, Hinman A, Axelsson HE, Sterner O, Hogestatt ED, Julius D, Jordt SE, Zygmunt PM: Pungent products from garlic activate the sensory ion channel TRPA1. Proc Natl Acad Sci U S A 2005, 102:1224812252.

182. Hinman A, Chuang HH, Bautista DM, Julius D: TRP channel activation by reversible covalent modification. Proc Natl Acad Sci U S A 2006, 103:19564-19568.

183. Bandell M, Story GM, Hwang SW, Viswanath V, Eid SR, Petrus MJ, Earley TJ, Patapoutian A: Noxious cold ion channel TRPA1 is activated by pungent compounds and bradykinin. Neuron 2004, 41:849-857.

184. Macpherson $\sqcup$, Dubin AE, Evans MJ, Marr F, Schultz PG, Cravatt BF, Patapoutian A: Noxious compounds activate TRPA1 ion channels through covalent modification of cysteines. Nature 2007, 445:541-545.

185. Rosenbaum T, Castanares DT, Lopez-Valdes HE, Hiriart M: Nerve growth factor increases L-type calcium current in pancreatic beta cells in culture. J Membr Biol 2002, 186:177-184.

186. Salazar H, Llorente I, Jara-Oseguera A, Garcia-Villegas R, Munari M, Gordon $\mathrm{SE}$, Islas LD, Rosenbaum T: A single N-terminal cysteine in TRPV1 determines activation by pungent compounds from onion and garlic. Nat Neurosci 2008, 11:255-261.

187. Latorre R, Zaelzer C, Brauchi S: Structure-functional intimacies of transient receptor potential channels. Q Rev Biophys 2009, 42:201-246.

188. Brauchi S, Orta G, Salazar M, Rosenmann E, Latorre R: A hot-sensing cold receptor: C-terminal domain determines thermosensation in transient receptor potential channels. J Neurosci 2006, 26:4835-4840.

189. Yao J, Liu B, Qin F: Modular thermal sensors in temperature-gated transient receptor potential (TRP) channels. Proc Natl Acad Sci U S A 2011, 108:11109-11114.

190. Cui Y, Yang F, Cao X, Yarov-Yarovoy V, Wang K, Zheng J: Selective disruption of high sensitivity heat activation but not capsaicin activation of TRPV1 channels by pore turret mutations. J Gen Physiol 2012, 139:273283

191. Brauchi S, Orta G, Mascayano C, Salazar M, Raddatz N, Urbina H, Rosenmann E, Gonzalez-Nilo F, Latorre R: Dissection of the components for PIP2 activation and thermosensation in TRP channels. Proc Natl Acad Sci U S A 2007, 104:10246-10251.

192. Ryu S, Liu B, Yao J, Fu Q, Qin F: Uncoupling proton activation of vanilloid receptor TRPV1. J Neurosci 2007, 27:12797-12807.

193. Sutton KG, Garrett EM, Rutter AR, Bonnert TP, Jarolimek W, Seabrook GR: Functional characterisation of the S512Y mutant vanilloid human TRPV1 receptor. Br J Pharmacol 2005, 146:702-711.

194. Grimm C, Aneiros E, de Groot M: Dissecting TRPV1: lessons to be learned? Channels (Austin) 2011, 5:201-204.

195. Aneiros E, Cao L, Papakosta M, Stevens EB, Phillips S, Grimm C: The biophysical and molecular basis of TRPV1 proton gating. EMBO J 2011, 30:994-1002.
196. Voets T, Owsianik G, Janssens A, Talavera K, Nilius B: TRPM8 voltage sensor mutants reveal a mechanism for integrating thermal and chemical stimuli. Nat Chem Biol 2007, 3:174-182.

197. Garcia-Martinez C, Morenilla-Palao C, Planells-Cases R, Merino JM, FerrerMontiel A: Identification of an aspartic residue in the P-loop of the vanilloid receptor that modulates pore properties. J Biol Chem 2000 275:32552-32558.

198. Bohlen CJ, Priel A, Zhou S, King D, Siemens J, Julius D: A bivalent tarantula toxin activates the capsaicin receptor, TRPV1, by targeting the outer pore domain. Cell 2010, 141:834-845.

199. Siemens J, Zhou S, Piskorowski R, Nikai T, Lumpkin EA, Basbaum Al, King D, Julius D: Spider toxins activate the capsaicin receptor to produce inflammatory pain. Nature 2006, 444:208-212

200. Kitaguchi T, Swartz KJ: An inhibitor of TRPV1 channels isolated from funnel Web spider venom. Biochemistry 2005, 44:15544-15549.

201. Grycova L, Lansky Z, Friedlova E, Obsilova V, Janouskova H, Obsil T, Teisinger $\mathrm{J}$ : Ionic interactions are essential for TRPV1 C-terminus binding to calmodulin. Biochem Biophys Res Commun 2008, 375:680-683.

202. Grycova L, Lansky Z, Friedlova E, Vlachova V, Kubala M, Obsilova V, Obsil T, Teisinger J: ATP binding site on the C-terminus of the vanilloid receptor. Arch Biochem Biophys 2007, 465:389-398.

203. Kwon Y, Hofmann T, Montell C: Integration of phosphoinositide- and calmodulin-mediated regulation of TRPC6. Mol Cell 2007, 25:491-503.

204. Zhu MX: Multiple roles of calmodulin and other $\mathrm{Ca}(2+)$-binding proteins in the functional regulation of TRP channels. Pflugers Arch 2005, 451:105115.

205. Kwak J, Wang MH, Hwang SW, Kim TY, Lee SY, Oh U: Intracellular ATP increases capsaicin-activated channel activity by interacting with nucleotide-binding domains. J Neurosci 2000, 20:8298-8304.

206. Grycova L, Holendova B, Bumba L, Bily J, Jirku M, Lansky Z, Teisinger J: Integrative binding sites within intracellular termini of TRPV1 receptor. PLOS ONE 2012, 7:e48437.

207. Tousova K, Susankova K, Teisinger J, Vyklicky L, Vlachova V: Oxidizing reagent copper-o-phenanthroline is an open channel blocker of the vanilloid receptor TRPV1. Neuropharmacology 2004, 47:273-285.

208. Picazo-Juarez G, Romero-Suarez S, Nieto-Posadas A, Llorente I, JaraOseguera A, Briggs M, Mclntosh TJ, Simon SA, Ladron-de-Guevara E, Islas $L D$, Rosenbaum $T$ : Identification of a binding motif in the $S 5$ helix that confers cholesterol sensitivity to the TRPV1 ion channel. J Biol Chem 2011, 286:24966-24976.

209. Numazaki M, Tominaga M: Nociception and TRP Channels. Curr Drug Targets CNS Neurol Disord 2004, 3:479-485.

210. Mohapatra DP, Nau C: Desensitization of capsaicin-activated currents in the vanilloid receptor TRPV1 is decreased by the cyclic AMP-dependent protein kinase pathway. J Biol Chem 2003, 278:50080-50090.

211. Zhang $X$, Huang J, McNaughton PA: NGF rapidly increases membrane expression of TRPV1 heat-gated ion channels. EMBO J 2005, 24:42114223.

212. Wirkner $K$, Hognestad $H$, Jahnel $R$, Hucho F, Illes P: Characterization of rat transient receptor potential vanilloid 1 receptors lacking the $\mathrm{N}$ glycosylation site N604. Neuroreport 2005, 16:997-1001.

213. Pecze L, Winter Z, Josvay K, Otvos F, Kolozsi C, Vizler C, Budai D, Letoha T, Dombi G, Szakonyi G, Olah Z: Divalent heavy metal cations block the TRPV1 Ca(2+) channel. Bio/ Trace Elem Res 2012, 151:451-461.

214. Garcia-Sanz N, Fernandez-Carvajal A, Morenilla-Palao C, Planells-Cases R, Fajardo-Sanchez E, Fernandez-Ballester G, Ferrer-Montiel A: Identification of a tetramerization domain in the $\mathrm{C}$ terminus of the vanilloid receptor. $J$ Neurosci 2004, 24:5307-5314.

doi:10.1186/1744-8069-9-30

Cite this article as: Winter et al:: Functionally important amino acid residues in the transient receptor potential vanilloid 1 (TRPV1) ion channel - an overview of the current mutational data. Molecular Pain 2013 9:30. 